UNIVERSIDADE DE SÃO PAULO

FACULDADE DE FILOSOFIA, LETRAS E CIÊNCIAS HUMANAS

DEPARTAMENTO DE LETRAS CLÁSSICAS E VERNÁCULAS

ÁREA DE ESTUDOS COMPARADOS DE LITERATURAS DE LÍNGUA PORTUGUESA

FERNANDA RODRIGUES DE MIRANDA

OS CAMINHOS LITERÁRIOS DE CAROLINA MARIA DE JESUS: EXPERIÊNCIA MARGINAL E CONSTRUÇÃO ESTÉTICA

SÃO PAULO, 2013.

(Versão Corrigida) 
UNIVERSIDADE DE SÃO PAULO

FACULDADE DE FILOSOFIA, LETRAS E CIÊNCIAS HUMANAS

DEPARTAMENTO DE LETRAS CLÁSSICAS E VERNÁCULAS

ÁREA DE ESTUDOS COMPARADOS DE LITERATURAS DE LÍNGUA PORTUGUESA

\title{
OS CAMINHOS LITERÁRIOS DE CAROLINA MARIA DE JESUS: EXPERIÊNCIA MARGINAL E CONSTRUÇÃO ESTÉTICA
}

\begin{abstract}
Fernanda Rodrigues de Miranda
Dissertação apresentada ao Programa de Pósgraduação em Estudos Comparados de Literaturas de Língua Portuguesa do Departamento de Letras Clássicas e Vernáculas da Faculdade de Filosofia, Letras e Ciências Humanas da Universidade de São Paulo - USP, com vistas à obtenção do título de Mestre em Letras.
\end{abstract}

Orientador: Profo Dr. Mário César Lugarinho

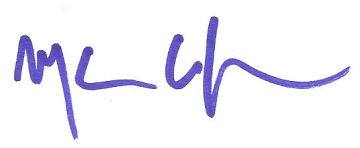

São Paulo, 2013.

(Versão Corrigida) 
Autorizo a reprodução e divulgação total ou parcial deste trabalho, por qualquer meio convencional ou eletrônico, para fins de estudo e pesquisa, desde que citada a fonte.

Catalogação na publicação Serviço de biblioteca e documentação

Faculdade de Filosofia, Letras e Ciências Humanas da Universidade de São Paulo.

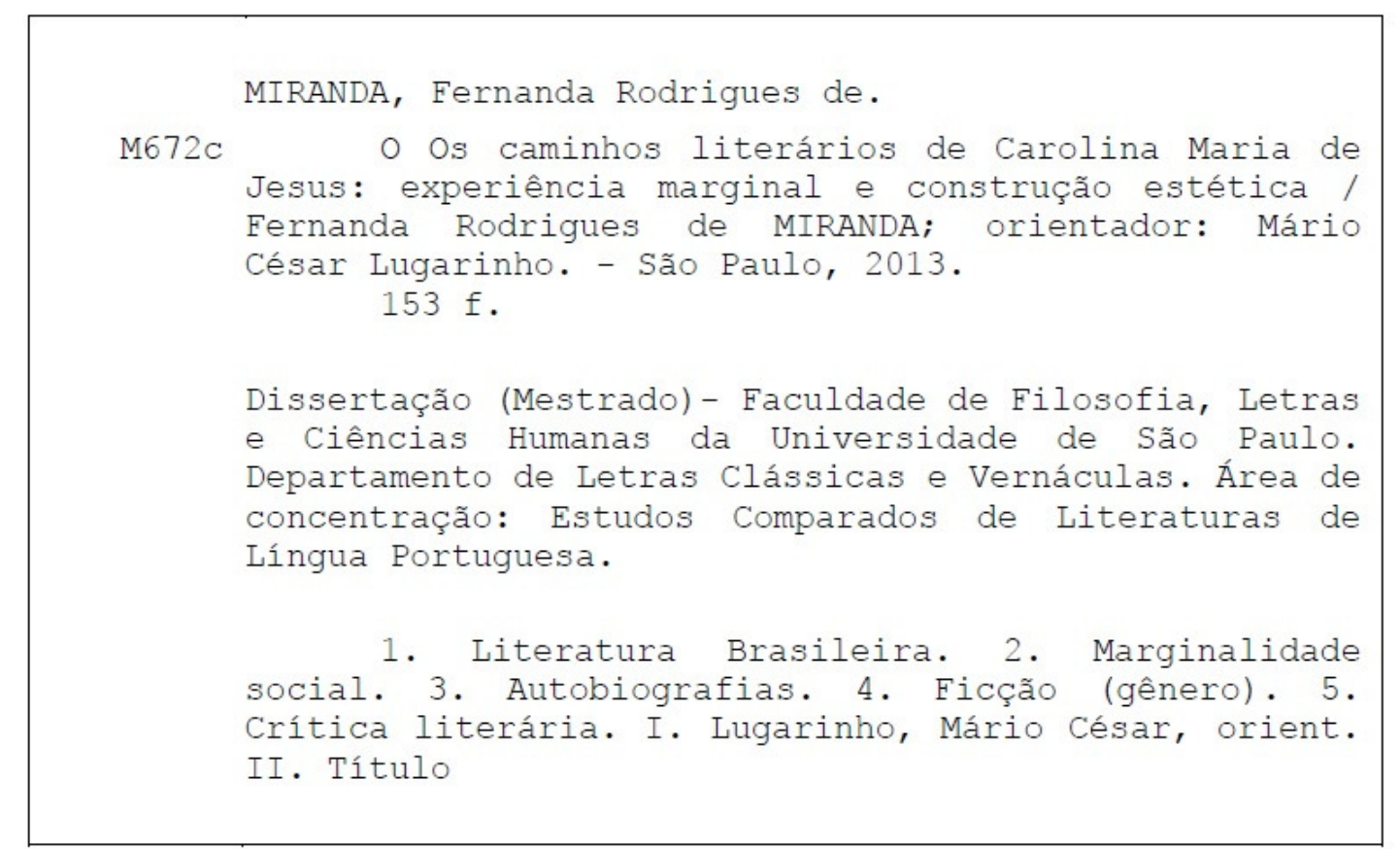


MIRANDA, Fernanda Rodrigues de. Os caminhos literários de Carolina Maria de Jesus: experiência marginal e construção estética. Dissertação apresentada à Faculdade de Filosofia, Letras e Ciências Humanas da Universidade de São Paulo - USP, com vistas à obtenção do título de Mestre em Letras. Área de Estudos Comparados de Literaturas de Língua Portuguesa.

Aprovado em: de de 2013.

\section{BANCA EXAMINADORA}

Examinador: Instituição: Julgamento: Assinatura:

Examinador: Instituição: Julgamento: Assinatura:

Examinador: Instituição: Julgamento: Assinatura:

Examinador: Instituição: Julgamento: Assinatura:

Examinador: Instituição: Julgamento: Assinatura: 
Dedico este trabalho ao Cauê Liberto meu rebento, ainda aqui dentro. 
AGRADECIMENTOS

Ao querido Prof. Dr. Mário César Lugarinho, pela generosidade, orientação, paciência e confiança, desde a Iniciação Científica.

Aos meus pais, Iracema e Orlando, pelo cuidado, pela compreensão, por serem quem são. Aos meus irmãos Amanda e Vinicius, pela vida toda, essa e as outras. Às minhas tias Carmem Lúcia e Maria Gorete, por me inspirarem força e beleza nos caminhos de ser mulher negra nordestina.

À minha avó poeta Maria Anita, pelo amor, pela fortaleza. Ao Coletivo de Mulheres Negras Louva-deusas, pelas aprendizagens. À Flávia Rios e à Viviane Angélica, pela leitura valiosa do projeto. Ao Marciano Ventura, pelos livros raros da Carolina. Aos amigos: Claudia Simões, Daniel Ramos, Daniel Sanches, Dica, Elis Regina, Erenay Martins, Fábio Franco, Isadora Simões, Juliana Costa, Lia Maria, Jairo Souza, Marcos Costa, Raquel Alves, Sérgio Batista, Sinei Sales, Valeria Alves. Aos Carlos, meu companheiro. Porque das incríveis voltas que a roda do Tempo dá é a gente que sabe. Aos professores que compuseram a banca de qualificação, pelo diálogo, críticas e sugestões ao trabalho: Lígia Ferreira e Emerson Inácio. E muito especialmente, ao Profo Dr. Emerson Inácio, por dar mais cor e mais sentido ao curso de Letras e à minha trajetória acadêmica. Às mulheres negras escritoras - inspiração e resistência: Conceição Evaristo, Conceição Lima, Cidinha da Silva, Toni Morrison, Ana Maria Gonçalves, Geni Guimarães, Miriam Alves, Paulina Chiziane e tantas outras. Por me ensinarem a dor e a delícia de ser o que somos. Agradeço à FAPESP, cujo apoio foi fundamental para realização deste trabalho. Aos que mantém minha cabeça viva e sã: "A bença papai! a bença mamãe!" Eu saúdo o povo da rua, o povo das águas, o povo das matas, o povo da terra, o povo do fogo: Axé! A todos, meu muito obrigado. 
Laroyê!

Atirando uma pedra hoje, mata um pássaro ontem.

- Oriki de Exu - 
RESUMO

Análise da obra da escritora Carolina Maria de Jesus (1914-1977), em particular dos livros Quarto de despejo - diário de uma favelada (1960); Casa de Alvenaria - diário de uma exfavelada (1961); Pedaços da fome (1963) e Diário de Bitita (1986). Investigamos aspectos da edição do primeiro livro publicado, analisando a intervenção do editor na construção do estereótipo da "escritora favelada" e o impacto que isso representou na trajetória discursiva da autora. Nosso objetivo foi analisar a internalização da experiência histórica da margem ao campo da dicção da obra literária, superando a introdução da temática, quase inédita na produção literária brasileira, da favela e da sobrevivência urbana marginal. A obra caroliniana, muitas vezes reduzida a mero documento de interesse sociológico, se realiza com contornos estéticos próprios - a escrita é parte fundante de sua constituição subjetiva, pois a autora estetiza a si, cria para si identidade e alteridade, constrói sua subjetividade através da palavra escrita, tornando-se autora, narradora e personagem de si mesma.

PALAVRAS-CHAVE

Carolina Maria de Jesus; Gênero autobiográfico; Autoria marginal; Construção estética. 


\section{ABSTRACT}

Analysis of the work of writer Carolina Maria de Jesus (1914-1977), in particular the books Quarto de despejo - diário de uma favelada (1960); Casa de Alvenaria - diário de uma exfavelada (1961); Pedaços da fome (1963) e Diário de Bitita (1986). We investigate aspects of the edition of the first book published, analyzing editor intervention in the construction of the stereotype of "writer slum" and the impact this discourse represented in the trajectory of the author. Our aim was to analyze the internalization of the historical experience of the margin to the field of the literary diction, surpassing the introduction of the theme, almost unprecedented in Brazilian literary production, the slum and marginal urban survival. The work of Carolina Maria de Jesus often reduced to mere document of sociological interest, is done with own aesthetic contours - writing is a fundamental part of its subjective constitution, aestheticized as the author himself, creates for itself identity and otherness, constructs his subjectivity through written word, becoming author, narrator and character herself.

\section{KEYWORDS}

Carolina Maria de Jesus; Autobiographical genre; Marginal authorship; Aesthetic construction. 
LISTA DE ILUSTRAÇÕES

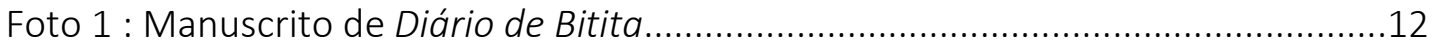

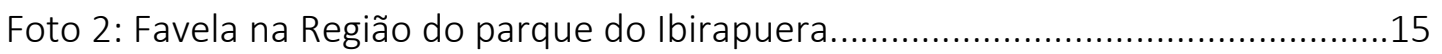




\section{SUMÁRIO}

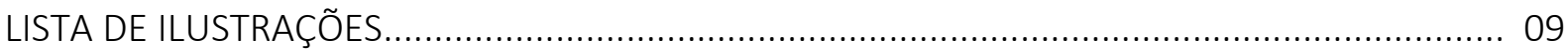

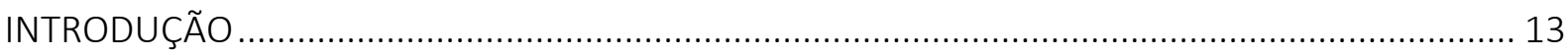

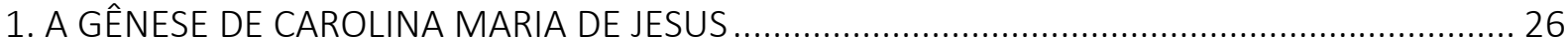

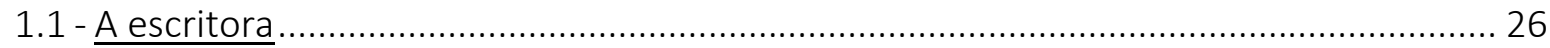

1.2 - Margens do texto: Quarto de despejo e a representação coletiva ................................ 45

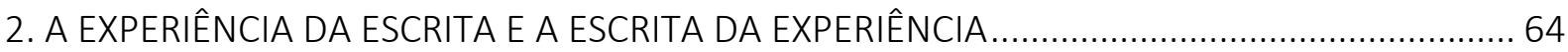

2.1 - Uma mulher negra (e pobre) levanta a opinião pública .............................................. 64

2.2 - Construção estética da experiência: O “ideal de poeta” "............................................... 91

2.3 - A escrita ficcional: Pedaços da Fome - a experiência, a cidade e a escassez ................ 106

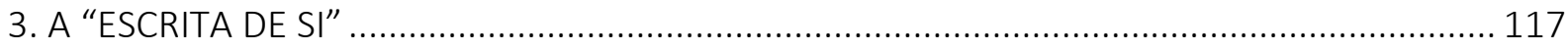

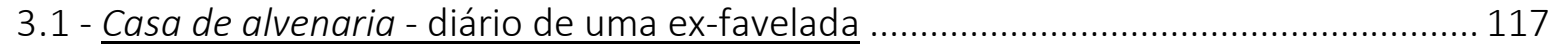

3.2 - “Um brasil para os brasileiros" e A vida de Bitita ............................................................. 136

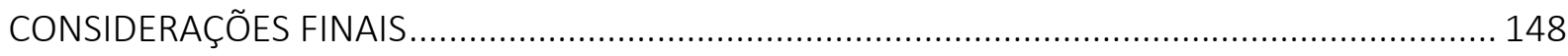

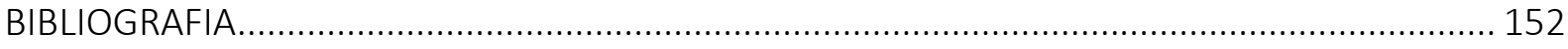

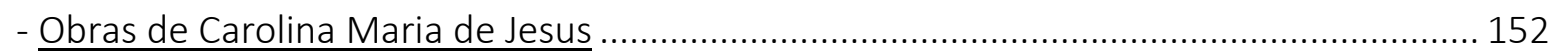

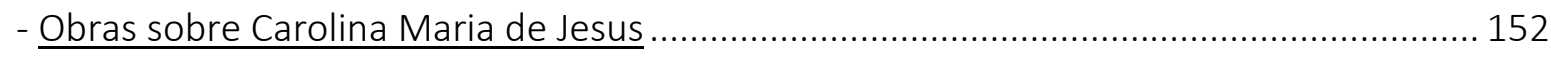

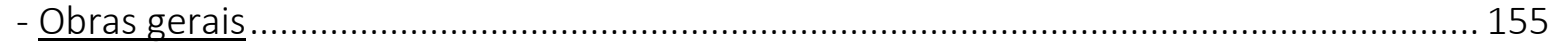




\section{ADVERTÊNCIA}

Todas as citações de Carolina Maria de Jesus transcritas neste trabalho respeitam rigorosamente o padrão ortográfico da autora, tal como impresso na primeira edição de seus livros publicados. 
12

Yuspinacẹão

seu anjo veriho as neu lado

Contenpla as plares no nado

como é lindo o ane facl

ounce se a arte cantor táo fagueira nelo ar. eqquetendo - se ao sol.

Se en fâsse un passarinho Arquitetaria o nosso nin ho No tôpo de uni carruatho. d dánaria - a com Brilhantes Estas jáias eintélantes dis puras gâtos darra eno.

Se nós meus leracos en a entralasse $\because$ depsis en cantasse:

d) Lua cancẽ̃o preferida. pereárrerianós as plourestas - Pijia. Phe proses cono estas Amo-a és minha querida.

Figura 1: Manuscrito de Diário de Bitita. Fonte: Castro \& Machado, 2007, p. 12. 
INTRODUÇÃO

Alimentei, eduquei e amei meus três filhos. Catei papel, revirei lixo. Do papel também tirei meu alimento: a escrita. - Carolina Maria de Jesus

Nos anos 1990, de norte a sul, o refrão era o mesmo em todas as vielas: "Eu só quero é ser feliz! Andar tranquilamente na favela onde eu nasci! E poder me orgulhar e ter a consciência que o pobre tem o seu lugar!" (Cidinho \& Doca, 1994). O funk carioca nascido na Cidade de Deus se espalhava por todas as quebradas, ritmando a insatisfação diante da antiga estrutura social e política que nega à grande maioria dos brasileiros os direitos a uma vida justa. No Rap da Felicidade, se diz: "Nunca vi cartão postal que se destaque uma favela" (Cidinho \& Doca, 1994). Bem antes disso, na década de 1960, quando o país estava prestes a ser governado pelas forças armadas - as fardas detentoras da prerrogativa da violência do estado - o protesto vindo da favela já corria mundo, através das letras transgressoras de Carolina Maria de Jesus, escritora que rompeu com os pressupostos de raça, gênero e classe que sustentam o sistema literário brasileiro.

Entre a batida do funk que brada "Moro na favela e sou muito desrespeitado (...) enquanto os ricos moram numa casa grande e bela, o pobre é humilhado esculachado na favela" (Cidinho \& Doca, 1994) e as palavras de Carolina Maria de Jesus, a mesma revolta:

Levantei. Obedeci a Vera Eunice. Fui buscar água. Fiz o café. Avisei as crianças que
não tinha pão. Que tomassem café simples e comesse carne com farinha. Eu estava
indisposta, resolvi benzer-me. Abri a boca duas vezes, certifiquei-me que estava com
mau olhado. A indisposição desapareceu sai e fui ao seu Manoel levar umas latas
para vender. Tudo quanto eu encontro no lixo eu cato para vender. Deu 13
cruzeiros. Fiquei pensando que precisava comprar pão, sabão e leite para a Vera
Eunice. E os 13 cruzeiros não dava! Cheguei em casa, aliás no meu barracão,
nervosa e exausta. Pensei na vida atribulada que eu levo. Cato papel, lavo roupa
para dois jovens, permaneço na rua o dia todo. E estou sempre em falta. A Vera não
tem sapatos. E ela não gosta de andar descalça (Jesus, 1960, p. 13-14).

Mas os sentidos de pertencimento ao espaço da favela são bem distintos. Toda a luta de Carolina Maria de Jesus - e de outros sujeitos cujas histórias são narradas por ela - era para sair da favela, espaço que violentava sua dignidade. Vitoriosa, ela conseguiu, através da publicação de seu livro, realizar tal desejo. Não havia, absolutamente, na favela do Canindé 
onde a autora viveu a ideia de pertença a uma comunidade, muito forte nos discursos mais contemporâneos acerca da vivência nas periferias, com destaque para o Rap, cujos princípios abrangem a crítica feroz ao sistema social opressor, desigual e violento:

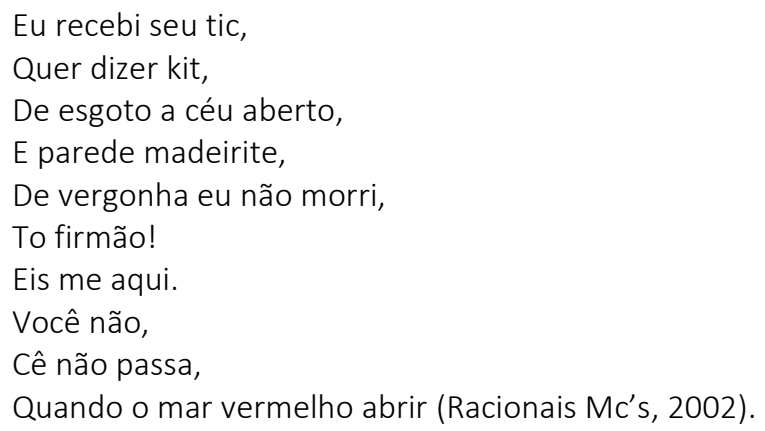

Mas do ponto de vista dos que vivem e querem permanecer vivendo na sua comunidade:

O dinheiro tira um homem da miséria,

Mas não pode arrancar,

De dentro dele

A favela (Racionais Mc's, 2002).

A favela do Canindé ${ }^{1}$ estava literalmente no meio do desenvolvimentismo e das ideias de progresso efervescentes na década de 1950. Sua origem está ligada às comemorações do IV Centenário da cidade, que teve a construção do Parque do Ibirapuera como um de seus principais marcos:

Em documento burocrático, datado de outubro de 1952, a Comissão do IV Centenário toma conhecimento através de relatório das providências que vinham sendo tomadas no sentido de 'reaver inteiramente livre' o espaço destinado à construção do parque. A liberação constituiu-se basicamente da remoção dos

\footnotetext{
${ }^{1}$ A assistente social Marta Teresinha Godinho, diversas vezes citada em Quarto de despejo, é autora de um dos primeiros estudos sobre favelas paulistanas. Em 1955 ela recolheu dados, até então dispersos, sobre o problema na capital para o seu trabalho de conclusão de curso de Serviço Social. De acordo com os dados de Godinho, o estímulo oficial da Prefeitura de São Paulo está presente em quase todos os processos iniciais de surgimento de favelas no município. Segundo ela, a Favela do Canindé "começou em 1948 Junto a Rua Antônio de Barros, num terreno dos irmãos $X$, formou-se uma favela à revelia dos proprietários que, tão logo tiveram conhecimento, requereram despejo policial. Aquelas pessoas então desalojadas foram reclamar no Gabinete do Prefeito [Paulo Lauro], onde receberam um memorando para usarem o terreno da Prefeitura, no Canindé. Para alguns, a Prefeitura forneceu também caminhão para o transporte do barraco. Iniciou-se, então, a "Favela do Canindé" com 99 famílias. Como a área lá era grande, muitas outras pessoas depois, com o correr do tempo, mediante o memorando de autorização do gabinete do senhor Prefeito, foram para lá. Como não havia água e não podiam cavar poços, devido à proximidade do rio Tietê, a Prefeitura mandou instalar uma caixa d'água que abastecesse toda a favela" (Godinho, 1955, p. 10-17. In: Paulino, 2007, p. 80-81). No livro Cinderela Negra: a saga de Carolina Maria de Jesus (Meihy \& Levine, 1994), registra-se seu depoimento sobre a favela onde viveu Carolina: "Conheci Carolina de Jesus na favela do Canindé. Trabalhando como assistente social para a prefeitura do município, minha função era preparar os moradores para uma remoção. Aquele não era um lugar apropriado para habitação, principalmente por causa da fraca infraestrutura: sem canalização de esgoto ou de água potável. As famílias e, em especial, as crianças viviam expostas a doenças em consequência das inundações frequentes. $O$ rio Tietê enchia e transbordava para as margens todos os anos, e então a favela ficava inundada. Era prefeito, na ocasião, Adhemar de Barros, e depois foi Prestes Maia" (Meihy \& Levine, 1994, p. 115).
} 
favelados do terreno situado entre as ruas Abílio Soares e Manoel da Nóbrega. O relatório informa que foram retirados desta área 186 barracos com 204 famílias. [Das quais uma parcela] foi encaminhada para a favela do Canindé (Meyer, 1991, p. 60).

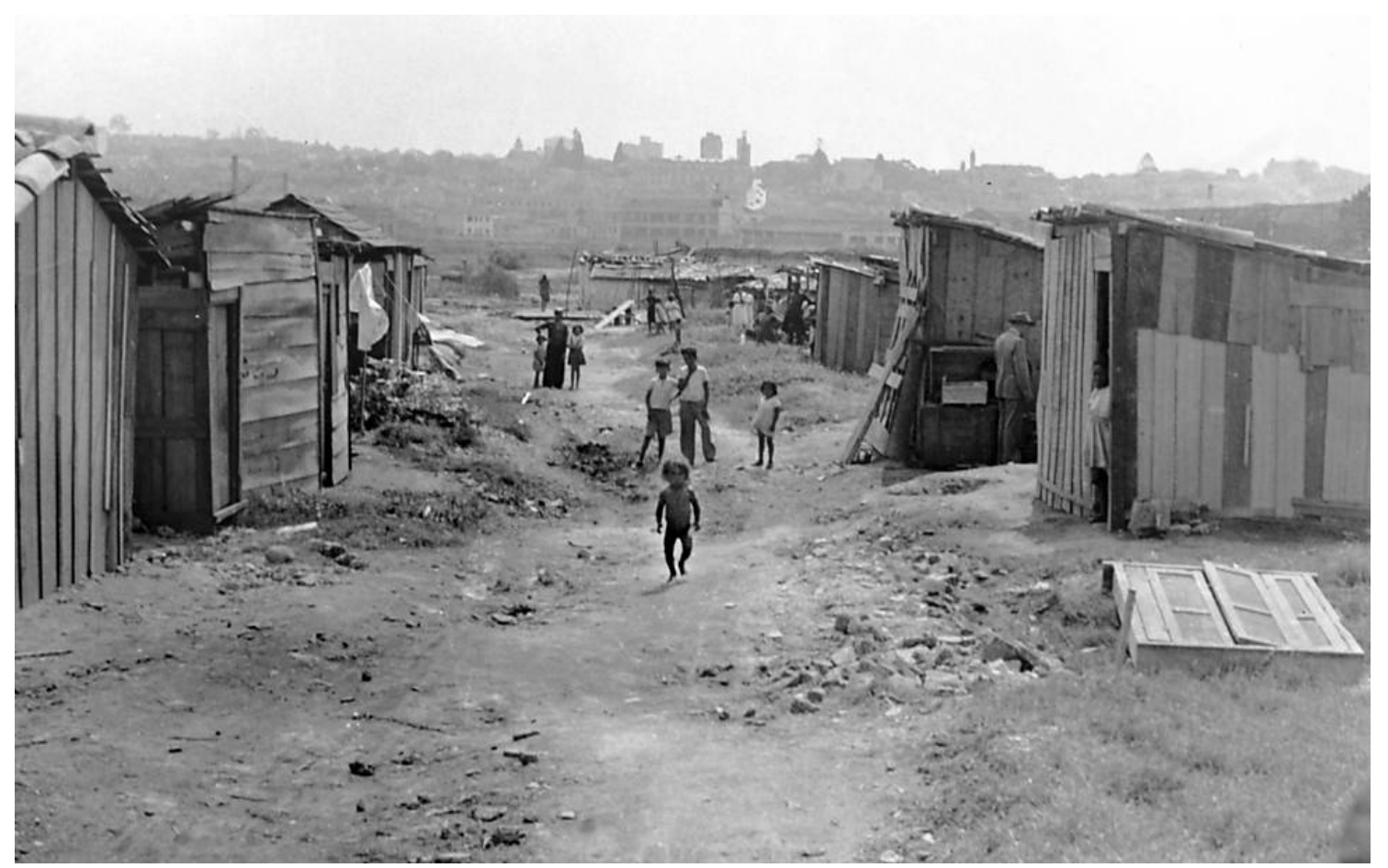

Figura 2:

Favela na Região do Ibirapuera, expropriada para construção do parque. São Paulo, 1950. Acervo Sebastião Assis Pereira.

Quando a escritora mudou-se para a tão sonhada casa de alvenaria, em meados dos anos 1960, a favela do Canindé já havia sido extinta para dar lugar à Marginal Tietê, cuja construção começou nos anos 50 e terminou nos anos 70. A favela do Canindé, tanto para o poder público que gerenciava as modificações na estrutura urbana quanto para seus moradores, era um espaço de transitoriedade. Segundo os depoimentos que Meihy colheu para o livro Cinderela Negra (Meihy \& Levine, 1994):

É fundamental que se diga que, na percepção de todos os depoentes, a favela era um estágio que logo seria superado. A noção de transitoriedade é uma constante, registrada com ênfase nas diversas entrevistas. Os narradores demonstram que a vida favelada correspondia a uma fase de adaptação entre o passado de migrantes e imigrantes e o futuro como trabalhadores adaptados ao progresso (Meihy \& Levine, 1994, p. 124).

De um lado, a favela representava para Carolina Maria de Jesus uma negação à sua condição de sujeito:

As oito e meia da noite eu já estava na favela respirando o odor dos excrementos que mescla com o barro podre. Quando estou na cidade tenho a impressão que estou na sala de visita com seus lustres de cristais, seus tapetes de viludos, 
almofadas de sitim. E quando estou na favela tenho a impressão que sou um objeto fora de uso, digno de estar num quarto de despejo (Jesus, 1960, p. 35).

Por outro lado, a escritora problematiza em sua narrativa a visão social comum que reinava entre os habitantes da "cidade do progresso" acerca da vida na favela, onde habitavam pessoas que a sociedade paulista considerava marginais: "nós somos pobres, viemos para as margens do rio. As margens do rio são os lugares do lixo e dos marginais. Gente da favela é considerado marginais. Não mais se vê os côrvos voando as margens dos rios, perto dos lixos. Os homens desempregados substituíram os côrvos" (Jesus, 1960, p. 55).

A saída que Carolina Maria de Jesus encontra é mudar-se com os filhos da favela saída individual - que já fora utilizada quando a autora parte do interior de Minas Gerais para a cidade de São Paulo: "Eu dava os parabéns a mim mesma, analisando a minha ascensão. Compreendi que dependia de mim mesma lutar para vencer" (Jesus, 1986, p. 197).

Considerando que a favela não constituía uma comunidade de pertença para a autora à altura que compôs Quarto de Despejo; que através da escrita ela conquistara as condições materiais necessárias para sair de lá; e que pela própria escrita ela ultrapassara lugares de subalternidade ao constituir na linguagem sua subjetividade, o epíteto de "escritora favelada" não condiz com a construção literária de Carolina Maria de Jesus, pois restringe seu campo discursivo ao universo do qual ela própria buscou afastar-se.

De fato, Carolina Maria de Jesus é precursora da Literatura Periférica no sentido de que ela é a primeira autora brasileira de fôlego a constituir a tessitura de sua palavra a partir das experiências no espaço da favela. Isto é, sua narrativa traz o cotidiano periférico não somente como tema, mas como maneira de olhar a si e a cidade. Por isso, seu olhar torna-se cada vez mais crítico diante do cenário de ilusões que São Paulo projetava com sua falsa imagem de lugar com oportunidades para todos - crença que a fez migrar de sua cidade natal na juventude.

Dentro do fazer literário, o periférico constitui um conceito diretamente relacionado a um modelo de representação que coloca em cena modos de significar o mundo e de produzir identidades. A literatura periférica, a partir do modo como esta se inscreve no contexto sociocultural e político em que se situa, das experiências por ela traduzidas e das identidades que engendra constitui um ethos novo diante da produção literária hegemônica, configurando outra via frente aos discursos dos que falam em nome dos marginalizados. 
A prática literária é articulada à própria experiência do espaço periférico, o que torna esta produção, antes de repertório de técnicas literárias, ferramenta para o entendimento e a organização social: uma estratégia de ação que rompe a compreensão da literatura apenas como bem espiritual, fonte de ilustração e prazer desinteressado. Nesse sentido, as reverberações ultrapassam o campo do estético, visto que a literatura é significada também como uma forma de articular a experiência de morar na periferia.

As décadas de história que separam a narrativa de Carolina Maria de Jesus da literatura periférica contemporânea - cujo Manifesto diz: "A periferia nos une pelo amor, pela dor e pela cor" ${ }^{2}$-é muito significativa para não ser considerada. A periferia hoje constitui seu próprio público leitor, pessoas que compartilham os mesmos códigos e que não buscam, $a$ priori, o aval da academia ou das grandes editoras. Saraus literários e selos alternativos possibilitam a circulação bem-sucedida dos textos, sem a necessidade primária de legitimação pelas vias "oficiais" do circuito literário. Este dado altera radicalmente o cenário, pois tal realidade não existia quando Quarto de despejo foi lançado.

\footnotetext{
9 de dezembro de 1962. Hoje eu estou triste. Não tenho dinheiro para comprar pão para os filhos. Fui pedir 100 a Elizabeth. O seu espôso disse-me que a Elizabeth, viajou para Santos. Tem pessôas que critica as viagens da Elizabeth. Mas eu não. A Elizabeth, e preta. Mas é feliz porque tem iluzão gosta de passear. Os pobres tem a iluzão que os ricos são felizes porque podem passear. E quando o pobre passêia pensa que é importante.

- Eu tambem já fui assim.

Quando estava na favela e vivia de esmola

Depois que deixei a favela que vida desgraçada! Todos dizem que fiquei rica. porque o livro foi editado em 21 pais - Até na Russia

E o pior é que passo mais fome do que na favela.

$\mathrm{Na}$ favela eu era mendiga. pedia e ganhava. Mas, agora se vou pedir esmola: ouço

- Você é rica!

Se vou procurar trabalho Ouço: você é rica!

Ha os que me invejam. O que eu sei é que eu tenho inveja dos favelados. Que podem procurar o que comêr no lixo.

- E eu?

- Que pavôr me inspira a palavra - Escritora (Jesus, 1996a, p. 256-257).
}

Com efeito, algum cuidado se faz necessário quando se considera, hoje em dia, Carolina Maria de Jesus, a "escritora favelada", como representante da literatura de periferia. É preciso atentar para as diferenças simbólicas entre a favela de agora e a dos anos 1950. E

\footnotetext{
2 "Manifesto da antropofagia periférica", por Sérgio Vaz. Disponível em: <http://www.polifoniaperiferica.com.br/2011/12/manifesto-da-antropofagia-periferica-por-sergio-vaz/>.
} 
ainda mais cuidado para escapar ao anacronismo e não assumir o mesmo discurso preconceituoso que emparedou a escritora em um lugar de subalternidade.

Talvez fosse mais difícil para Carolina Maria de Jesus tornar-se escritora se não tivesse migrado do interior rural, pois foi no chão da metrópole que ela encontrou as possibilidades necessárias para tal. Porém, tornar-se escritora de sucesso na metrópole do progresso teve um preço.

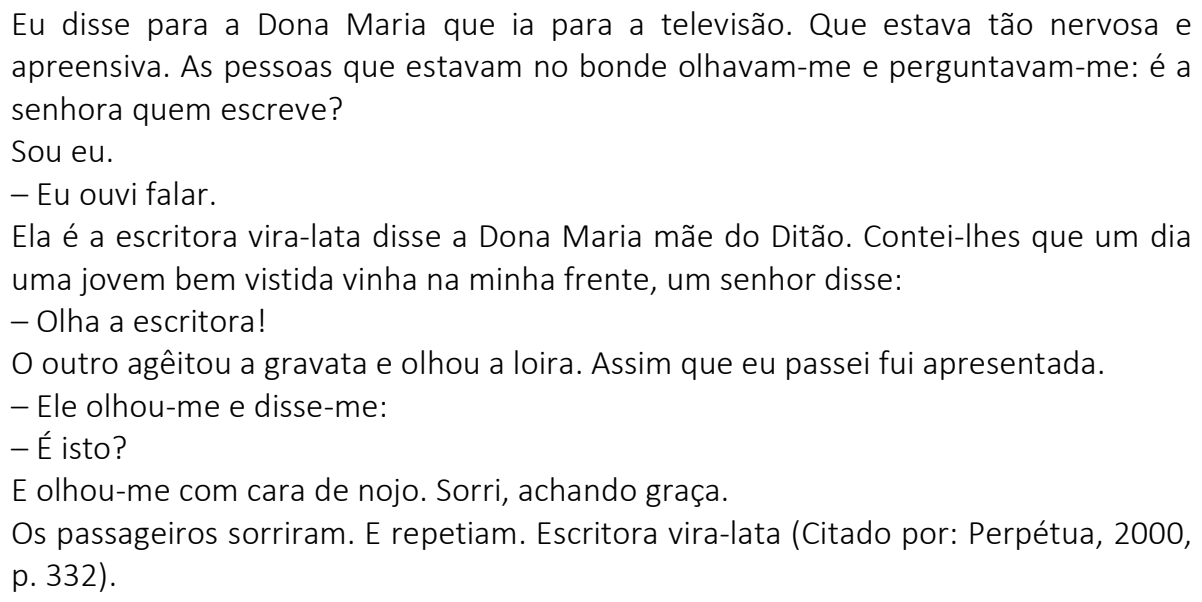

$\mathrm{Na}$ obra caroliniana normalmente mesclam-se as instâncias textuais autora/narradora/personagem, tornando problemática a delimitação rígida entre os campos do real e da ficção em sua obra. Isto é, embora a autora tangencie na linguagem a sua experiência concreta, esta experiência toma corpo na palavra, e o sujeito que é narrado torna-se signo, um ser de linguagem, e, portanto, dividido, disperso e disseminado na elaboração escrita. Nesse sentido, parece-nos que a consideração da obra caroliniana como documento - interpretação que segue o ponto de vista impresso pelo jornalista Audálio Dantas aos diários Quarto de Despejo e Casa de Alvenaria, editados por ele - é falha ao deixar escapar a sutileza de uma escritora que aliou a matéria histórica de sua experiência social à criação narrativa.

Isto posto, olhar a obra de Carolina Maria de Jesus apenas como documento de uma época implica ainda num ponto deveras importante: retirar, de sua escrita, a dimensão estética e privá-la de sua pertença ao campo do literário:

Eu disse: o meu sonho é escrever! Responde o branco: ela é louca.

O que as negras devem fazer...

É ir pro tanque lavar roupa

(Jesus, 1996b, p. 43). 
A construção do valor estético das obras literárias - ou da própria concepção do que venha a ser a literatura - abrange processos históricos tangentes às esferas que validam o texto como literário. Em sua Teoria da Literatura: uma introdução (1994), o crítico Terry Eagleton aborda o conceito de literatura como algo "funcional", posto que não se refira a uma essência comum encontrada em todos os textos considerados literários. Nesse sentido, o que define o caráter literário ou não literário de um texto é a forma como a sociedade onde ele é produzido ou lido entende por literário. Para Eagleton, a literatura é um tipo de escrita altamente valorizada, já que sua definição parte de um conjunto de valores vigentes que podem se modificar ao longo da história:

\begin{abstract}
Alguns textos nascem literários, outros atingem a condição de literários, e a outros tal condição é imposta. Sob esse aspecto, produção do texto é muito mais importante do que o seu nascimento. O que importa pode não ser a origem do texto, mas o modo pelo qual as pessoas o consideram. Se elas decidirem que se trata de literatura, então, ao que parece, o texto será literatura, a despeito do que o autor o tenha pensado. Nesse sentido, podemos pensar a literatura menos como uma qualidade inerente, ou como um conjunto de qualidades evidenciadas por certos tipos de escritos que vão desde Beowulf até Virginia Woolf, do que como as várias maneiras pelas quais as pessoas se relacionam com a escrita. Não seria fácil isolar, entre tudo o que se chamou de "literatura", um conjunto constante de características inerentes. Na verdade, seria tão impossível quanto tentar isolar uma única característica comum que identificasse todos os tipos de jogos. Não existe uma "essência" da literatura (Eagleton, 1994, p.13).
\end{abstract}

Entendemos que a crítica não está desvinculada dos processos históricos, posto que a análise literária é tão inscrita na história quanto a própria obra. Desse modo, a leitura feita do texto de Carolina nas décadas de 1960 e 1970 - como texto coletivo cujo valor era apenas o de encenar a palavra-denúncia das minorias - era própria de uma conjuntura histórica específica que pode vê-la somente enquanto narradora "orgânica" das contradições sociais advindas do processo de industrialização, urbanização e desenvolvimento capitalista ao qual passava a cidade de São Paulo.

A uma mulher negra, pobre e semialfabetizada não fora dado o direito ao discurso literário, mas tão somente o da legitimidade da voz para denunciar um estado de coisas que, de resto, incomodava a muitos na época dos "anos dourados": a proliferação das favelas na cidade onde o capitalismo apresentava maior grau de desenvolvimento do país.

Passados mais de cinquenta anos desde a publicação de seu primeiro livro (Quarto de despejo, 1960), defendemos nesta dissertação a produção textual de Carolina Maria de Jesus como obra literária, no sentido amplo do termo: de um pensamento elaborado com contornos estéticos, em que forma e conteúdo, texto e contexto, constituem uma dicção 
narrativa própria. Cremos que a construção desse pensamento se deu no percurso narrativo da autora e é repleto de choques, mudanças bruscas, contradições e incoerências, sendo, portanto, a análise isolada dos livros insuficiente para compreendê-lo plenamente. Não obstante, a abordagem da produção da autora a partir do estudo de seus textos em comparação, antes de revelar um sujeito uno e centrado em busca da voz própria por trás da escrita, deflagra o percurso de construção de uma identidade autoral própria.

Embora não seja considerada parte do cânone literário brasileiro, Carolina Maria de Jesus foi uma escritora de grande sucesso de público e há uma produção crítica considerável acerca de sua obra. Com um curioso intervalo de três décadas de silêncio após a publicação de Quarto de despejo nos anos 1960, a partir da década de 1990 importantes estudos foram lançados nos Estados Unidos e no Brasil. A primeira pesquisa brasileira substancial deve-se ao projeto integrado por José Carlos Sebe Bom Meihy e Robert M. Levine, junto às suas respectivas equipes, cuja colaboração possibilitou a divulgação de diversos textos inéditos da autora, resultando ainda na publicação, em 1994, do precioso trabalho Cinderela negra: a saga de Carolina Maria de Jesus, traduzido para o inglês por Levine com o título The life and death of Carolina Maria de Jesus ${ }^{3}$.

Concomitante ao estudo de Meihy e Levine, no início da década de 1990 a pesquisadora Elzira Divina Perpétua dedicou sua dissertação de mestrado: Solos e litorais da escrita: uma leitura de memórias marginais ao estudo comparativo de três narrativas: Quarto de despejo; Ai de vós! Diário de uma doméstica, de Francisca Souza da Silva e Cícera, um destino de mulher: autobiografia duma imigrante nordestina, de Cícera Fernandes de Oliveira e Danda Prado. Neste trabalho, defendido na PUC-MG em 1993, Perpétua discute o valor literário de tais obras, vistas quase que exclusivamente como contribuição sociológica. À luz da teoria da literatura, com os subsídios da semiótica, da psicanálise e da sociologia, o estudo é centrado no sujeito da narrativa em detrimento da valorização das autoras enquanto representantes de uma classe social e analisa-se de que forma essas três obras subvertem as noções instituídas do gênero memorialístico.

\footnotetext{
${ }^{3}$ Levine traduziu para o inglês o livro Casa de Alvenaria, junto com Melvin S. Arrigton Jr., com o título I'm going to have a litte house: the second diary of Carolina Maria de Jesus (1997). Arrigton é responsável por dois estudos dedicados à autora nos Estados Unidos: From the garbage dump to the brick house: the diaries of Carolina Maria de Jesus e Gnomic literature from the favela: the Provérbios of Carolina Maria de Jesus, ambos de 1993. Também nos Estados Unidos, Kamala Platt publicou em 1992 o texto Race and gender representations in Clarice Lispector's 'A menor mulher do mundo' and Carolina Maria de Jesus's 'Quarto de despejo'.
} 
Em 1995 Marisa Lajolo publica o artigo "A leitora no quarto dos fundos" (Lajolo, 1995), elabora o prefácio para Antologia Pessoal e inclui Carolina na antologia Nós e os outros: história de diferentes culturas (Lajolo, 2003). Lajolo é também responsável pela apresentação de Carolina na coleção Literatura e Afrodescendência no Brasil (Duarte \& Fonseca, 2011), a primeira antologia brasileira dedicada a escritores negros a incluir o nome da autora.

Em meados dos anos 2000 surgem três teses de doutorado dedicadas à autora. Elzira Divina Perpétua, na pós-graduação da UFMG, estudou a gênese, tradução e recepção do Quarto de despejo (Perpétua, 2000). A pesquisadora transcreveu em sua tese partes dos nove cadernos com manuscritos inéditos de Carolina que teve acesso e os cotejou com a edição feita por Audálio Dantas. As traduções de Quarto de despejo pelo mundo são analisadas cuidadosamente, bem como a recepção nacional de Carolina no contexto de estreia. O trabalho de Perpétua foi de fundamental importância para a escrita desta dissertação, textos longos de Carolina Maria de Jesus que estão em posse do editor - inéditos até virem a lume na tese - nos ajudaram a compreender a faceta escondida da autora na edição de Quarto de despejo preparada por Audálio Dantas.

Maria Madalena Magnabosco, também na UFMG, debruçou-se sobre o imaginário feminino nos testemunhos de Carolina, tangenciando a literatura à psicologia (Magnabosco, 2002). A pesquisadora intenta no trabalho "desconstruir os imaginários femininos formulados no processo de modernização brasileira entre as décadas de 50 e 70", através da análise dos "diários-testemunhos" de Carolina Maria de Jesus. A tarefa, de acordo com Magnabosco, é desmascarar "as duas representações comumente ligadas ao feminino pelo discurso hegemônico branco e masculino: a imagem da histérica e a imagem do subalterno". Teorias críticas feministas servem de suporte teórico à tese.

Em 2004, na UNB, Germana Henriques Pereira de Souza defendeu tese sobre o valor estético de duas obras da autora (Souza, 2004). A tese foi recentemente publicada em livro (Souza, 2012) sob o título Carolina Maria de Jesus: o estranho diário da escritora vira-lata.

Na Universidade de São Paulo há duas dissertações de mestrado sobre a autora, sendo esta a terceira. A primeira de 2008, defendida no Programa de Pós-graduação em Literatura Brasileira por Bianca Ribeiro Manfrini, sob orientação do Profo Dr. Marcos Antonio de Moraes, traz sob o título A mulher e a cidade: imagem da modernidade brasileira em quatro escritoras paulistas, uma análise comparativa entre Patrícia Galvão, Maria José Dupré, Carolina Maria de Jesus e Zulmira Ribeiro Tavares. Procura-se mostrar como o conteúdo histórico da 
modernidade brasileira se articula na forma dos textos das escritoras, compondo um painel fragmentário da cidade e discutindo suas obras em relação à produção canônica de sua época.

A segunda, de 2012, defendida no Programa de Pós-Graduação em Estudos Linguísticos, Literários e Tradutológicos em Francês por Erica Cristina de Oliveira, sob orientação do Profo Dr. Mario Laranjeira, com o título De Quarto de Despejo a Le dépotoir, o processo de refração na reescrita do diário de Carolina Maria de Jesus. Nesta dissertação a pesquisadora se apoia em Andre Lefevere, que explica que a refração é a adaptação de uma obra literária para um público diferente, com a intenção de influenciar a forma como este lerá a obra. A tradução é entendida como um tipo de refração. Partindo do pressuposto de que o livro publicado no Brasil constitui uma refração do verdadeiro texto de Carolina, as publicações do diário mundo afora difundiram pelo mundo uma imagem ainda mais refratada da autora e seus escritos. A pesquisa está centrada na tradução de Quarto de despejo para o francês, observando como a autora e seus escritos foram retratados no diário traduzido.

O Grupo de Trabalho A mulher na literatura, da Associação Nacional de Pós-graduação de Pesquisa em Letras e Linguística - ANPOLL, abriga em seu sítio na internet um verbete sobre Carolina, redigido por Maria Madalena Magnabosco e Graciela Ravetti ${ }^{4}$. Algumas pesquisadoras associadas ao GT desenvolveram trabalhos sobre Carolina Maria de Jesus, dentre as quais: Elódia Xavier, Maria Lúcia de Barros Mott e Maria Consuelo Cunha Campos.

Trabalhos cujas leituras enfatizam a intersecção gênero, raça e classe somam uma multiplicidade de artigos acadêmicos publicados em livros e em periódicos eletrônicos diversos ${ }^{5}$. O nome de Carolina Maria de Jesus está presente em algumas obras de referência da literatura nacional, por exemplo, o Dicionário literário brasileiro, de Raimundo de Menezes, a Enciclopédia de literatura brasileira do MEC/FAE e o Dicionário mundial de mulheres notáveis, de Américo Lopes de Oliveira e Mário Gonçalves Viana.

Neste trabalho, organizamos a análise em três capítulos. O capítulo um: A gênese de Carolina Maria de Jesus se divide em dois subtópicos, no primeiro: "A escritora", apresentamos a autora, traçando um panorama geral de sua trajetória, enfatizando dois pontos centrais: o processo de aquisição da leitura na infância e a sua chegada em São Paulo.

\footnotetext{
${ }^{4}$ Disponível em: < http://www.amulhernaliteratura.ufsc.br/catalogo/carolina vida.html>.

${ }^{5}$ Apresentamos um apanhado de alguns desses trabalhos na bibliografia consultada sobre Carolina Maria de Jesus.
} 
Articulamos a publicação do diário Quarto de despejo à surpresa geral e desentendimento da critica quanto à nova escritora, alcançando os primeiros resultados da recepção à obra. No segundo subtópico: "Margens do texto: Quarto de despejo e a representação coletiva", a discussão é voltada para os procedimentos de editoração do livro publicado, direcionando a reflexão para as estratégias empreendidas pelo editor a fim de construir uma persona para Carolina Maria de Jesus, capaz de legitimá-la como representante da coletividade favelada e porta-voz das minorias. Analisa-se o prefácio do diário, preparado por Audálio Dantas, e alguns excertos de manuscritos de Carolina Maria de Jesus comparando-os com o texto publicado, observando as modificações empreendidas na escrita da autora.

O segundo capítulo, A experiência da escrita e a escrita da experiência, está estruturado em três subtópicos. No primeiro: “Uma mulher negra (e pobre) levanta a opinião pública" adentramos o cenário histórico e político da época de lançamento do Quarto de despejo, buscando compreender as movimentações sociais que receberam Carolina Maria de Jesus, protagonista do maior sucesso editorial de um escritor negro no século XX, e o lugar polêmico, do ponto de vista da crítica, que ela ocupou - e ocupa - na discursividade afrobrasileira. No segundo subtópico: "Construção estética da experiência: o "ideal de poeta" de Carolina Maria de Jesus" iniciamos a leitura voltada para a escrita de Carolina Maria de Jesus propriamente, adentrando seu universo narrativo. O "ideal de poeta" da autora é a trilha para compreendermos seu percurso literário e as suas concepções e entendimentos acerca da literatura, que para ela não estava separada da própria vida, ao contrário, Ihe constituía. No terceiro e último subtópico do capítulo: "A escrita ficcional: a experiência, a cidade e a escassez" atentamos para a realização literária de Carolina Maria de Jesus, considerando que sua obra, em conjunto, constitui uma morfologia da experiência marginal na modernidade, cujos eixos se concentram em duas estruturas problemáticas: a cidade e a escassez. Voltamonos para a leitura de Pedaços da Fome, único romance publicado da autora, analisando as marcas de convergência com o ponto de vista da narradora da escrita diarística.

O capítulo três, A "Escrita de Si", dividi-se em dois subtópicos. No primeiro, "Casa de alvenaria - diário de uma ex-favelada", procuramos analisar o segundo livro publicado considerando as definições propostas por Philippe Lejeune para o gênero diário, assentadas na marcação do tempo; na destinação; na forma e no conteúdo. Neste capítulo também chegamos ao momento de desilusão da escritora para com o universo da literatura, devido às dificuldades que o sucesso do livro anterior ocasionara, posto que a mudança da favela e do 
conteúdo narrativo do diário dissipara o interesse do público pela autora. No segundo, "Um Brasil para os brasileiros e a vida de Bitita" centramo-nos na leitura de Diário de Bitita, livro publicado postumamente em que Carolina Maria de Jesus constrói as memórias de sua infância e juventude, antes de chegar à cidade de São Paulo. Este livro, embora traga o gênero diário no título, é uma mescla de autobiografia com ficção de si, em que a autora constrói a sua condição de poetisa como algo presente desde a primeira infância. Observamos a construção do foco narrativo formulado desde a perspectiva do não-lugar dos negros no quadro social da cidade e, junto a isso, a elaboração de uma ficção de si pelas memórias da menina Carolina Maria de Jesus.

Nesta dissertação, intentamos trazer para o centro da crítica o texto de Carolina Maria de Jesus. Por isso as longas citações da autora, fruto da opção por não editar os excertos escolhidos, a fim de dar ao leitor a chance de deleitar-se com as palavras da escritora. 
Eu não queria que o leitor tivesse tempo para pensar: "O que é que eu tenho que fazer, do que tenho que abrir mão para ler isto? De que defesa preciso, que distancia manter?"

- Toni Morrison 


\section{A GÊNESE DE CAROLINA MARIA DE JESUS}

\section{1 - A escritora}

As minhas palavras ferem mais do que espada.

E as feridas são incicatrisaveis.

- Carolina Maria de Jesus

A certa altura, em A hora da estrela, o narrador (se) confessa:

Escrevo por não ter nada a fazer no mundo: sobrei e não há lugar para mim na terra dos homens. Escrevo porque sou um desesperado e estou cansado, não suporto mais a rotina de me ser e se não fosse a sempre novidade que é escrever, eu me morreria simbolicamente todos os dias (Lispector, 1999, p. 21).

Por não ter mais nada a fazer no mundo o narrador desenha as linhas e traçados da inesquecível jovem - nordestina, feia, parda e inapta - Macabéa.

O que escrevo é mais do que invenção, é minha obrigação contar sobre essa moça entre milhares delas. E dever meu, nem que seja de pouca arte, o de revelar-lhe a vida. Porque há o direito ao grito. Então eu grito (Lispector, 1999, p. 13).

Dispõe-se a gritar, então, o narrador, para que a história da subterrânea Macabéa ecoe e ela possa existir através dele. O escritor, de acordo com Barthes, é o que fala no lugar de outro (Barthes, 1999, p. 33). Se considerarmos a literatura como uma forma de representação, o questionamento acerca deste "outro" se faz necessário, pois evoca a problemática em torno do lugar de fala: quem fala e em nome de quem.

A novela de Clarice Lispector foi publicada em outubro de 1977, dois meses antes da morte da própria escritora, aos 57 anos. Neste mesmo fatídico 1977, o Brasil também perdera a escritora Carolina Maria de Jesus, aos 62 anos. O grito, sendo uma capacidade comum, fora trabalhado por ambas em suas obras, e, aqui, possivelmente, terminam as semelhanças. 0 narrador Rodrigo S.M., intelectual que se dispõe a contar a história da jovem Macabéa, diz entre parênteses:

(Se o leitor possui alguma riqueza e vida bem acomodada, sairá de si para ver como é às vezes o outro. Se é pobre, não estará me lendo porque ler é supérfluo para quem tem uma leve fome permanente. Faço aqui o papel de vossa válvula de escape e da vida massacrante da média burguesia. Bem sei que é assustador sair de si mesmo, mas tudo o que é novo assusta. Embora a moça anônima da história seja 
tão antiga que podia ser uma figura bíblica. Ela era subterrânea e nunca tinha tido floração. Minto: ela era capim) (Lispector, 1999, p. 30-31).

Diferente do subterrâneo sem floração de que se fazia a personagem Macabéa, uma superfície completamente nova passara a existir com as palavras da autora Carolina Maria de Jesus. Ler, para Carolina, e escrever, principalmente, eram ações exatamente contrárias ao que emana do campo semântico do supérfluo, como Rodrigo S.M. entende ser comum quanto ao ato de ler para "quem tem uma leve fome permanente". A relação de Carolina Maria de Jesus com a escrita é similar ao expresso pelo narrador clariciano: "se não fosse a sempre novidade que é escrever, eu me morreria simbolicamente todos os dias", pois Carolina escrevia justamente para estar no mundo, para saber-se parte dele, para sobreviver: "Hoje estou com frio. Frio interno e externo. Eu estava sentada ao sol escrevendo e supliquei, oh meu Deus! Preciso de voz" (Jesus, 1996a, p. 152).

Em vida, desafiou todos os lugares comuns em que tentaram encaixá-la: "não me adapto a ser teléguiada" (Jesus, 1996a, p. 136), dizia. O conjunto de sua escrita, de teor largamente autorreferencial - em que a vida e a obra não são instâncias separadas - traz uma voz autoral que problematiza tanto a noção em torno de "quem fala" quanto os pressupostos em torno de "quem ouve".

A obra caroliniana publicada é composta de três diários: Quarto de Despejo: diário de uma favelada (1960); Casa de Alvenaria: diário de uma ex-favelada (1961) e Diário de Bitita (1986); um romance: Pedaços da Fome (1963); uma coletânea de poemas: Antologia Pessoal (1996) e uma compilação de pensamentos intitulada Provérbios (1963).

Quando estreou, nos anos 1960, sua obra rapidamente destacou-se do parâmetro comum de vendas de livros no país. Lançado em agosto, Quarto de despejo - diário de uma favelada foi imensamente celebrado no Brasil e em muitos lugares do mundo. O público foi gigantesco, tornou o diário best-seller. Carolina Maria de Jesus foi, àquela altura, uma das autoras mais célebres de nossas letras. Tão célebre que seu diário foi publicado em mais de quarenta países e traduzido para treze línguas.

O livro significa um marco no mercado editorial nacional: somente nos três primeiros dias após o lançamento foram vendidos dez mil exemplares. Na tarde de autógrafos 600 
exemplares $^{6}$. A primeira tiragem, que inicialmente seria de 3.000 livros, passou a 30.000,

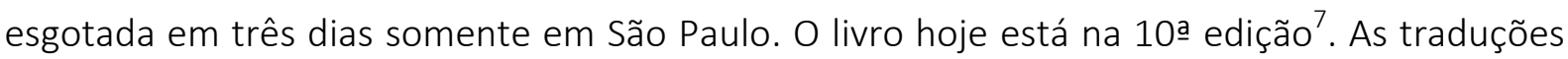
do Quarto de despejo começaram a circular menos de um ano depois de seu lançamento no Brasil, em edições produzidas na Dinamarca, Holanda e Argentina (1961); França, Alemanha (Ocidental e Oriental), Suécia, Itália, Checoslováquia, Romênia, Inglaterra, Estados Unidos e Japão (1962); Polônia (1963); Hungria (1964); Cuba (1965) e entre 1962 e 1963 na União Soviética. Para a época, um feito ${ }^{8}$. Um grande feito, a propósito, considerando tratar-se de uma autora anônima e estreante, que foi lida por "capitalistas" e "socialistas", "ocidentais" e "orientais", "desenvolvidos" e "subdesenvolvidos", numa época em que o mundo se dividia em tantos blocos antagônicos.

Além do fenômeno editorial, Carolina Maria de Jesus tornou-se tema de manchetes na imprensa escrita, falada e televisionada em diversos países do mundo. Foi destaque, por exemplo, no New York Times, que considerou seu livro "penetrante ensaio sobre o significado da fome, degradação, e perseverança" (Meihy, 1994, p. 18) e comparou o sucesso comercial de Carolina àquele alcançado por Lolita, de Nabokov, publicado no ano de 1955. Foi assunto de uma página inteira da revista Life e sua história foi contada em pormenores na Paris Match.

O livro inspirou ainda diálogos com outras linguagens, como o teatro, o cinema, a televisão e a música, demonstrando seu impacto na esfera cultural: em 1961, Edi Lima fez uma adaptação para o teatro - a peça foi encenada no Teatro Bela Vista, na cidade de São Paulo, dirigida por Amir Haddad e contando com Ruth de Souza no elenco; Quarto de despejo virou roteiro de um filme chamado "Despertar de um sonho", feito pela televisão alemã nos

\footnotetext{
${ }^{6}$ Na reportagem de 20 de agosto de 1960 da Folha da Manhã, afirma-se: "foram batidos todos os recordes de venda de livros em tardes de autógrafos na festa do lançamento da obra de Maria Carolina de Jesus (sic) [...] pela primeira vez uma livraria foi invadida pelo povo que se exprimia em todo recinto. [...] Carolina autografou mais livros que os três recordistas anteriores: bateu sucessivamente Alzira Vargas, Carlos Lacerda e Jorge Amado: seiscentos livros".

${ }^{7}$ A 1 ạ edição de Quarto de despejo foi reimpressa sete vezes em 1960 e uma vez em 1963, pela Livraria Francisco Alves Editora. A Ediouro imprimiu duas edições de bolso em 1976 e em 1983 a Francisco Alves fez uma 10ạ edição do livro. Em 1990 o Circulo do Livro lançou outra edição e em 1993 a Editora Ática publicou uma edição de bolso, com novos suportes editoriais e ilustrações.

${ }^{8}$ Segundo Meihy \& Levine, "no espaço de um ano ela havia se equiparado, em vendagem, a Jorge Amado, e com ele se transformado no mais traduzido dos autores brasileiros de todos os tempos" (Meihy \& Levine, 1994, p. 25-26). Em termos estritamente mercadológicos, o sucesso editorial do livro e a quantidade de traduções mundo afora poderia ser comparado, em tempos atuais, apenas ao fenômeno editorial Paulo Coelho com "O Alquimista", de 1988.
} 
anos 70 e jamais exibido no Brasil; em 1983, a Rede Globo fez uma adaptação do diário para a série Caso Verdade; finalmente, B. Lobo compôs uma letra de samba chamada "Quarto de despejo", gravado por Ruth Amaral, em que se diz:

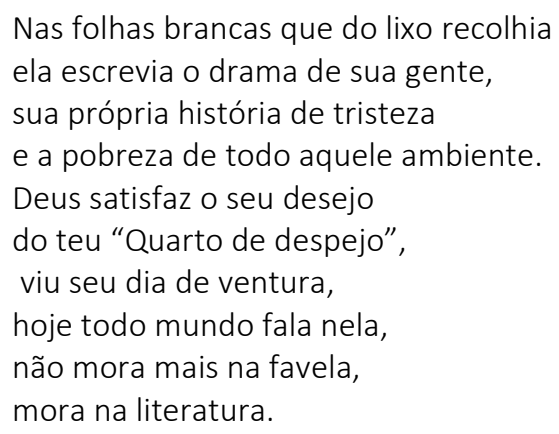

Passados mais de meio século da data de publicação, o diário continua instigando diálogos férteis com diversos segmentos da arte e da cultura, como por exemplo: o curtametragem "Carolina" (2003), do cineasta Jeferson De, que foi considerado "Melhor Curta" e ganhou o Prêmio da Crítica no Festival de Gramado, trazendo Zezé Motta no papel da escritora. Na esfera musical, o CD "Hoje eu tive um sonho... Carolina de Jesus", resultado do Projeto Dimensões de Gênero e Raça do Movimento Hip Hop, apoiado pela Fundação Cultural Palmares. A biblioteca "Carolina Maria de Jesus", do Museu Afro Brasil, homenageia a escritora; na Cidade Tiradentes, periferia da Zona Leste de São Paulo, também há uma biblioteca pública que recebe o seu nome. Carolina Maria de Jesus é nome de rua em São Paulo e também de escola pública estadual. No âmbito da organização política, há na baixada santista a "Associação de Mulheres Carolina Maria de Jesus", onde se reúnem mulheres negras moradoras da periferia da cidade de Guarujá que se autodenominam "Carolinas". A poetisa Maria Teresa, em seu livro "Negrices em flor", publicado pelas Edições Toró em 2007, chama Carolina em sua rima. No poema citado abaixo a poetisa negra paulistana da Zona Norte atualiza a experiência caroliniana na literatura ao lançar mão da recusa em ter que caber nos formatos e padrões que não condizem com seu próprio pisar:

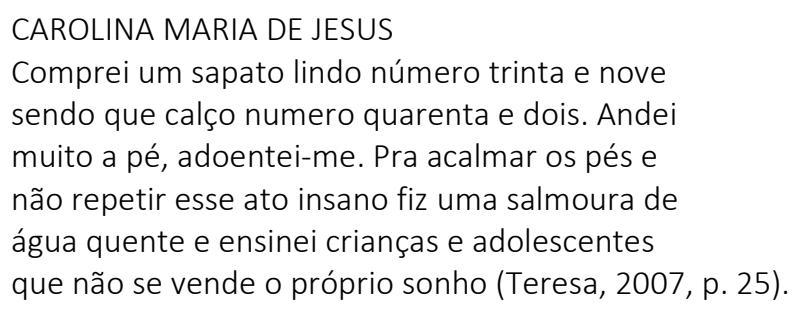

Com as palavras citadas abaixo se inicia Quarto de despejo: diário de uma favelada (1960) de Carolina Maria de Jesus: 
15 de Julho de 1955. Aniversário de minha filha Vera Eunice. Eu pretendia comprar um par de sapatos para ela. Mas o custo dos generos alimenticios nos impede a realização dos nossos desejos. Atualmente somos escravos do custo de vida. Eu achei um par de sapatos no lixo, lavei e remendei para ela calçar.

Eu não tinha um tostão para comprar pão. Então eu lavei 3 litros e troquei com o Arnaldo. Êle ficou com os litros e deu-me pão. Fui receber o dinheiro do papel. Recebi 65 cruzeiros. Comprei 20 de carne. 1 quilo de toucinho e 1 quilo de açucar e seis cruzeiros de queijo. E o dinheiro acabou-se.

Passei o dia indisposta. Percebi que estava resfriada. A noite o peito doia-me. Comecei tussir. Resolvi não sair a noite para catar papel. Procurei meu filho João José. Êle estava na rua Felisberto de Carvalho, perto do mercadinho. O ônibus atirou um garoto na calçada e a turba afluiu-se. Êle estava no nucleo. Dei-lhe uns tapas e em cinco minutos êle chegou em casa.

Ablui as crianças, aleitei-me e ablui-me e aleitei-me. Esperei até as 11 horas um certo alguem. Êle não veio. Tomei um melhoral e deitei-me novamente. Quando despertei o astro rei deslisava no espaço. A minha filha Vera Eunice dizia: - Vai buscar agua mamãe! (Jesus, 1960, p. 13).

Sobressaem no fragmento citado abaixo alguns dos temas mais recorrentes do livro publicado: a luta diária pela vida, circunscrita no "cerco da economia de sobrevivência que tranca sua vida ao dia-a-dia do dinheiro-coisa" (Vogt, 1983, p. 210); os pensamentos acerca da rotina da favela e da cidade; as demandas trazidas pelos filhos na dinâmica cotidiana; a construção discursiva detalhada em torno das situações vividas, estruturada sob o ponto de vista de quem narra, como é característico das obras confessionais - "aquela [s] em que o sujeito se expressa, isto é constrói o fio das impressões que constituem a trama da experiência" (Damião, 2006, p. 11).

Porém, antes de voltarmo-nos propriamente ao fio do diário, quem era Carolina Maria de Jesus?

Nascida no interior rural de Minas Gerais, filha de mãe solteira, ela própria mãe solteira de três filhos - cada qual de um pai diferente; chefe de família, migrante, negra retinta, de baixa escolaridade, catadora de papel e outras sucatas, cantora, compositora, escritora. Quando nasceu, em 1914, a cidade de Sacramento tinha apenas duas ruas grandes: a Rua do Comércio e a Avenida Municipal. O restante da cidade se espalhava em outras dezoito ruas, todas retas e largas (Castro \& Machado, 2007, p. 14). Nascida na segunda geração após o fim da escravidão, seu maior referencial familiar era o avô, conhecido como "Sócrates Africano".

A escravidão negra - base econômica, social e política do Brasil durante séculos havia sido abolida na letra da lei há exatos vinte e seis anos quando Carolina veio ao mundo. "Em Sacramento chamavam a casa de senzala, mas a escravidão acabara há tanto tempo que ninguém podia falar dela com autoridade" (Santos, 2009, p. 11). A cidade de Sacramento é 
parte da região do Triângulo Mineiro, lugar de terras férteis com abundância de metais e pedras preciosas. De acordo com pesquisas do professor e sociólogo Júlio César Pereira, parte da comunidade negra de Sacramento é proveniente do Quilombo do Ambrósio, da região de Araxá, dizimado a partir do ano de 1740 (Pereira, 2008). Na biografia de Carolina Maria de Jesus realizada por Eliana de Moura Castro e Marília Novais da Mata Machado afirma-se que a cidade foi fundada em 1820, como consequência do bandeirantismo paulista que se espalhava pelos interiores do Brasil alcançando o então chamado Sertão da Farinha Podre terras compreendidas entre o Rio Grande e o Paranaíba - em busca de riquezas. A base econômica da cidade se sustentava no plantio de café e Sacramento se desenvolveu como um lugar de características provincianas, donde as famílias de posse, apoiadas na política do coronelismo, comum no Brasil da primeira República, mandavam e desmandavam: "O coronel, chefe político local, era proprietário de grandes terras, frequentemente exportador. Seus agregados e dependentes formavam as milícias locais. As disputas se resolviam pelas armas. Funcionários da justiça, da polícia, coletores fiscais, professores, padres, médicos, advogados mantinham boas relações com os coronéis e executavam suas ordens e desejos" (Novais \& Machado, 2007, p. 15, 16).

Em Diário de Bitita (1986), seu livro póstumo centrado na narrativa da infância e juventude, Carolina Maria de Jesus dedica boa parte da composição de suas memórias a considerações sobre a vida social dos moradores da cidade, demonstrando o lugar de opressão ao qual estavam relegados negros e negras pobres:

As empregadas eram obrigadas a cozinhar, lavar e passar. [...] Deixavam o trabalho às onze da noite. Trabalhavam exclusivamente na cozinha. Era comum ouvir as pretas dizerem: - Meu Deus! Estou tão cansada!

Uma boa cozinheira ganhava trinta mil-réis por mês. Quando vencia o mês e a cozinheira recebia, ela tinha a impressão de ser uma heroína. Enaltecia a si mesma dizendo: - Eu sou forte! Não é qualquer uma que aguenta cozinhar para o doutor Souza. Que orgulho, que vaidade, ser a cozinheira do doutor José da Cunha ou do presidente Franklin Vieira e José Afonso. Era comum ouvir os ricos dizerem: - Sabe com quem você está falando? Eu sou o manda-chuva! E as pretas pernósticas às vezes diziam: - Sabem com quem cê tá falando? Eu sou a cozinheira do presidente. Quando as cozinheiras sentiam sono, iam lavar o rosto na água fria para despertá-lo. O único medo era o de salgar a comida e a patroa dar a conta. Eram muitas pessoas para trabalhar e pouquíssimos os locais para trabalhar. A patroa era tratada como se fosse uma santa no altar. Se as patroas estivessem nervosas, as empregadas deveriam dizer: - Sim senhora! Se estivessem amáveis tinham que dizer: - Sim senhora! O homem pobre deveria gerar, nascer, crescer e viver sempre com paciência para suportar as filáucias dos donos do mundo. Se o filho do patrão espancasse o filho da cozinheira, ela não podia reclamar para não perder o emprego. Mas se a cozinheira tinha filha, pobre negrinha! O filho da patroa a usaria para o seu noviciado sexual. Meninas que ainda estavam pensando nas bonecas, nas cirandas e cirandinhas eram brutalizadas pelos filhos do senhor Pereira, Moreira, 
Oliveira, e outros porqueiras que vieram do além-mar. No fim de nove meses a negrinha era mãe de um mulato, ou pardo. E o povo ficava atribuindo paternidade: - Deve ser filho de fulano! Deve ser filho de sicrano! Mas a mãe, negra, insciente e sem cultura, não podia revelar que seu filho era filho do doutor $X$, ou $Y$. Porque a mãe ia perder o emprego. Quantas mães solteiras se suicidavam, outras morriam tísicas de tanto chorar. O pai negro era afônico; se pretendia reclamar, o patrão impunha: - Cala a boca negro vadio! Vagabundo! E se o doutor Oliveira que estudou em Coimbra dissesse: - Negro ladrão... aquilo ia transferindo-se de boca em boca. E aquele negro, sem nunca ter roubado era um ladrão. E não se reabilitava jamais. Ficava por ali mesmo e se transformava em chacota da molecada. E o filho do senhor Oliveira, depois de farto da sedução de mocinhas pobres, decidia casar-se com a filha do senhor Moreira, ela era rica (Jesus, 1986, p. 33, 34, 35).

A menina Bitita - para os mais íntimos, aprendeu a ler em um colégio espírita chamado Instituto Allan Kardec, posteriormente fechado por influência da igreja e das famílias católicas locais. Lá, Carolina permaneceu por apenas dois anos, únicos em sua formação escolar formal - devido ao favor - nossa mediação quase universal ${ }^{9}$, de uma senhora muito rica, a Dona Maria Leite:

- Eu sou francesa. Não tenho culpa da odisséia de vocês; mas eu sou muito rica, auxilio vocês porque tenho dó. Vamos alfabetizá-los para ver o que é que vocês nos revelam: se vão ser tipos sociáveis e tendo conhecimento poderão desviar-se da deliqüência e acatar a retidão (Jesus, 1986, p. 123).

O favor da senhora rica fora tomado literalmente como ordem pela mãe de Carolina, que via pouco sentido em enviar a filha à escola. Porém, desagradar a senhora estava fora de questão: "Minha mãe era tímida. E dizia que os negros devem obedecer aos brancos, isto quando os brancos tem sabedoria. Por isso ela devia enviar-me à escola, para não desgostar a dona Maria Leite" (Jesus, 1986, p. 123).

Na escola, Carolina ouviu pela primeira vez seu nome próprio:

Eu gosto de ser obedecida. Está ouvindo-me, dona Carolina Maria de Jesus! Fiquei furiosa e respondi com insolência:

- O meu nome é Bitita.

- O teu nome é Carolina Maria de Jesus.

Era a primeira vez que eu ouvia pronunciar o meu nome.

- Eu não quero este nome, vou trocá-lo por outro.

A professora deu-me umas reguadas na perna, parei de chorar. (Jesus, 1986, p. 124, ênfase minha).

Na construção das memórias, como o exemplo acima já adianta, a escritora demarca a diferença entre dois tempos e duas instâncias de sujeito: Bitita - menina que afirma com conviç̧ão sua existência a partir da afirmação do seu nome; e Carolina Maria de Jesus - que

\footnotetext{
${ }^{9}$ A expressão é de Roberto Schwarz, para quem o favor materializava o acesso à vida social e a seus bens para a classe dos "homens livres", na verdade dependentes, na ordem colonial e depois. Ver o ensaio "As ideias fora de lugar" (Schwarz, 2000, p. 16).
} 
passa a existir no texto primeiramente através do ato de nomeação executado pela professora. Além da separação entre a esfera familiar e a escolar a partir do nome, na narrativa de memórias de si, a autora cria, no mesmo movimento, identidade e alteridade: Carolina se "outriza" e seu "outro" é ela mesma.

Para Philippe Lejeune, "é no nome próprio que pessoa e discurso se articulam" (Lejeune, 2008, p. 22). Na obra caroliniana o nome próprio, potencializado como nome de autor, engendra a constituição de sua subjetividade em relação direta com a escrita, como poderemos notar ao adentramos seu universo narrativo.

O repórter desembrulhou os livros e deu-me um. Fiquei alegre olhando o livro e disse: - O que eu sempre invejei nos livros foi o nome do autor. E li o meu nome na capa do livro. Carolina Maria de Jesus. Diário de uma favelada. QUARTO DE DESPEJO. Fiquei emocionada. O repórter sorria: - Tudo bem, não é, Carolina? - Oh! Sim. Tudo bem. É preciso gostar de livros para senti o que eu senti (Jesus, 1961, p. 33).

O nome próprio estampado na capa de um livro autobiográfico, de acordo com Lejeune, "resume toda a existência do que chamamos de autor" e sustenta o pacto autobiográfico entre o autor e o leitor. Não obstante, no caso de nossa escritora, a própria noção de autor é fruto de uma construção discursiva paulatina.

Após estes dois únicos anos de escolarização primária, obrigada a deixar o colégio quando sua família muda-se para outra localidade em busca de trabalho, nunca mais Carolina abandonou os livros e cadernos. A intermitente procura por ocupações que garantissem o sustento a levou junto com sua mãe a cidades de Minas Gerais, como Uberaba, e posteriormente do interior do Estado de São Paulo, como Ribeirão Preto, Jardinópolis, Sales de Oliveira, Orlândia, Franca. Em 31 de janeiro de 1937, aos trinta e três anos e sozinha, Carolina chega à cidade de São Paulo, destino privilegiado dos migrantes de todo o país ${ }^{10}$.

\footnotetext{
${ }^{10}$ Historicamente, São Paulo foi o destino de diversas correntes migratórias. Na segunda metade do século XX, a aceleração das atividades industriais atraiu a força de trabalho ociosa ou subocupada das áreas rurais ou semi rurais. A "locomotiva do Brasil" atraía migrantes de todos os locais do país, e a favela, um fenômeno recente por essa época, tornou-se pauta do debate político. A favela da Canindé, onde Carolina residiu, era povoada principalmente por migrantes que começaram a chegar à cidade da indústria e do trabalho. Na transição da década de 1940 para a de 1950 estima-se que 50 mil favelados viviam em sete locais da cidade. Nos anos 1950 a população brasileira rural era 64\% em oposição a 36\% urbana. Nos anos 1960 era 55\% para 45\%, na década de 1970 a população rural passou a ser $44 \%$ contra 56\% da urbana. Para estabelecer uma comparação, o Rio de Janeiro no mesmo período, bem menos industrializada que São Paulo, possuía 200 favelas habitadas por pelo menos 337 mil moradores (Meihy \& Levine, 1994, p. 49). Numa fase anterior, entre 1888 e 1928, ocorreu elevado fluxo de imigração europeia para o estado de São Paulo: "Nos quarenta anos que se seguiram à abolição, São Paulo recebeu mais de dois milhões de imigrantes europeus, dos quais quase metade tiveram suas passagens transatlânticas pagas pelo governo do Estado. Esses imigrantes foram levados para São Paulo para
} 
Quando Carolina Maria de Jesus chegou às terras paulistas, junto com os patrões que mais tarde abandonaria, "o dia estava despontando e estava chovendo. Fiquei atónita com a afluencia das pessoas na estação da Luz. (...) tinha a impressão de estar transferindo-me de um planêta para outro" (Meihy \& Levine, 1994, p. 185). A alusão da distância entre os lugares que vivera e a pauliceia com aquela de um planeta a outro é excelente para sinalizar o enorme descompasso que havia entre a metrópole em expansão e os interiores:

Nunca havia visto tantas pessoas reunidas. Pensei: "será que hoje é dia de festa?" Fiquei preocupada com o corre-corre dos paulistanos. Olhares anciosos inquietos a espera das conduções. Uns empurrando os outros e ninguém reclamava aquilo seria normal? [...] Nos dá a impressão, que o povo não tem educação. Quando um empurra, o outro não pede desculpas. È semelhante a uma colméia humana. Uns correm para cima outras correm para baixo. Em todas as direções que se olha, alguém está correndo (Meihy \& Levine, 1994, p. 185).

A experiência da multidão é o primeiro registro da chegada de Carolina Maria de Jesus na metrópole. Pareceu-lhe que o espetáculo de ver tantas pessoas reunidas correndo para todas as direções em que o olho alcançasse poderia tratar-se de evento isolado: aquele seria dia de festa? De fato, ainda era muito cedo para que a mineira recém-chegada do interior notasse que a multidão era fenômeno cotidiano na estação da Luz em meados do meio século XX paulistano.

Não senti a sensação almejada. Contemplava tudo com indiferença, sentia profundo pavêr da cidade industrial. Porqué? Não sei. Olhava aquele povo bem vestido. "Será que todos êles são ricos?" olhava os brancos, estavam bem vestidos. Olhava os prêtos, estavam bem vestidos. Os que falavam, tinham dentes na boca e sorriam. E se o povo esta sorrindo entao a cidade é boa. Aquela tristeza que senti foi desaparecendo aos poucos. Só no interior eu era tranquila; mas percebi que o meu pensamento ia modificando-se. Era uma transição que não era possível domina-la. Que desordem mental tremenda. Sentia ideias que eu desconhecia como se fosse alguém ditando algo na minha mente (Meihy \& Levine, 1994, p. 185).

Em São Paulo Carolina Maria de Jesus permaneceu o restante de sua vida, transitando entre espacialidades diferentes - e até opostas - da topografia urbana da Urbis moderna: da favela do Canindé - para a área nobre de Santana - para o sítio em Parelheiros, periferia extrema e isolada da cidade. Inicialmente trabalhando como empregada doméstica, a autora não conseguiu adaptar-se às regras do trabalho doméstico semicolonial - dormir no serviço, não ter permissão de sair à noite, aguentar desaforos dos patrões - e logo abriu mão desta ocupação. De acordo com suas próprias palavras, ela era muito independente para passar a vida limpando as bagunças alheias. Uma dessas casas em que trabalhou é especialmente por 
ela rememorada: a do médico Euricledes Zerbini, que, segundo a autora, foi quem Ihe possibilitou acesso aos livros, deixando-a circular em sua biblioteca particular.

O trabalho sempre foi algo muito valorizado pela autora. Além de moldar o caráter e impedir a queda em vícios, o trabalho era para Carolina Maria de Jesus um regulador de sua imaginação, segundo ela, demasiada, que de resto não encontrava muitos meios de formalização:

Dei-me bem catando papel porque estou sempre andando. [...] que quando percibi que eu sou poetisa que fiquei triste porque o excesso de imaginação era demasiado.

[...] Eu iduquei imensamente meu cérebro. Não deixei as ideias dominar-me (Jesus, 1996a, p. 84).

Em 1948, grávida de um marinheiro português que a abandonou, não encontrou alternativa, senão a favela do Canindé, visto que havia sido despedida da casa de família onde trabalhava. Carolina construiu com as próprias mãos o barraco que iria abrigá-la junto ao seu primogênito e aos dois filhos que viriam mais tarde. Viveu às margens do Tietê e sobreviveu recolhendo das ruas e do lixo matérias para garantir sua sobrevivência - ferros e papéis que trocava por dinheiro, cadernos usados onde escrevia. Só saiu de lá quando publicou seu diário, em 1960.

A favela do Canindé tornou-se destino para Carolina Maria de Jesus por duas razões específicas: primeiro, devido às dificuldades de aceitação nos empregos em casa de família que a maternidade ocasionara; segundo, pelo contexto de negação ao direito à moradia de que a população pobre paulistana de forma estrutural era (e é) vítima ${ }^{11}$.

As biógrafas da autora nos informam que, logo em seus primeiros dias na nova cidade, Carolina Maria de Jesus passa a modificar as aspirações que cultivava em relação à "cidade favo de mel" ante a experiência da realidade urbana na capital:

Nos dias que se seguiram, depois de procurar as amigas que lá estavam, ficou
sabendo que a maioria das pessoas que vira eram operários das fábricas situadas no
centro, não longe da Estação da Luz. lam, quase todos, a pé para o trabalho:
homens, mulheres e crianças. Não demorou também a conhecer o lugar em que
moravam famílias inteiras, em pequenos cubículos alugados em alguma das
inúmeras habitações coletivas centrais. [...] Ao lado de pastagens de vacas, avenidas
com construções ricas eram interrompidas por barrancos, entre os quais casebres

11 Tendo como apoio teórico os trabalhos do sociólogo Lucio Kowarick, as biógrafas de Carolina assertam: "Naqueles anos 40, o número de habitantes de São Paulo ultrapassou dois milhões, o dobro da década anterior. O principal problema da cidade era a habitação. Para os pobres, além do cortiço, habitação predominante da classe trabalhadora até a década de 1950, a outra solução era a autoconstrução na periferia, atrelada à forte especulação imobiliária e à alteração do sistema de transporte, com a criação de linhas de ônibus, que passaram a formar uma malha viria espalhada e flexível, facilitando ainda mais a industrialização" (Castro \& Machado, 2007, p. 31). 
de estrutura de bambu, moradia de famílias pobres e negras, erguiam-se em meio a bananeiras, torrentes lamacentas e esgotos a céu aberto. [...] Aos olhos de Carolina, esses espaços tão desiguais eram desafiantes e, como ela própria, ambíguos e contraditórios [...] Não foi São Paulo que a fez tão geniosa e instável. Esses atributos já haviam viajado com ela [...] Com esse gênio, não custou a Carolina perder seu primeiro emprego, na casa dos patrões com quem viajara [...] Nos tempos que se seguiram, fez amizade com os colegas do Albergue Noturno, da sopa da Sinagoga da Rua Casemiro de Abreu, do pão da Igreja Imaculada Conceição [...] Encontrou outro emprego de doméstica. Mas nunca lhe agradou limpar a sujeira dos patrões. Gostava de sair à noite, de namorar, dançar, cantar, declamar. [...] Acabava desempregada de novo, no abrigo noturno, na fila da sopa e do pão. [...] Conheceu por dentro a vida dos cortiços [escreve sobre ela no romance Pedaços da fome, publicado em 1963] [...] como de resto dos habitantes de São Paulo na década de 1930 [...] morou também "num cubículo sórdido da antiga favela dos baixos do viaduto Santa Ifigênia" e dormiu sob os pórticos dos grandes prédios. Mas nada a cansava naqueles primeiros anos, nada a dissuadia de continuar na grande cidade que a aceitara (Castro \& Machado, 2007, p. 25-28. Colchetes meus).

A trajetória ímpar de Carolina Maria de Jesus foi profundamente marcada pela relação visceral que a autora estabeleceu com a palavra escrita. O diário Quarto de despejo, seu livro de maior circulação, não é um diário íntimo, no sentido estrito de guardar anotações de estados de alma. No entanto, é na palavra escrita que Carolina tece e trama um espaço para sua constituição subjetiva. Para Lejeune, o diário guarda diversas utilidades, como conservar a memória; sobreviver; desabafar; conhecer-se; deliberar; resistir; pensar, e finalmente, escrever:

Mantém-se enfim um diário porque se gosta de escrever. É fascinante transformarse em palavras e frases e inverter a relação que se tem com a vida ao se autoengendrar. Um caderno no qual nos contamos é uma espécie de corpo simbólico que, ao contrário do corpo real, sobreviverá (Lejeune, 2008, p. 264).

Em Carolina Maria de Jesus a origem dessa patente relação com a palavra fulgura construída para o leitor em Diário de Bitita, onde se lê uma explicação posicionada na voz socialmente legitimada de um médico espírita respeitado em Sacramento, sua cidade natal. A relação com a palavra é afirmada como parte inerente de seu ser, imanente no tempo:

Minha mãe pegou-me e levou-me ao médico espírita, o senhor Eurípides Barsanulfo. (...) Minha mãe queixou-se que eu chorava dia e noite. Ele disse-lhe que o meu crânio não tinha espaço suficiente para alojar os miolos, que ficavam comprimidos, e eu sentia dor de cabeça. Explicou-lhe que, até os vinte anos, eu ia viver como se estivesse sonhando, que a minha vida ia ser atabalhoada. Ela vai adorar tudo que é belo! A tua filha é poetisa; pobre Sacramento, do teu seio sai uma poetisa. E sorriu (Jesus, 1986, p. 71).

A revelação do inevitável destino de poetisa partindo de uma figura de autoridade é narrada por Carolina Maria de Jesus como fato real, acontecido de verdade. A veracidade do diagnóstico do médico, explicado à mãe de Carolina, no entanto, não é o que mais importa, considerando-se que a memória é menos conservação do passado e mais reconstrução dele: 


\begin{abstract}
Na maior parte das vezes, lembrar não é reviver, mas refazer, reconstruir, repensar, com imagens e ideias de hoje, as experiências do passado, "tal como foi", e que se daria no inconsciente de cada sujeito. A lembrança é uma imagem construída pelos materiais que estão, agora, à nossa disposição, no conjunto de representações que povoam nossa consciência atual. (...) O simples fato de lembrar o passado, no presente, exclui a identidade entre as imagens de um e de outro, e propõe a sua diferença em termos de ponto de vista (Bosi, E. 1999, p. 55).
\end{abstract}

Mesmo assim, o tom profético que caracteriza a fala de Eurípedes Barsanulfo médico espírita, médium famoso e também vereador em Sacramento, diversas vezes rememorado por Carolina - parece revelar que somente uma metafísica explicaria a sua formulação como autora literária, como se, àquela altura, ela só pudesse vir a sê-lo com esta autorização. Isto diz muito, em suma, visto que, historicamente, no nosso espaço nacional, o marginalizado, quando fala, fala quase sempre mediado por outra instância.

O domínio da palavra construído como algo quase inerente à natureza da autora e autenticado pela voz de personagens de autoridade - o médico espírita e a mãe - é uma estratégia reveladora da busca de legitimação para o estatuto de poeta que Carolina Maria de Jesus reivindicava para si. Este estatuto de poeta, todavia, Ihe foi negado, por exemplo, pelo editor Audálio Dantas, conforme ele o fez no prefácio de Casa de Alvenaria, ao colocar entre aspas os outros gêneros que Carolina praticava, além da escrita autobiográfica, de forma a suspender o seu valor e relega-los ao arquivamento: "Guarde aquelas "poesias", aquêles "contos" e aquêles "romances" que você escreveu" (Dantas, 1961, s/n).

A escrita autobiográfica, por outro lado, foi valorizada pelo editor principalmente pelo caráter de denúncia coletiva, cuja representatividade documental suplantava a construção estética e a afastava da esfera do literário. Nesse sentido, a estratégia que Carolina cria ao construir suas memórias de infância em conjunção com a prática da palavra poética funciona como resposta às críticas que a consideravam "escrevinhadora" de ocasião, tendo sido engendrada após o período de sucesso que a autora experimentara, quando ela já havia sido relegada ao esquecimento do público.

Logo que Quarto de despejo foi publicado a obra e a autora foram lançadas no mercado de bens simbólicos, que colocou no centro do universo da cultura o discurso de um sujeito que estava à margem da sociedade. O texto de Carolina Maria de Jesus fez emergir a complexa problemática existente em torno da legitimidade cultural do discurso literário de autoria marginal. 
Torna-se necessário enfatizar que a autoria é que é marginal, embora o livro tenha saído por uma grande editora e se tornado destaque na imprensa, pois o que se entendia como literatura marginal no Brasil desse momento era principalmente a poesia dos anos 60/ 70, cuja geração foi marcada pela célebre frase de Hélio Oiticica: "seja marginal, seja herói". A poesia marginal não foi um movimento literário de características fechadas, mas sim uma tentativa de libertação dos modos de produção e de concretização da expressão livre. Os textos eram impressos em livretos artesanais mimeografados, com a característica do detalhe, da coloquialidade e das tiragens reduzidas, em geral distribuídos em bares e levados para as ruas e praças como meios alternativos de divulgação, por isso, tal geração ficou conhecida como "geração do mimeógrafo". Carlos Alberto Messeder Pereira afirma:

O final dos anos 60 e início dos 70 viram surgir uma série de publicações que, se comparadas com os produtos literários dos anos anteriores, apresentavam particularidades bastante significativas. As pessoas responsáveis por sua produção não necessariamente se pensavam enquanto 'produtores literários'[...] Que se pode entender por 'poesia marginal'? [...] Se pensarmos em termos do circuito de produção e distribuição (comercialização) dentro do qual esta poesia está inserida, o termo marginal tem aí um significado bastante preciso. Efetivamente, num sentido material e institucional, esta produção poética é marginal; isto é, tanto sua produção quanto sua distribuição se dão fora do universo das editoras e distribuidoras [...] A venda se dá geralmente, de mão em mão, sendo realizada muitas vezes pelo próprio autor ou por amigos deste e percorrendo um circuito mais ou menos fixo de bares e/ou restaurantes, portas de cinema, teatro ou mesmo universidades (Pereira, 1981, p. 16).

Neste ponto é interessante observar que a produção da Literatura Negra ${ }^{12}$, ativa nesse momento, igualmente autoeditada, produzida, distribuída e consumida de forma

12 A afirmação da literatura afro-brasileira ainda instaura grandes debates no universo da Academia. Sua negação passa pela posição da crítica e historiografia literárias "oficiais". Na História concisa da literatura brasileira, de Alfredo Bosi, por exemplo, poetas afro-brasileiros como Domingos Caldas Barbosa e Luís Gama recebem tratamento superficial. Mesmo com a obra de Bosi foi "revista e aumentada", a partir de sua 32a edição, este aspecto do texto não foi revisto. A produção literária afro-brasileira posterior à Semana de Arte Moderna é apagada, pois nenhum autor é citado. Pode-se objetar que a historiografia literária nacional sempre tem incluído Cruz e Sousa, mas quase não há menções a textos desse autor que o caracterizassem como afrobrasileiro, tais como os poemas "Escravocratas" ou "Emparedado". Poucos trabalhos críticos se voltam ao assunto no século XX. O primeiro de fôlego é A poesia afro-brasileira, de Roger Bastide, publicado em 1943. Simbiose de análise antropológica e interpretação psicanalítica, onde o autor busca "conhecer e compreender a própria alma do negro ou do mulato, para averiguar o quanto de originalidade ou de inspiração lírica pode ser atribuído ao sangue africano que lhes corre nas veias, seja puro, seja misturado a sangue europeu" (Bastide, 1983, p. 11). Em 1959 vem a público O negro na literatura brasileira, obra de Raymond Sayers traduzida por Antonio Houaiss, onde se estuda o negro muito mais como temática que como criador de literatura. Depois, um silêncio quase absoluto de trinta anos, rompido pelos ensaios de David Brookshaw, Raça e cor na literatura brasileira, em 1983, e Zilá Bernd, Negritude e literatura na América Latina, em 1987. O ano de 1988, centenário da Abolição, marcou, entre outras coisas, um súbito interesse das editoras pela questão negra, em todos os seus aspectos. Neste ano duas obras importantes para os estudos de literatura negra no Brasil foram publicadas: Poesia negra no Modernismo brasileiro, de Benedita Gouveia Damasceno, e Introdução à literatura negra, 
independente não consta no repertório analítico do que se denominou "Surto da Poesia Marginal" ou "Geração do Mimeógrafo".

Com efeito, o termo "margem" é deveras polissêmico, ou seja, em relação à geração para a qual ser marginal se tornava sinônimo de ser herói, o tipo de "margem" em questão era aquela que entendia o livro como artefato, concebido dentro de um sistema considerado marginal (produtivo, distributivo e de consumo), mas não o seu escritor, pois o criador não está à margem da sociedade, trata-se, a verdade, do oposto: ele é parte de uma camada social que usufrui de condições privilegiadas de existência, ao menos no âmbito econômico e/ou cultural. Condições essas que inclusive permitem o entendimento de seu objeto cultural como algo contracultural; que, se por um lado procura inverter a posição de sua visão social de mundo, por outro, não altera, nem pretende alterar, o seu lugar na dinâmica social. Por conseguinte, o lugar de fala de Carolina Maria de Jesus, inserido nesse contexto, se constituiu à margem do centro de poder e à margem do literário. Estar à margem não é estar fora. Ao contrário, a narrativa caroliniana é completamente contemporânea ao seu tempo e dialoga com ele.

A autoria marginal caroliniana envolveu tanto a crítica quanto a mídia em impasses interpretativos, que de resto, como veremos, se mantém ainda hoje.

Sem conseguir atinar para a particularidade da obra caroliniana, a crítica nacional perde-se muitas vezes na questão da legitimação ou não dos textos carolinianos. Escritores e críticos como Marilene Felinto e Wilson Martins veem Carolina de Jesus como um engodo. Felinto e Martins foram críticos de cultura em veículos de imprensa escrita, como Folha de São Paulo e Jornal do Brasil (Sousa, 2012, p. 75).

O impacto que o texto de Quarto de despejo causou chama a atenção para as dificuldades inerentes ao processo de reconhecimento de autores e obras situados à margem da dinâmica habitual de circulação de discursos literários. No caso de Carolina, a crítica

também de Zilá Bernd. O ensaio de Damasceno foi originalmente apresentado na Universidade de Brasília como dissertação de mestrado em 1980 (e, portanto, anterior ao estudo de Brookshaw), mas precisou esperar anos para ser publicado. O oportunismo de sua publicação em 1988 apenas comprova os mecanismos de exclusão da literatura afro-brasileira, que atingem não só as suas expressões, mas também seus discursos críticos. Na atualidade, inúmeros trabalhos críticos sobre a produção literária negra, ou afro-brasileira, emergem das universidades espalhadas pelo país. A maior visibilidade da criação literária afro-brasileira se relaciona diretamente ao próprio aumento de visibilidade da expressão política afro-brasileira, em especial a partir da fundação do Movimento Negro Unificado Contra a Discriminação Racial (1978), que mais tarde se transformaria no MNU. A virada epistemológica fundamental que a literatura negra instaura é posicionar o negro como sujeito de seu discurso, e não objeto do discurso de outros. Como, em suma, a história do Brasil fez desde o principio. 
atentou principalmente para as incorreções gramaticais de sua narrativa, reduzindo seu valor devido às rupturas com a norma culta da língua e ao mesmo tempo, condicionando o valor do texto ao testemunho e ao documento e, consequentemente, às condições sociais - de gênero, de classe, de raça, de moradia - da autora.

O texto caroliniano caracteriza-se por sua expressão mimética, ou seja, trata-se de uma trama literária cuja textura rebenta da própria vida. Portanto, é do lugar de mulher, negra, pobre e semialfabetizada que Carolina Maria de Jesus fala. No contexto brasileiro contemporâneo observa-se cada vez mais a realização literária como inscrição estética da experiência histórica dos sujeitos. Um dos resultados aparentes disso é a multiplicidade dos locais de emanação das vozes - a plurilocalidade da literatura - que pode ser literatura homoerótica, literatura feminina, literatura periférica, literatura negra ${ }^{13}$, literatura afrofeminina, terceiro-mundista, carcerária, etc. O debate em torno da legitimidade desses campos é amplo e pode se alongar ainda por muito tempo. A auto-referencialidade explícita da primeira pessoa em textos de ficção articula índices autobiográficos na construção artística de modo a embaralhar as categorias de real e ficção. Qualquer que seja o lado que escolhemos para olhar a problemática questão em torno do lócus de enunciação de textos literários torna-se cada vez mais ilusório afirmar que "não importa quem fala", pois todo e qualquer discurso vem de algum lugar no tempo e no espaço.

No entanto, essa reflexão é um tanto diversa do que ocorreu com Carolina Maria de Jesus, pois no caso da autora, a crítica ao seu texto, em que se articulam lugares específicos de inscrição, tornou-a refém desses mesmos lugares, encerrando sua construção literária a um círculo delimitado de significação: embora Carolina tenha se distanciado, pela escrita, do lugar de subalternidade, a favela jamais sairia de seus escritos, mesmo quando eles tratavam de assuntos outros, permanecia sendo a "escritora favelada".

A escritora e jornalista pernambucana Marilene Felinto considera Carolina Maria de Jesus e sua obra um "equívoco" fabricado pela mídia:

É claro (e deveria ter sido na época) que aqueles manuscritos encontrados na favela não têm qualquer valor literário, porque não transcendem sua condição de biografia

\footnotetext{
${ }^{13}$ Em geral os termos literatura negra; literatura afro-brasileira e literatura afrodescendente são utilizados pelos críticos e por escritores. Uma possível diferença pode ser essa, conforme Maria Nazaré Soares Fonseca (2006): literatura negra: resignificação do termo negro, que historicamente em nossa sociedade se configurou como termo negativo; literatura afro-brasileira: fortalece a ideia da criação literária dos negros com a matriz africana. literatura afrodescendente: duplo movimento - constituição de uma visão vinculada às matrizes africanas e busca por traduzir as mutações inevitáveis que essas heranças sofreram na diáspora.
} 
da catação de papel e de feijão (quando havia) no cotidiano de uma favela. Os textos teriam no máximo valor documental, de interesse sociológico - o "caso Carolina" talvez aponte para mecanismos de ascensão social possíveis na realidade de injustiça socioeconômica brasileira -, antropológico ou mesmo psicológico, em se considerando novamente o "caso Carolina" como um de compulsão para a escrita, necessidade da arte ou coisas do gênero (Felinto, 1996).

Se para a jornalista os textos não são literatura, tendo apenas "valor documental", é relevante questionar, afinal, em quais bases valorativas se apoiam as definições que afirmam um texto como literário ou não. O juízo valorativo de Felinto parece dialogar com as concepções de Leyla Perrone-Moisés, defendidas em seu Altas Literaturas. Neste ensaio a crítica lamenta o fato de que o suposto consenso que teria existido ao longo do século XX em torno do cânone modernista estaria dando mostras de debilidade. A ensaísta, então, assume que haveria "alguma coisa fora do lugar, ou seja, que algo de novo estaria ocorrendo no que se refere ao gosto que preside a produção e a leitura dos textos literários" (Perrone-Moisés, 2003, p. 175-176). Embora tomando de forma negativa a "mudança" que constata, admite que a nova reconfiguração da cena literária e cultural repercute no cânone literário. A grande dúvida da crítica parece concentrar-se, então, no alcance de tal reconfiguração. Ou seja, Perrone-Moisés preocupa-se em entender se a movimentação das peças no tabuleiro do "jogo literário" atingiria a escrita e a leitura do "historicamente restrito" grupo de pessoas ligadas a tais atividades ou se, por outro lado, existiria apenas uma discussão fechada ao âmbito acadêmico.

Para Felinto, "a academia tenta, mas não consegue dar estatuto literário a Carolina de Jesus" (Felinto, 1996, ênfase minha), admitindo, conscientemente ou não, que um valor é sempre o resultado de uma luta (Avelar, 2009) e o estatuto literário algo atribuído às obras por instâncias legitimadoras, no caso a Academia, e não imanentes a elas. A justificativa de Felinto para a negação de "qualquer valor literário" para "aqueles manuscritos encontrados na favela" é o de que os mesmos não "transcendem sua condição de biografia", o que no mínimo revela uma postura demasiadamente conservadora em relação ao gênero, visto que a escrita autobiográfica não exclui de antemão a construção estética, ao contrário, por vezes sustenta-se nela e, por outro lado, abre a complexa questão acerca da noção de "valor" que conserva em pilares demasiadamente questionáveis o caráter de "bom" ou "ruim" com o qual em geral se rotulam textos literários.

Toda concepção de valor, isto é, de que certos textos são melhores do que outros, "mais literários" de que outros, encerra uma problemática fundante. Quem diz que um texto 
é melhor? Que base social/ideológica/política sustenta os processos históricos através dos quais certos valores foram atribuídos a determinados textos e não a outros? Quem definiu os critérios? De fato, se trata de uma discussão deveras profunda envolvendo, em suma, a configuração dos cânones literários nacionais. Se considerarmos que todo valor é resultado de uma intrincada rede de fios - como a crítica literária acadêmica, as editoras, os livros didáticos, os currículos dos cursos de letras, os prêmios literários, a imprensa, etc. - que se articula e se retroalimenta para manter a posição segundo a qual apenas alguns agentes valoradores são qualificados para dizer qual texto é bom e qual não é; assumiremos que todo valor é resultado de conflitos, choques e disputas de poder atuando no campo simbólico e, portanto, sempre construído socialmente em articulação com forças econômicas, com pressupostos de gênero, etnia e território, sendo, por isso, contingente e nunca imanente à obra, pois uma obra nunca é boa simplesmente porque é boa, visto que a literatura não é um elemento da natureza, a-histórico.

Isto posto, a afirmação de Felinto de que a academia não consegue dar estatuto literário a Carolina de Jesus, apenas reitera o poder da academia enquanto agente valorador, e nada diz a respeito dos textos de Carolina Maria de Jesus.

Por seu turno, o crítico Wilson Martins questiona a própria autoria da obra, atribuindo-a ao editor Audálio Dantas:

\footnotetext{
Tudo indica que a editoração de Audálio Dantas foi muito além da "excessiva presença" que admite na preparação do texto. Cortes, seleções, vocabulários e até, penso eu, anotações inteiras, sugerem que é tempo de lhe restituir a autoria do "diário de uma favelada" (Martins, 1993).
}

Acerca da dúvida levantada por Martins a respeito da autoria, uma resposta, assinada por Ferreira Gullar, já havia sido impressa na orelha de Casa de Alvenaria, onde se reúnem "opiniões sobre Quarto de Despejo":

\footnotetext{
Tampouco têm razão os que não acreditam na autenticidade do livro e desconfiam de que tudo não passa de uma chantagem. Basta a leitura de alguns trechos do livro para mostrar que essa hipótese é absurda: só um gênio seria capaz de colocar-se no lugar de uma favelada e fingir a vivência dos episódios que ela narra. (In: Jesus, $1961, \mathrm{~s} / \mathrm{n})$.
}

A leitura de Gullar ampara-se na questão da autenticidade, que de resto representa o tom geral da recepção do livro. Na mesma orelha, a avaliação do jornalista e escritor carioca Vivaldo Coaracy vem coroar tal veredito: "Não é obra literária; não é simples depoimento; não é mera denúncia. É um documento. E como tal, tem que ser levado a sério" (In: Jesus, $1961, \mathrm{~s} / \mathrm{n})$. 
A pesquisadora Elzira Divina Perpétua, que entrevistou o jornalista Audálio Dantas e anexou a entrevista em sua tese ${ }^{14}$, deixa ver o posicionamento editorial deste em relação à produção variada de Carolina:

Audálio Dantas afirma que, entre os vários tipos de escrita, o diário, que preenchia apenas dois dos 27 cadernos originais, era a única das formas que ele considerava ter "força narrativa", "o resto eram outras coisas, romance, conto, poesia, provérbios. Então, depois que eu retomei o contato com ela, eu lhe disse o seguinte: olha, a coisa que você faz é isto" (Perpétua, 2000, p. 55. Ênfase minha).

Carolina Maria de Jesus se entendia e se afirmava poeta. Como bem observado pelo pesquisador José Carlos Sebe Bom Meihy, responsável por importantes estudos recentes dedicados a autora: "Carolina foi e era por autodefinição poeta. Sequer dizia-se poetiza. Sem entender o significado disto, tudo que for dito sobre ela soará pouco e, mais que incompleto, vazio" (Meihy, 1996, p. 17). Ser poeta, do ponto de vista da autora, era - para além de escrever poemas - vocação, convicção, munição e destino. Contudo, os valores atribuídos ao seu texto negavam-Ihe a possibilidade de sê-lo. Assim como Platão no livro X da República expulsou o poeta da polis, Carolina Maria de Jesus deveria ficar restrita à favela e fora do espaço de formulação subjetiva, cabendo-lhe apenas documentar o lado invisível da cidade para deleite dos membros "legítimos" da São Paulo moderna.

O estatuto de poeta que Carolina dimensionou para si colocava a autora em uma condição de constante diálogo com a sua experiência social:

6 de novembro de 1959: Catei os metaes e voltei para a favela - Que pêso! Tinha a impressão que era são Cristovam carregando o menino jesus. Quando cheguei estava exausta e transpirando. Eu sempre ouvi dizer que os póetas viviam na ociosidade. Era os poetas brancos será que a sorte do póeta negro é negra igual a sua pele? (Perpétua, 2000, p. 335).

No entanto, justamente devido à novidade que a narrativa de uma autora com tal experiência social e capacidade expressiva representava no cenário das letras nacionais, os traçados do livro publicado foram determinados a partir de modos de leitura específicos. No caso de Quarto de despejo a criação e a produção se mesclam, visto que paralelamente à fabricação de seu objeto (o livro) e de sua imagem (da escritora favelada) Carolina permanecia escrevendo cotidianamente seu diário, e, ao que tudo indica, o editor Audálio Dantas ocupava o lugar privilegiado de leitor concreto e imediato:

Eu estava escrevendo. Ela perguntou-me:

\footnotetext{
${ }^{14}$ Manuscritos originais de Carolina Maria de Jesus, cujos trechos citaremos aqui, também foram publicados como anexo nesta tese.
} 
-Dona Carolina, eu estou neste livro? Deixa eu ver!

-Não. Quem vai ler isto é o senhor Audálio Dantas, que vai publicá-lo (Jesus, 1960, p. 138).

Os modos de leitura operantes são construídos já na edição do livro e direcionam o leitor para uma "leitura sociológica da obra" (Perpétua, 2000, p. 21). A partir da análise do paratexto de Quarto de Despejo, principalmente o prefácio de Audálio Dantas e as orelhas das edições posteriores, é possível antever a construção dos valores que deveriam nortear a leitura da obra, todos eles convergindo para a ideia do texto como representação coletiva da miséria. 


\section{2 - Margens do texto: Quarto de despejo e a representação coletiva}

Esquentei o arroz e os peixes e dei para os filhos. Depois fui catar lenha. Parece que eu vim ao mundo predestinada a catar. Só não cato a felicidade.

- Carolina Maria de Jesus

Segundo Wander Melo Miranda, "parece não haver motivo suficiente para uma autobiografia se não houver uma intervenção, na existência anterior do indivíduo, de uma mudança ou transformação radical que a impulsione ou justifique" (Melo Miranda, 1992, p. 31). No caso de Quarto de Despejo, embora Carolina Maria de Jesus já praticasse a escrita há muito tempo, um fato determinante ocorrera em 1958: conheceu o jornalista Audálio Dantas na favela do Canindé, que se encantou com a descoberta dos seus escritos, incentivou a composição do diário, fez publicar e lançou no mercado o diário de uma favelada.

A história da publicação do diário de Carolina Maria de Jesus é também a história do seu editor, que ficou internacionalmente conhecido à época como "o descobridor da escritora favelada" ${ }^{15}$. A ele deve-se a seleção dos trechos publicados, o prefácio do livro e a preparação da recepção, estrategicamente construída em veículos midiáticos de prestígio no período: o Jornal Folha da Noite ${ }^{16}$ e a revista O Cruzeiro, que durante o tempo que antecedeu o lançamento levou ao público fragmentos escolhidos da obra e aspectos marcantes da história da autora.

A primeira parte de Quarto de despejo cobre um curto período que vai do dia 15 ao dia 28 de julho de 1955, com entradas diárias (exceto no dia 26, em que não há registro). Depois, salta-se para o ano de 1958, com a primeira entrada no dia 02 de maio:

2 de maio de 1958: Eu não sou indolente. Há tempos que eu pretendia fazer o meu diário. Mas eu pensava que não tinha valôr e achei que era perder tempo. Eu fiz uma reforma em mim. Quero tratar as pessoas que eu conheço com mais atenção. Quero

\footnotetext{
${ }^{15}$ Repórter social, Audálio Dantas concentrou sua carreira jornalística na preocupação com a pobreza. Como presidente do sindicato dos jornalistas teve importante participação no caso Vladmir Herzog. O volume $O$ circo do desespero: coleção de reportagens (1976) reúne artigos que deixam a ver a coerência de sua trajetória profissional.

${ }^{16}$ O jornal "Folha da Noite" foi fundado em 1921, em São Paulo. Em 1925 é criada sua edição matutina, a "Folha da Manhã" e em 1949 surge a "Folha da Tarde". Finalmente, em 1960 ambos os títulos se fundem para fundar o jornal "Folha de São Paulo".
} 
enviar um sorriso amável as crianças e aos operários. Recebi intimação para comparecer as 8 horas da noite na Delegacia do 12. Passei o dia catando papel. A noite os meus pés doiam tanto que eu não podia andar. Começou a chover. Eu ia na Delegacia, ia levar o José Carlos. A intimação era para êle. O José Carlos está com 9 anos (Jesus, 1960, p. 30. Ênfase minha).

Além do intervalo temporal de três anos, as duas partes apresentam singularidades e algumas diferenças entre si. Na primeira parte do diário, centrado nos registros do ano de 1955, o tom da narrativa dilata-se numa ótica que enxerga os problemas e dificuldades principalmente a partir das questões individuais do eu que se narra. Nesse primeiro momento do diário a narrativa se concentra principalmente na vontade de mudar da favela e no desejo de tornar-se escritora, como se nota nos excertos abaixo:

Veio o peixeiro Senhor Antonio Lira e deu-me uns peixes. Vou fazer o almôço. As mulheres sairam, deixou-me em paz por hoje. Elas já deram o espetaculo. A minha porta atualmente é theatro. Todas crianças jogam pedras, mas os meus filhos são os bodes expiatorios. Elas alude que eu não sou casada. Mas eu sou mais feliz do que elas. Elas tem marido. Mas, são obrigadas a pedir esmolas. São sustentadas por associações de caridade. Os meus filhos não são sustentados com pão de igreja. Eu enfrento qualquer espécie de trabalho para mantê-los. E elas, tem que mendigar e ainda apanhar. Parece tambor. A noite enquanto elas pede socorro eu tranquilamente no meu barracão ouço valsas vienenses. Enquanto os espôsos quebra as tábuas do barracão eu e meus filhos dormimos socegados. Não invejo as mulheres casadas da favela que levam a vida de escrava indianas (Jesus, 1960, p. $17,18)$.

Vou escrever um livro referente a favela. Hei de citar tudo que aqui se passa. E tudo que vocês me fazem. Eu quero escrever o livro, e vocês com estas cenas desagradáveis me fornece os argumentos. [...] Estou residindo na favela. Mas se Deus me ajudar, hei de mudar daqui. Espero que os políticos estingue as favelas (Jesus, 1960, p. 21).

Eu não tenho homem em casa. É só eu e meus filhos. Mas eu não pretendo relaxar. O meu sonho era andar bem limpinha, usar roupas de alto preço, residir numa casa confortável, mas não é possivel. Eu não estou descontente com a profissão que exerço. Já habituei-me andar suja. Já faz oito anos que cato papel. O desgosto que tenho é residir em favela (Jesus, 1960, p. 23).

(...) Passei o resto da tarde escrevendo. As quatro e meia o senhor Heitor ligou a luz. Dei banho nas crianças e preparei para sair. Fui catar papel, mas estava indisposta. Vim embora porque o frio era demais. Quando cheguei em casa era 22,30. Liguei o rádio. Tomei banho. Esquentei a comida. Li um pouco. Não sei dormir sem ler. Gosto de manusear um livro. O livro é a melhor invenção do homem (Jesus, 1960, p. 25, 26).

... Seu Gino veio dizer-me para eu ir no quarto dêle. Que eu estou the despresando. Disse Ihe: Não! É que eu estou escrevendo um livro, para vendê-lo. Viso com êsse dinheiro comprar um terreno para eu sair da favela. Não tenho tempo para ir na casa de ninguém. Seu Gino insistia (Jesus, 1960, p. 28, 29). 
A retomada da escrita do diário após esse primeiro momento deve-se ao encontro com o jornalista, que a incentivara a não abandoná-lo, pois ele identificara imediatamente o valor latente da narrativa. A partir de então, os registros iniciados no ano de 1958 ultrapassam a narrativa centrada no indivíduo Carolina e passam a engendrar uma enunciação cujo caráter concentra-se mais na crítica social da favela e da cidade. Nesse sentido, embora a separação seja sutil, tendo em vista que o tom mais íntimo permanece nos registros da segunda parte, ocorre uma oscilação que vai do caráter mais pessoal e individual para o olhar mais afeito à crônica, vislumbrando o social. É nessa segunda parte da narrativa diarística, que vai do dia 02/05/1958 ao dia 01/01/1960, que surgem com elevada força dois elementos de destaque no texto e que passam a acompanhar toda a trajetória discursiva da autora, são eles: a fome e a cidade.

O encontro do jornalista Audálio Dantas com Carolina Maria de Jesus, embora fruto do puro acaso, estava dentro da paisagem social que a cidade de São Paulo apresentava no meio século XX. A imprensa se formava, no dizer de Carlos Sebe Bom Meihy, por "jornalistas sensíveis, que por sua vez falavam para um mundo sensível às transformações". Elzira Divina Perpétua em sua tese de doutoramento (Perpétua, 2000), afirma:

\begin{abstract}
A acolhida de Quarto de despejo no Brasil fora precedida pelo recebimento da nascente crônica urbana e do jornalismo investigativo - a chamada reportagem -, que apontavam as disparidades entre o progresso material do país e o empobrecimento da população. A cidade de São Paulo era então o centro de maior convergência de problemas sociais motivados pelo desenvolvimento industrial acelerado. A concentração de riquezas fazia da capital paulista uma terra de contrastes, diferente dos outros centros urbanos brasileiros. Nesse ambiente, a reportagem, ao exibir o outro ângulo do desenvolvimento, porque levava em conta o dia-a-dia dos miseráveis e anônimos vindos de todas as partes e espalhados pelo espaço urbano, ganhava sentido político (Perpétua, 2000, p. 50).
\end{abstract}

A ida de Audálio Dantas à favela do Canindé, ao final de abril de 1958, cumprir uma pauta que ele próprio havia proposto ao jornal Folha da Noite, rendeu mais que uma reportagem. No prefácio de Quarto de despejo assim o repórter narra seu encontro com Carolina:

Cheguei lá, repórter, para ver o que disseram uns da favela sôbre umas balançasbrinquedo-de-menino que a Prefeitura mandou botar na favela. O que disseram uns da favela era verdade: Os brinquedos dos meninos, os grandes tomaram. (...) Carolina estava perto da balança dos meninos (...). E protestava, aonde já se viu uma coisa dessas, uns homens grandes tomando brinquedo de criança! Carolina, negra alta, voz forte, protestava. Os homens continuavam no bem-bom do balanço e ela advertiu: - deixe estar que eu vou botar vocês todos no meu livro! Aí eu perguntei: que livro? Então ela me respondeu: - O livro que eu estou escrevendo as coisas da favela. Fui ver o livro (...) ninguém podia melhor do que a negra Carolina escrever histórias tão negras. (...) foi por isso que eu disse assim para Carolina Maria de Jesus, 
lá mesmo, na horinha que lia trechos do seu diário: - Eu prometo que tudo isto que você escreveu sairá num livro. (Dantas, 1960, p. 5-6, ênfases do original).

O encontro com Carolina modificou a pauta do repórter: em vez de uma matéria sobre a vida numa favela típica de São Paulo ${ }^{17}$, produziu o primeiro texto que tornava pública a figura da favelada que escrevia, vinculando o nome de Carolina Maria de Jesus ao testemunho legítimo da miséria vivenciada na favela. Ao fazer isso, Audálio Dantas lança mão de um recurso metonímico, convertendo um indivíduo singular (Carolina Maria de Jesus) no retrato de um ambiente inteiro (a favela) e acionando as experiências sobre tal ambiente que embora vivenciadas por diversos sujeitos, são construídas no texto de um ponto de vista particular e subjetivo - em um documento de caráter comprovativo e inquestionável. Nesse movimento, a construção autoral caroliniana dilui-se em discurso que, por meio das estratégias editoriais empregadas, pretende alcançar representatividade coletiva.

Quarto de despejo começa a surgir para o público em uma reportagem de página inteira publicada em nove de maio de 1958, no jornal Folha da Noite - "O Drama da Favela Escrito por uma Favelada: Carolina Maria de Jesus Faz um Retrato sem Retoque do Mundo Sórdido em que Vive". A sinopse da matéria, localizada no centro da página, apresenta em resumo os tópicos que a reportagem aborda:

É apanhadora de papel, passa fome com os filhos pequenos, mora num barracão infecto, mas sabe "ver" além da lama do terreiro e do zinco da favela - A miséria desperta o espírito - Cadernos cheios de "poesias", "contos" e "romances" Peregrinação (inútil) pelas editoras - A narrativa da vida na favela, num impressionante "diário" - Repórteres das FOLHAS editarão Carolina. ${ }^{18}$

A matéria, composta ainda por quatro fotografias, traz descrições do cotidiano na Canindé e índices biográficos de Carolina, destacando a sua singularidade frente aos demais favelados:

Ela sabe "ver" alem da lama do terreiro, da nudez das crianças, da sordidez da vida. Só por isso ela é diferente dos outros favelados: vive integralmente a miséria da favela, mas tem o seu "mundo interior", às vezes feliz, outras vezes profundamente angustiado. E quando entra no seu "mundinho" não esquece o outro que a cerca, miserável, cruel, sórdido, que é por ela "biografado" (Dantas, 1958).

\footnotetext{
${ }^{17}$ Em entrevista a Elzira Divina Perpétua, Audálio diz: "eu peguei aquela favela, a favela do Canindé, por algumas razões. Primeiro porque lá era isolado, não era um fenômeno assim alastrado como é hoje em dia aqui e como foi no Rio de Janeiro sempre. Era uma favela relativamente pequena, na beira do rio, uma coisa típica de São Paulo, à beira do rio Tietê" (Perpétua, 2000, p. 52).

18 DANTAS. O drama da favela escrito por uma favelada: Carolina Maria de Jesus faz um retrato sem retoque do mundo sórdido em que vive. Folha da Noite, nove de maio de 1958.
} 
O eixo principal da matéria está focado no fato de que Carolina escreve:

\begin{abstract}
Biografia é bem o termo para o que Carolina Maria de Jesus faz em relação à favela em que vive. Em seu barracão há quase uma dezena de cadernos, nos quais ela escreveu o dia-a-dia daquele aglomerado humano. Com sua caligrafia nervosa, ela conta coisas que nenhum escritor do mundo seria capaz de contar com tanta propriedade; traça um retrato sem retoques da favela, que aparece nítida, impressionantemente revelada em um "diário", em quadrinhas que são quase notícias de jornal ou em "contos" e "romances" cujos personagens fervilham sob telhados de lata e zinco (Dantas, 1958).
\end{abstract}

Nesta primeira reportagem a escrita ficcional caroliniana é citada em paralelo com o diário na construção da "biografia" da favela. Tanto os "contos", quanto os "romances", as quadrinhas e as "poesias" constituiriam o "mundinho" da autora, do qual ela partiria para biografar o "outro que a cerca": o da favela, que aparece como retrato nítido, sem retoques, isto é, sem elaboração artística. Alguns versos de Carolina são citados na matéria, destacando o seu périplo em busca de publicação para os seus escritos:

\author{
Não digam que eu fui rebotalho \\ Que vivia à margem da vida \\ Digam que eu procurava trabalho \\ Mas fui sempre preterida \\ Digam ao meu povo brasileiro \\ Que o meu sonho era ser escritora, \\ Mas eu não tinha dinheiro \\ Pra pagar uma editora \\ (Dantas, 1958).
}

Mas a maior parcela do texto é dedicada a propalar excertos do diário, afirmando já nesse momento inicial o lugar de Carolina Maria de Jesus como cronista de seu cotidiano. Dantas considerou o texto uma reportagem e chamou-a de colega sua de profissão em alguns momentos. Por este motivo, dedicou-se à leitura mais atenta do diário em detrimento dos outros textos, "porque eu via que o diário, além da força descritiva, ele é depoimento" (Perpétua, 2000, p. 55). A matéria repercutiu e o jornalista passou a valorizar mais o texto diarístico, incentivando Carolina a dedicar-se com mais afinco à sua elaboração: "E então depois da reportagem eu comecei a ler com uma atenção maior os cadernos" (Perpétua, 2000, p. 55).

Audálio Dantas, peça fundamental na assunção da carreira de Carolina Maria de Jesus, é jornalista e não crítico literário. O seu ponto de vista, impresso na edição, estava relacionado com a valorização da carga de realidade, autenticidade e objetividade - pontos comuns no discurso jornalístico - e não na construção da intencionalidade estilística e reflexiva do texto. Para ele tratava-se de: 
Depoimento de alguém que, vivendo em um meio marginal, podia contar o que era aquele meio melhor do que qualquer um que fosse de fora. Este contar das coisas da favela possuía uma inegável expressão literária. Não chegava a ser uma obra literária propriamente dita, mas possuía momentos de grande força descritiva, de criação de imagens (in: Meihy, 1994, p. 102).

Embora afirmando a "inegável expressão literária" do texto, em consequência imediata da repercussão desta primeira reportagem o desenho do diário publicado vai se engendrando a partir de uma linha discursiva que privilegia detalhes da experiência favelada na organização dos fragmentos que são publicados sob o formato de livro.

Mais de um ano após essa primeira reportagem, em 20 de junho de 1959 Dantas publica uma segunda, dessa vez na revista O Cruzeiro, da qual ele tornara-se editor chefe, com o título "Retrato da Favela no Diário de Carolina" e com o subtítulo "A fome fabrica uma escritora". Na sinopse já se nota a valorização da escrita diarística e a subvalorização da ficcional:

Escreve versos ingênuos, enche cadernos de sonhos. Mas não se limita a sonhar. Não esquece o mundo sórdido que a cerca, a miséria de seus irmãos favelados - a sua própria miséria. Maria Carolina (sic) tem em seu barraco uma dezena de cadernos cheios da vida da favela, um diário fiel, sem artifícios, do dia-a-dia de sua comunidade marginal. Há longos anos, ela vem escrevendo a respeito de seu pequeno mundo, "fotografando" misérias, desencantos e, até, pequenas alegrias (Dantas, 1959, p. 92, 93).

No parágrafo inicial da matéria já está disposto o viés jornalístico atribuído ao testemunho, enfatizando o que fora anteriormente afirmado na primeira reportagem:

O "diário" de Carolina é reportagem autêntica, retrato sem retoques. Carolina Maria de Jesus faz reportagem diária sobre a favela. Reportagem vivida e sofrida. Quando fala da longa espera na "fila da água" (há apenas uma torneira para o abastecimento de toda a população) é com o conhecimento de causa de quem permanece horas sentada numa lata, aguardando a vez de chegar à torneira. E quando escreve, com sua caligrafia nervosa, que não tem o que comer, é com o desalento de quem está de estômago vazio, e sem perspectiva imediata de enchê-lo (Dantas, 1959, p. 92).

Os textos de ficção aparecem nesta matéria definidos como escrita de devaneio, funcionando para Carolina simplesmente como possibilidade de fuga de sua realidade adversa. Enfatiza-se a busca empenhada da autora em publicar estes textos, para logo em seguida reafirmar a autenticidade incomparável do texto do diário, cuja força nenhum outro cronista poderia alcançar: "É no 'diário', porém que se encontra a autêntica Carolina Maria de Jesus, favelada falando da favela". A reportagem é repleta de trechos do diário, dez no total, que na realidade ocupam a maior parte do espaço da matéria. Após essa segunda reportagem muitas outras se seguiram na imprensa escrita, o que tornava a figura de Carolina Maria de 
Jesus já conhecida do público quando o livro finalmente foi publicado, mais de um ano depois.

A própria autora, nos espaços em que circulava, se incumbia de divulgar as reportagens que saiam a seu respeito, falando de boca em boca e distribuindo as revistas para que as pessoas pudessem ler:

10 de junho de 1959. Na cidade eu disse para os jornaleiros que a repórtagem do $\mathrm{O}$ Cruzeiro era minha. Como eu estava limpa não acreditaram. pensei: sera que eu tenho que andar sempre suja? Fui receber o dinheiro, e avisei ao tessoureiro que eu estava no O Cruzeiro. Quando eu disse que estava no O Cruzeiro varias pessôas olhou-me: pensei estas pessoas ão de comprar O Cruzeiro. [...] Quando voltei para a favela passei no emporio do senhor Eduardo Chola Móstrei-Ihe a revista para os opérarios do Frigorifico Jardim (Jesus, 1960, p. 164).

Carolina também discutia a repercussão de sua imagem como escritora em consequência da publicação premente do livro:

30 de outubro de 1959. - Então a senhora vai ficar rica!

Eu gósto da minha vida como ela é Eu gósto de ser preta. eu gósto de ser pobre. A unica ambição que eu tenho na vida, é viver até criar os filhós e alfabetisa-lós - A tarde eu fui lavar róupas A mãe de Dona Adelaide estava lavando. Ela quer saber quando é que eu vou reçeber o dinheiro do livro.

- O ano que vem. Respondi mal humórada pórque já enjôei de ouvir isto. [...] Eu disse para a mãe de Dona Adelaide que eu vóu ganhar mais de 12 milhões nos livros. - para que tanto dinheiro?

Pareçe que o branco não gosta de ver o preto endinheirado

A senhora não admite riquêzas para o preto?

Ela não respondeu (Citado por: Perpétua, 2000, p. 326).

2 de novembro de 1959. Dórmi na grama. O sol estava quente e aqueçeu-me. Que sono gostôso! Sem os reboliços da favela. Não havia ruidós porque hoje é dia de finadós. e a cidade esta calma. sem agitação passou um repórter. parou, olhou me. A Vera disse-Ihe:

- Mocô! Tira o nosso retrato. Eu estava com mêdo d ela dizer: A mamãe é póetisa! Dei graças a Deus quando êle seguia. porque eu estava com tanto sono. - Se eu pudesse passar o dia ali... [...] Surgiu uma preta velha condusindo-me uma pretinha disse ser sua neta. Começamos a conversar... [...]

Eu ouvi dizer que tem uma preta que cata papel e escreve. [...]

- A Vera ia dizer: é a mamãe que escreve: fiz um sinal para ela calar-se (Citado por: Perpétua, 2000, p. 327).

12 de novembro de 1959: Eu sóu poetisa e pretendo escrever muitos livros. - A senhora já me viu no O Cruzeiro? (Citado por: Perpétua, 2000, p. 328).

14 de novembro de 1959: Agradeci e voltei para fechar a porta e pegar â revista O Cruzeiro para mostrar ao farmaceutico O senhor Jesus. Atual. dono da farmacia jaruá. porque êle esta duvidando da minha sanidade. Devido eu falar o classico e andar tão suja. Vou mostrar-lhe a revista para desfazer as duvidas. E pórisso que eu digo que o jornal favoreçe - Fui na farmacia, comprei os remedios e mostrei-Ihe a revista Ficaram adimiradós.

[...] parei para conversar com uma senhora que resside na esquina na rua Araguaia e mostrei-Ihe a reportagem do Audálio e a reportagem do senhor Moacir górge no Diario Ela adimirou - Disse-me que ouviu dizer que escrevo mas, não acreditou 
pórque êles pensam que quem escreve e so as pessôas bem vistidas. Na minha opinião, escreve quem quer (Citado por: Perpétua, 2000, p. 328).

O texto de Carolina Maria de Jesus estabelecia uma situação editorial inédita e criava um novo nicho no mercado literário. Com efeito, na orelha da primeira edição de Quarto de despejo, o editor Paulo Dantas explica que o livro fora:

Selecionado para a abertura de uma nova coleção, que sob o euclidiano batismo de
'Contrastes e Confrontos' oferecerá ao grande público uma visão múltipla e
revolucionária das vivências humanas, populares, sociológicas e culturais do Brasil.
Carolina Maria de Jesus, que da noite para o dia tornou-se a escritora revelação-
popular do ano, carreando para sua figura e para seu forte temperamento artístico
as atenções e as simpatias da Nação, escrevendo 'preto no branco' deflagra uma
revolução nos quadros editoriais e intelectuais da hora presente (Dantas, P. in:
Jesus, 1960, s/n).

De fato, a orelha do livro preparada por Paulo Dantas é um primeiro comentário crítico sobre a obra. Enfatizando o que há de universal em sua matéria, o texto de Carolina é apresentado por ele nestes termos:

Literatura da favela escrita pelo próprio favelado, eis o sentido sincero do livro
escrito pela trapeira mineira, radicada em São Paulo (...). Só mesmo ela, com sua
pungente experiência, podia ter escrito êste livro. O seu verbo vem na ordem direta
da miséria, recebe e transmite a carga de sofrimentos anônimos e populares, sendo
julgamento e protesto, ao mesmo tempo, que diário e reportagem, romance e
poesia, porque neste patético livro de Carolina perpassa um particular sôpro lírico,
com invulgares clarões de beleza. Isto é que vence as formas estropiadas de sua
ortografia e de sua sintaxe primária, no livro, conservadas, pelo seu sabor e
singeleza (Dantas, P. in: Jesus, 1960, s/n).

O comentário de Paulo Dantas enfatiza a pluralidade presente na narrativa caroliniana, pois alcança e coaduna as dimensões da expressão poética e testemunhal do texto. No entanto, tal leitura não será a preponderante e o "particular sopro lírico, com invulgares clarões de beleza" será seguidamente invalidado pela crítica, comprometendo a constituição autoral ao subtrair tanto a individualidade da voz quanto a inventividade da escrita. A orelha da edição de 1983 de Quarto de desejo, feita pelo poeta carioca Fernando Py, é enfática neste sentido, ao afirmar que o livro é "um documento vivo de uma época, de uma sociedade, de um estado de coisas" (Jesus, 1983, s/n). Observa-se na definição de Py, que o gesto criador e particular que gestou a escrita é simplesmente obliterado, sendo a existência do relato atribuído tão somente à época, à sociedade e ao estado de coisas.

Os textos de apresentação que acompanham as diversas edições do diário comprometem a voz particular da autora ao qualificar seu discurso exclusivamente como a "voz do povo", "porta-voz da favela", relato feito por alguém que "ultrapassou os limites 
individuais e deu voz à coletividade miserável e anônima que habita os barracos e os vãos das pontes nas grandes cidades brasileiras" (Jesus, 1994, p. 169).

O olhar crítico e por vezes ácido de Carolina Maria de Jesus para a favela não costuma ser mencionado nos textos que a apresentam ao público, pois interessava naquele momento acentuar justamente o pertencimento da autora a esse espaço geográfico e à marca diferencial de sua extração social, o que acarretou na diluição da voz autoral em uma identidade grupal - algo, naquele contexto, profundamente questionável.

O lugar social de Carolina, bem como as características sintáticas de sua construção vocabular são dois aspectos reiteradamente ressaltados ao longo das diversas edições de Quarto de despejo, mesmo na contemporaneidade. Em 2007 a edição da Ática traz um prefácio sem indicação de autor, datado de 1993, cujo título é "Favela, o quarto de despejo de uma cidade", em que se apresentam em destaque os dizeres: "Não perca! A vida na favela do ponto de vista de quem mora nela. O retrato trágico da fome e da miséria" (Jesus, 2007, $s / n)$.

A miséria tornada espetáculo nos remete à análise de David Harvey em seu "A condição pós-moderna", lançado no Brasil em 1993, mesmo ano do prefácio: "Uma vez que os pobres ficam estetizados, a própria pobreza sai do nosso campo de visão social, exceto enquanto descrição passiva da alteridade, da alienação e da contingência no âmbito da condição humana" (Harvey, 1993, p. 301). Ao tom de espetacularização segue-se, logo abaixo, uma nota editorial em que se afirma: "Esta edição respeita fielmente a linguagem da autora, que muitas vezes contraria a gramática, mas que por isso mesmo traduz com realismo a forma de o povo enxergar e expressar seu mundo" (Jesus, 2007, s/n).

A leitura de Quarto de despejo apenas como documento, retrato sem retoque da favela, torna-se problemática, em primeiro lugar, se considerarmos o processo de compilação, seleção e edição dos manuscritos de Carolina - dispostos em trinta e sete cadernos entregues ao jornalista Audálio Dantas ${ }^{19}$, editor do diário.

O primeiro contato que o leitor tem com o diário de uma favelada - subtítulo que já introduz uma identificação social para Carolina - é mediado pela apresentação de Audálio Dantas intitulada "Nossa irmã Carolina". O prefácio - palavra latina cujo étimo praefatio, ónis

\footnotetext{
19 Do total de 37 cadernos manuscritos que Carolina entregou a Dantas, o diário preenchia apenas dois, o restante eram textos ficcionais - poemas, contos, romances e provérbios.
} 
(praefor): 'ação de falar ao princípio de' - reúne a macrofunção paratextual de apresentar uma obra escrita ao leitor, e, no caso do elaborado por Dantas, promover um modo de leitura para o diário.

O discurso de apresentação de Quarto de despejo assume a função principal de legitimação, não apenas do texto, mas, principalmente, de sua autora. Isto é, a argumentação persuasiva do prefaciador legitima a imagem da autora que se está apresentando ao público. Tratando-se Quarto de despejo de um diário, o prefácio vai certificar o leitor tanto da existência civil da autora, como do caráter verídico de seu texto, inserindo-se o nome do prefaciador como testemunho da narrativa apresentada. O texto da apresentação é estruturado em dois níveis: o primeiro nível ocupa-se em mobilizar uma imagem para Carolina e para a favela, de modo a presentificá-los ou torná-los concretos em sua existência até ali ignorada pela cidade. Foi preciso tornar reais a autora e a matéria da narrativa para leitores que desconheciam seu universo social.

O "efeito de real", segundo Roland Barthes, tem na descrição detalhada um apoio para criar a ilusão referencial (Barthes, 1988, p. 158-165) desse modo, a descrição é elaborada, nas obras realistas, menos como função estética e mais com uma intencionalidade retórica. Dantas alcança esse mesmo efeito pela descrição do pormenor concreto configurando um retrato minucioso da moradia, das ruas, das pessoas; compondo seu relato com fotografias de Carolina, da favela, dos moradores e dos barracos.

\footnotetext{
O barraco é assim: feito de tábuas, coberto de lata, papelão e tábuas também. Tem dois cômodos, não muito cômodos. Um é sala-quarto-cozinha, nove metros quadrados, se muito for; e um quarto quartinho, bem menor, com lugar para uma cama justinha lá dentro. A humanidade dela é esta: Carolina, Vera Eunice, José Carlos, João José e 35 cadernos. Tem mais coisas dentro dêle, que a luz da janelinha deixa a gente ver: um barbante esticado, quase arrebentando de trapos pendurados, mesinha quadrada, tábua de pinho; e fogareiro de lata e lata-de-botarágua e lata-de-fazer-café e lata-de-cozinhar; tem também guarda-comida escuro de fumaça e cheio de livros velhos; e mais: duas camas, uma na sala-quarto-cozinha e outro no quarto assim chamado. [...] Isto é o barraco dentro. O barraco fora é como todos os barracos de tôdas as favelas. Feio como dentro. As tábuas estão escuras, de velhas (Dantas, 1960, s/n).
}

O segundo nível, mais complexo, sedimenta as formas de ler o narrado, a partir da ênfase atribuída ao valor sociológico do texto e ao seu estatuto de testemunho real, posto que escrito pelo sujeito da experiência.

Encadeado em quatro partes, o prefácio instaura um quadro social para Carolina, emoldurando sua imagem gradativamente para o leitor. Já no primeiro parágrafo da primeira 
parte, o jornalista evoca o caráter de veracidade do seu discurso e anuncia o texto como a história real, que será contada por ele, de Carolina Maria de Jesus: "tenho que contar uma história, conto. Bem contada, no exato acontecido, sem inventar nada" (Dantas, 1960, s/n).

De dentro do barraco, dividida a humanidade entre pessoas e cadernos, passa à favela, cenário descrito como "a miséria mais miserável do mundo nosso". Para que a favela torne-se signo concreto e presente aos olhos do leitor o prefaciador se coloca como testemunha, apta a descrever o espaço e o cotidiano dos moradores.

\begin{abstract}
A gente passa na Rua A, pode até ver Carolina na janela, que não presta atenção nêle. Desvia da poça dágua, olha para o bôlo de meninos nus, ouve um palavrão no escuro de dentro de um barraco qualquer, depois passa um, dois, três, dez barracos. No fim da rua, a gente já viu algumas dezenas de infelicidades e tem vontade de fechar os olhos e tapar os ouvidos. De covarde, que não tem só a Rua A na favela do Canindé. Tem a Rua B e a Rua C e a Rua do Pôrto, esta na beiradinha do Tietê, uma lama só (Dantas, 1960, s/n).
\end{abstract}

Apreende-se do discurso do prefácio que a experiência da miséria cala e, paradoxalmente, só pode ser contada por aqueles que a entendem: os que estão sujeitados e degradados por ela. "A gente", locução reiterada constantemente no prefácio, situa o lócus de inscrição - e de leitura - no ponto de vista do grupo prestigiado que poderia, caso compreendesse seu sentido social, suplantar a favela, a miséria, os favelados.

\begin{abstract}
Uma miséria tão grande que a gente nem entende ela. Ou não quer entender verdade verdadeira. Se a gente entendesse, a favela não estava plantada lá na beira do Tietê. Já que está, o melhor é a gente fechar os olhos e tampar os ouvidos. Convém. São eles que entendem - os que moram lá e se degradam lá, na fome, no lixo, na cama. Tem menino barrigudo que entende mais que a gente. Tem. Até cachorro magro entende mais. Só que eles não dizem nada. Êles choram, gritam, brigam, amam, amor de muitos jeitos, dizem palavrões, suicidam-se, apertam o estômago, mas não dizem nada (Dantas, 1960, s/n. Ênfase minha).
\end{abstract}

Posto que "eles não dizem nada", é justamente da impossibilidade do subalterno falar ${ }^{20}$ que surge Carolina: "Carolina Maria de Jesus (...) é quem diz e escreve, tinta forte, letra torta, direitinho, tudo da favela. No exato compreendido da miséria vista e sentida. Carolina, irmã nossa, colega minha, repórter, faz registro do visto e do sentido" (Dantas, 1960, s/n).

Assim aparece Carolina Maria de Jesus, como uma exceção ao silêncio de todos os outros, apta, portanto, a representá-los. Seu diário passa a funcionar como representação da

\footnotetext{
${ }^{20}$ A impossibilidade do subalterno falar remete diretamente às reflexões de Gayatri Chakravorty Spivak, que discute as implicações da representação do sujeito do denominado Terceiro Mundo na conjuntura do discurso ocidental em sua obra seminal Can the Subaltern Speak? (1988), cujo referencial primeiro é a sociedade indiana da qual ela advém.
} 
coletividade favelada: "Como ninguém dizia nada, ela resolveu dizer. E foi só achar um caderno com fôlhas em branco e começar a contar" (Dantas, 1960, s/n).

O movimento seguinte é atribuir à voz de Carolina o valor de protesto: "Transformouse em voz de protesto. E há muitos anos grita, bem alto, em seus cadernos, gritos de todos os dias. Os seus gritos e os gritos dos outros, em diário" (Dantas, 1960, s/n). Com efeito, na perspectiva do editor e prefaciador do livro, é a partir de seu caráter de protesto que os leitores devem ler Quarto de despejo: "O livro é o que eu digo e o que todos dirão, agora: grito de protesto. Documento grande de angústia. Saiu do lixo, como sua autora, para revelar pedaço da vida brasileira. Com muita fôrça de forte que é" (Dantas, 1960, s/n).

As próximas três páginas do prefácio ocupam-se com o que contém no diário, transcrevendo passagens relacionadas à miserabilidade dos moradores do Canindé. Em uma dessas passagens Dantas parafraseia um dos episódios de violência narrados por Carolina, é quando observamos outra característica inerente à intenção retórica do texto, atribuir ao diário o valor de guardião da memória coletiva dos pobres:

E numa noite de álcool no barraco que fica perto do rio? Ninguém aqui fora sabe, mas um homem e uma mulher brigaram lá. Tinha uma criança, coitadinha dormindo, e eles (sem querer) caíram em cima dela e machucaram ela. Foi ambulância apitando sereia, levou ela para o Hospital, mas não deram jeito. Os ossos não ligaram mais uns nos outros e a criança morreu. Nenhum jornal disse, ninguém falou mais do menino, que Deus tenha êle num canto do céu que seja bem bonito. Só o diário de nossa irmã Carolina é quem se lembra. Está marcado, lá num caderno achado no lixo, o drama grande do menino pequeno (Dantas, 1960, s/n).

Na segunda parte do prefácio conta-se como ocorreu o encontro entre Carolina Maria de Jesus e Audálio Dantas, quando ele foi apresentado aos cadernos, e a promessa que fez de publicá-los. A terceira explica os procedimentos de edição, organização, seleção e alterações dos manuscritos da autora entregues a Dantas que resultaram na versão publicada. A quarta e última parte da apresentação é intitulada "RECADO (Para Carolina e os outros da favela)". Transcrevo-a abaixo na íntegra:

A reportagem terminou. Eu digo: de tôdas as que eu fiz, em dez anos de correr mundo-Brasil, esta é a mais importante. Não sei, não vi, mas acho que pedaço de minha alma escorreu pelos meus dedos e ficou no papel. Acredito, sem afirmar afirmado. Agora, eu quero falar com Carolina. Todos podem ouvir. Carolina, você gritou tão alto que o grito terminou ferindo ouvidos. A porta do Quarto de Despejo está aberta. Por ela sai um pouco da angústia favelada. É a primeira porta que se abre. Foi preciso abrí-la por dentro e você encontrou a chave. Agora, vamos esperar que os de cá de fora olhem para dentro e vejam melhor o Quarto de Despejo. Sabe, Carolina, eu já vi gente aqui da sala de visitas que anda torcendo o nariz sem nem ao menos sentir o cheiro-fedor do Quarto de Despejo. As narinas dêles não estão acostumadas. Você os desculpa, não é? Em nome de todos os que estão no Quarto de Despejo, cuja miséria revelada poderá operar o milagre e haja humildade 
necessária para a compreensão. Êles precisam bem precisado de olfatos mais humildes. Os do Quarto de Despejo, nem todos, também torcem o nariz. Mas êsses não tem culpa culpada; apenas acham que o cheiro-fedor deve ficar lá dentro, no escuro escondido. Êles não entendem a razão de você querer, com tanta vontade abrir a porta. Os de lá-de-dentro, Carolina, muitos dêles, têm até malquerência com você. Mas isso é de miséria grande, o desentendimento. A êles eu falo: grande é a irmã que abriu a porta. Ela é um pouco de vocês todos, na revelação. É até um pouco-muito do Brasil, que muitos são os quarto de despejo, sul-norte-leste-oeste, beira de rio, beira de mar, morro e planalto. Vejam o sol que entra agora no Quarto de Despejo. Aqueçam-se, irmãos, que a porta está aberta. Carolina Maria de Jesus achou a chave. Aqueçam-se! (Dantas, 1960, s/n).

Desse "recado" que Audálio Dantas direcionou a autora e aos demais favelados muitos elementos relevantes se destacam. A voz em primeira pessoa se posiciona no lugar de mediador entre os que estão "cá fora" e a massa homogênea de favelados - "os de lá-dedentro", diante da autora, antecipando a recepção de ambos os grupos. Para os leitores de fora, Carolina funcionará como agente de uma transformação extraordinária: "Você os desculpa, não é? Em nome de todos os que estão no Quarto de Despejo, cuja miséria revelada poderá operar o milagre e haja humildade necessária para a compreensão". Delineada está sua utopia: a publicação de Quarto de despejo poderá trazer a redenção para a elite branca, salvando-a de sua própria incompreensão. Os favelados, por outro lado, "não tem culpa de nada", "não entendem a razão de você querer, com tanta vontade abrir a porta", estão aquém da subjetividade humana, presos ao "desentendimento" fruto da "miséria grande". Os grupos sociais são polarizados em duas instâncias dicotômicas, formam identidades fechadas e contrárias, entre elas, e agindo para que haja uma relação: Carolina.

O repórter reitera os valores atribuídos ao livro disseminados durante o correr de seu texto de apresentação: a escrita de Carolina é um grito de angústia que inventa a chave que irá abrir a porta do quarto de despejo para que entre a luz que aquecerá os que lá vegetam, fazendo com que finalmente existam. Podemos depreender da análise de Dantas que a figura de Carolina Maria de Jesus é posicionada no lugar de alegoria nacional - sua voz, portanto, passaria a representar a enunciação coletiva da massa favelada brasileira. Desse modo, o prefaciador/editor legitima o texto por sua função política e social de denúncia de um estado premente de coisas e, na mesma ação, cria a personagem Carolina Maria de Jesus - a voz da favela.

O prefácio de Quarto de despejo instaura, nesse sentido, um dispositivo de leitura que compreende o livro exclusivamente pela ótica do documento porta-voz. A partir deste dispositivo antecipa-se um lugar fixo para a leitura de Carolina Maria de Jesus como a 
"escritora favelada", cuja construção textual é deixada de lado, trazendo implicações em sua trajetória como escritora. Para Regina Dalcastagnè, tal dispositivo funcionaria como um alerta para os leitores: "não se preocupem, não estamos querendo dizer que isto seja literatura":

Vista de dentro da favela, Carolina Maria de Jesus ascende como escritora; vista do lado de fora, ela permanece como uma voz subalterna, como a favelada que escreveu um diário. Portanto, ao lado da discussão sobre o lugar da fala seria preciso incluir o problema do lugar de onde se ouve. Afinal, é daí que a literatura recebe sua valoração (Dalcastagnè, 2005, p. 72).

A partir da observação atenta de alguns aspectos da edição podemos examinar a construção da figura que passou a ser a "escritora favelada". Os procedimentos adotados na edição do diário Quarto de despejo são descritos na apresentação "Nossa irmã Carolina" nos seguintes termos:

Os originais que contêm o diário agora publicado estão em vinte cadernos, quase
todos encontrados no lixo. Lendo-os, quando o tempo sobrava um pouco, demorei
uns dois meses. Depois, selecionei trechos, sem alterar uma palavra, para compôr o
livro. Explico: Carolina conta o seu dia inteiro, com todos os incidentes, fiel até ao
ato de mexer o feijão na panela. A repetição seria inútil. Daí, a necessidade de
cortar, selecionar as histórias mais interessantes. A fome aparece com frequência
espantosa. Mas disto não tenho culpa. Nem Carolina. Nem os favelados da favela do
Canindé, seus personagens.
Como esta história que conto e garanto é o exato acontecido, tenho de acrescentar
que, em alguns poucos trechos, botei uma ou outra vírgula, para evitar
interpretação dúbia de frases. Algumas cedilhas desapareceram, por desnecessárias,
e o verbo haver, que Carolina entende apenas como um a assim soltinho,
confundindo facilmente com o artigo, ganhou um h de presente. Se não podia haver
confusão. E confusão, de briga, há muita no Quarto de Despejo. De meu, no livro, há
ainda uns pontinhos que aparecem assim (...) e indicam supressão de frases.
Quando os pontinhos estão sozinhos, sem ( ), nos parágrafos, querem dizer que foi
suprimido um trecho ou mais de um trecho da narrativa original. Há também a dizer
que há muitos dias sem registro, ou porque Carolina deixou de escrever ou que
foram suprimidos na passagem para o livro. De julho de 1955 a maio de 1958 , ela
deixou de escrever o diário. Não sei qual a razão. Desesperança, talvez (Dantas,
1960, s/n).

Porém, em detrimento do que se afirma no prefácio, na edição do livro os manuscritos de Carolina passaram por diversas transformações, incluindo supressões, acréscimos e substituições de termos, expressões e trechos inteiros, que suplantam a simples intenção de viabilizar a coerência textual que o editor explica no texto de apresentação. Estas transformações, em suma, ajudaram a moldar a imagem da "escritora favelada", cujo discurso deveria estar circunscrito exclusivamente à subalternidade: as supressões ocorridas na edição do texto de Carolina Maria de Jesus corroboraram uma imagem de autora cujos conhecimentos deveriam estar ligados intrinsecamente, e somente, ao contexto social da favela, não podendo, por exemplo, revelar traços de formação humanística ou de 
pensamento reflexivo. O arranjo da imagem da narradora em um enquadramento colado à imagem da condição de mulher de baixa escolaridade, alguém comum do povo, cujo discurso deveria ser verossímil como algo legítimo vindo da favela, acaba por subtrair a dimensão intelectual que Carolina possuía e exercitava em sua escrita.

No trecho abaixo observamos um exemplo deste arranjo, onde se lê em negrito a versão manuscrita de Carolina, publicada na tese de Perpétua (Perpétua, 2000) e em itálico a versão que foi publicada na entrada do dia 3 de junho de 1958 (Jesus, 1960, p. 51):

Quando eu começei a escrever ouvi vozes alteradas. Faz tanto tempo que não ha briga na favela. [Uns 15 dias pensei até que os favelados estavam lendo Socrates. 0 homem que não gostava de polemica. Ele dizia: que pode se realisar uma Assembleia e ressolver os problemas com palavras.]

Era a Odete e o seu espôso que estão separadós. Brigavam porque ele trouxe outra mulher no carro que êle trabalha (Citado por: Perpétua, 2000, p. 182).

O excerto em negrito foi inteiramente suprimido no texto publicado, negando uma face cara à Carolina: a reflexão acerca do valor da palavra e a sua importância na resolução de conflitos. Outro exemplo de interferência observa-se no registro de 5 de julho de 1959:

Ouvi [o rádio divulgando] no radio o desastre da central De manhã o José Carlos disse que [tem] tinha vontade de ver um encontro de trens. Eu disse-Ihe: Não penses nisto. [pobre operário] Coitados dos operários! (Perpétua, 2000, p. 176).

Na substituição 1, observa-se alteração do registro linguístico de Carolina por uma expressão mais próxima da coloquialidade; na substituição 2, troca-se a conjugação do presente para o pretérito imperfeito, modificando o tempo do presente narrativo no discurso indireto, fazendo com que a vontade do menino adquira um tom de continuidade, e não de pontualidade, como fora originalmente escrita; na substituição 3, a modificação do singular para o plural pode indicar a potencialização de uma consciência individual para uma consciência de classe.

Diversos exemplos de substituições de elementos da linguagem de Carolina em direção a expressões mais populares são observados nestes trechos, onde se lê destacado em negrito o que foi subtraído e em itálico a versão que aparece publicada:

11 de junho de 1958. O José Carlos esta mais calmo depôis que [expeliu] botou os vermes, 21 vermes. [Notei-lhe grandes diferenças nos modos. As vêzes uma criança é inrriquieta por uma causa fisica. Ele não comia. Hoje jantou. e fói dêitar-se. Esta mais sensato. Disse-me que quer aprender dividir. Uma senhora disse-me para eu dar-lhe lavagem, ferver o alho, e hortelã. Que ela trabalha com médico. - As sénhora trabalha com médico em quê? - Eu sóu lavadeira de um hospital. pensei: que prepoténcia. Pór ser lavadeira de um hóspital já acha que pode indicar remédios Ah! Cada um nêste Brasil!] (Versão publicada: Jesus, 1960, p. 59; Versão suprimida: Citado por: Perpétua, 2000, p. 180). 
15 de junho de 1958. Recordei imediatamente da Lêila porque eu [havia] tinha dito so para ela. (Versão publicada: Jesus, 1960, p. 64; Versão suprimida: citado por: Perpétua, 2000, p. 176).

4 de julho de 1958. O que dêixou-me preocupada foi o predio ter 82 andar. Ainda não li que [em] São Paulo [existe] tem predio tão elevado assim. (Versão publicada: Jesus, 1960, p. 80; Versão suprimida: citado por: Perpétua, 2000, p. 176).

8 de julho de 1958. As mulheres estavam comentando que os [notivagós] homens beberam 14 litros de pinga. (Versão publicada: Jesus, 1960, p. 85; Versão suprimida: citado por: Perpétua, 2000, p. 177).

11 de julho de 1958. Ao redór da tórneira amanheçe chêio de [excrementos] bosta. (Versão publicada: Jesus, 1960, p. 90; Versão suprimida: citado por: Perpétua, 2000, p. 177).

20 de junho de 1958. Ele não conheçe a Vera. E nem a Vera [Ihe] conheçe ele. (Versão publicada: Jesus, 1960, p. 66; Versão suprimida: citado por: Perpétua, 2000, p. 177).

21 de junho de 1958. Vesti o José Carlos para ir [a] na escola. (Versão publicada: Jesus, 1960, p. 66; Versão suprimida: citado por: Perpétua, 2000, p. 177).

Em muitos momentos as alterações, sejam supressões sejam substituições, modificam imensamente o sentido do texto, como neste exemplo, em que Carolina conversa com dois meninos que haviam fugido do Juizado de Menores:

Falavam que residem na Vila Maria. Que tem mãe. Aconsêlharam [os] meus filhos para ser bons para mim. Que os filhos estão melhor com as mães. Que a coisa melhor do mundo, é [uma] mãe. [Com estas palavras,] êles [pagaram] pegaram as roupas que eu dêi-Ihes. (Versão publicada: Jesus, 1960, p. 87; Versão suprimida: citado por: Perpétua, 2000, p. 178).

Nesta outra passagem, a substituição modifica a expressão metafórica por outra, de caráter apenas denotativo: "9 de junho de 1958. Quando existia a saudósa Rua Itaboca, eu digo saudósa porque vêjo tantos homens comentando a extinção da Zona [com suas mariposas do amôr] do meretrício" (Versão publicada: Jesus, 1960, p. 98; Versão suprimida: citado por: Perpétua, 2000, p. 180).

Nesta passagem, de 25 de julho de 1958, observamos que as supressões que o texto original sofreu na edição resultam no comprometimento da própria sequencia lógica da narrativa, extirpando do texto a relação de causa e consequência entre a alegria que Carolina sentia e a observação que estava fazendo do espaço enquanto caminhava pelas ruas. A descrição subjetiva da beleza da paisagem e do dia, em consonância direta com as sensações da narradora, é apagada, retirando da narrativa seu alcance poético:

[Dêixei o lêito as 5 e mêia. Não fiz café. Fui carregar agua. Dei pão com banana para os meninos saí de casa, as 7 hóras. Não estava nervosa. Não tinha versos no cerebro. 
Estava tranquila. Fitei o espaço com sua côr azulada e as nuvens girando, em direção ao póente. $O$ sol com seus reflexos côr de ouro estava calido. $E$ eu, começei transpirar. Dei graças a Deus, quando a brisa surgiu para arrefecer um pôuco.

Fitava as avês que deslizavam no espaço como se fossem impelida pela viração.]

Achei o dia bonito e alegre. Fui catando papel (Versão publicada: Jesus, 1960, p. 99; Versão suprimida: Perpétua, 2000, p. 179).

Em outro trecho, a referência à Sócrates novamente é apagada:

E a Odete vendo o seu esposo sair com outra no carro, ficou furiosa. Vieram chingarme de intrometida. Eu penso que a violência não ressolve nada [Socrates adotava Assembléia de palavras para ressolver uma questã. Mas] Assembleia dos faveladós é com paus faca [porrêtes] pedradas e violências. [Depois do crime vem o arrependimento. E o assassino acha que têve razão de matar] (Citado por: Perpétua, 2000, p. 183).

As interferências ocorridas no processo de edição do texto de Quarto de despejo são responsáveis por traçar um perfil estereotipado para Carolina, que estava de acordo com o perfil estereotipado da própria favela. Dentro desse estereótipo, as demonstrações de conhecimento são apagadas em nome do caráter denunciativo e descritivo do texto publicado, como se a capacidade de reflexão estivesse condicionada a pressupostos de classe.

O preciosismo linguístico de Carolina Maria de Jesus é revelador de algo que o editor desconsiderou: o fato de que pela e na linguagem, em seu uso e tangência, a autora buscava distanciar-se da favela - sair da instância de subalternidade. Não obstante, o editor, ao forçar o tom coloquial ao texto acabou por circunscrevê-la ao espaço que a escritora quis romper.

Momentos de fabulação, em que a narrativa é tecida em linhas mais subjetivas, momentos de construção poética, de imagens metafóricas e momentos de reflexão, são extirpados da narrativa a fim de valorizar apenas a objetividade da denúncia, do testemunho imediato das condições sociais precárias. Em consequência disto, as passagens em que Carolina Maria de Jesus demonstra a potencialidade de sua reflexão intelectual e humanística, sua capacidade de interpretação sobre o papel da palavra em detrimento da violência que regia grande parte das relações em sua comunidade - conforme os excertos que citamos em que a narradora traz a referência de Sócrates - concorrem com a imagem verossímil da escritora catadora de lixo. "Privilegiar a ação em detrimento da reflexão, assim como privilegiar a narração em detrimento da descrição é um dos pontos mais marcantes na caracterização do texto que o editor vai dar a conhecer ao público" (Perpétua, 2000, p. 183).

As condições de pobreza são também potencializadas, aumentando, no texto, o estado de miserabilidade da autora: 
Cheguei na rua Frei Antonio Santana Galvão 17 trabalhar para a Dona Julita. [Ela deu-me café, batatas doçe abacate e comida.]

Achei um cará no lixo, uma batata doçe e uma batata salsa. Cheguei na favela os meus meninos estavam roendo um pedaço de pão duro. pensei: para comêr êstes paes, era preciso que êles tivessem dentes eletricos.

Não tinha gordura. Puis a carne no fogo com uns tomates que eu catei na Fabrica pêixe puis o cará a batata [salsa] e agua. Assim que ferveu eu puis o macarrão que os meninos cataram no lixo. Os favelados aos poucos estão convençendo-se que para viver precisam imitar os côrvos. Eu não vêjo eficiência do serviço social em relação ao favelado. [Em vez de serviço social devia intitular-se serviço abstrato.] Amanhã não vou ter pão. Vou cosinhar [as batatas] a batata docê [que a Dona Julita deu-me] (Versão publicada: Jesus, 1960, p. 41; Versão suprimida: Perpétua, 2000, p. 186).

A simples alteração de "as batatas" para "a batata" reduz a expectativa de saciar a fome cotidiana, sempre narrada no diário, e a omissão do ato de generosidade de Dona Julita, personagem constante na narrativa, aumenta a ideia de que Carolina estava por si, lutando sozinha contra as agruras da vida sem receber ajuda externa. Desenha-se o perfil de uma vítima social, sem capacidade de julgamento, passiva e submissa, objeto da pobreza, e não sujeito do seu percurso.

Ademais, a consideração da escritora somente enquanto "porta-voz" é incoerente com sua própria escrita, porquanto sua individualidade seja pontuada e reiterada de modo constante nas anotações que compõe sua narrativa. São abundantes as passagens de Quarto de despejo que registram a ausência de traços identitários cultivados havidos entre a autora e os moradores da favela, com os quais Carolina compartilhava apenas a mesma condição material precária:

17/07/1955 Domingo. [...] A D. Aparecida perguntou-me: A senhora está grávida? Não senhora, respondi gentilmente. E lhe chinguei interiormente. Se estou grávida, não é da sua conta. Tenho pavor destas mulheres da favela. Tudo quer saber! A língua delas é como os pés de galinha. tudo espalha. Saí à noite, e fui catar papel. Quando eu passava perto do campo do São Paulo, várias pessoas saiam do campo. Todas brancas, só um preto, e o preto começou a insultar-me (Jesus, 1960, p. 15).

A escrita é um dos principais fatores que tornam Carolina isolada do grupo:

O Seu João veio buscar as fôlhas de batatas. Eu disse-lhe:

- se eu pudesse mudar desta favela! Tenho a impressão que estou no inferno.

... Sentei ao sol para escrever. A filha da Silvia, uma menina de seis anos, passava e dizia:

- está escrevendo, negra fidida!

A mãe ouvia e não repreendia. São as mães que instigam (Jesus, 1960, p. 28).

14 de julho. Passei o dia deitada por estar com febre e dor nas pernas. Não tinha dinheiro, mas eu havia deixado uns ferros lá no senhor Manoel e mandei o José Carlos ir pesar e receber. Ganhou 22 cruzeiros. Comprei 5 de pão e 5 de açúcar e comprimido. Levantei só para preparar as refeições. Passei o dia deitada. O José Carlos ouviu a Florenciana dizer que eu pareço louca. Que escrevo e não ganho nada (Jesus, 1960, p. 92). 
Momentos de solidariedade existem, mas são menos frequentes que os de intriga e desentendimento com os outros moradores, seus vizinhos da favela.

21 de agosto... Fiz café e mandei os filhos lavar-se para ir na escola. Depois saí e fui catar papel. Passei no Frigorífico e a Vera foi pedir salsicha. Ganhei só 55 cruzeiros. Depois voltei e fiquei pensando na minha vida. O Brasil é predominado pelos brancos. Em muitas coisas êles precisam dos pretos e os pretos precisam dêles. (...) Quando eu estava preparando para fazer o jantar ouvi a voz da Juana que pediu-me alho. Dei-lhe 5 cabeças. Depois fui fazer o jantar e não tinha sal. Ela deu-me um pouco (Jesus, 1960, p. 113).

Há no diário diversas passagens metanarrativas que descrevem o processo de sua própria elaboração e o reflexo da escritura na vida cotidiana da autora: "Hoje o dia me foi benéfico. As rascoas da favela estão vendo eu escrever e sabe que é contra elas. Resolveram me deixar em paz" (Jesus, 1960, p. 22).

A reflexão acerca dos elementos apontados até aqui sugere que a edição do Quarto de Despejo já antecipa a recepção do texto de Carolina Maria de Jesus, privilegiando aspectos específicos de modo a elevar o texto diarístico ao patamar de narrativa de porta-voz das minorias. No entanto, o próprio contexto histórico do momento de estreia abarcava uma conjuntura cultural, social e política que possibilitaram a visão da autora do ponto de vista da representação coletiva. 


\section{A EXPERIÊNCIA DA ESCRITA E A ESCRITA DA EXPERIÊNCIA}

\section{1 - Uma mulher negra (e pobre) levanta a opinião pública}

Será que a sorte do póeta negro é negra igual a sua pele?

- Carolina Maria de Jesus

O sucesso notável de público do primeiro livro de Carolina Maria de Jesus parece indicar que sua voz fora bastante audível aos ouvidos dos leitores nos anos 60. Com efeito, a popularidade do diário pode ser pensada em termos históricos. Levine e Meihy observam que, no Brasil, o começo da década de 1960 trazia uma onda reformista "caracterizada pelo prenúncio de que as camadas pobres poderiam produzir figuras - no caso uma mulher negra - que levantariam a opinião pública" (Levine \& Meihy, 1994, p. 32).

Contudo, se a emergência do discurso de figuras como Carolina Maria de Jesus neste momento histórico caracteriza "uma onda reformista", é ilusório afirmar que esta discursividade tenha aí os seus inícios. O Brasil, como se sabe desde pelo menos que Machado de Assis compôs o episódio da "tabuleta do Custódio" ${ }^{21}$, desfez os laços coloniais com Portugal sem que isso representasse qualquer mudança em sua ordem social e econômica. A elite que determinou o movimento de independência encontrara no liberalismo europeu uma fórmula para adentrar no comércio internacional sem o jugo de Portugal. As ideologias europeias "adaptadas" por essa elite "não descrevem sequer falsamente a realidade" (Schwarz, 2000, p. 18), pois, aos quatro princípios básicos do Liberalismo econômico - quais sejam: defesa da propriedade privada; liberdade econômica (livre mercado); participação mínima do Estado nos assuntos econômicos da nação e igualdade perante a lei (estado de direito) - o Brasil respondia com o regime de trabalho escravo. As ideias estavam fora de lugar e perfeitamente acomodadas aos interesses da elite, bastando para isto notar que a abolição da escravidão deu-se apenas em 1888, apesar da Constituição

\footnotetext{
${ }^{21}$ Refiro-me ao Romance Esaú e Jacó, onde o doceiro Custódio, dono da "Confeitaria do Império" manda trocar a tabuleta de sua loja que "Estava rachada e comida de bichos. Pois cá de baixo não se via" numa alusão direta ao regime imperial que ruiu sem a participação popular. Às vésperas da inauguração da nova tabuleta Custódio ouve rumores da revolução e "vagamente da república", manda um bilhete ao pintor da tabuleta com o seguinte recado: "Pare no d.", pois não sabia se mandava pintar a palavra Império ou República.
} 
Política do Império, de 1824, já trazer em seu texto partes da Declaração dos Direitos do Homem e do Cidadão (1789).

De acordo com Antonio Candido (2006) a literatura entrou no nosso país como uma imposição, como um braço do corpo de ações empreendido pelos colonizadores para fortalecer aqui seu domínio econômico, político e cultural. Para a compreensão do sistema literário proposto por Candido, um conceito relevante é o de empenho da literatura na construção da Nação, visto que construir uma literatura independente da portuguesa articulava-se diretamente ao projeto de construção da Nação brasileira. A ideia de "empenho", não obstante, não se refere a um fazer literário que "seja social ou deseje tomar partido ideologicamente". Com o conceito o crítico está apontando para o fato de que a literatura é "toda voltada, no intuito dos escritores ou na opinião dos críticos, para a construção duma cultura válida no país. Quem escreve, contribui e se inscreve num processo histórico de elaboração nacional" (Candido, 2006, p. 20) ${ }^{22}$.

A cultura válida para o país negava a participação dos universos de significação dos negros e indígenas, embora estes avultassem em personagens estereotipados nas letras dos escritores canônicos, que os constituía como os Outros da nação, embora com diferenças significativas em relação à representação dos negros e dos indígenas. Apenas a título de exemplo, tomemos José de Alencar, que no romântico século XIX formulou nossa identidade nacional como uma síntese entre o branco-europeu e o indígena nativo. Entretanto, aquele nascido dessa mistura, que passará a ser o legitimo brasileiro, não é exatamente um mameluco, mas sim um branco-não-europeu. Os dois casos emblemáticos são O Guarani e Iracema, ambos romances fundadores, em que o/a índio/a (Peri e Iracema) é idealizado/a e inscrito/a no texto como se fosse parte de uma etnia primordial e longínqua, o nosso "bom selvagem" de coração puro. O filho da relação entre o índio e o branco - o brasileiro - será criado na cultura e na racionalidade europeia. Em contrapartida, Alencar escreveu uma peça de teatro que foi encenada e tornou-se um sucesso de público em 1857: "Demônio familiar" apresenta o negro como alguém sem escrúpulos que precisava ser tutelado. O sujeito negro

\footnotetext{
22 Para Lilian Schwarcz, entender a Nação segundo um crivo racial permitia certa naturalização das diferenças, já que se passava a explicar hierarquias sociais arraigadas em função de determinações de cunho biológico e natural. Assim, em um contexto de descoberta da nação brasileira, o índio, o africano e o mestiço eram incorporados como obstáculos e barreiras à identidade nacional (Schwarcz, 2000).
} 
produtor de discursos expõe a fragilidade desse esquema, que para persistir precisa ser continuamente reiterado.

Para Lilian Schwarcz, entender a Nação segundo um crivo racial permitia certa naturalização das diferenças, já que se passava a explicar hierarquias sociais arraigadas em função de determinações de cunho biológico e natural. Assim, em um contexto de descoberta da nação brasileira, o índio, o africano e o mestiço eram incorporados como obstáculos e barreiras à identidade nacional (Schwarcz, 2000). Entretanto, apesar de distanciados da esfera "legítima" de elaboração dos discursos engajados com a formação da Nação, a escrita literária de sujeitos negros existe desde há muito.

Em termos históricos, muitas mulheres negras já "levantaram a opinião pública" por aqui. A inscrição literária afrofeminina no Brasil materializa-se desde o século XVIII, com a escrita de Rosa Maria Egipcíaca da Vera Cruz (1719 - 1778), autora do mais antigo livro escrito por uma mulher negra em terras nacionais ${ }^{23}$. Em Sagrada Teologia do Amor Divino das Almas Peregrinas, um livro de mais de duzentas páginas, ela registra suas visões e experiências místicas. A biografia de Luiz Mott (Mott, 1993) revela o caráter imensamente transgressor da negra Rosa que adentrou espaços até então restritos apenas aos senhores: a palavra escrita e acesso direto aos desígnios divinos, o que lhe dera a autoridade de ter sido considerada, durante a vida, uma santa:

Foi reputada como portadora de poderes paranormais, amealhando numeroso séquito de devotos não só entre o populacho, mas também nas elites, a ponto de

\footnotetext{
${ }^{23}$ A longa biografia de autoria de Luiz Mott, Rosa Egipcíaca. uma santa africana no Brasil traz, em mais de 700 páginas, referências a inúmeros documentos recolhidos na Torre do Tombo (Portugal) em virtude do processo inquisitório sofrido pela ré Rosa Maria. De acordo com esta extensa pesquisa, sabemos que ela era natural da Costa da Mina, da nação courana. Rosa Maria Egipcíaca desembarcou no Rio de Janeiro aos seis anos de idade, escravizada. Naquela cidade, viveu até os quatorze anos e, depois de ser violentada por seu proprietário, foi vendida para outro senhor residente em Minas Gerais que a obrigava a prostituir-se. Na Vila da Inconfidência foi escrava da mãe de Frei Santa Rita Durão, para quem trabalhava como meretriz, como muitas outras negras de ganho - escravas a serviço dos donos que deveriam praticar atividades lucrativas nas vilas e cidades e dividir com eles seus lucros - até o dia em que "teve o espirito maligno, o qual a molestava muito". A partir daí, começa a ter visões místicas, o que a leva a abandonar a prostituição e a se tornar beata. Um padre exorcista conhecido como "Xota-diabos" comprou sua alforria e a levou para o Rio de Janeiro. Nessa cidade, em 1754 fundou o Recolhimento de Nossa Senhora do Parto, "cuja capela, reconstruída, existe ainda hoje, no centro comercial do Rio" (Mott, 1993, p. 8). De acordo com Mott: A negra courá tem ambições: não basta pregar, como Cristo fazia. Ela se dá conta que se aprender a ler terá a chave dos mistérios divinos, poderá mergulhar na própria fonte da revelação católica e por conta própria aprender orações, ladainhas e dogmas que até então só tinha acesso ex audito, através do ouvido, quer nos sermões dominicais, quer nos conselhos particulares que lhe davam os sacerdotes. Rosa cumprirá a determinação da 'Divina Pombinha': aprenderá a ler e a escrever (Mott, 1993, p. 80).
} 
ser adorada de joelhos por seu ex-senhor e proclamada por diversos sacerdotes como “a nova Redentora do gênero humano" (Mott, 1993, p. 8) 24.

Quase trinta anos antes da data em que a abolição da escravidão negra no Brasil foi decretada, Maria Firmina dos Reis, na província do Maranhão, publicava o primeiro romance brasileiro escrito por uma mulher e também nosso primeiro romance abolicionista: Úrsula, de 1859. Dentre a literatura antiescravista mais conhecida, o romance antecede Castro Alves, cuja produção se estende de 1876 a 1883; é anterior a Manoel de Macedo, autor de Vitimas algozes (1869); e anterior a Bernardo Guimarães, de Escrava Isaura (1875). A autoria do romance é colocada em contraposição à tradição literária, construída sobre obras masculinas, como observamos já no prólogo da obra, onde se afirma que "pouco vale este romance, porque escrito por uma mulher, e mulher brasileira, de educação acanhada e sem o trato e conversação dos homens ilustrados" (Reis, 2004, p. 13). Deste lugar de fala, Maria Firmina ergueu sua voz, e, mesmo sabendo do "indiferentismo glacial de uns" e do "riso mofador de outros", desafiou a todos: "ainda assim o dou a lume".

Embora a inscrição da mulher negra nas letras nacionais seja fato, a literatura brasileira canônica engendrou discursividades em que a feminilidade negra se materializa principalmente sob a égide da dominação, criando categorias de representação estereotipadas que persistem até hoje: ora o corpo objeto ultrassexualizado da mulata - por exemplo: Rita Baiana, clássica personagem de O Cortiço, de Aluísio Azevedo, publicado em 1890; Gabriela de Jorge Amado ou a Negra Fulô de Jorge de Lima. Embora essa última não seja caracterizada através da categoria 'mulata', mantenho-a no mesmo conjunto pelo apelo sexual que ela exerce no senhor branco e que funciona no texto como fator legitimador de sua opressão, transformando o senhor em vítima de sua sensualidade; ora a passividade submissa, generosa e auto-sacrifical da mãe-preta - Tia Anastácia de Monteiro Lobato; ora a bestialização da negra escravizada - Bertoleza, também personagem de O Cortiço.

Imagens de controle de fácil observação ao leitor que se debruçar sobre as obras de escritores como José de Alencar, Aluísio de Azevedo, Gregório de Matos, Monteiro Lobato, Bernardo Guimarães, Jorge Amado, entre outros; que compõe nossa tradição literária. ${ }^{1}$. Tia Anastácia de Monteiro Lobato; Bertoleza, também personagem de O Cortiço.

\footnotetext{
${ }^{24}$ Inspirada na vida da africana, Heloísa Maranhão compõe um romance chamado Rosa Maria Egipcíaca da Vera Cruz: a incrivel trajetória de uma princesa negra entre a prostituição e a santidade. Rio de Janeiro: Rosa dos tempos, 1997.
} 
Quando Carolina Maria de Jesus surgiu no cenário da literatura, pautado pela exclusividade de uma casta - entendendo aqui que a casta letrada brasileira permeia classes e origens, mas se sustenta numa ordem de gênero e raça - sua escrevivência se inseriu em um campo de autorrepresentação cujos passos vinham de longe. Com efeito, embora a academia ainda pouco diga sobre Auta de Souza, poeta potiguar nascida em 1876 cuja primeira publicação em jornais data de 1894, autora do livro de poemas Horto publicado em 1900, com prefácio de Olavo Bilac, que alcançou uma tiragem de mil exemplares, estando atualmente na quinta edição; pouco diga de Antonieta de Barros, também conhecida por Maria da Ilha, que além de professora foi a primeira mulher catarinense a se eleger para uma cadeira da Assembleia Legislativa, tendo fundado e dirigido o jornal A Semana (1922-1927) e Vida Ilhoa (1930), autora de Farrapos de Idéias, publicado em 1937; tão pouco conte de Ruth Guimarães, autora de entre outros, Água Funda, de 1943; ou de Anajá Caetano, que escreveu Negra Efigênia: Paixão de Senhor Branco em 1966, tratando de temas como a escravidão e aspectos da cultura africana; e ainda muitas outras, como Geni Guimaraes, autora de Terceiro Filho, publicado em 1979, Leite de Peito e A Cor da Ternura, de 1988 e 1989, respectivamente, e Maria Izabel Leme, autora de Ovelha Negra; mantendo todas essas autoras negras à margem do cânone literário, inclusive do já estabelecido cânone literário feminino, suas vozes romperam o silêncio.

Mas, ao contrário das escritoras e escritores negros que a antecederam, a obra de Carolina atingiu um grande público nacional e internacional. E justamente pelo fato de ter sido escrita por um sujeito cuja experiência social diferia dos pressupostos históricos da casta letrada brasileira. Entretanto, a ascensão inicialmente bem sucedida da palavra caroliniana se choca com a diferença de recepção observada em outros autores negros contemporâneos seus.

Especificamente em São Paulo, já havia uma tradição constituída de produção e circulação de textos literários através da imprensa negra. Nos anos 1920 e 1930, formada por nomes como Raul Joviano do Amaral, Francisco Lucrécio, Correia Leite, Lino Guedes, Arlindo Veiga dos Santos, entre outros, esta imprensa realinhava os sentidos políticos do termo "negro" e assegurava a comunicação e fortalecimento étnico da comunidade negra paulistana, engendrando uma tradição de lutas que elencava Luis Gama, José do Patrocínio e Cruz e Souza como paradigmas históricos. De fato, o paradigma abolicionista se mostrava 
ainda eficaz enquanto estratégia de reivindicação política, dado que após a Abolição da escravatura e a assunção da República a voz corrente entre os novos escritores, poetas e jornalistas negros era aquela que clamava uma espécie de segunda abolição, posto que as condições sociais relegadas ao segmento negro depois do fim do regime escravocrata permaneciam inalteravelmente iníquas, de modo que o "preconceito de cor", conforme expresso nos textos literários e artigos publicados na imprensa negra, era apontado como principal entrave à "integração do negro" à nova ordem política nacional (Bastide, 1973; Fernandes, 1978; Silva, 1990).

Poetas como Oswaldo de Camargo e Eduardo de Oliveira, por exemplo, ativos na imprensa negra, não permaneceram alheios aos debates sobre a Negritude, neologismo polissêmico originário da língua francesa que qualifica a tomada de consciência do sujeito negro quanto à sua condição histórica, assumindo a identidade cultural negro-africana ou da diáspora negra em recusa à assimilação dos valores impostos pelo branco europeu (neo) colonizador. Foi Aimé Césaire quem utilizou pela primeira vez a palavra, em 1939, em seu poema narrativo Cahier d'un retour au pays natal (Caderno de um retorno ao país natal), publicado em 1944. O Movimento da Negritude nasce em Paris por volta de 1934, com um grupo de intelectuais africanos e caribenhos, na sua maioria estudantes, que, atingidos pelo Renascimento Negro norte-americano, assumem um discurso em defesa dos direitos à igualdade racial e em combate ao neocolonialismo europeu. A palavra poética engajava-se nas lutas por emancipação e irradiava pelo mundo afora. Irradiou em Angola, com Agostinho Neto, tornado presidente de sua nação após a derrocada do governo colonial português. Irradiou no Brasil e potencializou elementos à constituição do protesto negro por aqui.

A presença de uma cultura negra em São Paulo fundamentada na tradição escrita é um dado singular da luta política dos negros, como salienta diversos autores (Bastide, 1972; Fernandes, 1978; Andrews, 1998), com destaque para a publicação de periódicos que sustentou a luta do grupo por cidadania na metrópole, reforçando a solidariedade étnica e estruturando-se como espaço de afirmação identitária ${ }^{25}$.

\footnotetext{
${ }^{25}$ O primeiro periódico da Imprensa negra no Brasil foi O Homem de Cor, fundado em 1833 na tipografia do jornalista negro Francisco Paula Brito, o primeiro editor de Machado de Assis, na capital do Império. Ou seja, apenas 25 anos depois que as atividades de imprensa são inauguradas no país, com a vinda da família real em 1808. A pesquisadora acentua que já há registro de jornais negros localizados em São Paulo no período oitocentista. No pós-abolição, dois jornais circularam: "A Pátria - Orgam dos Homens de Côr" (1889) e "O Progresso - Orgam dos Homens de Côr" (1899). O A Pátria foi criado pelo tipografo abolicionista Inácio Araujo
} 


\section{De maneira particular, a raça é também um tropo organizador da constituição} memorialística bem como da observação cotidiana que Carolina Maria de Jesus tece na escrita, pois, em sua arquitetura discursiva, observamos o eu-enunciador revelando o tempo inteiro o racismo atuando sob o eu-enunciado: "Quando alguém ia me xingar era: - Negrinha! Negrinha" (Jesus, 1986, p. 74), e sob a comunidade de que fazia parte, como mostra esse trecho de Diário de Bitita:

As professoras aceitavam os alunos pretos por imposição. Mas se o negro não passava de ano, as mães iam procurar as professoras e diziam: - A senhora não deixou meu filho entrar no segundo ano porque ele é negro, mas ele já sabe ler e escrever o a-b-c. (...) As professoras não respondiam. Compreendiam que havia mentalidades opostas. (...) Depois exclamavam: - Os abolicionistas, vejam o que fizeram! Essa gente agora pensa que pode falar de igual pra igual. (...) E os doutores de Coimbra insultavam D. Pedro II: - Cão! Ele devia perder a nacionalidade portuguesa, essas terras deveriam permanecer colônia portuguesa. (...) E os negros comentavam: - Graças a Deus agora nós temos negros ilustres, temos um negro que canta nos discos e outro que dá receitas. (...) Eu era pequena e ficava ouvindo os velhos falar e pensava: Oh! se me fosse possível virar doutora... eu ia ser doutora Bitita. (Jesus, 1986, p. 39).

As tensas relações na favela narradas por Carolina Maria de Jesus por vezes permeiam a latência do preconceito racial, materializado em verbalizações agressivas em que ser negro passa a ser uma condição negativa mobilizada dentro de um repertório ofensivo:

Lima. Em suas páginas, o jornal homenageava os grandes abolicionistas e trazia o negro como protagonista da história do Brasil. Na segunda edição do jornal, lê-se o trecho abaixo, em que se problematiza já nesse momento o lugar de pertencimento do negro na cidade e a experiência da diáspora: "Chama-nos paulistas porque tivemos nosso berço na cidade de São Paulo, legendária e heróica pelos brilhantes feitos de seus filhos, porém nós que somente podemos dizer: Aqui nesta parte da América do Sul, tivemos nosso berço, mas onde está nossa Pátria?" (Ver: Pinto, 2006, p. 142). Estes jornais, reivindicando a Abolição de fato, traziam a pauta do protesto negro já no limiar do XIX: "Proclamou-se a República, o governo da igualdade, da fraternidade e quejandas liberdades. No movimento republicano, contavam-se muitos pretos e mulatos (que vêm a dar no mesmo) que prestavam e prestam serviços inolvidáveis ao novo regime. Esperávamos nós, os negros, que, finalmente, ia desaparecer para sempre de nossa pátria o estúpido preconceito e que os brancos, empunhando a bandeira da igualdade e fraternidade, entrassem em franco convívio com os pretos, excluindo apenas os de mau comportamento, o que seria justíssimo. Qual não foi, porém, a nossa decepção ao vermos que o idiota preconceito em vez de diminuir cresce; que os filhos dos pretos, que antigamente eram recebidos nas escolas públicas, são hoje recusados nos grupos escolares; e que os soldados pretos que nos campos de batalha têm dado provas de heroísmo, são postos, oficialmente, abaixo do nível de seus camaradas; que para os salões e reuniões de certa importância, muito de propósito não é convidado um só negro, por maiores que sejam seu merecimento; que os poderes públicos em vez de curar do adiantamento do preto, atira-os à margem, como coisa imprestável?” (OP, n. 1, p. 3). Conforme o estudo de Bastide (1973): "O primeiro jornal da Capital de São Paulo de que tivemos conhecimento é o Menelik, aparecido em 1915, 'orgão mensal, noticioso, literário e crítico dedicado aos homens de cor'. A partir daí podemos dividir a história da imprensa negra em três períodos. O que acompanha ou vem em seguida à guerra de 1914, com a Princesa do Oeste (1915), O Bandeirante (1918), O Alfinete (1918), A Liberdade (1918), Kosmos (1922), O Clarim da Alvorada (1924), A Tribuna Negra (1928), Quilombo (1929), Xauter, etc. O segundo período é o que vai de 1930 a 1937, com O Progresso (1931), Promissão (1932), Cultura, social e esportiva (1934), o Clarim (1935), e sobretudo A Voz da Raça (1936). De 1937 a 1945 é o vazio. É preciso esperar a volta do regime democrático para ver surgir de novo a imprensa de cor, com Alvorada e Senzala" (Bastide, 1973, p. 131, 132, 133). 
Como eu já estava previnida, não assustei quando ouvi a voz do Alexandre discutindo com a mãe do soldado Edison. Eu intervi porque ela está gestante. Eu saí para procurar o Bobo para ele retirar o Alexandre de dentro da casa. Mas o Binidito já havia empurrado o Alexandre para fora. Êle entrou no seu barraco e fechou a porta. Estava tão bebado que não podia parar em pé. Deitamos. Eu estava agitada e nervosa porque queria passar o dia escrevendo. Custei durmir. Eu fiquei cançada de tanto correr para ir chamar a Radio Patrulha. Despertei as 4 horas da manhã com a voz do Alexandre que estava maltratando a sua esposa e chingando o soldado Edison. Dizia: - Aquêle negro sujo me bateu. Mas êle me paga! Eu me vingo! Vendo que o Alexandre não parava de falar, eu fui na Delegacia. O soldado que estava de plantão disse: - Favela é de morte! Disse-me que se o Alexandre continuasse a perturbar pra eu voltar as 6 horas. Voltei para a favela, êle estava na rua insultando. Resolvi fazer café. Abri a janela e joguei um pouco dagua no Alexandre. - Você chamou a Radio Patrulha pra mim. Negra fidida! Mas você me paga! (Jesus, 1960, p. 96).

Somado a isso, a revolta da narradora-personagem, motivada pela condição de assujeitamento imposta ao negro é fortemente presente em Quarto de Despejo:

Eu estava pagando o sapateiro e conversando com um preto que estava lendo um jornal. Ele estava revoltado com um guarda civil que espancou um preto e amarrou numa arvore. O guarda civil é branco. E há certos brancos que transforma preto em bode expiatório. Quem sabe se guarda civil ignora que já foi extinta a escravidão e ainda estamos no regime da chibata? (Jesus, 1960, p. 105-6).

Se olharmos para o momento de chegada de Carolina Maria de Jesus em São Paulo, notaremos que é o mesmo período em que as parcelas do grupo negro organizado sofrem o duro golpe ocorrido em novembro de 1937, quando a ditadura Vargas dilui as associações políticas em geral. Esse dado, em si, já poderia sugerir uma dificuldade de contato políticocultural mais estreito entre a autora e os militantes da causa negra. Nas memórias de José Correia Leite registra-se o encontro de Carolina com uma fração do grupo:

[...] Paralisado o Movimento Negro na cidade, a minha casa passou a ser uma espécie de quartel-general dos assuntos de negro. Qualquer coisa que acontecia no meio negro estourava na Rua Augusta. [...] Um dia [por volta de 1937/38] apareceu em casa um poeta negro, com o nome de Emílio Silva Araújo. Era um poeta baixinho e muito esperto, mas a preocupação da poesia dele era a miscigenação. Ele fazia poesia sobre a mulata. Ele tinha um poema muito bonito chamado "Eufrosina", que ele gostava de declamar. Era um sujeito meio desajustado e gostava de ser chamado de "Garouche", em referência a um personagem dos "Miseráveis" do Victor Hugo.[...] Um dia ele apareceu de braços dados com uma negra. - Está aqui uma poetisa que descobri. Eu encontrei com ela na porta da Igreja da Consolação e trouxe pra cá, para vocês ficarem conhecendo o trabalho dela. - disse o Emílio. E ela abriu um caderninho e mostrou umas poesias. [...] Nós tínhamos sempre uns grandes almoços. Aos domingos, se reuniam o Góis e aquela moçada toda para bater papo, já que não se podia fazer nada. E nós ficamos, naquele dia, ouvindo a declamadora, a poetisa que o Silva Araújo tinha levado. Quando perguntamos o nome dela, ela respondeu que se chamava Carolina de Jesus, a mesma que mais tarde escreveu o Quarto de despejo. Ela já era nossa conhecida desde aquela época. Só que ela não fazia poesia que falasse de negro, ela nem tinha essa consciência, nem mesmo quando fez o Quarto de despejo. Nunca teve consciência de negra. A 
poesia dela, na época, era muito colorida, mas sem nenhuma conotação de origem, de raça (Leite \& Cuti, 1992, p. 138).

O julgamento do militante - diga-se de passagem, com quase duas décadas de militância política sistematizada - segundo o qual Carolina nunca teve "consciência de negra" esbarra no questionamento mais elementar: que tipo de consciência coletiva buscava e defendia o segmento negro organizado àquela altura? Talvez, alguma que já estivesse pronta para o embate travado no solo metropolitano, e evidentemente, diferente daquela manifesta por uma mulher recém-chegada de um universo social rural de estruturas opressoras e que nem ao menos sabia ainda o que significava ser poetisa. Identidades são "inscritas através de experiências culturalmente construídas em relações sociais" (Brah, 2006, p. 371). A estagnação sociocultural ao qual estava imersa a comunidade negra interiorana da qual provinha a autora é, como já dissemos, componente importante na composição de suas memórias reunidas sob o livro Diário de Bitita, e pode ser notada, por exemplo, em um de seus episódios, quando Carolina chega a ser presa e sofre violências físicas na prisão junto com a mãe Maria Carolina (conhecida por todos como Cota) simplesmente por estar lendo um livro: o Dicionário Prosódico de João de Deus, que por conta do volume todos acreditaram ser o livro de São Cipriano, o livro que ensinava feitiçaria. Com efeito, se a "identidade negra" de Carolina não satisfazia os anseios políticos do grupo àquela altura, isso não significa que a autora fosse alheia à sua condição própria de mulher negra. Ao contrário, a construção paulatina da identidade literária empreendida pela autora no conjunto de sua obra passa sempre pelos vetores de raça, gênero e classe.

Não obstante, retornamos à pergunta inicial: quais os sentidos para o fato de que Carolina Maria de Jesus protagonizou o maior sucesso de vendas de um escritor negro no século XX e que o mesmo sucesso não fora nem de longe alcançado por autores cuja "consciência negra" igualmente instaurava questionamentos radicais à organização social nacional? ${ }^{26}$

\footnotetext{
${ }^{26}$ O poema "Protesto" (1958), de Carlos Assumpção, como o próprio título demonstra, ilustra o que estamos chamando de questionamento radical à ordem social levada a cabo pelo sujeito negro: "Mesmo que voltem as costas/ às minhas palavras de fogo/ Não pararei/ Não pararei de gritar/ [...] /Senhores/ Atrás do muro da noite/ Sem que ninguém o perceba/ Muitos de meus ancestrais/ Já mortos há muito tempo/ Reúnem-se em minha casa/ E nos pomos a conversar/ Sobre coisas amargas/Sobre grilhões e correntes/ Que no passado eram visíveis/ Sobre grilhões e correntes/ Que no presente são invisíveis/ [...] /Mas, irmão, fica sabendo/ Piedade não é o que eu quero/ Piedade não me interessa/ Os fracos pedem piedade/ Eu quero coisa melhor/ Eu não quero mais viver/ No porão da sociedade/ Não quero ser marginal/ Quero entrar em toda parte/ [...] / Eu quero o sol
} 
A título de exemplo, destacamos o poeta Solano Trindade (1908-1973) ${ }^{27}$, contemporâneo de Carolina Maria de Jesus. A comparação entre Solano Trindade e Carolina Maria de Jesus nos interessa por agora apenas para problematizar a recepção que ambos angariaram num momento histórico em que a sociedade brasileira vivenciava um rico momento democrático - entre o fim da ditadura do Estado Novo (1937-1945) e o início do regime militar autoritário (1964-1985). Se o fator mais relevante para o sucesso de Quarto de despejo foi o conteúdo dissonante aos anseios da sociedade que se pretendia moderna e desenvolvida, por quais razões a mídia, as editoras e os leitores em geral não reservaram o mesmo espaço para outros escritores que igualmente faziam da palavra escrita uma arma contra a sociedade que os massacrava?

Solano Trindade dialogava com a poesia canônica brasileira e com a literatura negra de língua francesa, inglesa e espanhola, tendo compartilhado a vertente de poesia combativa iniciada com os poetas antilhanos Nicolás Guillén e Aimé Césaire (Bernd, 2011, p. 62). 0 poeta, pernambucano como Bandeira, estava informado das manifestações de ruptura com a representação hegemônica dos negros que ocorriam mundo afora. Novas conceituações acerca do fazer poético brotavam das inquietações de Aimé Cesáire e Leopold Sendhar Senghor e ecoavam na tessitura dos poemas de Solano, cujos elementos se identificam à matéria que emergia da Negritude - um movimento poético articulado principalmente por Aimé Cesárie (Antilhas), Leopold Sédar Senghor (Senegal) e Leon Damas (Guiana Francesa), na França dos anos 30. Em torno da revista L'Etudiant noir (1934-40) construiu-se uma proposta literária nova que rapidamente se internacionalizou. Os poetas negros brasileiros dos anos 60 dialogaram com os novos conceitos que o movimento trazia. Entre as ideias basilares estão: "a reversão do sentido negativo da palavra negro para dela extrair um sentido positivo", a rejeição a toda forma de assimilação cultural ou "imitação" do mundo branco. Hoje outros

que é de todos/ Ou alcanço tudo o que eu quero/ Ou gritarei a noite inteira/ Como gritam os vulcões/ Como gritam os vendavais/ Como grita o mar/ E nem a morte terá força/ Para me fazer calar!" (Carlos Assumpção, excertos de Protesto, 1958).

${ }^{27}$ Solano Trindade foi escritor, ator, pintor, poeta, teatrólogo e incansável pesquisador de tradições populares e negras. É apresentado em coletâneas de literatura afro-brasileira como intelectual de porte "cuja produção reconfigurou a história e a memória dos afro-brasileiros" (Souza, 2004, p. 282). Sua obra: Poemas Negros (1936); Poemas de uma vida simples (1944); Seis tempos de poesia (1958) e Cantares ao meu povo (1961) engendra, em suma, um rompimento com a tradição hegemônica de estereótipos referentes aos negros, representados reiteradamente como submissos e passivos. Em seus textos, Solano desconstrói o desprestígio que o próprio termo "negro" carregava, reivindicando seu pertencimento identitário à sua condição racial que é valorizada, constituindo no tecido poético, bem como na agenda política, o "ser negro" como sujeito histórico combativo. 
sentidos são associados à Negritude: o reconhecimento de uma ancestralidade africana; "a característica de um estilo artístico ou literário"; "o conjunto de valores da civilização africana", entre outros (Bernd, 1987).

Segundo Oswaldo de Camargo ${ }^{28}$, o poema "Tem gente com fome", de autoria de Solano, fora, "Nos meados dos anos 50, alguns anos antes da publicação de Quarto de Despejo, o poema, talvez, mais declamado nas tertúlias que as associações culturais negras realizavam, em São Paulo, lembrando grandes homens e datas especiais" 29.

\author{
TEM GENTE COM FOME \\ Trem sujo da Leopoldina \\ correndo correndo \\ parece dizer \\ tem gente com fome \\ tem gente com fome \\ tem gente com fome \\ Piiiiii \\ Estação de Caxias \\ de novo a dizer \\ de novo a correr \\ tem gente com fome \\ tem gente com fome \\ tem gente com fome \\ Vigário Geral \\ Lucas \\ Cordovil \\ Brás de Pina \\ Penha Circular \\ Estação da Penha \\ Olaria \\ Ramos \\ Bom Sucesso \\ Carlos Chagas \\ Triagem, Mauá \\ trem sujo da Leopoldina \\ correndo correndo \\ parece dizer
}

\footnotetext{
${ }^{28}$ Camargo iniciou suas atividades na ACN (Associação Cultural do Negro), em 1959 publicou o livro de poemas Um homem tenta ser anjo, autoeditado. Em 1961, os 15 Poemas Negros são editados pela Série Cultura Negra, criada pela ACN, com prefácio de Florestan Fernandes. Em 1972, lança o livro de contos O carro do êxito, pela Martins e, depois, a novela A descoberta do frio, pelas Edições Populares, em 1979. A partir do final dos anos 1950, trabalha como jornalista no grupo O Estado de São Paulo, onde se aposentou. Em 1977, convidado por Marcos Faermann, cria, com Hamilton Cardoso e Jamu Minka, a seção Afro-América Latina, do jornal Versus, considerada um dos marcos do ressurgimento do movimento e literatura negros contemporâneos. Nos anos 1980 retoma os trabalhos de poesia e de antologias, com O estranho(1986), A razão da chama (1986) e O negro escrito (1987). Atualmente é consultor do Museu Afro-Brasil.

${ }^{29}$ Conforme se lê no blog do autor. Disponível em: <http://oswaldodecamargo.blogspot.com.br/>. Acesso 12/11/2012.
} 


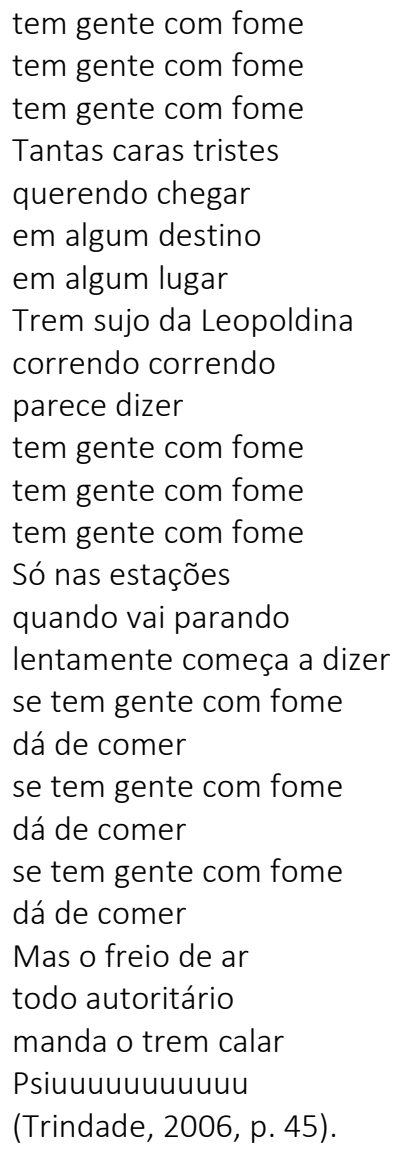

A cadência rítmica do verso, recriando o movimento do trem, vai passando pelos bairros periféricos do Rio de Janeiro, ressaltando a geografia da fome crivada na paisagem suburbana, cujo percurso vai da periferia ao centro do Rio de Janeiro. Ironicamente, do mesmo trem, máquina que parece avisar com seu som que "tem gente com fome", vem o silêncio autoritário do freio ao final, calando o protesto: "Mas o freio de ar/todo autoritário/ manda o trem calar/ Psiuuuuuuuuuuu". O trem sujo da Leopoldina, que teima em dizer "Tem gente com fome", remete a outro, o de ferro, de Manuel Bandeira, que passeia pelos trilhos dos canaviais do Nordeste alardeando: “café com pão/ café com pão/ café com pão" 30.

\footnotetext{
30 "Trem de ferro": Café com pão/ Café com pão/ Café com pão/ Virgem Maria que foi isto maquinista?/ Agora sim/ Café com pão/ Agora sim/ Café com pão/ Voa, fumaça/ Corre, cerca/ Ai seu foguista/ Bota fogo/ Na fornalha/ Que eu preciso/ Muita força/ Muita força/ Muita força/ Oô../ Foge, bicho/ Foge, povo/ Passa ponte/ Passa poste/ Passa pasto/ Passa boi/ Passa boiada/ Passa galho/ De ingazeira/ Debruçada/ Que vontade/ De cantar!/ Oô.../ Quando me prendero/ No canaviá/ Cada pé de cana/ Era um oficia/ Ôo.../ Menina bonita/ Do vestido verde/ Me dá tua boca/ Pra matá minha sede/ Ôo.../ Vou mimbora voou mimbora/ Não gosto daqui/ Nasci no sertão/ Sou de Ouricuri/ Ôo.../ Vou depressa/ Vou correndo/ Vou na toda/ Que só levo/ Pouca gente/ Pouca gente/ Pouca gente...
} 
Em uma construção completamente diversa, a fome, na narrativa caroliniana, antes de estar metaforizada no som do trem que avisa que "tem gente com fome", tem corpo, tem cor, é em primeira pessoa:

Eu amanheci nervosa. Porque eu queria ficar em casa, mas eu não tinha nada para comer... Eu não ia comer porque o pão era pouco. Será que é só eu que levo esta vida? O que posso esperar do futuro? Um leito em Campos do Jordão quando estou com fome quero matar o Janio, quero enforcar o Adhemar e queimar o Juscelino (Jesus, 1960, p. 34).

O cantar altivo de Solano Trindade constitui-se em um terreno de luta simbólica ante a tradição de representação negativa do negro. Isto se nota fortemente, por exemplo, no poema "Sou negro", em que a biografia do sujeito poético é formada pela memória histórica de antepassados que não se conformaram à condição de escravizados.

\section{SOU NEGRO}

\section{Sou Negro}

meus avós foram queimados

pelo sol da África

minh'alma recebeu o batismo dos tambores atabaques, gonguês e agogôs

Contaram-me que meus avós

vieram de Loanda

como mercadoria de baixo preço plantaram cana pro senhor do engenho novo

e fundaram o primeiro Maracatu.

Depois meu avô brigou como um danado nas terras de Zumbi

Era valente como quê

Na capoeira ou na faca

escreveu não leu

o pau comeu

Não foi um pai João

humilde e manso

Mesmo vovó não foi de brincadeira

Na guerra dos Malês

ela se destacou

Na minh'alma ficou

o samba

o batuque

o bamboleio

e o desejo de libertação...

(Trindade, 2006, p.16).

Se, como considerou Meihy, "o aparecimento de Carolina no mundo reconhecido e público dos brancos era uma licença democrática" (Meihy, 1996, p. 9), a obra de Solano Trindade, por outro lado, não poderia jamais ser tomada da mesma forma: como o relato de uma vítima social a preencher a lacuna havida entre aqueles que tinham direito ao discurso no contexto da década de 1960 - como se deu com a recepção de Carolina Maria de Jesus. 
De fato, a elaboração do protesto negro que avulta das rimas do poeta pernambucano agrega um potencial questionador e combativo de outra ordem, quiçá menos interessante à classe leitora que consumiu o texto de Carolina como quem assiste a um espetáculo exótico. "Assim, enquanto investimento, o Diário de uma favelada era sob medida: prometia e facultava o exercício consentido do voyeurismo impune por sobre cenas de pobreza explícita, cenas estas sempre raras na literatura brasileira" (Lajolo, 1996, p. 39). Isso explica o sucesso de vendas que Carolina protagonizou logo no início de sua carreira literária, sucesso perverso, como o desenrolar de sua trajetória pela literatura comprovou.

Além do sucesso incomparável de público frente a outros escritores negros, explicado, do nosso ponto de vista, pelo viés de espetacularização e exotismo com o qual o texto caroliniano fora consumido, outro ponto deve ser considerado, agora em relação à leitura dos próprios pensadores negros. Apesar da notoriedade da primeira obra, para Carolina Maria de Jesus ficou reservado o lugar da mera invisibilidade em duas obras críticas importantes, realizadas por escritores negros, que se debruçam sobre o tema da escritura de sujeitos negros em momentos diferentes do tempo. A primeira de autoria do escritor Oswaldo de Camargo - O negro escrito. Apontamentos sobre a presença do negro na Literatura Brasileira, de 1987 e a segunda do escritor Cuti - Literatura negro-brasileira, de 2010 ${ }^{31}$. Em suma, o nome de Carolina Maria de Jesus aparece pela primeira vez dentro de uma obra que tematiza o negro apenas no ano de 2011, na antologia crítica Literatura e Afrodescendência no Brasil, publicada pela editora da Universidade Federal de Minas Gerais. Esta é a primeira antologia no Brasil a incluir Carolina Maria de Jesus ao rol dos escritores negros representativos da literatura afro-brasileira.

Anos antes da estreia de Quarto de despejo, em 1946, Carolina publicara um primeiro poema no jornal e a mídia Ihe dera a alcunha de "poetisa negra" ${ }^{32}$, todavia, justamente devido à experiência da favela depurada em seu Quarto de despejo, o pertencimento da

\footnotetext{
31 Embora mais restrita, porque delimita o corpus à poesia, a escritora também não aparece nem na primeira (1992) nem na segunda (2011) edição da Antologia de poesia afro-brasileira, de Zilá Bernd.

${ }^{32}$ Audálio Dantas, em depoimento publicado no livro Cinderela Negra: "Ela [Carolina] vinha perseguindo a glória a muito tempo. Não me lembro muito bem quando, mas logo depois do seu sucesso apareceu uma reportagem sobre ela que tinha sido publicada em um jornal - acho que na própria Folha, em 1946 - feita pelo repórter Willy Aureli, dizendo que era uma poetisa negra, e coisa e tal, só que ninguém acreditou. E ele transcrevia trechos do diário dela! Existiu também uma outra, anterior à minha, já nos anos 50. Então, esta busca era antiga. Acho que era um meio dela conseguir, digamos, a sua alforria. Sair daquele estado de miséria" (Meihy \& Levine, 1994, p. 104).
} 
autora ao campo da literatura negra constitui algo polêmico do ponto de vista da crítica elaborada por uma das principais articuladoras dos Cadernos Negros, como tratamos abaixo.

Consideremos primeiro, como um dos polos da questão, a análise de Florestan Fernandes, presente no segundo volume de sua tese magna A Integração do Negro na Sociedade de Classes, publicada em 1964 - concluída logo após e se valendo dos dados coligidos com Roger Bastide para o estudo "Brancos e Negros em São Paulo", de 1958 - em que o sociólogo solicita a obra de Carolina Maria de Jesus como exemplo ilustrativo para corroborar o que ele define como o "lado sombrio da existência do 'negro' na década de 1950". De acordo com este complexo estudo, observa-se que o negro na cidade de São Paulo fora colocado à margem desde os princípios da expansão urbana. No entanto, no período de metropolização da cidade "a expansão da ordem social competitiva adquiriu densidade e intensidade suficientes para se refletir no plano das relações raciais" (Fernandes, 1978, p. 196) e, em detrimento das estratégias de ascensão social levadas a cabo pela população negra, que de resto somavam "impulsões igualitárias de integração social", o desenvolvimento capitalista ainda mantinha imobilizada grande parte dessa população.

\begin{abstract}
As cenas descritas no "diário de uma favelada" sugerem, dramaticamente, que a fome, a miséria, a doença e a desorganização social, com suas variadas consequências sociopáticas, continuam a ter plena vigência para uma vasta parcela da "população de cor". Os porões e os cortiços são substituídos pelas favelas, "o quarto de despejo mais imundo que há no mundo" - "sucursal do Inferno, ou o próprio Inferno". Se a proporção de "negros" sobre a população socialmente desamparada e desorganizada diminui, em compensação aumenta a gravidade dos problemas sociais com que essa parcela da "população de cor" tem de defrontar-se inelutavelmente. "Temos só um jeito de nascer e muitos de morrer". Com essa frase sóbria, Carolina Maria de Jesus leva-nos ao âmago de uma realidade sombria e revoltante (Fernandes, 1978, p. 199).
\end{abstract}

No outro polo, do ponto de vista de José Carlos Sebe Bom Meihy (Meihy \& Levine, 1994), a obra de Carolina pode ser entendida como "literatura negra" principalmente porque representou uma forma de ascensão social diversa daquelas comumente acessadas pelos negros e negras:

A consideração da obra de Carolina como literatura negra interessa como valorização de uma atividade que se diferenciava das demais formas de sucesso social possibilitada aos negros. Se tradicionalmente os pretos sobem na escala social brasileira através da atividade artística - entendo-se como tal quase que exclusivamente o samba, ou do esporte - quase que apenas o futebol -, Carolina significou uma alternativa diferente daquela alcançada por Elizeth Cardoso, Ataulfo Alves, Garrincha ou Pelé. Teria sido através das letras - e das letras diferenciadas do padrão branco - que Carolina Maria de Jesus subira, tornando-se uma escritora e o maior sucesso de vendagem de nossa história no tempo (Meihy, 1994, p. 230). 
Juntando os polos, a obra de Carolina Maria de Jesus - revelando aspectos dramáticos do desamparo social ao qual uma vasta parcela dos negros ainda estava relegada, como mostra Florestan Fernandes - funcionou como motor de ascensão social que retirou a autora da favela e lhe possibilitou melhores condições de vida. De fato, no Brasil poucos são os casos de ascensão social pelas letras, mas, isto seria, como asserta Meihy, o fator mais relevante para qualificar a escritura caroliniana como literatura negra? Com efeito, trata-se de um ponto não pacífico entre a crítica, visto que, justamente o conteúdo trágico de miséria e exclusão que salta das frases fortes de Carolina engendrou uma leitura analítica que a emparedou, como já dito, na situação que descrevia. Tal leitura considerou-a como submissa e conformada ante a realidade que narrou, e, portanto, fora da esfera de construção da identidade negra alinhavada pela literatura. É o caso da leitura de Esmeralda Ribeiro, escritora e coordenadora do grupo Quilombhoje ${ }^{33}$.

Esmeralda Ribeiro, em um artigo intitulado "A narrativa feminina publicada nos Cadernos Negros, sai do quarto de despejo", publicado na coletânea Gênero e representação na literatura brasileira (organizada por Constância Lima Duarte, Eduardo de Assis Duarte e Kátia da Costa Bezerra), traz um ponto interessante para o debate em torno da pertença de Carolina ao campo da literatura negra.

\begin{abstract}
A escritora Carolina Maria de Jesus, em seu diário, Quarto de Despejo constata que diante da vida ela não passa de um ser insignificante, que não tem nenhuma força para mudar o seu destino. É ela quem diz: "... Ontem eu li aquela fábula da rã e a vaca. Tenho a impressão que sou rã. Queria crescer até ficar do tamanho da vaca..." Apesar de usar o termo "queria", essa condicional reforça ainda mais que está conformada com a sua condição de vida. Embora sabendo que a autora viveu literalmente num "Quarto de Despejo", por ser favelada, vivendo em São Paulo, ela nos mostra através de seus pensamentos a aceitação de ser considerada uma cidadã de "quinta categoria", de viver num dos "lugares" definidos como o lugar do negro, ou seja, viver misturada com lixão, ratos, esgoto a céu aberto, situação que causa violência contra a cidadania de qualquer pessoa; principalmente contra a cidadania de uma mulher negra; e as desilusões da forma de Carolina ver o mundo vêem à tona: "Com as agruras da vida somos uns infelizes perambulando aqui neste mundo. Sentindo frio interior e exterior" (Ribeiro, 2002, p. 230. Ênfase minha).
\end{abstract}

A perspectiva adotada por Esmeralda Ribeiro é a de que Carolina Maria de Jesus se submetia e se conformava com o "lugar de negro" que a sua condição de moradora de favela Ihe imputava. Sua leitura, nesse sentido, escolhe uma via que vai ao contrário ao que de fato

\footnotetext{
${ }^{33}$ Desde 1982 até os dias atuais o coletivo Quilombhoje (nas figuras de Márcio Barbosa e Esmeralda Ribeiro) coordena a série Cadernos Negros, publicada em São Paulo desde 1978, criada por Cuti e Oswaldo de Camargo, entre outros.
} 
fez Carolina, pois escrever é tomar para si o poder da palavra e utilizar-se dele para transgredir. A expressão "lugar de negro", utilizada por Ribeiro, remete ao livro Lugar de negro (1982) da intelectual brasileira Lélia Gonzalez ${ }^{34}$, em parceria com Carlos Hasenbalg. Gonzalez define os lugares de brancos e de negros:

\begin{abstract}
As condições de existência material desta população negra remetem a condicionamentos psicológicos que têm que ser atacados e desmascarados. Os diferentes modos de dominação das diferentes formas de produção econômica existentes no Brasil parecem coincidir num mesmo ponto: a reinterpretação da teoria do "lugar natural" de Aristóteles. Desde a época colonial aos dias de hoje, a gente saca a existência de uma evidente separação quanto ao espaço físico ocupado por dominadores e dominados. O lugar natural do grupo branco dominante são moradias saudáveis, situadas nos mais belos recantos da cidade ou do campo e devidamente protegidas por diferentes formas de policiamento que vão desde os feitores, capitães do mato, capangas, etc., até a polícia formalmente constituída. Desde a casa grande e do sobrado até os belos edifícios e residências atuais, o critério tem sido o mesmo. Já o lugar natural no negro é o oposto, evidentemente: da senzala às favelas, cortiços, invasões, alagados e conjuntos "habitacionais" (...) dos dias de hoje, o critério tem sito simetricamente o mesmo: a divisão racial do espaço (Gonzalez, 1982, p.15).
\end{abstract}

A metáfora 'quarto de despejo' escolhida por Audálio Dantas para intitular o livro é tomada por Esmeralda Ribeiro como sinônimo para o "lugar de negro", do qual se deseja distância:

Numa primeira observação perguntaríamos o que o "Quarto de Despejo" tem a ver com o dito "lugar de negro". Tem tudo a ver, pois a palavra quarto metaforicamente nos dá a compreensão de que estamos falando do nosso íntimo, algo muito profundo que muitas vezes é desafiante expormos no papel. Agora, quando temos a palavra "quarto" com a palavra "despejo", a situação caminha para um complicador, é como se disséssemos que estamos desalojados de nosso próprio eu. "Quarto de despejo" significa o pior lugar que sobrou pra nós negros e negras na sociedade. É como se para nós o nosso destino fosse o "lixão, com ratos, baratas, esgoto a céu aberto", entre outras agruras que enfrentam os desprovidos de qualquer condição digna de vida (Ribeiro, 2002, p. 230).

De acordo com Ribeiro, a literatura de autoria feminina negra veiculada nos Cadernos Negros - representada em sua análise através dos contos de três escritoras selecionadas: Sônia Fátima da Conceição, Ruth Souza e Lia Vieira - já teria ultrapassado o "lugar de negro" ao qual, para ela, Carolina teria se adequado.

A utilização, no título deste trabalho, do nome do livro Quarto de Despejo, de Carolina Maria de Jesus foi para analisar nos trabalhos dessas três escritoras o sentimento de exclusão da sociedade, seja a exclusão social, ou, principalmente, a exclusão racial existentes nesses textos. Bem, sabemos que não podemos comparar

${ }^{34}$ Lélia Gonzalez nasceu em Belo Horizonte em 1935 e faleceu no Rio de Janeiro em 1994. É graduada em História/Geografia (UEG, 1958) e Filosofia (UEG, 1962), fez o mestrado em comunicação social e o doutorado em antropologia política, tem estudos também na psicanálise. É reconhecidamente uma das principais intelectuais negras brasileiras. Para acessar trabalhos da autora, consultar: <http://www.leliagonzalez.org.br/>. 


\begin{abstract}
as lembranças de Carolina com os códigos usados pelas escritoras negras contemporâneas em relação à elaboração de seus contos. É o sentido figurado da palavra "Quarto de despejo" o principal enfoque na minha análise. Lógico que o ato de escrever está interligado com os nossos valores, nossa vivência, nossa experiência individual e coletiva de ver o mundo. A intenção dessa análise é para saber se essas narradoras-autoras-personagens superaram no discurso narrativo a idéia de que somos nós, mulheres negras, a escória da sociedade; de fato elas transferem para os seus trabalhos que o nosso lugar é no universo e, portanto, não aceitamos os ditos "lugares de negros" (Ribeiro, 2002, p. 229-230).
\end{abstract}

A análise de Ribeiro reafirma o lugar fixo de Carolina dentro da diç̧ão da favela, da miséria e da falta de cidadania, reiterando o ponto de vista que o editor de Quarto de despejo imprimiu ao livro publicado. Ribeiro estabelece, ainda, um distanciamento evolutivo entre a autora e a literatura negro-feminina contemporânea, publicada nos Cadernos Negros, evolução pautada, inclusive, sob os códigos linguísticos através dos quais Carolina Maria de Jesus inscreveu suas composições memorialísticas, posto que a leitura comparada seja colocada no campo do intransitável: "não podemos comparar as lembranças de Carolina com os códigos usados pelas escritoras negras contemporâneas em relação à elaboração de seus contos".

No campo relativamente recente de investigação acerca da constituição de um discurso literário afrofeminino brasileiro, Carolina Maria de Jesus nos auxilia a pensar a possibilidade de uma enunciação que, além de trazer no plano do conteúdo as nossas contradições sociais históricas - cujas desigualdades em todos os níveis existem desde a construção de um país sob o peso da escravização de pessoas negras - também as evidencia no plano da forma, através de procedimentos estéticos que respondem à matéria social narrada. Evidentemente, uma leitura crítica comparativa entre a inscrição mais contemporânea de escritoras negras e Carolina Maria de Jesus revelará diferenças substanciais, como é de se esperar entre diç̧ões de indivíduos distanciados no tempo, no espaço e consequentemente, na elaboração identitária. No entanto, cremos que o exercício comparativo possa, antes de diminuir a expressão de uma para valorizar a expressão de outras, como de resto se depreende da leitura de Ribeiro, atentar para a discursividade afrofeminina brasileira constituída sob o jugo da diferença e não da diferenciação.

O lugar de subalternidade no qual Carolina Maria de Jesus e seu texto são colocados na leitura de Ribeiro nos remete ao ensaio de Gayatri Spivak (1988), onde o termo "subalterno" é apontado não apenas como uma palavra clássica para enquadrar o oprimido, mas como representação dos que não tem lugar em um contexto globalizante e excludente, 
no qual o "subalterno é sempre aquele que não pode falar, pois, se o fizer, já não o é" (Spivak, 1988, p. 275). A autora indiana refere-se à violência epistêmica, cuja tática de neutralização do Outro consiste em invisibilizá-lo, expropriando-o de qualquer possibilidade de representação, silenciando-o. A conclusão à pergunta "pode o subalterno falar?" é, portanto, negativa. O impacto do ensaio de Spivak é que ele desmancha qualquer ilusão na existência de uma possível perspectiva epistemológica nova que emanaria ao se dar voz ao subalterno, ou ao (pós-) colonizado, posto que sua fala é, de antemão, desqualificada e silenciada dentro da violência epistemológica colonial que constrói sua subjetividade precária. Com efeito, ao reafirmar o sentido estável e invariável do texto diarístico como exemplo do "lugar de negro", isto é, como discurso de índole conformada à miséria, e ao negar a característica de resistência de Carolina diante de seu cotidiano, Ribeiro condiciona a fala da autora a um lugar perene de subalternidade.

Por fim, o lugar de subalternidade em que a autora Carolina Maria de Jesus é colocada na leitura de Ribeiro reafirma o desentendimento comum que a sua presença como escritora causava, posto que ela não fosse aceita pelos moradores do Canindé depois de lançar seu primeiro livro - tida como delatora dos pobres da favela, ao sair de lá com os filhos recebeu pedradas dos vizinhos de barraco; não foi aceita pela classe média paulista, seus novos vizinhos da "sala de visitas"; foi repudiada pelos intelectuais das belas letras por escrever errado e por ser "exótica"; não foi acolhida pelos militantes da causa negra na época, que a julgaram politicamente incoerente (Santos, 2009, p. 48); e tampouco pelas feministas brancas: "Os dramas da mulher, mãe solteira, chefe de família, não foram incorporados ao acervo dos argumentos das feministas, escritoras ou não". (Meihy, 1998, p. 4); foi acusada de louca, pernóstica e histérica pelos órgãos de imprensa. Todos esses grupos exigiam uma fixidez identitária de Carolina que correspondesse ao lugar social que ela ocupava, implicando em sua escritura. Nesse movimento, portanto, negava-se o potencial de diferença que ela estava inscrevendo na literatura brasileira.

Como já dissemos, a hipótese de Meihy explica a explosão midiática e editorial caroliniana em razão do momento histórico: a "onda reformista" no início da década de 1960, caracterizada pela emergência de vozes dissonantes no cenário urbano, teria "permitido" uma melhor circulação da autora e sua obra. Segundo essa linha interpretativa, a sequência histórica que culminou no golpe militar em 1964 seria um dos motivos responsáveis pela queda de prestígio e descenso da carreira literária caroliniana, pois seu primeiro livro não se 
adequava "ao padrão proposto pelo golpe militar de 1964, que evitava a crítica social" (Meihy, 2003, p. 17, 18). Outro motivo, preponderante para o historiador, teria sido a "reação estranha da escritora em face da atitude impertinente da imprensa, da classe média paulistana e brasileira e da elite intelectual" (Meihy, idem).

Contudo, se o momento histórico foi condição de sucesso da autora, como pontua Meihy, poder-se-ia novamente inquirir por que este sucesso de público não foi o mesmo angariado por outros escritores para quem a literatura era tida como um espaço politicamente privilegiado de elaboração da identidade negra. Afinal, nos anos 60, segundo nos diz Heloisa Buarque de Hollanda "a relação direta e imediata estabelecida entre arte e sociedade era tomada como uma palavra de ordem e definia uma concepção de arte como serviço e superinvestida do ponto de vista de sua eficácia mais imediata" (Hollanda, 2004, p. 19). A análise do historiador, no entanto, aponta ainda um dado sutil: era das camadas pobres que viriam os sujeitos capazes de sacudir a opinião pública, isto é, o vetor operante sustentase mais numa chave de classe e não de raça ${ }^{35}$. Nesse sentido, a experiência da miséria da

\footnotetext{
${ }^{35}$ A "raça" sempre esteve presente na formação do pensamento social brasileiro. Oracy Nogueira (1955) divide a literatura que trata da "situação racial brasileira" em três correntes. A primeira, vinculada aos estudos afrobrasileiros (Nina Rodrigues, Arthur Ramos, Melville Herskovits, René Ribeiro, Édison Carneiro e Roger Bastide), volta-se à investigação da dinâmica aculturativa, preocupada então em delimitar a influência das culturas africanas no processo de constituição de uma cultura brasileira. A segunda corrente, denominada de histórica, é representada por Gilberto Freyre, que procura revelar as formas de inserção do negro na sociedade brasileira, os impactos resultantes e o lugar que tradicionalmente vem sendo atribuído à raça negra. Por fim, Oracy Nogueira sugere uma terceira corrente, a sociológica (Donald Pierson e, principalmente, os cientistas sociais envolvidos no Projeto Unesco), que valoriza em particular as variadas formas de interação racial entre brancos e negros. Alguns anos antes da publicação de Quarto de Despejo (1960), no inicio dos anos 1950, a UNESCO esforçava-se no combate à ideologia racista que sustentou a montagem e operação da máquina de morte nazista. Estimulada por análises que, na linha interpretativa de Gilberto Freyre, entendiam a sociedade brasileira como singularmente conformada sob a égide de uma democracia racial, a agência internacional coordenou uma grande pesquisa comparativa sobre as relações raciais em diferentes regiões brasileiras, conhecida como Ciclo UNESCO. Inicialmente, pretendia-se com esses estudos trazer ao mundo outros modos societários de cooperação entre raças. No entanto, no lugar de soluções para as violências raciais vividas em diversos contextos internacionais, a agência intergovernamental viu-se diante de um conjunto de dados sistematizados que afirmavam a existência do preconceito e da discriminação racial no Brasil, constatando uma enorme correspondência entre cor ou raça e status socioeconômico. A instituição internacional, criada logo após o holocausto, num tempo de crise profunda da civilização ocidental, volta-se para a periferia do mundo capitalista, almejando universalizar o que a sociedade brasileira teria de particular acerca da convivência pacífica entre as raças (Maio, 2000). Nesse sentido, em que pese a sistematização de um pensamento social brasileiro científico e articulado, o projeto tinha também fins políticos. Florestan Fernandes, ao elaborar o plano de pesquisa centrado em São Paulo, assegura que "o estudo deve ser projetado em bases científicas, mas tem uma origem e um fim que são igualmente extra-científicos: destina-se a uma instituição, a UNESCO, que o solicitou com o propósito de servir-se de seus resultados na reeducação social dos adultos e em sua política básica de aproximação das raças" (Bastide e Fernandes, 1959[1951], p. 324).
} 
favela é que tornava a fala de Carolina Maria de Jesus novidade e os marcadores de diferença de gênero e de raça apenas somavam na legitimidade de seu relato.

Esse ponto de vista é também o de Oswaldo de Camargo, conforme se nota neste trecho de entrevista concedida ao pesquisador Mário Augusto Medeiros da Silva em 29/07/2007, em ocasião de sua tese de doutorado:

Existe um certo segmento de negros, que por motivos vários estão frequentando
entidades, estão indo a palestras, estão tentando fazer uma vida intelectual etc. É
importantíssimo. [...] Cada vez que o negro brilhasse, aparecesse, era importante
para nós. Não importa em que setor, esporte... E a Carolina brilhou muito! E como
escritora! [...] Aí, o livro caiu como uma bomba! Por vários motivos. Era uma preta
favelada - fosse eu, não teria impacto assim. Fosse eu, revisor do Estadão? Pif!
[risos] Claro, né! - Favelada, trazendo com drama coisas extremas, fatos extremos,
de dramaticidade extrema... Tem histórias ali que são... Aquele menino que come
aquela carne mal assada e depois fica todo estourado! E outros fatos, né? E o livro
dela... E a editora também, né? A Editora Francisco Alves tinha um bom nome que...
e o livro repercutiu mundialmente (Silva, 2011, p. 219).

Tomando como princípio os temas nacionais da época de germinação do Quarto, temos que a questão da migração de legiões de pobres do interior para as grandes capitais contrastava com a euforia do desenvolvimento que empalidecia os dramas fragmentados pelos sofrimentos isolados. O progresso material coletivo foi a tônica das administrações de Juscelino Kubitschek e Jânio Quadros. Isto, em parte, devido aos debates travados a respeito da validade ou não da entrada do capital estrangeiro através das indústrias multinacionais que moldariam um novo perfil para a cara brasileira. Paradoxalmente, na fermentação dos debates sobre a industrialização nacional, em particular nos fins dos anos 50, a imposição do problema migratório aflorou, forçando a pensar nas consequências básicas da inversão populacional do campo para a cidade. Fatos concretos que evidenciavam o crescimento da marginalidade traziam o fenômeno da pobreza para os discursos, que tiveram que incluir as favelas no debate político. Neste cenário Carolina se faz mote, e seria impossível qualquer debate sobre o desenvolvimento sem passar por alguns dos argumentos contidos no livro (Meihy \& Levine, 1994, p. 20).

Considerando tratar-se ainda de um contexto em que, ademais, a intelectualidade nacional pensava e construía propostas em torno da ideia de "povo" e da cultura popular, a favela adentrava o imaginário comum em representações que nem sempre se amparavam em referenciais concretos. O que tornou o texto de Carolina indispensável para a reflexão, pois ali havia elementos que problematizavam a experiência de morar numa comunidade favelada, vista de forma romantizada pelo repertório da burguesia da época. 
O editor Audálio Dantas explica a popularidade do livro de Carolina devido ao impacto que ele representava, tendo em vista o imaginário construído das favelas como locus amenus. A respeito da experiência concreta da favela em comparação ao universo das canções que a romantizava, diz o jornalista:

O livro chamava a atenção da sociedade para as favelas. Trinta anos atrás S. Paulo não tinha tantas favelas como hoje, quando se fala em milhões de favelados, que andam por aí nessas periferias. Era uma aqui e outra ali, o que tinha mais era cortiço. A favela do Canindé era uma exceção. O problema da favela era conhecido, mas era abordado de uma forma romântica, como nos sambas Ave Maria no morro, Barracão de zinco. Com o diário, pela primeira vez, o problema veio com força, verdadeiro, pois veio lá de dentro. O fedor, o fedor que eu digo no meu prefácio, apareceu todo, inteiro, naquele momento (Levine \& Meihy, 1994, p. 160. Ênfase minha).

Carolina Maria de Jesus percorria diariamente longas distâncias em busca dos materiais que recolhia por onde passava e que garantiam seu sustento e dos seus filhos. Enquanto caminhava, conversava com transeuntes e principalmente, observava. Em consequência de seu constante andar pelas ruas, o olhar pan-ótico da narradora não se circunscreve apenas à favela, o que torna sua narração ainda mais interessante, pois se volta aos dois lados da cidade, buscando apreendê-la em sua totalidade. Narradora ácida e atenta do cotidiano da cidade, Carolina Maria de Jesus problematiza a nervura central do projeto desenvolvimentista ao mostrar a face negativa do progresso almejado.

A favela era um cenário perturbador para a industrialização anunciada como redentora da pobreza. Sua luta individual [de Carolina], uma aresta na suposta curva ascendente da história do Brasil. A dimensão internacional, garantida pelo noticiário especializado, colocava em destaque a problemática de uma nação que emergia no cenário capitalista com potencial a ser testado. Carolina, neste espaço, negra, era o contraste perfeito de uma sociedade, branca, que queria exibir-se moderna, progressista, organizada (Meihy \& Levine, 1996, p. 18,19).

Na cidade de São Paulo, diferentemente do Rio de Janeiro, as primeiras favelas estavam surgindo quando Quarto de Despejo chegou às livrarias. No entanto, os subespaços urbanos já eram tema constante nas letras dos sambas e da música popular urbana, "na qual, competentemente maquiados, recobriam sua degradação com promessas de felicidade conquistadas por contiguidade e vizinhança" (Lajolo, 1996, p. 39) ${ }^{36}$. A música popular,

\footnotetext{
${ }^{36}$ A obra de Carolina Maria de Jesus era algo original, do ponto de vista da linguagem, dentro de um universo de discursos que se compunha não somente pela idealização da favela proposta pela música popular. A primazia de inaugurar a temática da favela nos palcos brasileiros pertence ao musical Orfeu da Conceição, publicado em 1954, pela revista Anhembi. A peça de Vinicius de Moraes estreou em 1956, no Teatro Municipal do Rio de
} 
principalmente o samba dos salões, cantava a beleza idílica dos barracões de zinco, reservando aos moradores do morro um lugar "pertinho do céu". Ao longo do tempo, a imagética da favela constituiu uma parte importante do imaginário social que aciona e reitera a chave de interpretação do Brasil como terra harmoniosa. Marisa Lajolo chamou justamente de "favela cartão postal" (Lajolo, 1996, p. 39) as paisagens que o samba carioca criava, àquelas em que o morro aparecia como a sala de estar de Deus ${ }^{37}$.

A "favela de cartão-postal" foi consagrada por Herivelto Martins em "Ave Maria", gravada pela primeira vez em 1942:

\author{
Barracão de zinco sem telhado sem pintura \\ Lá no morro Barracão é bangalô \\ Lá não existe felicidade de arranha-céu \\ Pois quem mora lá no morro \\ Já vive pertinho do céu. \\ (Martins, Herivelto. 1942)
}

O sambista paulista Adoniram Barbosa (1910-1982) trata do mesmo tema de uma

maneira crítica, com toque de humor e ironia para falar das condições sociais desiguais que

narra:

Lá no morro quando a luz da light pifa

A gente apela pra vela que alumeia também (quando tem)

Janeiro, trazendo Haroldo Costa - ator oriundo do TEN, Teatro Experimental do Negro - no papel de Orfeu, contando ainda com a participação de Abdias do Nascimento e Léa Garcia, ambos do TEN.

37 Já diz a letra do samba: "Alvorada lá no morro, que beleza/ Ninguém chora, não há tristeza/ Ninguém sente dissabor/ O sol colorindo é tão lindo, tão lindo/ E a natureza sorrindo, tingindo, tingindo" (Cartola, 1960). Contudo, o samba carioca não era feito apenas de espaços metafóricos que transformavam a pobreza em lugar de felicidade, tornando a música popular "reduto indisputado de uma favela lírica e apaziguadora de consciências" (Lajolo, 1995, p. 12). Bezerra da Silva, por exemplo, compunha sambas em que o morro constituíase como lugar de uma coletividade que reclamava seu lugar na sociedade, como se vê nesta composição de 1983, revelando a face do morro que se reconhece e enaltece sua prática cultural própria: "Sou produto do morro/ Por isso do morro não fujo nem corro/ No morro eu aprendi a ser gente/ Nunca fui valente e sim conceituado/ Em qualquer bocada que eu chegar/ Eu sou muito bem chegado/ E no Canta Galo, na linha de frente/ Naquele ambiente sou considerado/ Sou produto do morro/ Sou produto do morro/ Sem pedir socorro pra ninguém/ Embarquei no asfalto da cruel sociedade/ Que esconde mil valores que no morro tem/ Tenho pouco estudo, não fiz faculdade/ $E$ atestado de burro não assino também/ Sou produto do morro/ É que a música é meu alento/ E o meu talento a Deus agradecer/ E nesse momento é a Ele que peço/ Se eu sou sucesso fiz por merecer/ Sou favelado, mas tenho muita dignidade/ E muita honestidade pra dar e vender/ Sou produto do morro" (Bezerra da Silva, 1983). Compositores "do asfalto" também escreveram canções de cunho crítico que viam o morro em suas condições sociais mais próximas da realidade desigual. É o caso, por exemplo, das canções O morro não tem vez de Vinicius de Moraes e Tom Jobim (1963): "O morro não tem vez/ E o que ele fez já foi demais/ Mas olhem bem vocês/ Quando derem vez ao morro/ Toda a cidade vai cantar/ Escravo no mundo em que estou/ Escravo no reino em que sou/ Mas acorrentado ninguém pode amar/ Mas acorrentado ninguém pode amar"; Feio não é bonito de Carlos Lyra e Gianfrancesco Guarnieri (1974): "Feio, não é bonito/ O morro existe, mas pedem pra se acabar/ Canta, mas canta triste/ Porque tristeza é só o que se tem pra cantar/ Chora, mas chora rindo/ Porque é valente e nunca se deixa quebrar/ Ama, o morro ama/ Amor bonito, amor aflito/ Que pede outra história". 
Se não tem não faz mal

A gente samba no escuro que é muito mais legal (e é natural)

Quando isso acontece há um grito de alegria

A torcida é grande pra luz voltar

Só no outro dia

Mas o dono da casa, estranhando a demora e achando impossível

desconfia logo que alguém passou a mão no fuzíl no relógio da luz.

(Barbosa, Adoniran. 1964).

Em outra perspectiva, a canção "Barracão", de autoria de Ary Carvalho e Ary Borges e eternizada por Elizeth Cardoso e Jacob do Bandolim, apresenta o barracão de zinco como um "pobretão infeliz" que de tão intrínseco às disparidades de condições sociais e distribuição de renda já se tornara tradição do país, e pede socorro à cidade:

\author{
Ai, barracão \\ Pendurado no morro \\ E pedindo socorro \\ À cidade a seus pés \\ Ai, barracão \\ Tua voz eu escuto \\ Não te esqueço um minuto \\ Porque sei \\ Que tu és \\ Barracão de zinco \\ Tradição do meu país \\ Barracão de zinco \\ Pobretão infeliz... \\ Ai, barracão \\ Pendurado no morro \\ E pedindo socorro \\ Ai, a cidade \\ A seus pés \\ Barracão de zinco \\ Barracão de zinco.
}

Contudo, o samba carioca não era feito apenas de espaços metafóricos que transformavam a pobreza em lugar de felicidade, tornando a música popular "reduto indisputado de uma favela lírica e apaziguadora de consciências" (Lajolo, 1995, p. 12). Podemos destacar o sambista Bezerra da Silva, compositor de sambas em que o morro constituía-se como lugar de uma coletividade que reclamava seu lugar na sociedade, como se vê nesta composição de 1983, revelando a face do morro que se reconhece e enaltece sua prática cultural própria:

Sou produto do morro

Por isso do morro não fujo nem corro

No morro eu aprendi a ser gente

Nunca fui valente e sim conceituado

Em qualquer bocada que eu chegar

Eu sou muito bem chegado 
E no Canta Galo, na linha de frente

Naquele ambiente sou considerado

Sou produto do morro

Sou produto do morro

Sem pedir socorro pra ninguém

Embarquei no asfalto da cruel sociedade

Que esconde mil valores que no morro tem

Tenho pouco estudo, não fiz faculdade

E atestado de burro não assino também

Sou produto do morro

É que a música é meu alento

E o meu talento a Deus agradecer

E nesse momento é a Ele que peço

Se eu sou sucesso fiz por merecer

Sou favelado, mas tenho muita dignidade

E muita honestidade pra dar e vender

Sou produto do morro" (Bezerra da Silva, 1983).

Compositores "do asfalto" também escreveram canções de cunho crítico que viam o morro em suas condições sociais mais próximas da realidade desigual. É o caso, por exemplo, das canções O morro não tem vez de Vinicius de Moraes e Tom Jobim (1963):

\author{
O morro não tem vez \\ E o que ele fez já foi demais \\ Mas olhem bem vocês \\ Quando derem vez ao morro \\ Toda a cidade vai cantar \\ Escravo no mundo em que estou \\ Escravo no reino em que sou \\ Mas acorrentado ninguém pode amar \\ Mas acorrentado ninguém pode amar
}

E Feio não é bonito de Carlos Lyra e Gianfrancesco Guarnieri (1974):

\author{
Feio, não é bonito \\ O morro existe, mas pedem pra se acabar \\ Canta, mas canta triste \\ Porque tristeza é só o que se tem pra cantar \\ Chora, mas chora rindo \\ Porque é valente e nunca se deixa quebrar \\ Ama, o morro ama \\ Amor bonito, amor aflito \\ Que pede outra história.
}

A ideia da favela cartão-postal é realmente desmantelada por Carolina Maria de Jesus, por exemplo, nessa passagem de Casa de Alvenaria onde se evidencia a surpresa do motorista do táxi, cujo olhar era o de quem consumia a imagem da favela que as canções criavam, e a sua reação ao constatar a paisagem mais complexa da favela real: 
Quando chegamos na favela o motorista ficou horrorizado! O seu olhar percorria de um local ao outro - Exclamou: - Credo! Que lugar! Então é isto que é favela! É a primeira vez que vejo favela. Eu pensava que favela era um lugar bonito por causa daquele samba: Favela, oi, favela. Favela que trago no meu coração... Mas haverá alguém que traz um lugar dêsse no coração? Enquanto o motorista fitava a favela eu pensava: com certeza o compositor do samba tinha uma mulher boa na favela. [...] O motorista condoeu-se vendo o aspéto infausto que a favela representa. É que êles estão habituados a ver a bela viola que é a cidade. Não conheçem os paes bolôrentos do país - as favelas (Jesus, 1961, p. 21).

Circulando em um espaço-tempo, os anos 1960,

extraordinariamente marcado pelos debates em torno do engajamento e da eficácia revolucionária da palavra poética, palavra que, naquela hora, se representava como muito poderosa e até mesmo como instrumento de projetos de tomada do poder" (Hollanda, 2004, p. 19).

a voz de Carolina Maria de Jesus, embora problematizando o imaginário social acerca das favelas, ecoou apenas superficialmente entre aqueles que traziam o pertencimento racial e o engajamento político comprometido com a equidade entre brancos e negros para a literatura.

Se a palavra de Carolina Maria de Jesus não fora considerada representativa pela intelectualidade negra brasileira na época - de acordo com Joel Rufino dos Santos, Abdias do Nascimento, por exemplo, não simpatizava com Carolina: "um dia ele me disse que a achava postiça, inocente útil de aproveitadores brancos" (Santos, 2009, p. 48, ênfase do original) nos Estados Unidos da América (EUA) a recepção de Carolina veio de encontro ao contexto de luta pelos Direitos Civis em que estava engajada a comunidade afro-americana. Sua palavra lá fez cair por terra a ideia altamente propalada de que o Brasil era exemplo de harmonia entre as raças e que vigorava por aqui uma democracia racial, sem conflitos.

Os norte-americanos estavam ávidos por saber das minorias e desde que Carolina Maria de Jesus fosse negra, pobre, e de um país "complicado", estavam dados os elementos para sua aceitação imediata. Além do mais, aqueles eram tempos de lutas pelos direitos civis nos EUA e isto promovia uma popularidade ao tema e uma simpatia natural para com o assunto. Para as elites acadêmicas norte-americanas, o tema Carolina despertava interesse especial, pois servia para contrastar com as teses já disseminadas pelos primeiros brasilianistas e demais estudantes da América Latina sobre a democracia racial. Os diários de Carolina mostravam uma versão árida da vida dos negros e isto era sombra nas luzes projetadas por autores que - como Frank Tannenbaum da Universidade de Columbia - acreditavam que no Brasil não existia preconceito racial e que ali realizava-se a buscada fusão étnica (Meihy \& Levine, 1996, p. 15).

Parece estar claro que a interpretação da autora, quanto aos aspectos de sua escritura negra, varia imensamente a partir do ponto de vista e do tempo em que foi lida. Pois, no presente, a literatura negra e periférica contemporânea - que margeia em seus textos 
experiências problematizantes dos lugares de gênero, de classe, de raça - lê Carolina como precursora. Ao passo que muitos trabalhos acadêmicos surgem em diversas universidades brasileiras e estrangeiras sustentando analises críticas que leem o texto caroliniano como expressão literária afrofeminina ${ }^{38}$.

Do ponto de vista desta dissertação, a palavra, para Carolina Maria de Jesus é fundamental para sua constituição subjetiva, e consequentemente, também para sua inserção no mundo enquanto sujeito. Este sujeito, que se constrói pela palavra, é mulher e é negra. Mas afinal, partindo de sua experiência social plural e multifacetada e de sua escritura híbrida, o que diz Carolina Maria de Jesus?

\footnotetext{
${ }^{38}$ Uma pesquisa nos principais bancos de teses pode confirmar a afirmação. Alguns trabalhos são citados na
} bibliografia sobre Carolina Maria de Jesus. 


\section{2 - Construção estética da experiência: O "ideal de poeta"}

Na minha opinião, escreve quem quer.

- Carolina Maria de Jesus

Minha palavra vale um tiro e eu tenho muito munição.

- Racionais MC's

O locus periférico/marginal inscrito no discurso literário configura, na contemporaneidade, pauta ativa das discussões acadêmicas e das que são empreendidas fora dos muros da universidade. Em 1983, Roberto Schwarz já adiantava: "a situação da literatura diante da pobreza é uma questão estética radical" (Schwarz, 1983, p. 8). Anos mais tarde, o mesmo crítico protagonizara um momento importante na reflexão acerca da literatura que emerge das margens dos centros urbanos, qual seja: a publicação de Cidade de Deus, de Paulo Lins (1997). Na ocasião, Schwarz considerou o romance um acontecimento, principalmente pelo interesse "explosivo" da temática trabalhada e pelo seu "ponto de vista interno e diferente" (Schwarz, 1999, p. 163). O atrativo do livro, entre outros, sustentava-se no fato de que os resultados da pesquisa realizada pela antropóloga Alba Zaluar sobre "Crime e criminalidade no Rio de janeiro", da qual Lins era assistente, foram "ficcionalizados do ponto de vista de quem era objeto do estudo" (Schwarz, 1999, p. 168). Além disso, aponta-se a máxima aproximação com o real como ponto positivo do romance, que envolve o leitor por "ter sido escrito por alguém que cresceu junto com o inferno que descreve", como é salientado na quarta capa do livro (Schwarz, 1999, p. 168) ${ }^{39}$.

\footnotetext{
${ }^{39}$ O próprio Lins, no entanto, não se considera vinculado à produção literária dita marginal ou periférica: "Foi o Ferréz quem começou com essa onda de literatura marginal, eu nunca tinha ouvido falar nisso, do jeito como está sendo apresentado atualmente [...] O que eu conhecia de escritores marginais tem a ver com a poesia marginal dos anos setenta e eu me lembro que o Leminski achava ruim esse movimento. Essa poesia foi esquecida pelos críticos por um bom tempo e agora o Roberto Schwarz e a Heloísa Buarque estão resgatando alguns autores. Quando eu fiz o livro, eu não pensei que eu era marginal; e o livro saiu pela Companhia das Letras, que não tem nada de marginal. 0 meu livro não tinha nada de marginal, a não ser o tema, se bem que a miséria e o urbano sempre apareceram na literatura - o José Lins do Rego e o Graciliano Ramos já falavam isso; sempre contrastavam o campo com a cidade. Eu penso que quem é engajado vai discutir a pobreza e a criminalidade - para mim a temática é que é marginal. O Marçal (Aquino), por exemplo, fez trabalhos com matadores; o (Fernando) Bonassi com detentos. Eu não vejo nada de marginal nas nossas obras, elas receberam o interesse da critica, da universidade, da imprensa" (Lins, In: Peçanha, 2006, p. 24).
} 
O final dos anos 1990 e o começo da década de 2000 representam um período fortemente marcado pela publicação de uma série de obras que sustentam o ponto de vista interno de sujeitos que ocupam espaços marginalizados da sociedade. Além de Paulo Lins com Cidade de Deus (Companhia das Letras, 1997) e Capão Pecado, de Ferréz (Labortexto, 2000 e nova edição em 2005 pela Objetiva); foram lançados no mercado obras cuja escritura centrava-se na experiência carcerária de autores presidiários, como Diário de um Detento, de Jocenir (Labortexto, 2001); Memórias de um Sobrevivente, de Luiz Alberto Mendes (Companhia das Letras, 2001); Sobrevivente André du Rap (do massacre do Carandiru), de André du Rap (Labortexto, 2002). Junto destes, uma série de livros centrados na tessitura narrativa imersa no cotidiano das periferias paulistanas são lançados: publica-se $O$ trem baseado em fatos reais, de Alessandro Buzo (Escortecci, 2000) e, do mesmo autor, Suburbano convicto: o cotidiano do Itaim Paulista (Edicon, 2004); Sacolinha, com Graduado em marginalidade (Escortecci, 2005) e Sérgio Vaz publicou A margem do Vento (Escortecci, 1995) e Pensamentos Vadios (Escortecci, 1999), entre outros ${ }^{40}$.

Ainda que cada obra tenha especificidades irredutíveis, o universo estético e o político dessas publicações podem ser problematizados a partir da definição engendrada por Ferréz para sua própria obra: trata-se de ser o tema, morar dentro do tema. De fato, diferente da discussão política e epistemológica entre ser sujeito ou objeto do discurso, a referencialidade é ponto de partida efetivo e afetivo e transfigura-se em discurso hiper-representativo sustentado em efeitos performáticos de "transparência" e "verdade". Em O pacto autobiográfico Philippe Lejeune pontua:

\begin{abstract}
É preciso parecer-se com seu livro, imitá-lo, colocá-lo em palavras, ser ele próprio. Você se transforma em homem-sanduíche de você mesmo. Inútil lembrar o que foi realmente o seu trabalho: um trabalho bem feito apaga seus vestígios. Impossível alegar que se escreve justamente para dizer algo diferente do que é transmitido pelos meios ordinários. Perigoso pontificar. Um único imperativo: visar a transparência (Lejeune, 2008, p. 199).
\end{abstract}

A mimese, no entanto, é conquista para quem esteve sempre na condição de objeto da representação artística e instaura, na literatura, pontos de fratura na narrativa oficial que privilegia determinadas enunciações em detrimento de outras.

O que se coloca hoje não é mais simplesmente o fato de que a literatura fornece determinadas representações da realidade, mas sim que essas representações não

\footnotetext{
${ }^{40}$ Uma discussão apurada sobre a literatura marginal pode ser encontrada na dissertação "Literatura Marginal": os escritores da periferia entram em cena (Nascimento, 2006).
} 
são representativas do conjunto das perspectivas sociais. O problema da representatividade, portanto, não se resume à honestidade na busca pelo olhar do outro ou ao respeito por suas peculiaridades. Está em questão a diversidade das percepções do mundo, que depende do acesso à voz e não é suprida pela boa vontade daqueles que monopolizam os lugares de fala (Dalcastagnè, 2002, p. 34).

A comparação entre a literatura periférica contemporânea e a enunciação de Carolina Maria de Jesus, tornada pública décadas atrás, sugere uma pulsão de discursos literários que problematizam a dicotomia inclusão/exclusão. Não pertencer ao cânone literário do país, é, mais do que estar excluído das narrativas oficiais, manter-se num lugar discursivo contrahegemônico. Trata-se, alinhado ao que o crítico Benjamin Abdala definiu em termos de crítica literária, como a leitura da margem produzida por quem a constitui: “É necessário, pois, que descentremos perspectivas: vamos observar as nossas culturas a partir de um ponto de vista próprio" (Abdala, 1996, p. 88). Ler os textos sob essa ótica nos possibilita o trânsito em um macrossistema produtor de sentidos, cuja obra de Carolina Maria de Jesus constitui parte fundamental, pois nos faz pensar que as obras dos autores periféricos de hoje é uma conquista do direito ao discurso que não começou agora, mas que vem sendo engendrada há muito tempo.

A diferença entre a obra caroliniana e esta literatura, entretanto, é também ruidosa, pois a luta que Carolina travou fora menos para "representar a cultura autêntica de um povo composto de minorias", como disse Ferréz na quarta capa do livro Literatura Marginal: talentos da escrita periférica, organizado por ele, onde se anuncia ao mundo a escrita de quem "tem muito a proteger e a mostrar, temos nosso próprio vocabulário, que é muito precioso, principalmente num país colonizado até os dias de hoje, onde a maioria não tem representatividade cultural e social" (Ferréz, 2001). Com efeito, a busca de Carolina está centrada num ponto diferente deste: ela reivindica o próprio ethos de escritora, isto é, a constituição da subjetividade na linguagem, a imagem de si no discurso como autora de literatura.

Este propósito se deflagra nas entrelinhas de um desejo sempre marcado por Carolina Maria de Jesus: ao ler seus escritos é comum encontrarmos a expressão ideal de poeta, como a lança de uma bussola a guiar seu caminhar cotidiano pela palavra. De fato, as passagens em que esta expressão surge em suas narrativas autobiográficas são múltiplas e frequentes. Tal ideal aponta para o significado subjetivo e eficácia concreta que a escritura representava para a autora: no plano da narrativa de suas experiências afetivas é construído como mediador, 
por exemplo, de sua escolha entre alguma independência intelectual e o papel normativo que, do seu ponto de vista, poderia caber à mulher nas relações de gênero dentro do matrimônio:

O senhor Manuel apareceu dizendo que quer casar-se comigo. Mas eu não quero porque já estou na maturidade. E depois, o homem não há de gostar de uma mulher que não pode passar sem ler. E que levanta para escrever. E que deita com lápis e papel debaixo do travesseiro. Por isso é que eu prefiro viver só para o meu ideal (Jesus, 1960, p. 50).

26 de julho de 1958: Nossos olhares encóntraram-se e eu lhe disse: vê se não volta mais aqui. Eu ja estou velha. Não quero homens. Quero so os meus filhos. Ele saiu. Ele é muito bom é iducado. E bonito. Qualquer mulher há de ter orgulho de ter um homem bonito como êle é. Agradavel no falar. Não perturba. Não tem vicios. Mas os homens aborrece de mim porque eu so sei falar de livros. E eu sendo livre, posso viver com a concrétisação do meu ideal, que e a literatura ${ }^{41}$. (Jesus, 1960, p, 100).

16 de novembro de 1959: Quando cheguei na favela que reboliço! no meu barraco roupas na cama, esta semi-molhadas. Recolhi pensando que ia chover. Estendi-as. o solo esta tão sujo. que da nôjo. Depois que passei a escrever difinitivamente não tenho tempo para limpêsa. Eu estava agêitando o barraco quando o senhor Manoel chegóu. Que ódio. Eu já disse-lhe, que quero viver so pórque tenho muitas obras para cóncluir. Êle é caçête. Não dêixa eu ler. A Dona Flasina estava aqui, e dizia: que eu luto demaes. Ela despediu-se o senhor Manoel ficou e disse-me Amanhã eu vóu receber e dóu-te dinheiro. Não adianta o senhor me dar dinheiro, porque eu não vou viver com o sénhor Se Deus me ajudar eu quero dedicar o resto de minha vida a literatura - percibi que vim ao mundo para góstar dos livros e não vim para góstar do homem. O homem tem que viver com a mulher que gosta d ele Ele diz-me que vae reçeber herança. pensando que vai atrair-me. Eu não tenho ambição pelo dinheiro. Tenho pela arte. gosto de ver um livro bem encadernado. Um quadro etc. E um homem que sabe ler (Citado por: Perpétua, 2000, p. 342).

\section{O ideal de poeta é também acionado pela autora como parte constitutiva de sua}

individualidade, em resposta a uma conjuntura social que projetava a mulher negra fora do campo epistêmico $^{42}$, conforme a narrativa da fala do vizinho:

23 de julho. Liguei o radio para ouvir o drama. Fiz o almoço e deitei. Dormi uma hora e meia. Nem ouvi o final da peça. Mas, eu já conhecia a peça. Comecei fazer o meu diário. De vez em quando parava para repreender os meus filhos. Bateram na porta.

\footnotetext{
${ }^{41}$ As partes destacadas em itálico não foram publicadas na edição de Quarto de despejo editada por Audálio Dantas.

42 O conceito de "epistemicídio" é desenvolvido pela filosofa Sueli Carneiro e se refere às formas de conhecimento que não são reconhecidas pelos mecanismos sociais eurocêntricos: "Alia-se nesse processo de banimento social a exclusão das oportunidades educacionais, o principal ativo para a mobilidade social no país. Nessa dinâmica, o aparelho educacional tem se constituído, de forma quase absoluta, para os racialmente inferiorizados, como fonte de múltiplos processos de aniquilamento da capacidade cognitiva e da confiança intelectual. É fenômeno que ocorre pelo rebaixamento da auto-estima que o racismo e a discriminação provocam no cotidiano escolar; pela negação aos negros da condição de sujeitos de conhecimento, por meio da desvalorização, negação ou ocultamento das contribuições do Continente Africano e da diáspora africana ao patrimônio cultural da humanidade; pela imposição do embranquecimento cultural e pela produção do fracasso e evasão escolar. A esses processos denominamos epistemicídio" (Carneiro, 2005).
} 
Mandei o João José abrir e mandar entrar. Era o Seu João. Perguntou-me onde encontrar fôlhas de batatas para sua filha buchechar um dente. Eu disse que na Portuguesinha era possível encontrar. Quiz saber o que eu escrevia. Eu disse ser o meu diário. - Nunca vi uma preta gostar tanto de livros como você. Todos tem um ideal. O meu é gostar de ler. O seu João deu cinquenta centavos para cada menino. Quando ele me conheceu eu tinha só os dois meninos. Ninguém tem me aborrecido. Graças a Deus (Jesus, 1960, p. 27. Ênfase minha).

Os atos de escrita e leitura são fundantes do sujeito Carolina Maria de Jesus, visto que a constituição deste seu ideal engendra um destino manifesto de poeta; aparece como ética de vida, no sentido de justificar suas convicções; e presta-se a modelar sua persona pública ante as interpelações sociais.

A palavra escrita, para a autora Carolina Maria de Jesus, constituía recurso fundamental de constituição de si enquanto sujeito do processo histórico e simbólico, era na escrita que ela se defendia e respondia às situações cotidianas em que sua condição de igualdade Ihe era negada - quaisquer que fossem os termos desta negação - como ilustra esta passagem de Quarto de despejo em que a discriminação se materializa sobre suas condições de consumo:

6 de janeiro - Deixei o leito a 4 horas, liguei o radio e fui carregar água. Que suplicio entrar na água de manha. Eu sou frienta! Mas a vida é assim mesmo. Os homens estão saindo para o trabalho. Levam as meias e os sapatos nas mãos. As mães prendem as crianças em casa. Elas ficam ansiosas para ir brincar na água. As pessoas de espírito jocoso dizem que a favela e a cidade náutica. Os outros dizem que e a Veneza Paulista. ... Eu estava escrevendo quando o filho do cigano veio dizer-me que o seu pai estava chamando-me. Fui ver o que ele queria. Começou queixar-me. Começou queixar-se que encontra dificuldades para viver aqui em São Paulo. Sai para procurar emprego e não encontra. Disse que vai voltar para o Rio, porque lá é melhor para viver. Eu disse-lhe que aqui ganha-se mais dinheiro. - No Rio ganha mais - afirmou - Lá eu benzia crianças, vendia carne e ganhava muito dinheiro. Percebi que o cigano quando conversa com uma pessoa, fala horas e horas. Até a pessoa oferecer dinheiro. Não é vantagem ter amisade com cigano .... Quando eu ia sair, ele disse-me para eu ficar. Saí e fui no emporio. Comprei arroz, café e sabão. Depois fui no Açougue Bom Jardim comprar carne. Cheguei no açougue, a caixa olhou-me com um olhar descontente.

- Tem banha?

- Não tem.

- Tem carne?

- Não tem.

Entrou um japonês e perguntou:

- Tem banha?

Ela esperou eu sair para dizer-Ihe:

- Tem.

Voltei para a favela furiosa. Então o dinheiro do favelado não tem valor? Pensei: Hoje eu vou escrever e vou chingar a caixa do Açougue Bom Jardim.

Ordinária! (Jesus, 1960, p. 44, 145).

Para a autora, o poeta é alguém imbuído de uma missão social: "Os politicos sabem que eu sou poetisa. E que o poeta enfrenta a morte quando ve o seu povo oprimido" (Jesus, 
1960, p. 40). À condição de poeta, Carolina Maria de Jesus atribui significados em contraponto à ideia do escritor, pertencente à elite letrada, como lemos no exemplo abaixo. No segundo exemplo citado, a temática neoclássica surge para autenticar as dificuldades de ser poeta nas condições que a autora vivia em seu tempo presente:

- Eles falava que eu sendo poetisa era para estar entre os fidalgos. Que os poetas
são pessoas finas que andam com as unhas esmaltadas e luvas. Sorri. Pórque eles
não conhecem os poetas. O poeta é um infeliz conhece so agruras no seu roteiro
neste hemisfério (Citado por: Perpétua, 2000, p. 328).
15 de junho de $1958:$ O que me vale é que eu não sou granfina, cato papel, cato
estôpa esterco para jardins, ferro e vendo, e arranjo qualquer coisa para as crianças
comer. Ensinei as crianças comêr pão duro. Sei que pão duro não alimenta. Mas,
quem não tem sapatos, anda descalço. Eu estou dessalojada nesta época atual.
porque eu tenho muita saúde. sou Capás de comer até um boi. Eu devia ter nascido
em 1600 . Os escritores daquela época, so falam em flôres estrêlas e amôr (Citado
por Perpétua, 2000, p. 334$)$. ${ }^{43}$

Carolina Maria de Jesus por vezes dialoga na escrita com as obras literárias, sobretudo românticas, que teve acesso, muitas vezes mobilizando os recursos presentes em tais obras para narrar a própria experiência. A inscrição da experiência através da reescrita dos lugares comuns da literatura canônica que a autora pôde acessar revela o lugar da leitura no seu exercício de construção de si como autora. As qualidades que o poeta deve cultivar, oriundas do repertório romântico, são presentes nos excertos abaixo em que se valoriza o patriotismo do poeta:

10 de junho de 1958: tudo que escrevo aqui não é para engrandecer-me pórque eu
não tenho vaidade. É que sou poetisa. E o poeta, gosta da sua gente gosta da sua
pátria. E revoltam quando ve o seu povo infausto E o odio do poeta, recae
unicamente no governo. Que se for letargico será criticado. E se for dinâmico sera
enaltecido (Citado por Perpétua, 2000, p. 249).

5 de junho de 1958: O senhor tem todos os diplomas completo e eu tenho so dôis anôs de grupo escolar. sou preta. E se amo a patria, e ambiciono o Brasil suplantando outrós paizes é porque tenho o pensamento poetico. E o póeta gosta de ver a sua patria na frente e o seu povo feliz (Citado por Perpétua, 2000, p. 334).

O sentimento ufanista espelhava a convenção literária romântica, da qual a autora filtrou algumas partes e procurou aplicá-las em seu texto. Nesse sentido, o enaltecimento do potencial nacional, das belezas naturais, riquezas e potenciais do país funcionava para Carolina Maria de Jesus mais como código estilístico que como convicção, pois, em

\footnotetext{
${ }^{43}$ As citações de trechos do diário de Carolina Maria de Jesus cuja referência recai no trabalho de Perpétua não foram publicados originalmente na edição de Audálio Dantas e permaneciam inéditos até a publicação, em forma de anexo, na tese da pesquisadora.
} 
contraposição, ela reiterava constantemente a sua condição de "rebotalho" do tecido social, posto estar à margem da própria condição de cidadania que suas condições materiais alinhadas ao descaso do poder público the ocasionava, bem como aos seus companheiros de infortúnio. A conexão entre a convenção literária possível - a que a autora pode ter acesso e a narrativa da experiência autobiográfica pode ser observada no exemplo abaixo:

19 de maio de 1958: Deixei o leito as 5 horas. Os pardais já estão iniciando a sua sinfonia matinal. As aves deve ser mais feliz que nós. Talvez entre elas reina a amizade e igualdade. (...) O mundo das aves deve ser melhor que o dos favelados, que deitam e não dormem porque deitam-se sem comer.

... O que o senhor Juscelino tem de aproveitavel é a voz. Parece um sabiá e a sua voz é agradável aos ouvidos. E agora, o sabiá está residindo na gaiola de ouro que é o Catête. Cuidado sabiá, para não perder esta gaiola, porque os gatos quando estão com fome contempla as aves nas gaiolas. E os favelados são os gatos. Tem fome.

... Deixei de meditar quando ouvi a voz do padeiro:

- Olha o pão doce, que está na hora do café!

Mal sabe êle que na favela é a minoria quem toma café. Os favelados comem quando arranjam o que comer. Todas as familias que residem na favela tem filhos. Aqui residia uma espanhola Dona Maria Puerta. Ela comprou um terreno e começou a economisar para fazer a casa. Quando terminou a construção da casa os filhos estavam fracos do pulmão. E são oito crianças.

... Havia pessoas que nos visitava e dizia:

- Credo, para viver num lugar assim só os porcos. Isto aqui é o chiqueiro de São Paulo.

... Eu estou começando a perder o interesse pela existência. Começo a revoltar. E a minha revolta é justa.

... Lavei o assoalho porque estou esperando a visita de um futuro deputado e êle quer que eu faça uns discursos para êle. Êle disse que pretende conhecer a favela, que se for eleito há de abolir as favelas.

... Contemplava extasiada o céu côr de anil. E eu fiquei compreendendo que eu adorava o meu Brasil. O meu olhar pousou nos arvorêdos que existe no inicio da rua Pedro Vicente. As folhas movia-se. Pensei: elas estão aplaudindo este meu gesto de amor a minha Patria. (...) Toquei o carrinho e fui buscar mais papeis. A Vera ia sorrindo. E eu pensei no Casimiro de Abreu, que disse; "Ria criança. A vida é bela". Só se a vida era boa naquele tempo. Porque agora a época está apropriada para dizer: "Chora criança. A vida é amarga" (Jesus, 1960, p. 35, 36).

Antônio Cândido, em seu "Os olhos, a barca e o espelho" (Candido, 2003), ao tratar da escrita de Lima Barreto, faz um exercício de ler no texto autobiográfico elaborações estilísticas próprias ao discurso ficcional. "Ainda aqui, portanto, verificamos o encontro favorável da confissão, da análise social e do achado estilístico, fazendo o documento biográfico deslizar para a criação literária" (Candido, 2003, p. 47).

No trecho supracitado de Carolina Maria de Jesus igualmente se observa, na narrativa de um mesmo dia, a construção estética dando forma à narrativa cotidiana diarística. Os favelados, que deitam e não dormem, são colocados em contraponto ao mundo das aves, do 
qual pertence o representante máximo do poder político no período - "o presidente da República JK, sabiá que estando preso numa gaiola é alvo de constante vigília por aqueles que têm fome, os favelados". A sequência do texto expande-se num teor dramático e pungente, ao abrir espaço para contar a história da espanhola que se sacrificou tanto para juntar economias e sair da condição de moradora de barraco que o preço a pagar fora a saúde de seus próprios filhos. Ao caráter sensível e emocionante da narração desta pequena história muda-se abruptamente o tom para dar vazão à violência do olhar exterior dos que reificavam os moradores da favela, rebaixando-os à condição de animais: porcos no chiqueiro. Como síntese destes dois atos - o drama da espanhola e o julgamento agressivo dos que excluíam os favelados da condição de humanidade - vem à tona a revolta da narradora diante da existência, revolta que ela sabe ser justa. A narrativa prossegue com o acréscimo de outro elemento: a presença de um aspirante a cargo público representativo que buscava em Carolina vantagens próprias, pois o poder de sua escrita era tamanho que políticos a procuravam para escrever discursos. No final do excerto, o retorno ao campo do tema ufanista de adoração à Pátria, mas agora acrescentando uma releitura do verso do poeta romântico para construir sob sua rubrica a rasura de um novo sentido, aquele possível à experiência da escritora: "Chora criança. A vida é amarga".

Robert Levine conta que costumava perguntar aos seus alunos do curso de "Introdução à história da América Latina", lecionado por ele na State University de Nova York, do qual Quarto de despejo era leitura obrigatória, "por que essa mulher era tão dócil?" (Levine, 1994, p. 202). Ele não explica os motivos para considerá-la assim e nem as respostas que recebia dos seus alunos, deixando apenas a pergunta, que de resto, afirma e sentencia algo. A "docilidade de Carolina", à parte poder ser percebida por estratégias de alguma versão estrangeira da narrativa, parece ter sido interpretada pelo professor através de sua linguagem, que como o excerto acima demonstra, é fragmentária. Entretanto, o filtro que a autora faz de elementos do discurso literário canônico e a transfiguração destes para a narrativa da experiência da falta, considerando a formação do nosso sistema literário nacional em todo pautado por seleções de classe (burguesa), de gênero (masculino) e de raça (branca), é em si o oposto exato de uma condição dócil.

Afora isso, a missão do poeta, àquela que Carolina considera também sua, não se enquadra em perspectivas ideológicas alinhadas a pautas ou programas políticos definidos e em geral é edificada na própria experiência social da autora: 
Deixei o leito furiosa. Com vontade de quebrar e destruir tudo. Porque eu tinha só feijão e sal. E amanhã é domingo... Fui na sapataria retirar os papeis. Um sapateiro perguntou-me se meu livro e comunista. Respondi que era realista. Êle disse-me que não é aconselhavel escrever a realidade (Jesus, 1960, p. 105).

8 de novembro de 1959: Ela achou graça quando eu galgava ós degraus. E não olhava para baixo pórque fico tonta. penso que vóu cair. para mim as alturas é um suplicio. Tenho que viver sempre nos baixos. É porisso que eu luto para sair da favela e não consigo. Ela perguntóu-me se é pressão alta? - Citei-lhe que sou póetisa E o póeta não pode suportar as alturas (Citado por Perpétua, 2000, p. 335).

Em oposição ao que ela nomeia "poeta fidalgo" ou "poeta da sala de visitas", seu pertencimento se conjuga nas categorias de "poeta dos pobres" e "poeta do lixo", sempre atento aos desmandos dos políticos.

... Mas eu já observei os nossos politicos. Para observá-los fui na Assembleia. A sucursal do Purgatorio, porque a matriz é a sede do Serviço Social, no palacio do Governo. Foi lá que eu vi ranger de dentes. Vi os pobres sair chorando. E as lagrimas dos pobres comove os poetas. Não comove os poetas de salão. Mas os poetas do lixo, os idealistas das favelas, um expectador que assiste e observa as trajedias que os politicos representam em relação ao povo (Jesus, 1960, p. 54).

Segundo Carolina Maria de Jesus, para "várias pessoas" o fato de que ela escrevia parecia ser incompatível com sua situação econômica: “- Você não é tão pobre como diz: Já vi varias pessôas dizer que eu estou fantasiada de pobre. Se eu tivesse recurso, mandaria imprimir o meu livro. Porque o ideal também faz parte da vida" (Jesus, 1996a, p. 83). E a condição de poeta imergia algumas vezes em angústias e pesares:

Quando eu percebi que sou poetisa fiquei tao triste. O dia que o senhor Vili Aureli disse-me: Carolina, voçê é poetisa, naquêle dia eu sepultei alegria que acompanhava-me igual a minha sombra Até aquela data o meu coração trajava-se com as côres alegres. Depois passou a usar a côr rôxa. - E agora... usa a preta. Acho que sou preta interiormente e exteriormente (Jesus, 1996a, p. 83).

A palavra escrita tem poder e não é frívola, ao contrário, ocasiona em Carolina o peso das ideias em constante ebulição:

A prutuguesa que deu-me os papeis disse-me que me conheçe faz muitos anos. Disse-me que todos os poetas ficam loucos. Eu disse-lhe: que quando percebi que eu sou poetisa fiquei triste porque o excesso de imaginação era demasiado. Que examinei o cérebro no Hospital das Clinica Que o exame deu que sou calma. Que eu iduquei imensamente o meu cerébro. Que não dêixei as idéias dominar-me. Que fiquei triste do desprêso do povo pelo poeta. Mas agora estou na maturidade e não impreciono com as filancias de quem quer que sêja... (Jesus, 1996a, p. 84).

28 de maio de 1959: Dizem que antes de nos vir ao mundo pidimos a Deus o que queremos ser aqui na terra. Entao eu fui tôla. porque pedi pensamento poetico, dramatico, e romantico com toda bagagem literária que eu carrego no meu cerebro... Não tenho socêgo. (Citado por: Perpétua, 2000, p. 337).

12 de junho de 1959: Devemos arranjar um mêio de vida. Eu não aprendi oficio pórque as ideias literarias não me permite fazer outra coisa que não sêja escrever 
Eu considero estas ideias literarias que não me dêixa um segundo de preçeptôra minha sinhá, minha tutóra (Citado por: Perpétua, 2000, p. 337).

No entanto, cada ocasião exige um tipo de colocação própria para a palavra poética e a autora demonstra sensibilidade apurada para tal:

7 de junho de 1958: Quase tôdas as pessoas possue um ideal mas, não pode cultivar devido o trabalho que lhes rouba o tempo e lhes deixa esgotados será que e so o poeta que da valôr as pessôas? Créio que sim. porque o poeta real procura estudar para conhecer as frases aveludadas para utilisa-la com o povo. [...] para viver feliz nêste mundo, precisa ser uma pessôa igual a eu. Que quando é preciso agir esquêço as frases de gazes. Minhas palavras impôe respêito, e o meu olhar tambem, é autóridade (Citado por: Perpétua, 2000, p. 334).

\section{O "pensamento poético" preenche grande espaço no cotidiano da autora, parecendo}

ser, da forma como ela constrói no texto, inevitável:

Eu lutava para ficar livre do pensamento poético que me impedia o sono. Percebi que andando de um lado para outro o pensamento poético dissipava-se um pouco. [...] quando sentia fome as ideias eram mais intensas [...] creio que já familiarizei com essa miniatura de calvário. Quando percebo que estou exausta, sento com lápis na mão e escrevo (in: Meihy, 1994, p. 188-189).

11 de dezembro de 1959: Contei-Ihes que custei descobrir que era póetisa Que pensei que era enfermidade Que o meu pensamento é classico e eu fui obrigada a ler o classico para compreender os derivados das frases. Que eu não posso sentar. Quando sento os versos emana-se.

- Onde estudóu?

- Tenho so dôis anos de grupo

- A senhóra tem o don Natural.

Eu reconheço que sou agraciada com o êxesso de imaginação Mas, eu estudei para aprender escrever. Dêsde que aprendi ler lêio todos os dias. Despedi dizendo que encóntrei paz andando de um lado para o outro, para dissipar as ideias.

- Onde encontra livros para ler?

- Eu cato papel, e acho no lixo. e ganho alguns (Citado por: Perpétua, 2000, p. 337).

\section{Embora houvesse aqueles para quem o seu exercício cotidiano de escrita fosse} interpretado como sinal de ociosidade, afinal, dos pobres esperava-se apenas o trabalho:

A assistência estava chegando. Vinha visitar o português que vende doces. Dia 28 de julho eu fui visitá-lo. Êle queria uma Assistencia. Aludiam que êle não paga o IAPTC ${ }^{44}$ e não vinham. Quando cheguei na favela fui visitá-lo. Êle estava gemendo e tinha duas senhoras purtuguesas que lhe visitava. Perguntei-lhe se estava melhor. Disseme que não. A purtuguesa perguntou-me:

- O que é que a senhora faz?

- Eu cato papel, ferro, e nas horas vagas escrevo.

Ela disse com a voz mais sensata que já ouvi até hoje:

- A senhora vai cuidar de sua vida! (Jesus, 1960, p. 102, 103).

O trabalho, contudo, é também resignificado por ela a partir das qualidades próprias dos poetas:

44 Antigo Instituto de Aposentadoria e Pensões dos Transportadores de Cargas, hoje extinto e absorvido pelo INSS. 
30 de junho de 1958: O senhor Manoel vêio pedir para eu cosinhar para êle comida especial que êle está dóente Vóu cosinhar pórque eu sou esperta para fazer cerviço. E ha quem diz, que o poeta e preguicoso. Vitôr Hugo condenava o improdutivo (Citado por: Perpétua, 2000, p. 335).

6 de agosto de 1958: Eu ainda tenho disposição para fórmar uma lavoura e colher o que eu plantar. A pessoa enquanto vive-se não deve ter preguiça. E ha pessôas que diz que o póeta é preguiçoso. Tenho que defender o poeta pórque sou do rol (Citado por: Perpétua, 2000, p. 335).

O enfermêiro disse-me que me conheçe. E que eu não sou priguiçosa - gostei do êlogia. Pensei: estou fora de moda porque as ma linguas dizem, que o poeta é preguiçôso (Jesus, 1996a, p. 48).

Neste trecho de Quarto de Despejo, nota-se como a palavra escrita possibilita para a narradora Carolina a construção de si em outras realidades, numa narrativa utópica que formaliza esteticamente e em outro plano a experiência histórica da autora. Etimologicamente, a palavra de origem grega "utopia" significa o não-lugar e colabora na tensão entre real e ficção na elaboração do diário:

Eu deixei o leito as 3 da manhã porque quando a gente perde o sono começa a pensar nas miserias que nos rodeia. (...) Deixei o leito para escrever. Enquanto escrevo vou pensando que resido num castelo cor de ouro que reluz na luz do sol. Que as janelas são de prata e as luzes de brilhantes. Que a minha vista circula no jardim e eu contemplo as flores de todas as qualidades. (...) É preciso criar este ambiente de fantasia, para esquecer que estou na favela (Jesus, 1960, p. 59, 60, ênfase minha).

Contudo, a condição de poeta é comumente pontuada em suas narrativas como algo atribuído por outrem. E não por qualquer um, mas especificamente por pessoas de maior prestígio social que a autora: ocorreu na infância através do diagnóstico do médico espírita Eurípides Barsanulfo e, anos mais tarde, através da fala do jornalista Willy Aureli, a quem Carolina Maria de Jesus cita diversas vezes.

Dia cinco de fevereiro de 1941, eu fui na redação das Folhas, na rua do Carmo. Falei com o distinto jornalista Sr. Vili Aureli. Mostrei-Ihe os meus escritos e perguntei o que era aquilo que eu escrevia. Ele olhou-me minuciosamente, sorriu e respondeume: - Carolina, voçê é poetisa! - levei um susto, mas não demonstrei. O meu coração acelerou-se, como se fosse um cavalo de corrida, pensei: - ele disse que eu sou poetisa, que doença será esta. Será que isto tem cura? Será que vou gastar muito dinheiro para curar essa enfermidade? - Pensei: circula um boato que os poetas são inteligentíssimos. (...) Dirigi à praça da Sé e tomei o bonde, Bresser, ao meu lado ia um senhor lendo a Fôlha da Manhã. Perguntei-lhe: - o que quer dizer poetiza? - É mulher que tem o pensamento poético. Porque, pergunta, a senhora é poetisa? O jornalista disse-me que sim. E a senhora pretende escrever alguns livros? Fiquei orrorizada interiormente e o meu coração acelerou-se. Então a poetisa tem que escrever livros? Eu não tenho condição para ser escritora. Não estudei! Silenciei com receio de dizer banalidades. (...) eu hei de saber o que é ser poetisa e quais são as vantagens ou desvantagens que existem para um poeta. Procurei numa livraria um livro de poeta, porque o senhor que estava no ônibus disse que o poeta escreve 
livros, pedi: - Eu quero um livro de poeta - o livreiro deu-me: - Primaveras, de Casimiro de Abreu. E assim fiquei sabendo o que era ser poetisa. (...) Fiquei sabendo que as palavras cadenciadas eram rimas. Pensei: Eu não devo dizer para as vizinhas que sou poetisa. Elas não sabem o que é isso e não vão crer. E eu, não quero ser ridicularizada. No fundo do meu coração eu agradeço ao saudoso e ilustre Sr. Vili Aureli, por dizer-me que sou poetisa, porque, com dois anos de grupo escolar eu não ia perceber (Meihy \& Levine, 1994, p. 186).

O ideal de Carolina a tornava uma escritora orgânica, frutificando sua escrevivência. O conceito de "escrevivência", construído pela escritora Conceição Evaristo, assenta-se em três elementos formadores: corpo, condição e experiência: "a escrita de um corpo, de uma condição, de uma experiência negra no Brasil" (Evaristo, 2007, p. 20). Não obstante, de forma paradoxal, o ideal de poeta de Carolina Maria de Jesus foi "regredindo" após a sua estreia na literatura, devido a sua desilusão e às consequências que teve que responder em virtude do emparedamento $^{45}$ quanto ao lugar de emanação de sua voz autoral, fixada no epíteto "escritora favelada" que a consagrara, mas cuja imagem restringia seu campo de composição discursivo ao espaço narrativo da favela, tornando sua escrita pós-Canindé irrelevante para o público leitor que consumira suas palavras para depois descartá-las rapidamente. De fato, Carolina enquanto narradora era deveras interessante para um público leitor curioso a ouvir a "voz do outro". o "outro", entenda-se: subalternizado, estando longe, na favela, e tendo direito apenas a dar testemunho dela.

Para os estrangeiros, mais que qualquer coisa, o Quarto e os demais livros de
Carolina desmascararam o mito da democracia racial brasileira, aceito como
atestado da cultura brasileira e que até então não havia sido mexido. Foi,
paradoxalmente, uma mulher negra, da favela, quem expôs as contradições entre a
percepção cultural da elite e a realidade dos pobres. Mas aos olhos brasileiros era
dif́cil reconhecer essas evidências através de Carolina, até porque ela própria
reforçava em certas passagens o preconceito racial. A crítica brasileira discutiu a
obra de Carolina em termos bem claros e evidentes para qualquer análise do
discurso. Ela foi mostrada nos anos JK como sendo uma "favelada preta", "mulher
pobre e de cor", "vítima da miséria". Os acadêmicos falavam de sua produção como
das "classes subalternas", escrita dos "grupos oprimidos", "subliteratura". No
governo sucessor de Juscelino, a linguagem ficou ainda mais feroz: para os

${ }^{45}$ Cruz e Souza já clamava em seu texto em prosa O emparedado, que integra o livro Evocações, um febril protesto contra as teorias racistas que enclausurava o sujeito negro entre teorias e discriminações no século XIX: “Não! Não! Não! Não transporás os pórticos milenários da vasta edificação do mundo, porque atrás de ti e adiante de ti não sei quantas gerações foram acumulando, pedra sobre pedra, pedra sobre pedra, que para aí estás agora o verdadeiro emparedado de uma raça. Se caminhares para a direita baterás e esbarrarás, ansioso, aflito, numa parede horrendamente incomensurável de Egoísmos e Preconceitos! Se caminhares para a esquerda, outra parede, de Ciências e Críticas, mais alta do que a primeira, te mergulhará profundamente no espanto! Se caminhares para a frente, ainda nova parede, feita de Despeitos e Impotências, tremenda, de granito, broncamente se elevará ao alto! Se caminhares, enfim, para trás, ah! ainda, uma derradeira parede, fechando tudo, fechando tudo - horrível - parede de Imbecilidade e Ignorância, te deixará num frio espasmo de terror absoluto..." 
conservadores os favelados tornavam-se um "caso de polícia"; para a esquerda eles se constituíam em massa muda e emblemática, carente de doutrinação ideológica capaz de atuar de forma decisiva na ordem capitalista" (Meihy, 1994, p. 48, 49).

Para chegar aos caminhos da construção da autoria caroliniana, desviando do ponto de vista de quem a viu como "o outro" a quem era "dada a voz" - já de antemão qualificada a um lugar fixo de enunciação - é necessário primeiramente compreender que a favela nunca foi seu horizonte discursivo exclusivo, embora seja matéria de sua escrevivência. A favela não era lugar de pertencimento para a autora. Ao contrário, esta nutria desejo perene de viver no campo e defendia tal vivência como solução coletiva possível para os moradores de favela desprezados pelos mecanismos de representação democrática e do aparato moderno capitalista em franco desenvolvimento nas décadas de 1950/1960 ${ }^{46}$.

No dia 24 de fevereiro de 1941, a Folha da Manhã imprime uma foto de Carolina Maria de Jesus junto ao jornalista Willy Aureli. Neste mesmo jornal o primeiro texto da escritora é publicado: um poema em louvor a Getúlio Vargas ${ }^{47}$ :

\author{
GETÚLIO VARGAS \\ Foi o orgulho da nossa gente. \\ É opinião brasileira \\ Que tivemos um presidente \\ Que honrou nossa bandeira. \\ Getúlio, heróico e potente, \\ Grande alma nacional, \\ Deveria ser o presidente \\ Desde o tempo de Cabral. \\ Éramos um povo inibido, \\ Apático e sem ação \\ Mas Getúlio, o destemido... \\ Nos deu um empurrão. \\ Retirou do operário a tibieza \\ Deu-lhe apoio e proteção \\ Convidou-lhe com delicadeza \\ A colaborar no progresso da Nação \\ (Jesus, 1996b, p. 135).
}

\footnotetext{
${ }^{46}$ O poema "O Colono e o Fazendeiro", sempre citado pela autora, ilustra este desejo que também era projeto.

${ }^{47}$ Não o localizamos no acervo virtual do jornal (disponível no site: http://acervo.folha.com.br/fdm/1941), mas há um poema intitulado "Getúlio Vargas" na Antologia Pessoal, embora sem afirmar com precisão, cremos ser o mesmo.
} 
Na ocasião de publicação desse poema a mídia batizou Carolina de "poetisa negra". Uma "poetisa negra" que canta no jornal os louvores do presidente que "Retirou do operário a tibieza, deu-Ihe apoio e proteção, convidou-Ihe com delicadeza, a colaborar no progresso da Nação" tem sua enunciação inicialmente inserida no contexto do Populismo brasileiro, que encontra em Getúlio Vargas grande manifestação. Vargas, Ademar de Barros - prefeito de São Paulo à época - e Janio Quadros - eleito presidente no mesmo ano que saiu Quarto de Despejo -, foram os principais populistas brasileiros (Santos, 2009, p. 85) e são figuras frequentes nas narrativas carolinianas, ao ponto de tornarem-se quase personagens de suas histórias:

19 de julho. Despertei as 7 horas com a conversa dos meus filhos. Deixei o leito, fui buscar água. [...] Assim que cheguei a Florenciana perguntou-me:

- de que partido é aquela faixa?

Li P.S.B. e respondi Partido Social Brasileiro. Passou o senhor Germano, ela perguntou novamente:

- Senhor Germano, esta faixa é de que partido?

- do Janio!

Ela rejubilou-se e começou a dizer que o Dr. Adhemar de Barros é um ladrão. [...]. Eu, e D. Maria Puerta, uma espanhola muito bôa, defendíamos o Dr. Adhemar. D. Maria disse:

- eu sempre fui Ademarista. Gosto muito dele, e de D. Lêonor.

A Florenciana perguntou:

- Ele já deu esmola a senhora?

- já, deu o Hospital das Clinicas (Jesus, 1960, p. 19).

Entretanto, independente dos qualitativos que foram atribuídos à Carolina Maria de Jesus - de "poetisa negra" a "escritora favelada" - o ideal de poeta da autora encerra uma racionalidade que, em suma, representa uma possibilidade de organização de si, de sua existência social num contexto cotidianamente atribulado. Trata-se, em última instância, de uma forma de entendimento do mundo que parece auxiliar a autora a movimentar-se melhor nele.

\footnotetext{
Vasculhei as gavêtas, procurando qualquer coisa para eu lêr. Uma vizinha, emprestou-me um romance, Escrava Isaura. Compreendi tão bem o romance que chorei com dó da escrava e agradeci a Deus, pôr não ter nascido escrava. Compreendi que naquela época os escravos, e os escravizadores eram ignorantes, tipos de homens que viam apenas o presente, e não viam o futuro porque, quem é culto não escraviza e quem é culto não aceita ser escravisado. (...) e assim foi duplicando o meu interesse pelos livros. Não mais deixei de lêr. Passei a ser uma das primeiras da classe (...) e fui ficando vaidosa, e com dó dos prêtos que não sabiam lêr. Compreendo que os que sabem lêr têm mais possibilidades para viver melhor (Meihy \& Levine, 1994, p. 175).
}

Da percepção de que os que sabem ler "tem mais possibilidades para viver melhor" à costura do ideal de poeta que a autora desenvolveu ao largo do tempo em suas narrativas, 
revela-se o lugar de relevo que a leitura como compreensão do mundo e a escrita como experiência do mundo representa para o sujeito Carolina Maria de Jesus. Experiência, em suma, de insubordinação, como nos diz Conceição Evaristo ao tratar da inscrição literária das mulheres negras:

O que levaria determinadas mulheres, nascidas e criadas em ambientes não
letrados, e quando muito, semi-alfabetizados, a romperem com a passividade da
leitura e buscarem o movimento da escrita? Talvez, estas mulheres (como eu)
tenham percebido que se o ato de ler oferece a apreensão do mundo, o de escrever
ultrapassa os limites de uma percepção de vida. (...) Em se tratando de um ato
empreendido por mulheres negras, que historicamente transitam por espaços
culturais diferenciados dos lugares ocupados pela cultura dominante, escrever
adquire um sentido de insubordinação (Evaristo, 2007, p. 20-21).

O que Carolina Maria de Jesus nomeia ideal de poeta está no âmbito da constituição de seu ethos literário, ou imagem de si no discurso. É parte fundante deste ethos a construção da imagem de si como escritora, herdeira dileta de seu avô "Sócrates Africano", maior referencial familiar da autora. 


\section{3 - A escrita ficcional: Pedaços da Fome - a experiência, a cidade e a escassez.}

Não deixo de escrever porque o escrever para mim é tão escencial devido a fusão de ideias que promonam no meu cérebro. Quando vejo uma cachoeira despreendendo água em abundância e o céu superlotado de estrelas penso tudo que da natureza é em profusão e assim são os versos que povoa o meu

cérebro.

- Carolina Maria de Jesus

A obra de Carolina Maria de Jesus, em conjunto, constitui uma morfologia da experiência marginal na modernidade, cujos eixos se concentram em duas estruturas problemáticas: a cidade e a escassez.

Desde o século XIX a literatura ocidental elegeu como temas importantes a representação da cidade e dos impactos da modernização na vida do sujeito, variando os registros ficcionais decorrentes desse tema e a problematização das implicações dele provenientes em perspectivas, por um lado, repletas de nostalgia de um universo composto por um tempo e um espaço ainda pouco afetados pela ótica da vida urbana; e por outro, a um desconforto exaltado, à sensação de isolamento e sentimento de anonimato frente às transformações do espaço.

Em geral, a cidade se opõe ao campo e as implicações de cada espaço repercutem no sujeito. No entanto, as elaborações feitas sobre o campo, bem como as que dizem respeito à cidade, devem ser pensadas, de acordo com Raymond Williams, a partir do contexto singular do qual emergem, considerando os componentes históricos, ideológicos e estéticos que norteiam cada percepção e/ou experiência (Williams, 1989, p. 11, 12). Dessa forma, em determinados contextos histórico-culturais, temos a representação do urbano e do rural e das experiências sociais atreladas a cada espaço caracterizadas ao largo das oposições dicotômicas que observam o campo como lugar da não-civilização ou do ponto onde se pode encontrar em estado de pureza a vida natural, o tempo cíclico, o sentimento de comunidade, a harmonia; elementos que a cidade dissociaria.

Para o crítico inglês, a emergência das cidades enquanto espaço a projetar a noção de futuro e de progresso é das concepções mais propagadas e internalizadas no imaginário do homem moderno. Deste ponto de vista, a cidade se configura como o "centro de realizações", 
espaço perfeito para alcançar o ápice da emancipação humana e material, onde os atributos da autonomia e individualidade do sujeito poderiam progredir.

De fato, reconhecemos na escrita de Carolina Maria de Jesus esta percepção em grau elevado: destaca-se na composição dos diários a concepção de que na metrópole tudo é passível de acontecer e a cidade torna-se uma coisa real que se sustenta na utopia, por sua vez transformada em desejo.

É em São Paulo que os pobres vão viver, é em São Paulo que os jovens vão instruirse para transformar-se nos bons brasileiros de amanhã [...] Fiquei pensando na minha família, eram todos analfabetos e não poderiam viver nas grandes cidades. E a única coisa que eu poderia fazer por eles era ter apenas dó [...] Até que enfim, eu ia conhecer a ínclita cidade de São Paulo! Eu trabalhava cantando, porque todas as pessoas que vão residir na capital do estado de São Paulo rejubilam como se fossem para o céu. [...] Quem sabe ia conseguir meios para comprar uma casinha e viver o resto dos meus dias com tranquilidade... (Jesus, 1986, p. 200-203).

A utopia da cidade revela-se ainda na noção de autonomia e individualidade do sujeito, como podemos notar nesta passagem: "Eu dava os parabéns a mim mesma, analisando a minha ascensão. Compreendi que dependia de mim mesma lutar para vencer" (Jesus, 1986, p. 197). A busca por autonomia do indivíduo é encadeada à percepção que compreende a metrópole como espaço que "sempre foi a sede da economia monetária", da "multiplicidade e concentração de troca que a fragilidade do comércio rural não teria permitido" bem como da "mais alta visão econômica do trabalho" (Simmel, 1979, p. 20). Dentro desta visão, o espaço rural e até mesmo as cidades pequenas são consideradas aquém das possibilidades emancipatórias projetadas na metrópole.

Para Walter Benjamin, o camponês sedentário, aquele que conhece as histórias e tradições de seu lugar, é quem guarda ainda a capacidade de narrar e de "intercambiar experiências" (Benjamin, 1996, p. 198). Segundo o filósofo alemão, "o primeiro indício da evolução que vai culminar na morte da narrativa é o surgimento do romance no inicio do período moderno" (Benjamin, 1996, p. 201). O livro separa o romance da narrativa ao extirpar de si a tradição oral. O romance, filho legítimo da cidade moderna, acentua, pois, a incapacidade de narrar.

A escritora Carolina Maria de Jesus, saída do campo em busca de condições de autonomia na cidade, ao contrário, narra para sobreviver ao universo citadino e retira da cidade as ferramentas para narrar, pois recolhe dos refugos da metrópole os materiais necessários para a subsistência física e para a resistência subjetiva: nos papéis e cadernos usados que encontra no lixo ela escreve suas experiências. Dentro de sua escrita, 
compartilham-se diversas narrativas, como neste exemplo, em que a narração do presente cotidiano é interrompida para contar a história de uma experiência passada. O fio entre as duas, ou o motivador da rememoração da narrativa passada, é o choro presente da filha. O conteúdo da narrativa contada é justamente o desajuste de um sujeito, vindo de um ritmo de vida completamente outro, ao espaço da cidade:

Eu estava abluindo-me para sair a uma e mêia. quando a Vera vêio dizer-me que sujou a meia... Voçê nao vae? Cachorra. Eu vou mamãe! Eu vou mamãe! Eu gosto da cidade! Lá é tão bonito! E começou a chorar. O chôro comove as maes. Então eu pensei: os índios não choram. Êles tem um proçesso. Quando a criança nasçe e quer chorar elas impedem E eles não choram mais. Dizem que é para não espantar as caças. Penso que êste buato é falso porque eu já vi um índio chorando.

Quando eu trabalhava na rua Barão de Limeira na casa de minha comadre. O Ita Hotel, estavam pintando a casa. 1948.

O nome do índio era Aristiquens Sarrilha.

Ele era pintor. Muito morôso sabia escrever com rimas. E mostrou-me os seus escritos. Eu não sou repórter mas, sempre quiz saber as raizes das coisas pergunteiIhe:

- porque dêixaste a selva?

Atraido por estas mulheres de pele alva da cor de algodão e olhos verdes da cor das fôlhas e o cabêlo ganga. Mas elas ficam muito cara para um homem. La na selva se um homem gostar de uma mulher da-lhe uma flôr ou um favo de mel. E elas ficam contentes. A civilizadas o homem tem que lhes dar dinheiro casaco de pele e pedras preciosas.

E como foi que você ficou sabendo que existia mulheres de cabelos gangá que são as loiras?

Um dia eu estava andando pela estrada achei uma revista E eu vi os retratos das mulheres de bôca pintada da côr de urucum. E as unhas vermêlhas da côr de viludo.

E eu desejêi possuir uma para mim. Pensei que elas havia de ser mais ternas do que as índias.

- e voçê já conseguiu uma?

- já. Mas deçepcionei-me.

A loira que eu dei o meu amplexo tinha o cheiro de jarátataca percibi que êle refiria ao mau halito.

- onde a vida é melhor, aqui ou na selva?

Na selva. Porque não passa fome.

Pensei: se algum dia eu passar fome vou ressidir na selva. Naquela época eu achei o índio estupido. Mas agora, Ihe considero um proféta.

E êle descrevia a bêleza da selva. La o superior respêita e considera o inferior. Eu não compreendo voces que se diz civilisados só porque sabe ler. Aqui o apôio do homem é o dinheiro.

E você acha que o dinheiro sêja desnecessário num paiz?

O dinheiro é o causadôr da origem de classe. O rico pensa que é potente. E o pobre, impotente. E extinguindo o dinheiro ha de vir uma classe única. Nos temos so um sol para benéficiar o mundo. Não existe sôis. So existe um sol.

E quando existir so uma classe o homem há de sentir-se melhor entre os homens.

E o índio retirou-se dizendo: voçê não me compreende. Voçê é civilisada.

Esqueci de perguntar ao índio como foi que ele aprendeu a ler.

A tarde ele foi despedido porque era moroso no trabalho quando saiu despediu-se de mim e disse-me, que não tinha sorte. - E chorou. E porisso que eu disse: que já vi um índio chorar.

Lavei a meia da Vera e calcei molhada. Saímos, tomamos o bonde e cheguei nas Folhas (Citado por Perpétua, 2000, p. 351, 352). 
Para Williams, a partir "de uma vivência das cidades nasceu uma vivência do futuro", pois é na experiência do espaço urbano que o sujeito moderno potencializa sua inclinação para transformar a realidade. Nesse sentido, é calcado no alicerce histórico da estrutura metropolitana que este sujeito planeia seu futuro e o de sua comunidade.

\begin{abstract}
Numa crise da experiência metropolitana, as histórias sobre o futuro sofreram mudança qualitativa. Havia modelos tradicionais para esse tipo de projeção. Em todas as literaturas conhecidas, sempre houve uma terra além da morte: um paraíso ou um inferno. Nos séculos de explorações e viagens, novas sociedades foram descobertas, vistas como promessas ou como alertas, em novas terras: em muitos casos, ilhas; muitas vezes, a ilha feliz, ela própria um elemento que dá forma ao mito. Mas, dentro da experiência metropolitana, esses modelos, ainda que muito utilizados, terminaram sendo transformados. O homem não atingia seu destino, nem descobria seu lugar ditoso: ele descobria, no orgulho ou no erro, sua própria capacidade de realizar uma transformação coletiva de si próprio e de seu mundo (Williams, 1989, p.366).
\end{abstract}

Se a cidade é o espaço privilegiado para a racionalização da sociedade, na literatura a perspectiva urbana não se limita apenas à temática, mas expande-se enquanto visão de mundo, formalizando maneiras próprias de expressão e linguagem que traduzem o urbano para além da descrição de espaços citadinos, mas, sobretudo, no engendramento de modos de agir, de pensar e de se relacionar com os valores que a cidade propaga, o que, em última análise, constitui-se como princípio estruturante das formas simbólicas. Deste processo, emergem novas formas de expressão e novos gêneros literários, como o a narrativa policial, a crônica, o conto e o romance.

A consolidação do gênero romance na Europa está intrinsecamente ligada ao aprofundamento das formas de vida urbanas e burguesas, refletindo formas novas de narrar a experiência e as relações entre o sujeito e o espaço. Com efeito, o gênero literário romance "não inaugura somente uma morfologia mas também uma representação de um modo de viver, um gênero que veio preencher um desejo, um vazio, uma mitologia que antes era exercida por outros gêneros" (Fernandes \& Lima, 2000, p. 25). Da mesma maneira, no Brasil, a escrita de autores como Aluísio Azevedo, Machado de Assis, Lima Barreto e João do Rio vinculam-se ao imaginário urbano da metrópole-modelo representada pelo Rio de Janeiro: "sede do governo, centro cultural, maior porto, maior cidade e cartão de visita do país, atraindo tanto estrangeiros quanto nacionais" (Sevcenko, 1998, p. 523). A cidade do Rio de Janeiro nesse momento, "corte" e também capital federal da República, desenvolve-se a partir de um cosmopolitismo tanto político como literário, e não é por acaso que Machado de 
Assis, maior romancista de nossas letras, situa seus romances e conflitos neste espaço geográfico.

De lá para cá, o caráter urbano da literatura brasileira perpassa tempos históricos, marcando o Modernismo, onde surge como problematização formal das mudanças de um Brasil rural para outro, industrial, destacando São Paulo como espaço símbolo do desejo por desenvolvimento. Encenando os romances dos anos 30-40, em que se salienta um "novo empenho" dos intelectuais frente aos impasses e contradições da formação cultural nacional - dispostas nos polos campo e cidade, interior e centro, atraso e modernidade. De acordo com Antonio Candido, o "romance de 30" foi uma das formas de expressão através da qual os intelectuais se propuseram a "resolver" tais contradições, dado o momento em que o romance se dedicou a problematizar a integração das classes sociais à margem do processo de modernização à vida moderna ${ }^{48}$.

Entretanto, o ideário moderno, além de utopias de autonomia e liberdade, gestou também os seus contrários, pois a manutenção da ordem social norteada pela busca do progresso e a própria organização do espaço da cidade resulta e alimenta um estado contraditório repleto de dilemas. Dai a complexidade que gira em torno da marginalização social, do sentimento de não pertencimento, da visão fragmentária e desagregação da identidade do sujeito e do espaço onde transita e a dificuldade em manter laços: elementos frequentes na reflexão sobre a experiência urbana moderna. Ainda mais fortemente em contextos sócio-históricos de modernidade excludente, conservadora ou tardia - como é o caso do Brasil - os projetos de "transformação coletiva de si próprio e de seu mundo" esbarram na crise de manutenção dos mais diversos projetos geridos pela modernidade, resultando em desigualdades sociais que implicam na observação de que a autonomia e a liberdade não estão à disposição de todos.

Este é o segundo ponto de relevo da estrutura literária caroliniana: a escassez material e a falta de cidadania para muitos dos que tomam parte da experiência urbana moderna acaba por entrincheirar-se na própria constituição dos sujeitos:

\footnotetext{
48 "Os romancistas da geração de Trinta, de certo modo, inauguraram o romance brasileiro, porque tentaram resolver a grande contradição que caracteriza a nossa cultura, a saber, a oposição entre as estruturas civilizadas do litoral e as camadas humanas que povoam o interior - entendendo-se por litoral e interior menos as regiões geograficamente correspondentes do que tipos de existência, os padrões de cultura comumente subtendidos em tais designações" (Candido, 1992, p. 45).
} 
Nós somos pobres, viemos para as margens do rio. As margens do rio são os lugares do lixo e dos marginais. Gente da favela é considerado marginais. Não mais se vê os côrvos voando as margens dos rios, perto dos lixos. Os homens desempregados substituíram os corvos (Jesus, 1960, p. 55).

Passou um senhor, parou e nos olhou. E disse perceptível: será que êste povo é dêste mundo? Eu achei graça e respondi: nós somos feios e mal vestidos, mas somos dêste mundo. Passei o olhar naquele povo para ver se apresentava aspecto humano ou aspecto de fantasma (Jesus, 1960, p. 140).

A experiência do sujeito cuja relação com o espaço dá-se na transfiguração do modo de vida rural para o urbano é o tema central do livro Pedaços da Fome, romance de Carolina Maria de Jesus publicado no mesmo ano de Malaguetas, Perus e Bacanaço (1963), primeiro livro de João Antônio, no qual a linguagem das ruas alcança estatuto ficcional elaborado.

A escrita ficcional possuía, para a autora, um valor diferente dos diários. Era pelo romance e pela poesia que Carolina Maria de Jesus gostaria de ser conhecida enquanto escritora, em detrimento da fama e popularidade angariadas com a publicação dos seus textos autobiográficos. A diferença de valor não se dá apenas na ideia dicotômica de que a "verdade" diz respeito à autobiografia e o "fingimento" se diz parte da ficção, afinal, como Pessoa já nos ensinou, o poeta "finge tão completamente que chega a fingir que é dor a dor que deveras sente". Observaremos na análise do romance que aspectos biográficos da autora tomam parte da elaboração ficcional que estrutura o enredo e algumas personagens.

Se a forma romance reflete novas maneiras de articular a experiência entre sujeito e espaço, na escrita de Pedaços da Fome (1963) podemos ler o perfeito enlace de dois polos centrais do universo caroliniano: a cidade e a escassez, que norteiam a própria estrutura da obra, configurando a formalização problemática de uma experiência social repleta de tensões. Composto nos tempos em que morava na favela do Canindé, "burilado e refundido pela própria autora no final de 1962 e entregues os originais à editora no início de 1963" - de acordo com a "nota explicativa" que acompanha o livro. O romance saiu pela Editora Aquila e a própria Carolina financiou a edição com os lucros que recebera de Quarto de despejo.

A apresentação do romance, assinada por Eduardo de Oliveira, destaca a forte relação que Carolina Maria de Jesus nutria com a escrita, considerando-a como segunda natureza da autora: "O mister de escrever, de registrar pequeninos acontecimentos cotidianos, para a autora é algo tão vital, tão íntimo, tão organicamente vinculado à sua condição de ente pensante, que este ato já se transformou, em seu temperamento irriquieto (sic) e inconformado, numa segunda natureza" (Oliveira, 1963, p. 12). 
Oliveira identifica automaticamente a voz narrativa com a voz autoral a partir da qual Carolina Maria de Jesus era lida: a da "escritora favelada" porta-voz dos que não tem voz, mantendo o papel homogêneo da crítica quanto à discursividade caroliniana:

O leitor há de surpreender-se ao passar os olhos por estas páginas úmidas de lágrimas, ao ouvir saltar aqui e ali, o grito surdo, impotente, patético mesmo de Carolina Maria de Jesus, como a voz clamante do deserto, sofrendo por milhares de sêres anônimos, cruelmente agredidos e apedrejados pelos "Pedaços da Fome" (Oliveira, 1963, p. 13).

De fato, ao destacar a solidão da voz isolada "clamante do deserto" que sofre em nome daqueles seres anônimos sujeitados pela fome, Oliveira junta-se ao conjunto dos leitores críticos que compreenderam Carolina Maria de Jesus do ponto de vista da representação coletiva. Entretanto, embora a voz autoral caroliniana esteja além da narração sobre a miséria dos oprimidos, há grandes aproximações entre o enredo do romance e a experiência da autora, conforme ela a constrói nos diários.

A maior destas é a trajetória trágica de Maria Clara - protagonista da história - do interior para a cidade, passando por cortiços e terminando na favela - mesmo destino da autora. Pedaços da Fome é um folhetim que narra o roteiro de Maria Clara da riqueza à miséria. Filha de um poderoso coronel do interior paulista, ela se apaixona por Paulo, personagem dissimulado que traz em seu nome - (São) Paulo - a marca da grande cidade. Paulo se apresenta a partir de uma ilusão que encanta a mocinha: diz ser um bem sucedido dentista. Mas na realidade não tem nenhuma formação e nem perspectivas de ter, é pobre e mora de favor num pequeno quarto nos fundos de um cortiço. A razão da mentira é o desejo de aproximar-se de Maria Clara, que até encontrá-lo "não conhecia as lutas da existência", pois "para ela as palavras sofrimento eram abstratas" (Jesus, 1963, p. 29).

O campo e a cidade são instâncias opostas no texto: no primeiro, reina um encadeamento ordenado das coisas, estruturado no poder personalizado sob o jugo do coronelismo. Já no núcleo urbano ganham relevo as condições precárias de subsistência no espaço citadino, focalizando principalmente a estrutura dos cortiços e da favela. O enredo do romance é centrado em três personagens principais: Paulo, Maria Clara e o Coronel Pedro Fagundes, pai da mocinha, possuidor de grande poder de mando e de diversas qualidades morais:

Homem de quarenta e cinco anos, enérgico e lépido. Era homem de ação. Não conhecia a tibieza, o que iniciava concluía. (...) Não havia dúvida, nascera sôbre o domínio de uma boa estrêla, pois até essa idade não encontrava impecilhos na vida, tudo era amplo, igual ao espaço, via tôdas as aspirações realizadas, às vezes ficava 
pensando: "consigo tudo que almejo, tenho a impressão que a felicidade é minha madrinha e que me protege com seu manto". Sabia-se benquisto por todos, mesmo assim, vez ou outra, meditava profundamente fazendo uma revisão de sua vida. Era íntegro, e não prevalecia de sua posição social em proveito próprio; não apreciava as polêmicas porque arrefecem as amizades; não discutia com ninguém e, tãopouco, desconfiava dos que o rodeavam, pois a desconfiança gera inquietação interior. Pagava bem os que o serviam, pois quem é correto para pagar o que deve não promove atritos. Elogiava a todos que conhecia, por isso pensava que não tinha inimigos (Jesus, 1963, p. 15, 16).

A experiência no campo e na cidade engendram características diferentes na visão de mundo dos personagens: durante o período em que viveu no interior, sob a proteção de seus ricos pais, a protagonista do romance agia e pensava a partir de determinadas inclinações de classe, relacionando-se de modo petulante e autoritário com os que a rodeavam. Somente quando afasta-se desse núcleo a personagem transforma seu modo de agir e pensar, ao declinar da posição de rica proprietária para o da miséria urbana.

Maria Clara foge com Paulo da pequena cidade dominada por seu pai, quando chegam a São Paulo ela descobre que ele havia mentido e que na verdade é pobre, os dois vão morar num quarto de cortiço na periferia da cidade e o roteiro se estende em privações e desunião do casal, pois Paulo não oferece nada do ideal de matrimônio que a jovem ansiava. $O$ personagem, no entanto, torna-se complexo, pois não recebe nenhuma vantagem econômica de sua manobra para conquistar a relação com a jovem milionária: ele não se casa por dinheiro, mas por amor, e a leva para o seu núcleo social. O romance, nesse sentido, adquire uma espécie de tom didático: trata-se de ensinar uma jovem rica e prepotente a tornar-se mais humana - dádiva conquistada apenas através da experiência limite da pobreza e da falta. A decadência da heroína é fruto da desobediência a seus pais, que desaprovavam a união com Paulo; e também é resultado do descontrole emocional da jovem, que foge com ele um dia depois de tê-lo conhecido. Este é um tema recorrente em Quarto de despejo: Carolina Maria de Jesus diversas vezes relaciona o regramento da vida amorosa à sua subsistência e a dos seus filhos, pois, segundo ela, os homens tendem a se aproximar unicamente para beneficiarem-se de seu trabalho e lucro. Observa-se em Pedaços da Fome um tipo de "vingança" do narrador para com a personagem, mostrando-lhe a complexidade da situação social fruto da pauperização, decorrente das condições desiguais de distribuição de renda e do egoísmo dos ricos, e fazendo-a compreender as consequências das desigualdades na própria pele:

Maria Clara ergueu os olhos em direção a janela e disse, entre murmúrios e soluços:

- invejo as nuvens que seguem lentamente, livre de preceptores; e prosseguiu 
lamentando: - Eu não conhecia a mania dos ricos porque quando somos ricos não percebemos o quanto a nossa exigência escravisa uma pessoa. Mas eu também obriguei muitos pobres a curvar-se aos meus pés. [...] O meu casamento com você é uma expiação daquelas faltas. Dizem que o que se faz paga-se. Agora eu estou acreditando nisso. Os ricos pensam que os pobres desconhecem os sentimentos; que são insensíveis. Aos ricos nunca fazer advertências porque êles é que predominam. Agora que sou pobre é que tenho dó dos pobres. Porque compreendo o seu sofrimento. Quantos pobres hão se estar ressentidos comigo. [...] E entre triste e arrependida ajuntou: - Se eu voltar a ser rica um dia, juro que hei de ser filantrópica. Eu nunca dei esmola a um pobre. O meu dinheiro era destinado ao luxo. Queria ser bonita, atraente e arranjar um namorado (Jesus, 1963, p. 115, 116).

A experiência da pobreza funciona como redenção da moça rica por um lado e como catarse da narradora por outro. Ao final do roteiro de agruras, Maria Clara retorna ao convívio de sua classe de origem através do resgate de seu pai, que passa os anos em que ela esteve desaparecida numa tenaz e incessante busca pela filha. É a experiência do urbano, portanto, que amplia a capacidade de autonomia da personagem, pois para sobreviver aos infortúnios da pobreza ela torna-se, pela primeira vez, independente: garante o seu sustento, dos filhos e do marido, toma decisões e muda o próprio rumo, modificando sua maneira de compreender o mundo. Durante o período em que vivera no campo, suas ações, ao contrário, eram completamente submetidas à estrutura familiar e ao modelo representado pelo pai.

Há no romance, marcas de convergência com o ponto de vista da narradora da escrita diarística. Reconhecemos, lendo Pedaços da Fome, elementos que Carolina Maria de Jesus traz em Quarto de Despejo e Diário de Bitita, por exemplo, a compreensão de São Paulo como a cidade símbolo do progresso e utopia máxima do desenvolvimento:

Ouvi dizer que a mulher que se casar com um homem paulista não sofre, está amparada na vida, que o paulista é atilado. É nobre e sensato. Que são homens decentes. Que prezam a sua dignidade. Que tem noção de deveres. Que são previdentes aprendendo um ofício. Quem nasce em São Paulo tem possibilidades de aprender um ofício, porque São Paulo é a Capital da indústria. E todos encontram trabalho. Quem nasce em São Paulo nasce num escrínio de ouro por ser bom elemento (Jesus, 1963, p. 35).

Quem nasce em São Paulo por fôrça tem que ser um homem culto porque é uma cidade industrial. É um núcleo em que as pessoas vão crescendo e emancipando-se (Jesus, 1963, p. 45).

A fome também é bastante presente, reafirmando a revolta que Carolina Maria de Jesus nutria com o estado de coisas que a mantinha como estrutura de "escravidão atual": "A fome é um monstro terrível que destrói nações" (Jesus, 1963, p. 123).

Na voz da personagem Maria Clara ouvimos expressões comuns em Quarto de Despejo, como a indignação com as condições precárias de moradia: “Um quarto que não se 
pode usar nem para quarto de despejo" (Jesus, 1963, p. 119). E a ânsia por independência e autonomia: "Maria Clara pensou: - Como é horrível as sugestões alheias. Ela sabia pensar e decidir seus projetos" (Jesus, 1963, p. 118). Destaca-se também a ideologia do progresso, do trabalhismo paulista, presentes na narrativa caroliniana como um todo:

Se o senhor não era um homem arrojado porque casou-se? E quem sofre são os teus filhos. Esta classe de homens apáticos, morosos, indolentes por fôrça há de extinguir-se porque com o decorrer dos tempos o mundo vai evoluir-se. E todos terão de trabalhar porque o homem vadio não tem valor (Jesus, 1963, p. 174).

Pedaços da Fome também pode ser articulado com a biografia da autora de outra forma: o romance relaciona a experiência da leitora Carolina, estabelecendo alguns níveis de interdiscursividade com Escrava Isaura, livro de Bernardo Guimarães que marcou a escritora. Em muitas passagens Maria Clara se autodenomina "escrava", do marido: "- Sabe Paulo, tem hora que você repugna-me. Oh! Meu Deus! Isto não é vida! Você quer transformar-me em escrava" (Jesus, 1963, p. 143); da tia rica de Paulo:

Maria Clara começou a sentir os extertores do parto: era uma hora da manhã. O Paulo foi despertar a Dona Maura. Êle queria procurar a tia Raquel. Maria Clara recusou: - Não. Não. Eu prefiro a dona Maura. É mais compreensível. E até aqui é sempre ela que tem nos auxiliado. Ela nunca recusou-me um favor. A tua tia não veio ao mundo para favorecer ninguém. E se ela favorecer-me há de querer transformar-me em escrava. Ela já tem a alma de escravocrata (Jesus, 1963, p. 136).

E da pobreza:

Maria Clara continuava agora em um tom ainda mais severo: - Chega a vida atribulada que você proporciona-me. Já estou senil, combalida. Você diz que tem dó de mim. Não creio. Você não tem consciência. Lá na vila você era pacato porque temia a dona Maura. Aqui [na favela] eu não tenho ninguém. Não tenho defensor. Lá você me auxiliava nos serviços domésticos. Aqui deixa tudo por minha conta. Tudo aos meus cuidados. Quando penetro dentro desse barracão não sei onde iniciar, a desordem é tamanha que me sinto vencida. Você disse-me que é meu escravo... mas a escrava sou eu. Eu não sabia andar calçada com tamancos; aprendi. Eu não comia pão amanhecido. Atualmente como pão duro. Tenho estômago de avestruz (Jesus, 1963, p. 189, colchetes meus).

No enredo de Pedaços da Fome temos uma jovem branca, rica e esnobe que como consequência do casamento com Paulo autodenomina-se escrava urbana da pobreza, dos filhos e do marido. Este a reposiciona do pedestal de onde ela nascera rebaixando-a a sua classe social despossuída. Ao decair socialmente a protagonista revê os seus valores e preconceitos sociais e perde a petulância, tornando-se generosa, humilde e, principalmente, sujeito de suas ações. Passada a experiência da miséria, ela retorna à riqueza, junto ao pai que a resgata do estado de privações. O enredo de Bernardo Guimarães, por sua vez, apresenta uma escrava cheia de virtudes e branca - branca, para sensibilizar e promover 
maior identificação junto aos leitores da época - que devido ao casamento com o homem que ama escapa da condição de escrava e torna-se livre. A relação entre os dois romances dáse pela inversão: no canônico romance romântico o desenrolar da história faz justiça a uma jovem repleta de qualidades morais, embora escrava, que é salva pelo casamento por amor. Já no romance pouco conhecido de Carolina Maria de Jesus temos o desenvolvimento do enredo pautado na correção moral da jovem Maria Clara, cujo casamento, também por amor, a leva a experimentar um universo social oposto ao seu, tornando-a virtuosa pelo sofrimento ocasionado.

A leitura acumulativa dos diários potencializa a análise crítica deste romance, pois deixa ver o conteúdo da trajetória discursiva caroliniana, cujo nervo central é a cidade, ou mais que isso, a degradação urbana. A pobreza não é apenas tema, enredo ou cenário, mas estrutura a própria dicção das obras, funcionando como uma gramática das relações urbanas.

De posse das ações da personagem, a narradora pode reelaborar a experiência da própria autora: dar sentido ao destino de restrições vivenciado na metrópole, que dera à Carolina a chance de ser dona do próprio enredo, fora do âmbito das chancelas familiares e sociais que molduravam o quadro coletivo das pequenas cidades por onde passou; essa mesma metrópole - cujo nome batiza o personagem que encanta, ilude e faz sofrer a protagonista - tornou-se elemento fundamental do exercício de escrever (-se) que possibilitou à escritora furar as camadas de silenciamento e opressão socialmente impostas a ela - e historicamente impostas às mulheres negras - e engendrar espaços de autonomia e empoderamento. 


\section{A "ESCRITA DE SI"}

\section{1 - Casa de alvenaria - diário de uma ex-favelada}

Agora eu falo e sou ouvida. Não sou mais a negra suja da favela.

- Carolina Maria de Jesus.

Segundo Philippe Lejeune, "Escrever e publicar a narrativa da própria vida foi por muito tempo, e ainda continua sendo, em grande medida, um privilégio reservado aos membros das classes dominantes. O "silêncio" das outras classes parece totalmente natural: a autobiografia não faz parte da cultura dos pobres" (Lejeune, 2008, p. 113). De fato, a publicação dos diários de Carolina estabelece uma diferença fulcral ante o sujeito tradicional ${ }^{49}$ do discurso autobiográfico, em geral representado em "biografias de figuras notáveis, de heróis fantásticos" (Levine \& Meihy, 1994, p. 17).

Como a epígrafe acima nitidamente revela, para Carolina Maria de Jesus a condição de morar na favela estava diretamente ligada ao silenciamento imposto sobre sua voz: ser moradora de favela significava objetivamente não ser ouvida. Sob sua ótica, o acesso às partes da cidade onde os discursos pareciam circular sem pressupostos de origem garantiria a conquista ao direito de falar e ser ouvida enquanto sujeito Carolina Maria de Jesus e não apenas como a "negra suja da favela" - objeto das desigualdades raciais e de classe. No entanto, o desenrolar da trajetória da escritora, impresso no Diário de uma ex-favelada, mostrou que muitas fronteiras ainda se ergueriam. De fato, a palavra de Carolina ecoava em muitos lugares do mundo, porém, a saída da condição de "negra suja da favela" impôs sobre ela um novo silenciamento: deixava de ser favelada, mas por ser mulher negra

\footnotetext{
${ }^{49}$ Por exemplo, o Diário intimo de Couto Magalhães (1837-1898) escrito antes do inicio do século XX. Membro da elite do fim do período imperial governou as províncias do Pará, Goiás e Mato grosso durante a década de 1860 e foi presidente da província de São Paulo em 1888. Dedicou-se também à literatura, publicando $O$ selvagem (1876) onde expõe suas concepções acerca do processo de "civilização" dos índios. Escrito enquanto morava na Inglaterra, no diário medita sobre máximas de Horácio, faz anotações meticulosas acerca do funcionamento de seu corpo além de registrar em códigos sonhos homoeróticos que lhe ocorriam. Joaquim Nabuco (1849-1910), autor de O abolicionismo (1883), também mantinha um diário que foi publicado em dois volumes, o primeiro referente ao período de 1873 a 1888 e o segundo cobrindo os anos de 1889 a 1910, ano de seu falecimento. Menos que notas íntimas, as páginas trazem impressões de leituras, reflexões sociológicas, anexos de recortes de jornal.
} 
semialfabetizada, o fato de passar a integrar os circuitos de poder e visibilidade midiática incomodava o universo que a tinha como ser exótico: "Não levo nenhuma ilusão/ porque a escritora favelada/ foi rosa despetalada" (Jesus, 1996a, p. 152).

\section{QUARTO DE DESPEJO}

Quando infiltrei na literatura sonhava so com a ventura

Minhalma estava chêia de hianto

Eu não previa o pranto.

Ao publicar o quarto de despejo

Concretisava assim o meu desejo.

Que vida. Que alegria.

E agora... Casa de Alvenaria.

Outro livro que vae circular

As tristêsas vão duplicar.

Os que pedem para eu auxiliar

A concretizar os teus desejos

penso: eu devia publicar...

- so o 'quarto de despejo'.

No inicio vêio a adimiração

O meu nome circulou a Nação.

Surgiu uma escritora favelada.

Chama: Carolina Maria de Jesus.

E as obras que ela produs

Dêixou a humanidade habismada

No inicio eu fiquei confusa.

pareçe que estava oclusa

Num estôjo de marfim.

Eu era solicitada

Era bajulada.

Como um querubim.

Depôis começaram a me invejar.

Diziam: você, deve dar

os teus bens, para um assilo

Os que assim me falava

Não pensava

Nos meus filhos.

As damas da alta sociedade.

Dizia: praticae a caridade.

Dando aos pobres agasalhos.

Mas o dinheiro da alta sociedade

Não é destinado a caridade

É para os prados, e os baralhos

E assim, eu fui desiludindo

O meu ideal foi regridindo

igual um côrpo envelheçendo.

Fui enrrugando, enrrugando..

petalas de rosa, murchando, murchando

E... estou morrendo! 


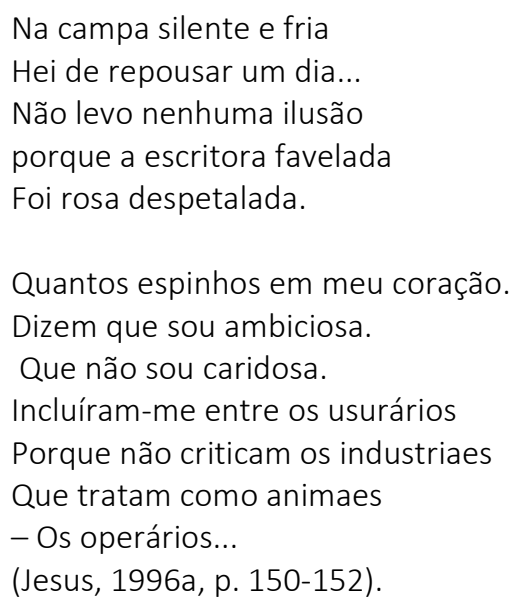

O poema transcrito acima, retrospectivo como mostra o título, está publicado em Meu estranho diário (1996), livro organizado por José Carlos Sebe Bom Meihy e Robert Levine a partir dos manuscritos de Carolina Maria de Jesus que permaneciam inéditos. O poema "Quarto de despejo" está na parte dos manuscritos de Casa de Alvenaria - diário de uma exfavelada (Jesus, 1996a, p. 150, 151), segundo livro publicado da autora.

A narratividade permeada de índices autobiográficos do poema permite que se depreenda a reflexão da autora acerca de seu itinerário pela Literatura, itinerário inscrito, logo no primeiro verso, com a deflagração da sua condição de "infiltrada". Infiltrar, no sentido de dicionário, diz respeito a algo que se faz entrar ou penetrar, como através de um filtro. Em sua forma substantiva - infiltração - denomina a "passagem de um líquido através dos interstícios" (Aurélio). Uma infiltração inesperada pode corroer as paredes de um edifício, do literário, por exemplo.

A imagem de si como uma "infiltrada" sugere que a autora estava consciente de sua própria localização face ao universo literário - que envolve as esferas de produção, circulação, valoração e legitimação de textos. Todavia, realizada a infiltração, águas de amargura escorrem-Ihe dos olhos, contraditoriamente motivadas pela publicação do segundo livro, pois este, diferente do primeiro que representava a concretização do desejo de ser escritora, trouxera à Carolina tristezas duplicadas:

\footnotetext{
Minhalma estava chêia de hianto Eu não previa o pranto.

Ao publicar o quarto de despejo

Concretisava assim o meu desejo.

Que vida. Que alegria.

E agora... Casa de Alvenaria.

Outro livro que vae circular

As tristêsas vão duplicar.
} 
A realização do desejo de ver o seu nome na capa de um livro é narrado por Carolina Maria de Jesus como algo que Ihe trouxera imensa alegria. No entanto, esse sentimento dera lugar ao seu contrário com a publicação do segundo diário, Casa de Alvenaria (1961). O diário de uma ex-favelada veio a público um pouco mais de um ano depois do primeiro, em novembro de 1961, pela mesma casa editorial, a Francisco Alves, e através do mesmo editor, o jornalista Audálio Dantas. Entretanto, a recepção do público nacional e internacional ${ }^{50}$ a este livro foi bem menor do que àquela da estreia da autora: vendeu três mil exemplares de uma tiragem inicial de dez mil. Esse momento marca o início do ponto de inflexão na trajetória de visibilidade que Quarto de despejo ocasionou na vida de Carolina Maria de Jesus. De fato, a publicação de suas narrativas, como um paradoxo do desejo de ver seu nome estampado na capa dos livros, preocupava Carolina. Em Casa de Alvenaria, ela narra a tensão que a publicação eminente de Quarto de Despejo Ihe ocasionava:

16 de julho... estava preparando-me para fazer arroz com lentilha quando Vera disse:

- Mamãe, olha o Audálio e o Paulo!

Ouvi a voz do reporter e perpassei o olhar pelo barracão. Saí para o quintal e cumprimentei o reporter e o escritor Paulo Dantas. Êle disse-me que o livro sai dia 16 de agosto. Que susto que eu levei! Eu sei que vou angariar inimigos, porque ninguém está habituado com esse tipo de literatura. Seja o que Deus quiser. Eu escrevi a realidade porque eu pensava que o reporter não ia publicar. O reporter fotografou-me e disse-me que estava esperando o senhor Cyro Del Nero, que vai fazer os desenhos do livro (Jesus, 1961, p. 30).

Mas a diferença é que Casa de Alvenaria narra as experiências da autora no seu convívio com a elite de São Paulo, seus novos vizinhos do bairro nobre de Santana onde ela passou a residir com os filhos depois do sucesso de vendas do primeiro livro. O deslocamento do ponto de vista de classe - daquela que a lê - dentro do itinerário que Carolina constrói no poema, torna-se motivo para sua derrocada literária. Leiamos novamente no poema:

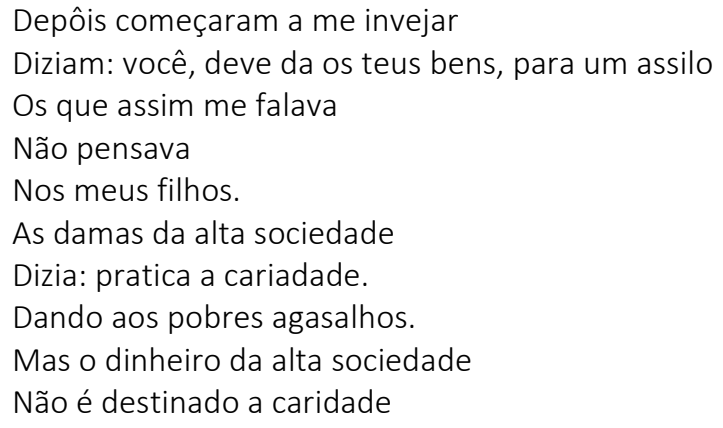

${ }^{50}$ Casa de Alvenaria foi publicado na Argentina em 1963, na França em 1964, na Alemanha ocidental em 1984 e nos Estados Unidos em 1997. 
É para os prados, e os baralhos

E assim, eu fui desiludindo

O meu ideal foi regridindo.

Na apresentação de Audálio Dantas para Casa de Alvenaria, intitulada "História de uma ascensão social", faz-se a comparação:

Como no quarto de despejo, ela continuou a escrever o seu diário, a fazer retrato. Só que o retrato da gente de alvenaria tem algumas distorções, é assim como um painel com pontos de perfeita nitidez e áreas esfumaçadas, nebulosas. Mas Casa de Alvenaria é um retrato. Feito com as contradições da retratista e, sobretudo, com as contradições dos retratados. Nem sempre a revelação que Carolina nos faz de certas criaturas é perfeita, mas, no caso, a responsabilidade não Ihe cabe. Ela procurou enfocar, com aquele seu notável senso de observação, mas não conseguiu a necessária nitidez, simplesmente porque na favela, ponto bem nítido e definido da miséria, um Orlando Lopes explorador da luz e da água não passa de um Orlando Lopes explorador da luz e da água, enquanto aqui fora os homens costumam usar muitas faces. (...) A gente da alvenaria contribuía, assim, para as contradições do retrato que Carolina fazia, com olhos de favelada, da sala de visitas. A sua capacidade de observação, aliada à sua capacidade de concluir, serviu, porém, para que apanhasse no meio desta nossa feira de vaidades aspectos bastante significativos, nem sempre observados por nós. Por exemplo, os compromissos dos que escrevem, quase sempre tolhidos em sua liberdade pelo jôgo infernal de interesses. Aqui em nosso meio, ela começou a temer também: Não estou tranquila com a ideia de escrever o meu diário de vida atual. Escrever contra os ricos. Êles são poderosos e podem destruir-me (Dantas, 1961, s/p, ênfases do original).

Nota-se que o prefácio do editor Audálio Dantas sustenta um ponto de vista de acordo com o qual o mundo é cindido em dois polos, assim como também era bipolar a topografia social que Carolina Maria de Jesus estabelece para a cidade: "Eu classifico São Paulo assim: o Palacio, é a sala de visita. A Prefeitura é a sala de jantar e a cidade é o jardim. E a favela é o quintal onde jogam os lixos" (Jesus, 1960, p. 33).

Para Dantas, os que residem na "sala de visitas" da cidade são sujeitos complexos, que usam máscaras e tem muitas faces, o que exige uma espécie de justificativa do editor para o leitor, pois neste diário, diferente do primeiro, não se poderia esperar que Carolina retratasse fielmente uma realidade cujos códigos ela não conhecia: "Nem sempre a revelação que Carolina nos faz de certas criaturas é perfeita, mas, no caso, a responsabilidade não lhe cabe". A diferença de tom em relação ao prefácio de Quarto de despejo é evidente: enquanto no primeiro livro a voz de Carolina aparece potencializada como voz de representação coletiva da massa sem voz favelada, no segundo afirma-se e justifica-se sua incapacidade de "necessária nitidez" ante um mundo formado por sujeitos difíceis de serem "retratados" por uma escritora com "olhos de favelada". Já os moradores da favela, "ponto bem nítido e definido da miséria", são figuras planas, sem profundidade, "um Orlando Lopes não passa de 
um explorador da luz e da água" e nada mais, não é, portanto, um sujeito, e sim um mero elemento componente da narração da miséria cotidiana.

Na finalização do prefácio o editor faz uma clara recomendação para que Carolina Maria de Jesus conserve-se em seu lugar:

\begin{abstract}
Finalmente, uma palavrinha a Carolina, revolucionária que saiu do monturo e veio para o meio da gente de alvenaria: você contribuiu poderosamente para a gente ver melhor a desarrumação do Quarto de Despejo. Agora você está na sala de visitas e continua a contribuir com êste nôvo livro, com o qual você pode dar por encerrada a sua missão. Conserve aquela humildade, ou melhor, recupere aquela humildade que você perdeu um pouco - não por sua culpa - no deslumbramento das luzes da cidade. Guarde aquelas "poesias", aquêles "contos" e aquêles "romances" que você escreveu. A verdade que você gritou é muito forte, mais forte do que você imagina, Carolina., ex-favelada do Canindé, minha irmã lá e minha irmã aqui (Dantas, 1961, s/n. Ênfase minha).
\end{abstract}

A publicação de Quarto de Despejo lança Carolina Maria de Jesus diretamente no mundo dos brancos, seguindo Florestan Fernandes. É neste mundo que ela escreve Casa de Alvenaria e é este mundo que a recusa.

8 de dezembro. Hoje é feriado. Não vou sair de casa. Não estou escrevendo o diário com receio de citar as confusões do povo da sala de visitas. Êles são ambiciosos e comentam com uma dose de despeito:

- A Carolina está rica (Jesus, 1961, p. 101).

O diário, para Lejeune, se define em primeiro lugar como uma "escrita quotidiana: uma série de vestígios datados" (Lejeune, 2008, p. 259. Ênfase do original). Isto é, a data é sua base e a autenticidade do momento sua essência: "quando soa a meia-noite, não posso mais fazer alterações. Se o fizer, abandono o diário para cair na autobiografia" (Lejeune, 2008, p. 259). Com razão, o tempo é o grande senhor das escritas de si, pois nelas se constitui um eixo triplo formado pelas instâncias memória-história-temporalidade, em que a maneira com que se lida com o tempo faz-se ecoar diretamente na forma e na tessitura da palavra: do diário, cuja rememoração do dia-a-dia é quase instantânea, passando pela autobiografia, que narra memórias do passado distante; do testemunho literário construído como testemunho da história; à autoficção, onde os tempos são simultâneos e não os acontecimentos no tempo.

A narrativa do diário Casa de Alvenaria começa quatro meses antes da estreia de Quarto de despejo, ocorrida no dia 19 de agosto de 1960. A primeira passagem corresponde ao dia 5 de maio de 1960 e a última ao dia 21 de maio de 1961. As entradas de ambos os diários são sempre introduzidas com a data do dia, seguindo a risca a primeira definição do estudioso francês. A esta primeira característica da escrita diarística soma-se a destinação, o conteúdo e a forma do diário. De acordo com Lejeune, a forma do diário é livre: asserção, 
narrativa, lirismo, tudo é possível, assim como todos os níveis de linguagem e de estilo, dependendo se o diarista escreve apenas para ajudar na memória, ou com intenção de seduzir outra pessoa. Os únicos traços formais invariáveis resultam da definição proposta: a fragmentação e a repetição (Lejeune, 2008, p. 261).

E a destinação dos diários teria variado muito ao longo da história:

No início, os diários foram coletivos e públicos, antes de entrarem também na esfera privada, depois individual, e, enfim, na mais secreta individualidade. Digamos apenas que um diário serve sempre, no mínimo, para construir ou exercer a memória de seu autor (grupo ou indivíduo) (Lejeune, 2008, p. 261).

Tanto em Quarto de despejo quanto em Casa de Alvenaria a destinação é algo bastante aparente: por vezes, Carolina dialoga com o leitor no texto, deixando claro que a escrita diarística não se conjugava exclusivamente na escrita intimista, mas clamava pela instância do leitor. Esse ponto é um elemento a se considerar na observação de sua escritura permeada de intencionalidade literária, diretamente relacionada com a relação de reciprocidade entre autor e texto, pois autor e texto não existem separadamente: o texto pressupõe um autor, e o leitor, por sua vez, é componente fundamental da significação do texto. Nesse sentido, a escrita de si caroliniana buscava a existência do outro.

26 de julho de 1958: Dêi banho nas crianças e êles foram dêitar-se. E eu também tomei banho. É a primeira vez que eu escrevo que tomei banho. Voçes há de pensar que eu não gosto de agua (Citado por: Perpetua, 2000, p. 358).

27 de junho de 1958: ... Tem pessoas aqui na favela que diz que eu quero ser muita coisa porque não bebo pinga. Eu sou sozinha. Tenho três filhos. Se eu viciar no alcool os meus filhos não irá respeitar-me. Escrevendo isso estou cometendo uma tolice. Eu não tenho que dar satisfações a ninguem. Para concluir, eu não bebo porque não gosto, e acabou-se. Eu prefiro empregar o meu dinheiro em livros do que no álcool. Se você achar que eu estou agindo acertadamente, peço-te para dizer:

- Muito bem, Carolina! (Jesus, 1960, p. 73).

16 de outubro de 1958: ... Vocês já sabem que eu vou carregar água todos os dias. Agora eu vou modificar o inicio da narrativa diurna, isto é, o que ocorreu comigo durante o dia (Jesus, 1960, p. 121).

Dentro do quadro de características pensado por Lejeune para definir o gênero diário, junto à marcação do tempo e a destinação, o conteúdo é uma parte relevante. No caso de Casa de Alvenaria, este está assentado, no início do livro, em torno dos acontecimentos rotineiros da experiência de acesso restrito aos bens básicos de subsistência com a qual Carolina negociava constantemente. Porém, a fome e a falta de dinheiro se misturam com a expectativa para a assinatura do contrato com a editora Francisco Alves:

5 de maio de 1960. Levantei as 5 horas para preparar as roupas dos filhos para irmos na Livraria. Não vou fazer café porque não tenho dinheiro para o açucar nem dinheiro para o pão. Eu peguei um saco e catei latas, ferros e vidros e uns metais e 
fui vendê-los. Não tenho tido tempo de ver o senhor Manoel. Ganhei 22 cruzeiros. Comprei 12 de pão. O senhor Luiz Barbosa, que reside aqui perto da favela, deu-me lenhas. Eu disse-Ihe que hoje vou assinar o contrato com a Livraria Francisco Alves para editar meu livro. Êle disse-me que já me viu nos jornais e nas revistas e deu-me mais lenhas. Quando voltei peguei as lenhas e pus dentro do saco e voltei as pressas para a favela.

... O José Carlos entrou dizendo que estava com fome. Vamos prepararmos para irmos para a cidade. Vamos ver se o pai da Vera levou-Ihe o dinheiro no juiz. O João voltou da escola alegre por eu ter mandado pão para êle. Nós saímos. Passei no empório do Senhor Eduardo e pedi se êle me vendia uns sanduiches para os filhos. Não tinha pão. Só eu notei os olhares tristes dos meus filhos, porque sou mãe. Nós fomos para a cidade. Passamos para o mercado. A Vera olhava no solo para ver se encontrava algo para comer. Não encontrou nada. Começou a chorar e não queria andar. Eu disse-Ihe:

- Vamos no Juiz ver o dinheiro e eu compro algo para você.

Ela empacou-se. Dei-lhe uns tapas. Eu criticava as minhas ações, pensando: coitados! Além de estar com fome ainda apanham (Jesus, 1961, p. 13).

A assinatura do contrato é vista inicialmente pela autora como porta de entrada para a sua ascensão, mérito, para ela, atingido acima das condições sociais que a tornavam, como disse Joel Rufino dos Santos, uma "escritora improvável".

... Chegamos a Livraria Francisco Alves. Perguntei pelo escritor Paulo Dantas. A senhora que estava na caixa telefonou-Ihe. Êle viu-me lá do alto e deu ordem para eu ir de elevador. A livraria é alegre no aspecto. Ao entrar no elevador percebi que êle é antigo. Já deve ter uns 60 anos de uso. Dá a impressão que a livraria é uma relíquia de São Paulo. Eu aprecio o que é antigo.

Surgio o senhor Del Nero e cumprimentou-me. Surgio o senhor Lelio de Castro Andrade e o Senhor Paulo Dantas apresentou-me. Conversamos e eu fui perdendo o acanhamento e tinha a impressão de estar no céu. A minha côr preta não foi obstáculo para mim. E nem os meus trajes humildes (Jesus, 1961, p. 14. Ênfase minha).

A maior parte do texto de Casa de Alvenaria está assentada na narrativa da experiência da agora ex-favelada Carolina Maria de Jesus em seu auge de popularidade. Viagens da região sul a nordeste do Brasil, ao Uruguai e à Argentina, para dar palestras; idas a programas de televisão; entrevistas no rádio; participação em debates com políticos, artistas, universitários, militantes; festas com pessoas ilustres; eventos filantrópicos; estadias em hotéis. Em suma, uma agenda de compromissos novos que alteraram drasticamente sua rotina, completamente diversos dos que se desenrolavam na vida da autora anteriormente, como se lê em Quarto de despejo e Diário de Bitita. Com tamanho giro em seu cotidiano, a narradora desabafa em seu diário: "Eu estava exausta. Já estou saturada desses convites faustosos" (Jesus, 1961, p. 152). A mídia solicitava a opinião de Carolina para pautas e conjunturas políticas diversas, como mostra esta entrevista que ela transcreve no diário:

O Dr. Lelio de Castro Andrade nos recebeu amavelmente. Os reporteres entrevistoume. lam chegando livros para eu autografá-los. O jornalista é o senhor Carlos de Freitas. Aí vai a entrevista: 
Pergunta - Carolina, o que você acha e como se sente com a transformação de sua vida?

Resposta - Eu estou alegre e agradeço a colaboração dos que auxiliou-me na divulgação do meu livro. É o meu ideal concretizado.

P. - Que você acha da campanha eleitoral?

R. - Espero que o gôverno eleito colabore com o povo, porque os nossos politicos só interessa pelo povo nas campanhas eleitorais. Depois divorciam-se dos humildes.

P. - Que você acha do govêrno de Fidel Castro?

R. - Adoro o Fidel Castro. Êle faz bem defender Cuba. Os paises tem que ser independentes. Cada um deve mandar na sua casa.

P. - E se a senhora fôsse governador, o que faria?

R. - Queria dar impulso na lavoura, aproveitar as terras, construir casas com todo confôrto e colocar os favelados. Êles trabalhavam nas lavouras e teriam mais confôrto moral e físico. (Jesus, 1961, p. 37, 38).

Além da imensa repercussão de Quarto de despejo, a narradora de Casa de Alvenaria dedica longas passagens a contar os encontros e cruzamentos da autora com lideranças políticas, jornalistas e artistas negros. Conheceu, por exemplo, escritores como Solano Trindade e Oswaldo de Camargo:

Íamos para a casa do Correia Leite, na Estrada do Vergueiro. Quando chegamos na residência do Correia Leite relembrei dos tempos idos. Eu disse ao reporter que já o conhecia. Êle disse ao reporter que já conhecia-me da Rua Augusta. Fui bem recebida, com alegria de todos. Eu recebia uma homenagem dos pretos de São Paulo. Estavam presentes uns pretos do Rio de Janeiro. Serviram um almôço com discurso. Eu sentei na cabeceira da mesa. A comida estava deliciosa. Dava impressão de estar sonhando. Chegou os repórteres do "Diario da Noite". O "Delegado" fez discurso. Disse que havia de sair dos lixos e dos monturos quem ia libertar os homens de cor.

Não é preciso ser letrado para compreender que o custo de vida está nos oprimindo (Jesus, 1961, p. 41, 42).

Em Casa de Alvenaria a narradora reflete e analisa com mais vagar e cuidado a problemática dos conflitos raciais, do preconceito racial e da própria ascensão que estava vivendo. Embora seu ponto de vista se revele por vezes ambíguo, o convívio com a elite branca e com a elite negra possivelmente ampliara-Ihe o leque de observação:

O Eduardo Oliveira recebeu-me e disse: fico contente com a tua presença. É claro que devo aparecer nas festas dos pretos. Luiz Gama, não despresava os pretos. Henrique Oras, Jose do Patrocino o Ataulfo Alves. Quando o preto e intelectual procura proteger a classe (Jesus, 1996a, p. 218).

Fomos na redação. Eu ia olhando as bancas de jornais. As noticias sensacionais: Fiquei horrorizada com as perseguições na Africa. A Africa é terra dos pretos, mas os brancos foram para lá assambarcar o territorio dos coitados. Eu acho que a interferência do branco na vida do negro é só para atrapalhar. Deixa os coitados arrazados. Fiquei com dó do Patrice Lumumba, que podia viver mais uns dias. Quando será que a civilização vai predominar? (Jesus, 1961, p. 137) ${ }^{51}$.

\footnotetext{
${ }^{51}$ Patrice Lumumba foi um líder anticolonial e o primeiro-ministro, eleito em junho de 1960, na atual República Democrática do Congo depois de ter participado da conquista da independência do Congo Belga em relação à Bélgica.
} 
O céu está belíssimo. As nuvens estão vagueando-se. Umas negras, outras cor de cinza e outras claras. Em todos os recantos existe a fusão das cores. Será que as nuvens brancas pensam que são superior as nuvens negras? Se as nuvens chegassem até a terra iam ficar horrorizadas com as divergências de classe. Aqui na terra é assim: o preto quando quer predominar é morto. Podemos citar Patrice Lumumba (Jesus, 1961, p. 148).

Observe-se, por exemplo, a sutil diferença de tom tornada perceptível se lermos comparativamente a narrativa do dia 13 de maio, data histórica que Carolina sempre pontua e que atualiza em sua própria experiência. Em Quarto de Despejo, o "13 de maio" é data simpática e digna de comemoração, ratificando a versão da história oficial brasileira, para a qual tal data representaria a libertação dos negros escravizados. Mesmo assim, embora a autora manifeste a disparidade imensa existente entre brancos e negros - de modo a relacionar diretamente a "iluminação" dos brancos à felicidade dos negros - há o discernimento de que a abolição foi incompleta, posto que a fome que fustiga torna escravo aquele que a sofre:

13 de maio de 1958. Hoje amanheceu chovendo. É um dia simpático para mim. É o dia da Abolição. Dia em que comemoramos a libertação dos escravos.

... Nas prisões os negros eram os bodes expiatórios. Mas os brancos agora são mais cultos. E não nos trata com dêspreso. Que Deus ilumine os brancos para que os pretos sejam feliz.

Continua chovendo. E eu tenho só feijão e sal. A chuva está forte. Mesmo assim, mandei os meninos para a escola. Estou escrevendo até passar a chuva, para eu ir lá no senhor Manoel vender os ferros. Com o dinheiro dos ferros vou comprar arroz e linguiça. A chuva passou um pouco, vou sair.

... Eu tenho tanto dó dos meus filhos. Quando êles vê as coisas de comer eles brada:

- Viva a mamãe!

A manifestação agrada-me. Mas eu já perdi o hábito de sorrir. [...]

... Choveu, esfriou. É o inverno que chega. E no inverno a gente come mais. A Vera começou a pedir comida. E eu não tinha. Era a reprise do espetaculo. Eu estava com dois cruzeiros. Pretendia comprar um pouco de farinha para fazer um virado. Fui pedir um pouco de banha a Dona Alice. Ela deu-me banha e arroz. Era 9 horas da noite quando comemos.

E assim no dia 13 de maio de 1958 eu lutava contra a escravatura atual - a fome! (Jesus, 1960, p. 32).

Dois anos depois, a autora, a essa altura já personalidade pública, passara a compartilhar da vivência politizada da vanguarda artística e política afro-brasileira. Foi inclusive aplaudida pelo público ao subir no palco, a convite de Solano Trindade, na representação da peça "Rapsódia negra" ${ }^{52}$, encenada pelo Teatro Experimental do Negro em

\footnotetext{
52 Esta peça, de autoria de Abdias do Nascimento, cuja data da primeira montagem é 1952, trouxe aos palcos pela primeira vez duas grandes damas da arte brasileira: a dançarina Mercedes Batista e a atriz Léa Garcia. Os principais quadros da peça eram: África; Noturno em Harlem; Cuba; Imagen do Recife; Ritmos Haitianos; Candomblé e Leilão de Escravos.
} 
ocasião da data em que a Lei Áurea foi assinada. Notavelmente, em Casa de Alvenaria a narrativa do "13 de maio" apresenta um quadro mais problemático, pois traz mais acentuadamente a interseccionalidade de raça e classe no entendimento da condição dos negros. Com efeito, ao lado da positividade de se saber negra e gostar de ser negra, considerando "bonito estar satisfeito com o que somos", Carolina vê a cor negra dos barracos da favela e a negra existência dos favelados como algo negativo, repartindo o sentido do campo semântico "negro" a depender das condições de classe, pois para ela não é bonito e nem traz satisfação a negrura da favela.

13 de maio de 1960. Hoje é o dia que comemoramos a extinção da escravidão. Se a escravidão não fôsse extinta, eu era escrava, porque sou preta. (...) Fui telefonar para o reporter. Ele disse-me para eu encontrá-lo as 11 e meia. E convidou-me para eu ir com ele no Teatro da Escola de Medicina, que hoje comemora-se a data da abolição. Que o espetáculo é representado pelo Teatro Popular Brasileiro, dirigido pelo poeta Solano Trindade. (...) Preparei-me e saí para encontrar-me com o reporter na porta do "Diario da Noite". Eu não sabia que a Escola de Medicina tinha teatro. Quando chegamos, o teatro estava superlotado. Um espiquer veio fazer a descrição das cenas. O titulo da peça é "Rapsodia Afro-Brasileira". [...] O poeta Solano Trindade, apareceu no palco para falar sobre preconceito racial na Africa do Sul, e da condição dos pretos nos Estados Unidos. E disse que tinha uma visita para ser apresentada. E bradou:

- Carolina!

Galguei o palco e fui aplaudida.

... Depois do espetaculo fui apresentada para algumas pessoas que estavam na plateia e pediram autografos. Eu queria voltar de bonde, o reporter não permitiu e conduziu-me. Na rua Araguaia eu desci do carro e voltei para a favela. Era uma e meia da manhã. Eu estava pensando na festa comemorativa da Abolição da escravatura. Mas temos outra pior - a fome. Conversei com um preto que é artista e êle disse-me que gosta de ser preto. E eu também. Fiquei encantada com o preto João Batista Ferreira. É bonito estar satisfeito com o que somos. A favela estava calma. Não encontrei ninguém. A noite os barracões são todos negros. E negra é a existência dos favelados (Jesus, 1961, p. 20).

E finalmente, no dia 13 de maio de 1961, já colhendo os frutos da ampla circulação de Quarto de Despejo, Carolina escreve:

... Hoje é 13 de maio, dia consagrado aos pretos, que vivem tranquilos mesclados com os brancos. Hoje é um dia que nós os pretos do Brasil podemos bradar:

- Viva os brancos!

(Jesus, 1961, p. 177).

A reflexão implícita nesta narração demonstra a sutileza crítica de Carolina Maria de Jesus. Em primeiro lugar, a agudeza do entendimento de que o dia 13 de maio é data consagrada aos pretos que "vivem tranquilos mesclados com os brancos", estes, evidentemente não são os pretos com que a autora compartilhava as carências materiais no cotidiano da favela, pois a palavra 'tranquilidade' traz um léxico de sentimentos subjetivos e de conformidade social que estão ausentes na narrativa de Quarto de despejo, marcada 
prioritariamente pelo desassossego, pelo conflito e pela falta. O brado "viva os brancos" a ser expresso pelos pretos, pode indicar, num primeiro plano, sinal de alienação da autora. No entanto, tal exaltação é consoante à visão acentuadamente crítica da realidade histórica, posto que a data simbólica seja fajuta, visto não representar a Abolição de fato e tampouco a liberdade plena para os negros, que foram entregues à nova ordem social sem respaldo algum dos mecanismos de governo. Com efeito, é basilar ao protesto negro da primeira metade do século XX a reivindicação de uma "nova Abolição" ou de um abolicionismo de fato, entendendo que o primeiro fora feito pelos brancos e para os brancos (Fernandes, 1978, p. 103). Nesse sentido, bradar viva aos brancos em pleno 13 de maio pode ser lido como expressão de singular e fina ironia ${ }^{53}$.

A Casa de Alvenaria de Carolina estava assentada em alicerces frágeis e por isso mesmo foi experiência efêmera. "Eu ainda não habituei com este povo da sala de visitas uma sala que eu estou procurando um lugar para sentar" (Jesus, 1961, p. 66). Nesse diário podemos observar com mais frequência a complicada e oscilante relação de conflito e gratidão entre a escritora e o editor, que foi fundamental para que Carolina se tornasse uma autora reconhecida e que cuidou de seus rendimentos por um período, mas que ao mesmo tempo parecia a ela intrometer-se demasiadamente em suas decisões: "Fiquei furiosa com a atitude do Audálio, reprovando tudo, anulando meus progetos. Dá impressão de que sou sua escrava. Tem dia que eu adoro o Audálio, tem dia que eu xingo-o de tudo" (Jesus, 1961, p. 27).

A fome, embora ausente da vida concreta da autora na maior parte do período que cobre o diário, é presente constantemente na narrativa, através da memória dos tempos da vida na favela:

Fomos almoçar. Que comida gostosa. Que carne deliciosa. Sentada no restaurante chique, eu pensava nos infelizes que catam os restos de feira para comer. Tenho impressão que os infelizes que passam fome são meus filhos. Eu saí da favela. Tenho impressão que saí do mar e deixei meus irmãos afogando-se (Jesus, 1961, p. 86).

\footnotetext{
53 Em A Integração do negro na sociedade de classes, vol. II, Florestan Fernandes, analisando os Movimentos Sociais no "meio negro", pontua que "O 'negro' pretendia elevar-se à condição de 'raça' livre, autônoma e respeitada, projetando-se no processo histórico como agente de uma revolução social que abortara. Ele não retoma a ideologia do abolicionismo, construída pelos 'brancos' e para os 'brancos'. Elabora ele mesmo os seus mitos, avaliações e aspirações sociais, tentando dar à segunda Abolição o conteúdo de uma afirmação do 'negro' para o 'negro' dentro da ordem social estabelecida"' (Fernandes, 1978, p. 103).
} 
Diferente da interpretação de Dantas, para quem o sucesso havia "subido à cabeça" de Carolina, a lembrança dos tempos de miséria é recorrente inclusive em momentos de glamour, como num jantar em que ela participou junto a Jorge Amado, Zélia Gattai e Jurema Finamour e registrou no diário:

\footnotetext{
Pensei: se todos pudessem comer assim? Estamos na época em alguns comem e outros não. [...] A época do sofrimento deixa cicatriz na mente. Tem hora que relembro a voz angustiosa de Dona Maria Puerta, lá da favela:

- Estou com vontade de comer um pedacinho de carne.

Jamais hei de olvidar que existe fome (Jesus, 1961, p. 171).
}

Do ponto de vista formal, em Casa de Alvenaria a forma diarística é mais próxima ao que se espera do gênero se o compararmos com Quarto de Despejo, pois no primeiro há notavelmente mais espaço para a grafia de pensamentos e reflexões da autora, embora conservando marcas de oralidade; enquanto que no segundo a oralidade é mais presente, pois é mais comum a narração em forma de fala, trazendo diálogos inteiros em discurso direto. "Estes dias eu não estou escrevendo. Estou pensando, pensando. Quando escrevi contra os favelados fui apedrejada..." (Jesus, 1961, p. 83). A reflexão aparece em trechos como este, suprimido do diário publicado:

Aos que me agrada, eu agrado. Os que aborrece-me passa um mau bocado comigo. [...] Os brancos do Brasil ainda continuam escravizando os pretos. Uma escravidão Moral - Intimidando o preto com prisão. Sobretudo quando o preto érra e perde a fôrça Moral. Que eu procuro não errar para não ser dominada pelos brancos (Jesus, 1996a, p. 84).

O espaço autoral caroliniano, além de trazer para a superfície textual a experiência histórica de um outro sujeito social, diversa, como pontuamos, do sujeito tradicional do discurso autobiográfico, é constituído por uma índole estética que subjaz a escrita documental e lhe dá forma, em suma. Esta índole estética é perceptível na expressão poética que esbanja arranjos metafóricos e confere ao texto sua singularidade.

As metáforas são recurso recorrente, o que revela a capacidade da autora em manusear a linguagem não apenas com o intuito de representar algo, mas potencializando a linguagem em ato, ela mesma produtora de uma realidade nova, construída na criatividade artística que tangencia termos separados nos seus significados individuais para o nascimento de um novo sentido, único e inesperado:

Levantei as 4 horas para escrever e ler O Cruzeiro extra sobre Brasilia. A Brasilia é o vistido novo do Brasil (Citado por: Perpétua, 2000, p. 350). 
A coisa pior para mim, é conversar com uma pessoa depois de perder a simpatia. A Dona Theresinha para mim é igual o dia de hontem, que passou (Citado por: Perpétua, 2000, p. 350).

Oh! São Paulo rainha que ostenta vaidosa a tua coroa de ouro que são os arranhacéus. Que veste viludo e seda e calça meias de algodão que é a favela (Jesus, 1960, p. 42).

A noite está tépida. O céu já está salpicando de estrelas. Eu que sou exótica gostaria de recortar um pedaço do céu para fazer um vestido (Jesus, 1960, p. 30).

A plasticidade descritiva é característica da narrativa caroliniana, fazendo as imagens quase saltarem aos olhos de quem lê:

Levantei as 5 horas. A agua esta tão pouca que eu fiquei dessanimada. puis o balde para encher e fui escrever um pouquinho. É tão bom escrever de manhã. O silêncio é um bom coadjuvante para quem escreve. Abri a janela para ver se o balde estava chêio E perpassei o olhar pelo espaço. As estrêlas já estavam recluindo-se. O ceu esta azul claro. Acho maravilhoso a estrela d'alva. ela tem aureola e surge so no nascente. Com certêza ela é a rainha das estrêlas. Assim que o balde enchia eu ia retirá-lo. E assim enchi o barril. Fiz café e fui comprar pão (Citado por: Perpétua, 2000, p. 352).

Outro elemento característico da estética impressa nos diários pode ser depreendido nesse excerto, que, embora extenso, citamos abaixo na íntegra. Trata-se da multiplicidade de vozes presentes no texto, que o faz adquirir um caráter de pluridiscursividade. A pluridiscursividade é a própria formalização da experiência social cotidiana e já está presente enquanto recurso expressivo na composição de Quarto de despejo: como se diante da atividade de "catar" papel para prover o alimento diário, de "catar" espaços em branco nas folhas usadas que encontrava nas ruas, de "catar" alguns momentos de silêncio em meio ao barulho da favela, a autora "catasse" discursos e recursos expressivos para narrá-los. Aqui, Carolina Maria de Jesus, narradora e personagem do evento narrado, assegura, de forma potencial, o rompimento de qualquer possibilidade de hegemonia discursiva e, em consequência, deixa ver um discurso polifônico sobre a favela.

21 de maio... Preciso ir ao Teatro (...) Saí atrasada, tomei um carro. Quando cheguei no Teatro era 6 horas da tarde. (...) Circulei o meu olhar pela platéia, contemplando aquela gente bem nutrida, bem vestida. Ouvindo a palavra fome, abstrata para êles. Sentei ao lado do jovem Eduardo Suplicy Matarazzo. Que jovem amável! Olhava as cenas no palco e perguntava:

- Mas... êles vivem assim nas favelas?

- Pior do que isto. Isto é apenas uma miniatura das cenas reais da favela.

Um fotografo pediu-me para sentar-me ao lado da Deputada Conceição Santamaria para nos fotografar.

Quando findou o espetáculo a atriz Celia Biar saiu no palco anunciando o debate. Convidou o deputado Rogê Ferreira para presidir o debate. E nos convidou a subir no palco. Subimos. Eu, Solano Trindade, Conceição Santamaria, professor Angelo Simões Arruda, Deputado Cid Franco, Dona Edy Lima. 
Quem presidia o debate era o senhor Rogê Ferreira. Citou que o meu livro "Quarto de Despejo" é um retrato real das agruras que o pobre encontra atualmente.

Eu estava confusa naquêle nucleo. Percebi que a Dona Elite encara o problema da favela com vergonha. É uma mancha para o país. (...) O segundo orador foi o senhor Angelo Simões Arruda. Estava lendo o "Quarto de Despejo" e anotando o que lia. Disse que em São Paulo o povo trabalha nas fabricas, nas oficinas e não saem pelas ruas catando papel. Saem para um serviço digno que Ihe proporciona uma condição de vida decente.

Pensei:

- Se o homem de São Paulo levasse uma vida decente não fazia greve salarial.

... O professor Angelo Simões Arruda continuou dizendo que as pessoas indolentes não escolhem lugar para habitar. Vivem nas cloacas.

- Cloaca é mitorio - pensei.

Se os pobres reside nas margens dos rios é porque não recebeu instrução, não aprendeu oficio. (...) O professor Angelo Simões Arruda não mencionou a necessidade de abolir as favelas, que duplicam por êste Brasil afora.

A terceira oradora fui eu. Citei: fui residir na favela por necessidade. Com o decorrer dos tempos percebi que podia sair daquele meio. Era horroroso para mim presenciar as cenas rudes que desenrolava-se como se fôsse natural. (...) Os favelados são os colonos. Por ser expoliados pelos patrões abandonaram o campo. Encontram dificuldades na cidade, que só oferece conforto e decência aos que tem bons empregos. Êles não podem acompanhar a vida atualmente. Devido ao custo de vida são obrigados a recorrer ao lixo ou os restos da feira.

- Não adianta falar de fome com quem não passa fome.

Quando escrevi o meu diário não foi visando publicidade. É que eu chegava em casa, não tinha o que comer. Ficava revoltada interiormente e escrevia. Tinha impressão que estava contando as minhas magoas a alguem. E assim surgiu o "Quarto de Despejo".

Classifiquei a favela de quarto de despejo porque em 1948, quando o Dr. Prestes Maia começou a urbanizar a cidade de São Paulo, os pobres que habitavam os porões foram atirados ao relento.

O quarto orador foi o poeta negro Solano Trindade. Criticou a teatralização de Dona Edy Lima. Disse que ela não citou as agruras que o livro relata como depoimento do gravíssimo problema que são as favelas espalhadas pelo Brasil afora. (...) O publico, interferiu-se, ora aplaudindo, ora vaiando. O senhor Cavalheiro Lima, êsposo de Dona Edy Lima, interferiu aludindo que a Dona Edy não alterou o texto do livro. Conservou a linguagem simples na peça, relatando o meu desvelo pelos filhos, lutando para retirá-los daquele pardieiro.

O Solano Trindade prosseguio, repetindo o que a Ruth de Souza disse na peça:

- Quando uma criança passa fome é problema de todo o mundo.

Fico horrorizada vendo a fome debatida em assembleia. O deputado Cid Franco disse que passou fome e conhece as agruras que o livro relata. Que o regime capitalista é a causa das desigualdades de classe. A Dona Conceição Santamaria dizia:

- Êle pertence ao regime capitalista. Êle está metamorfoseando-se na frente do publico. Êle está de mãos dadas com o regime capitalista.

Que confusão para mim. Queria ouvir o deputado Cid Franco por causa a sua cultura. Êle não é banal. Não é politico de negociatas. Citou:

- Se existe favelas são criadas e alimentadas pelo regime capitalista, que suga a seiva da classe salarial para duplicar seus haveres.

- não apoiado - respondeu o Dr. Paulo Suplicy.

Um jovem na plateia disse que o Deputado Cid Franco errava aludindo ao regime capitalista o desajuste social. O Deputado Cid Franco disse:

- Tenho um filho de 18 anos que não teme a extinção do regime capitalista.

Foi aplaudido. Os estudantes interferiram. Eu pedia ao Deputado Rogê Ferreira que desse as palavras, porque os estudantes são os homens de amanhã. Os estudantes 
apuparam o deputado. Êle sentou-se, dizendo que nunca foi a favela pedir voto. Comentou:

- Não renego a peça. Renego o regime social que favorece um terço da população. Sei que o capitalismo renega a reforma social.

- Apoiado!

- Não apoiado!

... Com aquela confusão eu tinha a impressão que estava na favela. Todos falando ao mesmo tempo.

... A ultima a falar foi a Deputada Conceição. Iniciou dizendo que auxiliou os leprosos. Por seu intermedio os leprosos são curados.

Uma voz na plateia:

- Não estamos falando de politica. Estamos falando da favela.

- A Carolina disse que na favela existe muitas indolencias - argumentou Dona Conceição.

- E na Assembleia - uma voz no palco.

- Em 1944, quando eu percorria as favelas...

Naquela epoca era ditadura que predominava.

Uma voz na plateia:

- A senhora é bem madura, em?

Risos.

A Dona Conceição respondeu sem perturbar-se:

- Naquêle tempo não existia jovens mal educados igual a você. Eu represento uma maioria, os que votaram em mim. E você é uma unidade apagada.

Um japonês falava. Uma voz lenta que ficava indistinta entre as outras. Os demais estavam nervosos. Dava impressão que ia haver um conflito no teatro. Os estudantes apuparam a Dona Conceição.

... Quando saí do teatro encontrei o jovem Matarazzo e disse-lhe:

- Você viu que confusão?

Dona Filomena Matarazzo convidou-me para almoçar na sua residência.

Tomei um taxi e fui para a minha casa (Jesus, 1961, p. 180, 183).

O filósofo da linguagem Mikhail Bakhtin (1895-1975) lançou a ideia de polifonia sugerindo que a mesma colocava em jogo uma multiplicidade de vozes ideologicamente distintas, as quais resistiam ao discurso autoral. Manipulando bem o recurso ao marcar a alteridade discursiva, observamos a ironia com que a narradora posiciona-se em comparação aos que estavam presentes no teatro, oriundos de experiências diversas da sua em relação às condições materiais. "Circulei o meu olhar pela platéia, contemplando aquela gente bem nutrida, bem vestida. Ouvindo a palavra fome, abstrata para êles". A personagem situa-se numa espécie de arena, de onde pode avaliar a sua vivencia na favela de uma perspectiva macro: "Eu estava confusa naquêle nucleo. Percebi que a Dona Elite encara o problema da favela com vergonha. É uma mancha para o país". A narradora ouve e reflete sobre os pontos de vista colocados na discussão, discordando das "vozes" enunciativas no plano subjetivo do pensamento, que é formulado na escrita a partir da ironia, como em relação à fala do primeiro orador, ao qual ela reage discordando: "Pensei: - Se o homem de São Paulo levasse uma vida decente não fazia greve salarial". O plano da reflexão interna é preponderante, 
como na discordância com a fala do professor Angelo Simões Arruda, para quem "as pessoas indolentes não escolhem lugar para habitar. Vivem nas cloacas". Ao que parece, a voz da autora não é colocada na situação vivida, mas seu ponto de vista discordante se expande na palavra escrita: "Se os pobres reside nas margens dos rios é porque não recebeu instrução, não aprendeu oficio".

A estilística caroliniana pauta-se em ritmos breves, ligeiros, que parecem estar de acordo com o próprio ritmo dos seus dias, sempre buscando um espaço entre as horas para escrever, dando um compasso rápido à dança de suas palavras e lançando sentidos que insurgem pelo choque entre múltiplas matérias. O choque - ou a travessia - constante entre a palavra concreta e a palavra mais próxima ao lírico, posto que Carolina Maria de Jesus se entendesse poeta, dá forma à sua linguagem literária esteticamente compósita.

O céu é belo, digno de contemplar porque as nuvens vagueiam e formam paisagens
deslumbrantes. As brisas suaves perpassam conduzindo os perfumes das flores. E o
astro rei sempre pontual para despontar e recluir-se. As aves percorrem o espaço
demonstrando contentamento. A noite surge as estrelas cintilantes para adornar o
céu azul. Há varias coisas belas no mundo que não é possivel descrever. Só uma
coisa nos entristece: os preços, quando vamos fazer compras. Ofusca todas as
belezas que existe (Jesus, 1960, p. 44).

Com efeito, a narrativa cotidiana é permeada pelo trânsito constante entre elementos da experiência concreta e agenciamentos ficcionais que a direcionam para o campo mais abstrato. Desde o papel, matéria prima concreta que recebe a letra firme e se potencializa também em matéria prima de sua subjetividade, à dureza concreta do pão, de onde abstraise a projeção para a experiência também dura que abrange as condições materiais de vida dos favelados: "Duro é o pão que nós comemos. Dura é a cama que dormimos. Dura é a vida dos favelados" (Jesus, 1960, p. 42).

... Chegou o esquife, Côr roxa. Côr da amargura que envolve o coração dos favelados (Jesus, 1960, p. 34).

Eu durmi. E tive um sonho maravilhoso. Sonhei que eu era um anjo. Meu vestido era amplo. Mangas cor de rosa. Eu ia da terra para o céu. E pegava as estrelas na mão para contemplá-las. Conversar com as estrelas. Elas organisaram um espetaculo para homenagear-me. Dançavam ao meu redor e formavam um risco luminoso. Quando despertei pensei: eu sou tão pobre. Não posso ir num espetaculo, por isso Deus envia-me estes sonhos deslumbrantes para minh'alma dolorida. Ao Deus que me protege, envio os meus agradecimentos (Jesus, 1960, p. 117).

Fiz a comida. Achei bonito a gordura frigindo na panela. Que espetáculo deslumbrante! As crianças sorrindo e vendo a comida ferver nas panelas. Ainda mais quando é arroz e feijão, é um dia de festa para êles. (...) Quando puis a comida o João sorriu. Comeram e não aludiram a côr negra do feijão. Porque negra é a nossa vida. Negro é tudo que nos rodeia (Jesus, 1960, p. 43-44). 
Resolvi tomar uma media e comprar um pão. Que efeito surpreendente faz a comida no nosso organismo! Eu que antes de comer via o céu, as arvores, as aves tudo amarelo, depois que comi, tudo normalizou-se aos meus olhos (Jesus, 1960, p. 45).

Comecei sentir a boca amarga. Pensei: já não basta as amarguras da vida? (Jesus, 1960, p. 45).

Comprei um pão as 2 horas. É 5 horas, fui partir um pedaço o pão já está duro. 0 pão atual fez uma dupla com o coração dos políticos. Duro, diante do clamor publico (Jesus, 1960, p. 54).

Construída dentro dessas características estéticas, a narrativa de Casa de Alvenaria revela o sentimento de desilusão que Carolina Maria de Jesus adquiriu em relação à literatura, após a experiência que vivenciou com a popularidade angariada com Quarto de despejo. As entrevistas exaustivas, as fotografias, as viagens, os contratos de traduções e edições no exterior e o lucro em vendagens e com direitos autorais ocorriam sempre através da mediação de outras pessoas; isto é, afora a escrita, tudo que envolvia o universo da publicação de um livro não era protagonizado pela autora e sim por seus mediadores. Nos escritos na casa de alvenaria publicados em Meu Estranho Diário, Carolina manifesta seu descontentamento diante dessa situação:

Vou abandonar a literatura. Com as confusões que enfrento com o quarto de despejo, fui perdendo o amor pela literatura. (...) saímos da livraria eu fui quêixando que vou deixar a literatura de lado. Vou arranjar um emprego. Não me adapto a ser teleguiada. Com o dinheiro que recebo da Europa eu queria dar entrada noutra casa e alugar a que estou morando. Com o aluguel eu ia pagando as prestações da casa. Mas o dr. Lélio e o Audálio, interferiram - querem pagar a casa de uma vez e atrapalha os meus progetos. Avisei ao senhor Bertini, se eu não tiver dinheiro para comprar comida para os meus filhos eu não vou a Argentina Ele ouviu-me desinteressado. Pensei: ele ainda não me conhece. Não sabe que eu sou descendente da bomba atômica (Jesus, 1996a,p. 136, 137).

(...) Sentei e fiquei conversando com um pretinho que tem cavanhaque. Disse-lhe que o meu sonho e viver na minha terra, e abandonar a vida literária. Da muita confusão. Quando eu era da favela era despresada pelo povo. porque ninguem quer amisade com favelado. Dizem que são ladrões. Mas o que falta para o pobre é comida e carinho. Agora, tem tanta gente que bajula-me e aborreçe-me. O pretinho disse que os brancos querem dominar os pretos. Eu disse-lhe que não adimito que um branco domina-me não dêixo ninguem me por sela, nem frêio. Quero ser livre igual o sol (Jesus, 1961, p. 130, 131).

De fato, a publicação deste diário demarca o encerramento do período de sucesso de público e de exposição midiática que a autora vivenciava desde a primeira reportagem publicada por Audálio Dantas em 1958. Longe dos holofotes, realizado o desejo de adquirir 
um pedaço de terra para si, Carolina Maria de Jesus passa a dedicar-se à escrita de suas memórias de infância e juventude. 


\section{2 - "Um Brasil para os brasileiros" e A vida de Bitita}

Um dia apoderou-se de mim um desejo de escrever: Escrevi. - Carolina Maria de Jesus

A publicação de Diário de Bitita é devida à visita que Carolina Maria de Jesus recebeu de duas jornalistas francesas que foram entrevistá-la em seu sítio em Parelheiros. Em meados dos anos 1970 as jornalistas Clélia Pisa e Maryvonne Lapouge coletaram diversos depoimentos de mulheres envolvidas nas mais variadas atividades culturais para o livro "Brasileiras: voix, écrits du Brésil". Carolina entregou às jornalistas os manuscritos de seu último livro e elas tornaram-se responsáveis pelo trabalho de editoração e publicação, na coleção Téimognages (Testemunhos) da editora francesa Métaillé.

Em 1975 Maryvonne Lapouge e Clélia Pisa retornaram à França levando, junto com entrevistas gravadas, originais de duas escritoras, Clarice Lispector e Carolina Maria de Jesus. Conseguiram a publicação do livro da primeira pela Édition des Femmes. Quanto ao de Carolina, foi traduzido para o francês e denominado "diário", dado o sucesso que Quarto de despejo alcançara na França. Os títulos sugeridos pela autora eram Minha vida ou Um Brasil para os brasileiros (Castro \& Machado, 2007, p. 120).

Lançado primeiramente na França, em 1982, com o título Journal de Bitita, apenas em 1986 a Nova Fronteira comprou os direitos de edição e traduziu a obra para o português, sob o título Diário de Bitita. Os originais permanecem na França.

A classificação como "diário" tem mais a ver com estratégia editorial e de mercado do que com o gênero do texto. Diário de Bitita, apesar do título, apresenta-se sob os pressupostos formais da autobiografia. Há diferenças entre a autobiografia e o diário: a primeira constitui uma narrativa com começo meio e fim, pois o tempo é retrospectivo e a escrita se dedica a reconstruir um passado; a identidade do autobiografado não costuma estar em causa e a instância do leitor é de suma importância ao projeto. Já o diário apresentase como uma linha descontínua, uma página aberta, dedicada ao pormenor cotidiano; a narração é irregular, constituída por fragmentos autônomos que emolduram o sentimento de 
uma identidade pulverizada, por descobrir e inventariar; em vez do tempo retrospectivo da autobiografia, o tempo do diário é o devir, e a instância do leitor nem sempre é desejada.

Na edição brasileira o livro está catalogado como Ficção brasileira - Literatura brasileira - Romance, o que abre a discussão acerca dos limites entre os gêneros. Sabemos que toda autobiografia tem recursos ficcionais, pois o passado é reconstruído do ponto de vista do presente. Em Diário de Bitita pode-se falar de uma construção narrativa autobiográfica com conteúdos ficcionais, mas a consideração da obra como romance parece desconsiderar um elemento: a identidade de nome entre autor, personagem e narrador, que formaliza o pacto autobiográfico de Lejeune. Para o pesquisador, o fato do nome do personagem ser igual ao do autor já exclui de antemão a possibilidade da ficção: "ainda que, historicamente, seja completamente falsa, a narrativa será da ordem da mentira (que é uma categoria autobiográfica) e não da ficção" (Lejeune, 2008, p. 30).

Organizado em capítulos temáticos ${ }^{54}$, o livro segue uma progressão temporal que vai da infância rural da menina Bitita até sua juventude. Sob o título "Infância" o livro começa com a inserção espacial e social do grupo ao qual a autora pertence: "Os pobres moravam num terreno da Câmara: 'O Patrimônio'”. A família Jesus surge destacada desse coletivo, pois não morava no terreno que o poder público reservava aos destituídos de participação efetiva nas estruturas democráticas e sim numa casa que seu avô havia comprado:

Não tinha água. Mesmo furando o poço eles tinham que andar para carregar água. Nós morávamos num terreno que o vovô comprou do mestre, um professor que tinha uma escola particular. O preço do terreno foi cinquenta mil-réis. O vovô dizia que não queria morrer e deixar os seus filhos ao relento (Jesus, 1986, p. 7).

O acesso à propriedade privada é colocado já de início como meio garantido de segurança familiar, pois a preocupação do avô era assegurar a defesa de seus filhos após sua morte. No terceiro parágrafo do texto, a descrição da casa - tão importante para Carolina Maria de Jesus em sua trajetória inteira:

\begin{abstract}
A nossa casinha era recoberta de sapé. As paredes eram de adobe cobertas com capim. Todos os anos tinha que trocar o capim, porque apodrecia, e tinha que trocálo antes das chuvas. Minha mãe pagava dez mil-réis por uma carroça de capim. 0 chão era soalhado, era de terra dura, condensada de tanto pisar (Jesus, 1986, p. 7).
\end{abstract}

\footnotetext{
54 São eles: 1. Infância; 2. As madrinhas; 3. A festa; 4. Ser pobre; 5. Um pouco de história; 6. Os negros; 7. A família; 8. A cidade; 9. Meu genro; 10. A morte do avô; 11. A escola; 12. A fazenda; 13. Retorno à cidade; 14. Doméstica; 15. A doença; 16. A revolução; 17. As leis da hospitalidade; 18. A cultura; 19. O cofre; 20. Médium; 21. A patroa; 22. Ser cozinheira.
} 
Apenas no quarto parágrafo o texto memorialístico assume a primeira pessoa: "Eu estava fazendo a minha avant-première no mundo" e o primeiro rastro que nos é dado a conhecer desse sujeito que estreia no mundo é o questionamento acerca da sua paternidade: "E conhecia o pai do meu irmão e não conhecia o meu. Será que cada criança tem que ter um pai?" (Jesus, 1986, p. 7). Para logo na sequência trazer a figura marcante de seu avô:

O pai da minha mãe foi Benedito José da Silva. Sobrenome do Sinhô. Era um preto alto e calmo. Resignado com a sua condição de soldo da escravidão. Não sabia ler, mas era agradável no falar. Foi o preto mais bonito que já vi até hoje (Jesus, 1986, p. 7).

A construção das memórias exibe uma Carolina-menina curiosa, esperta e reflexiva: "Será que o céu é só onde estou vendo?"; ativa e determinada: "Eu era insuportável. Quando queria alguma coisa era capaz de chorar dia e noite até conseguir. Eu era persistente em todos os caprichos. Pensava que o importante é conseguir o que desejamos" (Jesus, 1986, p. $12,13)$ e ciosa de entender sua condição no mundo:

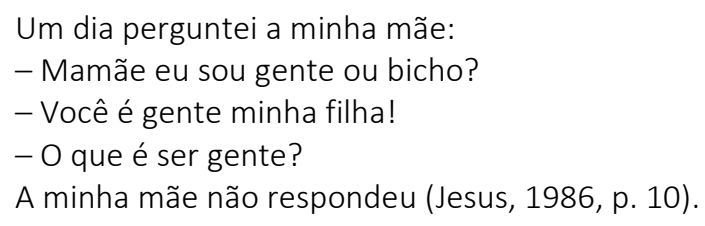

E de modificá-la, caso pudesse. Atenta às disparidades ante os papéis normativos de masculinidade e femilinidade, num mundo onde os atributos da força, da coragem e da vantagem se restringiam somente aos homens, Carolina Maria de Jesus declina da condição de "sexo frágil" aos quatro anos de idade:

No mato eu vi um homem cortar uma árvore. Fiquei com inveja e decidi ser homem para ter forças. Fui procurar a minha mãe e supliquei-lhe:

- Mamãe... eu quero virar homem. Não gosto de ser mulher! Vamos, mamãe! Faça eu virar homem!

[...] - Por que é que você quer virar homem?

- Quero ter a força que tem o homem. O homem pode cortar uma árvore com um machado. Quero ter a coragem que tem o homem. Ele anda nas matas e não tem medo de cobras. O homem que trabalha ganha mais dinheiro do que uma mulher $\mathrm{e}$ fica rico e pode comprar uma casa bonita para morar (Jesus, 1986, p. 10, 11 e 12).

Eu pensava: "as cruzes são de pau que os homens fazem. Que poder terão elas? Será que elas atendem os pedidos?" E eu pedi que fizesse eu virar homem. Queria plantar lavouras. Queria ser um homem forte e comprar um Ford. Queria ser igual ao José do Patrocínio, que ajudou a libertar os negros e ainda comprou um Ford (Jesus, 1986, p. 94).

A sequência dessa primeira parte do livro traz a relação de apadrinhamento, muito comum entre brancos e negros nos primeiros tempos da República, configurando, como aponta Roberto Schwarz, nossa estrutura de favor: 
A minha madrinha de batismo é quem me defendia. Ela era branca. Quando comprava um vestido para ela, comprava outro para mim. Penteava meus cabelos e beijava-me. Eu pensava que era importante porque a minha madrinha era branca (Jesus, 1986, p. 12).

Para encerrar a parte das memórias organizadas sob o título "Infância", a deflagração do estatuto de poeta em resposta à violência racialmente estruturada:

As vizinhas me olhavam e diziam:

- Que negrinha feia! Além de feia, antipática. Se ela fosse minha filha eu matava.

- Mãe não mata o filho. O que a mãe precisa ter é um estoque de paciência.

O senhor Eurípides Barsanulfo disse-me que ela é poetisa! (Jesus, 1986, p. 13).

Violência que aparece diversas vezes, em resposta, por exemplo, aos questionamentos filosóficos da criança Bitita, conforme as palavras da narradora:

- Mamãe! Mamãe... fala-me do mundo. O que quer dizer mundo?

Ela me deu dois tapas, saí correndo e chorando.

Minha tia Claudimira disse:

- Você precisa dar um jeito nesta negrinha. Ela vai te deixar louca (Jesus, 1986, p. 24).

Em Diário de Bitita ficamos sabendo com maiores detalhes da constituição familiar de Carolina, embora não exista a preocupação em mapear todos os segmentos e ramos familiares. Nascida numa família extensa, sua genealogia é matrifocal: nada se diz da família paterna. Filha de uma relação extraconjugal, as poucas informações sobre seu pai se resumem nesta passagem, em que se destaca o fato de que ele era um "poeta boêmio", traço que interessava à autora reclamar como herança congênita:

Com ampla liberdade, a minha mãe dançava e passeava as noites com os amigos, e foi ficando inebriada com as carícias dos seus amigos de bangulê. Foi nestes bailes inseletos que ela conheceu o meu pai. Dizem que era um preto bonito. Tocava violão e compunha versos de improviso. Era conhecido como o poeta boêmio. Nos bailes ele dançava só com a minha mãe. Ela teve um só filho com seu esposo, o Jerônimo Pereira. O sobrenome Pereira, do esposo de minha mãe, deve ter sido herdado de algum português, porque o esposo de minha mãe era mulato. Quando minha mãe ficou gestante, surgiram os disse-disse tão comuns nas cidades do interior. [...] Diziam que a criança que ia nascer era filha do poeta boêmio. Quando eu nasci, comprovaram-se os boatos [...]. A minha semelhança com o poeta serviu de pretexto para o esposo da minha mãe abandoná-la. Ele era um tipo de homem irresponsável, que não mantém o lar e exige fidelidade. Não tinha idade para ser chefe de família. O que ele queria era casar-se para conseguir a sua liberdade. Não teve consciência de minha mãe cuidando, zelando a sua felicidade. Disse:

- Casei com uma negra só para sair da tutela.

E foi morar com uma mulher branca. Uma velha de cinquenta e dois anos, poderia ser sua avó. Mas era branca. E ele dizia que mulher branca não tem idade.

- É sempre jovem.

Minha mãe ficou com dois filhos para manter. Minha mãe disse que bebeu inúmeros remédios para abortar-me, e não conseguiu. Por fim desistiu, e resolveu criar-me. Não fiquei triste, nem revoltada, talvez seria melhor não existir. Porque eu já estava compreendendo que o mundo não é a pétala da rosa. Há sempre algo a escravizá-lo (Jesus, 1986, p. 69, 70). 
A relação com o único irmão, da qual pouco se fala na composição das memórias, aparece mediada pela sensibilidade acerca das hierarquizações raciais: "Não sei se era ciúme, mas eu notava diferenças nos modos da mamãe nos tratar. O meu irmão era o predileto. Eu pensava: 'Ela trata-o com todo carinho, porque ele é mulato. E eu sou negrinha'” (Jesus, 1986, p. 81).

O avô materno de Carolina, Benedito José da Silva, é uma figura central e idealizada em suas memórias: "O vovô era descendente de africanos. Era filho da última remessa de negros que vieram num navio negreiro. Os negros cabindas, os mais bonitos e inteligentes" (Jesus, 1986, p. 114). Ele fora contemplado pela Lei do Ventre Livre e tivera oito filhos, quatro de cada sexo. Carolina de Jesus nada cita a respeito de sua avó materna, mas conta-nos de siá Maruca, a esposa de seu avô. A maior parte dos filhos de Benedito José da Silva casaram-se e tiveram muitos descendentes, criando-se uma enorme parentela negra na cidade de Sacramento. Sobre eles, como sobre a população em geral da cidade, o analfabetismo surge como um impeditivo da emancipação, de acordo com o que afirma a narradora:

Os negros, por não ter instrução, a vida era-lhes difícil. Quando conseguiam algum trabalho, era exaustivo. O meu avô, com setenta e três anos arrancava pedras para os pedreiros fazerem os alicerces das casas. [...] Os oito filhos do meu avô não sabiam ler. Trabalhavam nos labores rudimentares. O meu avô tinha desgosto porque os seus filhos não aprenderam a ler [...] É que na época que os seus filhos deveriam estudar não eram franqueadas as escolas para os negros (Jesus, 1986, p. 55-57).

O cenário social construído pela memorialística caroliniana é entremeado por agenciamentos ficcionais, como de resto é esperado do exercício memorialístico:

a suposta realidade/totalidade contada não passa de uma construção textual e que só pode ser compreendida como construção linguística de um Outro no presente, distanciado daquele "eu" real que supostamente teria vivido os fatos que pretende narrar (Barbosa, 2008, p. 144).

Mas, esta realidade textual converge com a situação real do negro no pós-abolição: "O meu avô era um vulto que saía da senzala alquebrado e desiludido, reconhecendo que havia trabalhado para enriquecer o seu sinhô português" (Jesus, 1986, p. 57).

A desagregação do regime escravocrata senhorial operou-se, no Brasil, sem que cercasse a destituição dos antigos agentes de trabalho escravo de assistência e garantias que os protegessem na transição para o sistema de trabalho livre. Os senhores foram eximidos da responsabilidade pela manutenção e segurança dos libertos, sem que o Estado, a Igreja ou qualquer outra instituição assumissem encargos especiais, que tivessem por objetivo prepará-los para o novo regime de organização da vida e do trabalho. O liberto viu-se convertido, sumária e abruptamente, em senhor de si mesmo, tornando-se responsável por sua pessoa e por seus dependentes, embora não dispusesse de meios materiais e morais para 
realizar essa proeza nos quadros de uma economia competitiva (Fernandes, 1978, p. 15).

A consciência revoltada ante tal situação de desamparo é posicionada nas memórias desde a infância da menina Bitita, embalada pelas histórias que ouvia de seu avô:

No mês de agosto, quando as noites eram mais quentes, nos agrupávamos ao redor
do vovô para ouvi-lo contar os horrores da escravidão. Falava dos Palmares, o
famoso quilombo onde os negros procuravam refúgio. O chefe era um negro
corajoso de nome Zumbi. Que pretendia libertar os pretos. Houve um decreto:
quem matasse o Zumbi ganharia duzentos mil-réis e um título nobre de barão. Mas
onde é que já se viu um homem que mata assalariado receber um título de nobreza!
[...] Os abolicionistas instigavam os negros a não obedecerem aos sinhôs. Mesmo
que eles quisessem fazer um levante estariam sós, não poderiam contar com a
cooperação dos seus escravos. Começaram a dar presentes aos escravos. Furavam
as orelhas das negrinhas, ofereciam-lhes brincos de ouro com a pretensão de
reconquistá-los. Mas já eram quase 400 anos de sofrimento (Jesus, 1986, p. 58).

O título originalmente dado por Carolina Maria de Jesus para o livro era "Um Brasil para os brasileiros" ou "Minha Vida". Os brasileiros, pela ótica do livro, é o povo, mais especificamente, são os afro-brasileiros pobres, pois além do enredo ser tecido a partir de estórias cujos protagonistas são negros, as opressões pautadas em preconceitos raciais permeiam toda a narrativa. Tanto a dimensão coletiva e generalizante do primeiro título, quanto o caráter singular e individual do segundo estão presentes no "diário", que se amplia em um duplo eixo narrativo. No primeiro eixo, observamos o foco narrativo estruturando um enredo que conta-nos estórias de certo tempo e de certo lugar nos interiores do país, a partir do ponto de vista de quem está afastado dos espaços de poder. As estruturas de poder surgem historicamente alimentadas pelas iniquidades raciais e os lugares sociais são racializados: "Quando havia um conflito, quem ia preso era o negro. E muitas vezes o negro estava apenas olhando. Os soldados não podiam prender os brancos, então prendiam os pretos. Ter uma pele branca era um escudo, um salvo-conduto" (Jesus, 1986, p. 52).

Os acontecimentos vão se deslindando para o leitor em torno das desigualdades, marca crônica que perpassa toda a narrativa. No contexto da República Velha, a substituição da mão de obra escrava deixara o negro sem lugar social na nova ordem. Na recriação memorialística, a narradora observa a conjuntura social desigual desde a escravidão que não foi abolida na prática à chegada dos imigrantes europeus, principalmente italianos.

O vovô já estava queixando-se que estava sentindo dores nos rins mas mesmo assim foi ouvir o senhor Manoel Nogueira. Ele nos dizia que os fazendeiros estavam desesperados, os italianos abandonavam as fazendas. Quando eles viram os colonos brancos desinteressarem-se das labutas rudes dos campos, iam nas cidades à procura de colonos. Não faziam questão de cor. Não selecionavam. Quantas promessas! Diziam aos negros: - Vocês podem ir para a minha fazenda. Eu mandei 
construir um salão de baile para vocês. Eu mando buscar o sanfoneiro Juritão Marangoni, para tocar para vocês dançarem. Mas os negros não iam porque na cidade também havia serviço, conseguiam muito pouco. E o senhor Nogueira dizia: Eles tiraram o São Benedito da lavoura e colocaram o são Genário. É a mania do brasileiro, tem o remédio no país, mas preferem importar da Europa. E as lavouras de café foram enfraquecendo-se. O último recurso foi os fazendeiros deixarem suas terras e estabelecerem-se nas cidades. Muitos deixaram suas terras chorando. - É o inicio do fim do Brasil, porque agora nós vamos para a cidade e vamos ser consumidores, será uma minoria que irá produzir para uma maioria consumir. Eles prometiam aos negros: - Voltem para a lavoura que nós vamos tratá-los bem. Aceitamos as suas reivindicações. A maioria dos negros eram analfabetos. Já haviam perdido a fé nos predominadores e em si próprios. O tráfico de negros iniciou-se no ano de 1515. Terminou no ano de 1888. Os negros foram escravizados durante 400 anos. Quando o negro envelhecia ia pedir esmola. Pedia esmola no campo. Os que podiam pedir esmolas na cidade eram só os mendigos oficializados. A Câmara dava uma chapa de metal com um número, depois de examinado pelo médico e ficar comprovada a sua invalidez. E o mendigo não podia emprestar dinheiro a juro. Eram fiscalizados. Um dia minha mãe estava lavando roupa. Pretendia lavá-la depressa para arranjar dinheiro e comprar comida para nós. Os policiais prenderam-na. Fiquei nervosa. Mas não podia dizer nada. Se reclamasse o soldado me batia com um chicote de borracha. E a notícia circulou. - A Cota foi presa. - Por que? Quando meu irmão soube que a mamãe estava presa começou a chorar. Rodávamos ao redor da cadeia chorando. A meia-noite resolveram soltá-la. Eu pensava: "É só as pretas que vão presas" (Jesus, 1986, p. 26).

E, aponta as consequências dessas engrenagens sociais e políticas na vida da personagem Bitita, cuja trajetória é organizada no enredo de modo a tornar coerente a Carolina do Quarto de despejo e depois. Este é o segundo eixo narrativo, que traz Bitita, personagem-narradora que narra sua experiência própria dessas desigualdades a partir de procedimentos fictícios.

Em suma, a autora constrói, em primeiro lugar, um foco narrativo formulado desde a perspectiva do não-lugar dos negros diante de um contexto rural em que as estruturas coloniais opressivas estavam em pleno funcionamento; e, junto a isso, elabora, em segundo lugar, a construção das memórias da menina Carolina Maria de Jesus, articulando o conteúdo de experiências centradas nessas estruturas opressivas à sua organização discursiva, construindo assim um eu reinventado, fabulizado.

Diário de Bitita é uma narrativa de memórias. Sua matéria é, portanto, o passado distante daquele que escreve. Como é comum ao gênero, "nas memórias, a narrativa da vida do autor é contaminada pela dos acontecimentos testemunhados que passam a ser privilegiados" (Melo Miranda, 1992, p. 36). Mas essas memórias são organizadas no enredo de modo a ecoar diretamente no presente daquele momento - após o reconhecimento público. E é aqui que os procedimentos fictícios funcionam na economia do texto. Carolina problematiza nessa obra a identidade imposta que a ela coube à época em que "apareceu" 
fraturando a harmonia da cidade. Dessa alteridade que ela queria afastar-se Carolina busca, seleciona e enfatiza aspectos positivos de sua formação para colocá-los em disputa com a imagem da escritora favelada, incoerente, deslumbrada com a fama, objeto nas mãos dos editores, aspectos constantemente reiterados pela mídia após a publicação de Casa de Alvenaria. O livro não tem prefácio e nenhuma apresentação, mas as obras Quarto de Despejo e Casa de Alvenaria são prólogos imediatos. Temos então uma obra que dialoga, internamente, com a imagem que foi criada exteriormente para a autora.

\begin{abstract}
Bitita convida-nos a seguir passo a passo o movimento do texto, que nos conduz ao entendimento mais profundo das causas, principalmente socioeconômicas, que levaram a autora àquela condição de vida, e a seu modo de enfrentá-los, descritos em seus diários. Paradoxalmente, na fragmentação que eles encenam, Carolina Maria de Jesus entrega-nos uma unidade constante e coerente que a inscreve e identifica. [...] Espécie de livro epílogo, fechando sua produção literária, revela feições mais fortes de um prefácio para a vida e para a obra de Carolina Maria de Jesus (Viana, 1995, p. 81).
\end{abstract}

A construção da personagem Bitita reitera traços característicos da Carolina Maria de Jesus dos outros livros, conformando uma linha de continuidade para este "eu" edificado na escrita. O processo de "outrizar-se", elaborando, na escrita das memórias construídas sobre a infância, uma Carolina que mesmo tendo outro nome já apresentava elementos da Carolina na maturidade, constitui o exercício de construir para si uma alteridade que sustenta sua identidade.

Um destes traços de continuidade é o domínio da palavra como arma de defesa: em uma passagem em que Bitita enfrenta o filho do juiz, que se apoiava no seu lugar de prestígio social e em sua branquitude para oprimir as meninas negras, assim ela narra a repercussão da briga:

Um dia, eu andava pelas ruas, ia contente. Ganhei uma lima ia oferecer à minha mãe quando apareceu o Humbertinho e me tomou a lima. Chorei. Ele era branco. Tinha servido no exército. Às vezes ele vestia a farda. Parecia o Rodolfo Valentino, era mais bonito. Quando eu encontrava-o, xingava: - Me dá a minha lima! Me dá a minha lima! Todos temiam-no. Ele era filho do juiz. E o juiz manda prender. Uma tarde quando eu passava na frente da sua casa ele abordou-me e me jogou várias limas no rosto, nas pernas. Que dor! Então eu xinguei: - Cachorro ordinário, ninguém aqui gosta de você! Vai embora, você é um sujo. Foram contar ao doutor Brand que foi ver a nossa discussão. Ele não compreendia porque aquelas limas estavam no chão espalhadas. Eu xingava: - Este ordinário vive pegando nos seios das meninas pobres, aperta e deixa elas chorando mas em mim você não vai encostar as suas mãos. O doutor Brand interferiu: - Você não tem educação? - Eu tenho. O teu filho é que não tem. - Cala a boca. Eu posso te internar. - Para o seu filho fazer porcaria em mim, como faz com as meninas que o senhor recolhe? É melhor ir para o inferno do que ir para sua casa. Foram avisar a minha mãe que eu estava brigando com o doutor Brand. Foram avisar os soldados. O povo corria para ver a briga. Quando o doutor caminhou na minha direção não corri e ele não me 
bateu. Minha mãe puxou-me: - Cala a boca cadela! Gritei: - Deixa, isto aqui é briga de homem com homem. Falei: - Olha doutor Brand, o seu filho me roubou uma lima. Todos têm medo dele. Eu não tenho! Ele não recebe convite para ir nas festas dos ricos porque os ricos não querem misturar-se com ele. - Cala a boca negrinha atrevida! - Atrevido é seu filho porque é filho de juiz, não respeita ninguém (Jesus, 1986, p. 28, 29).

Como último recurso para livrar-se de apanhar, Carolina lança sua flecha predileta: a palavra. Em consonância com o dito em Quarto de Despejo: "Não tenho força física, mas as minhas palavras ferem mais do que espada. E as feridas são incicatrisaveis" (Jesus, 1960, p. 49), a cena da briga se resolve quando a menina ataca o oponente utilizando-se do próprio poder deste, aquele de definir o que o outro é, dizendo ao branco o que o branco deve ser e acusando-Ihe da opressão que cometia apoiada no próprio lugar de poder racialmente estruturado em torno da branquitude:

Quando ele ia me bater, eu disse-lhe: - O Rui Barbosa falou que os brancos não
devem roubar, não devem matar. Não devem prevalecer porque é o branco que
predomina. A chave do mundo está nas mãos dos brancos, o branco tem que ser
superior para dar o exemplo. O branco tem que ser semelhante ao maestro na
orquestra. O branco tem que andar na linha. O doutor Brand, disse: - Vamos parar,
eu vou deixar sua cidade. Minha mãe pegou na minha mão e levou-me para casa. O
povo pedia: - Não bate nela (Jesus, 1986, p. 29).

Sustentando-se em Rui Barbosa, "Diziam que foram as palavras de Rui Barbosa, que mencionei, que fizeram o juiz retroceder. Que eu falava por intermédio de um espírito. É que eu ouvia o senhor Nogueira ler O Estado de São Paulo" (Jesus, 1986, p. 30) Bitita se destaca por saber ler. Assim, vai se revelando a estagnação sociocultural ao qual estava imersa a comunidade negra interiorana e ao mesmo tempo Bitita/Carolina vai se destacando dessa comunidade: "Quando me viam nas ruas, as pessoas sorriam para mim dizendo: - Que menina inteligente, nos defendeu! Limpou a cidade" (Jesus, 1986, p. 30).

Outro traço característico é a conviç̧ão de que sua condição de mulher não a inferioriza ou vitimiza em nenhum aspecto. Observamos, na construção da menina Bitita, a falta de reconhecimento com a figura de siá Maruca - esposa resignada de seu avô - devido à sua subalternidade quanto ao lugar de gênero. Apesar do respeito que a figura do avô inspira na narradora, há grande discordância quanto aos modos de tratamento machistas que este reservava para a esposa:

A siá Maruca não trabalhava. O vovô não permitia. Dizia:

- A mulher depois que casa deve cuidar apenas dos afazeres domésticos. Compete ao homem ser o chefe da casa.

[...] Um dia siá Maruca lavou roupa para fora e ganhou um mil-réis. Quando o vovô veio almoçar, não tinha farinha. Ele não comia sem farinha porque na época da 
escravidão os pretos eram obrigados a comer o angu, e a farinha. À tarde quando foi jantar encontrou farinha. Perguntou a siá Maruca:

- Onde e como conseguiste dinheiro para comprar esta farinha?

Os seus olhos voaram para o rosto da siá Maruca, que havia mordido os lábios. Por fim ela resolveu responder:

- Eu lavei as roupas da dona Faustina, ela pagou e eu comprei cinco quilos de farinha, lavei duas dúzias por um mil-réis. O quilo da farinha custou duzentos réis.

O meu avô retirou a cinta da cintura e espancou-a. dizia:

- É a última vez que a senhora vai fazer compras sem o meu consentimento. Quando quiser sair, peça-me permissão. Quem manda na senhora, sou eu! Se a senhora não sabe obedecer - vai embora!

A siá Maruca chorou.

E eu fiquei pensando: "É melhor ser meretriz, ela canta, vai aos bailes, viaja, sorri. Pode beijar os homens. Veste vestidos de seda, pode cortar os cabelos, pintar o rosto, andar nos carros de praça e não precisa obedecer a ninguém" (Jesus, 1986, p. $80,81)$.

Um terceiro elo entre o "eu" construído na infância e juventude e aquele da experiência na grande cidade, de que resultaram as narrativas de Quarto de despejo e Casa de Alvenaria, é a falta de tolerância e reprovação sistemática quanto aos vícios e o álcool em particular: "Os meus parentes bebiam pinga e ficavam embriagados. Brigavam, quebravam os móveis. Que suplício para quem não bebe permanecer no meio dos ébrios! Eu chorava porque queria ficar livre daquele ambiente" (Jesus, 1986, p. 80).

Em Diário de Bitita Carolina Maria de Jesus dedica páginas e páginas das memórias da primeira infância a pensar sobre as desigualdades raciais e o racismo, como demonstra as passagens selecionadas abaixo:

Eu sabia que era negra por causa dos meninos brancos. Quando brigavam comigo, diziam:

- Negrinha! Negrinha fedida! (Jesus, 1986, p. 92).

Então é você quem rouba as minhas frutas. Negra vagabunda. Negro não presta.

Respondi:

Os brancos também são ladrões porque roubaram os negros da África.

Ela olhou-me com nojo.

Imagina só se eu ia até a África para trazer vocês... Eu não gosto de macacos. Eu pensava que a África era a mãe dos pretos. Coitadinha da África que, chegando em casa, não encontrou os seus filhos. Deve ter chorado muito (Jesus, 1986, p. 55).

Eu estava com cinco anos, achava esquisito aquelas cenas antagônicas, a minha mentalidade embrionária não me auxiliava a compenetrar aquelas divergências. Se o negro passava cabisbaixo, o branco xingava!

- Negro, vagabundo! Eu não gosto desta raça! Eu tinha esta raça para o comércio. Eu pensava: "Meu Deus! Quem foi que começou essa questão, foi o preto ou foi o branco? Quem procurou o preto? Se foi o branco quem procurou o preto, ele não tem o direito de reclamar. O negro não invadiu suas terras, foram eles que invadiram as terras dos negros." Ninguém para me explicar. A minha mãe já estava saturada com as minhas perguntas (Jesus, 1986, p. 60). 
Nesse sentido, salta aos olhos o teor acentuadamente crítico quanto à dinâmica desigual das relações raciais e de gênero no contexto rural presentes em Diário de Bitita. Em suma, a realidade do racismo, da desigualdade socioeconômica, do machismo, do abuso de poder pelas autoridades, da ausência do Estado, etc., é tratada de maneira sensível e aguda e construída textualmente como parte das memórias da jovem Carolina - para tanto, basta recordar a citação anterior a respeito do tratamento dado às alunas negras nas escolas (Jesus, 1986, p. 39) ou, como vemos a seguir:

Tinha uma pretinha Isolina que sabia ler. Era solicitada para ler as receitas. Eu tinha uma inveja da Lina! E pensava: "Ah! Eu também vou aprender a ler se Deus quiser! Se ela é preta e aprendeu, por que é que eu não hei de aprender?" Ficava duvidando das minhas possibilidades porque os doutores de Coimbra diziam que os negros não tinham capacidade. Seria aquilo perseguição? Qual era o mal que os negros haviam feito aos portugueses? Por que é que eles nos odiavam, se os negros eram pobres e não podiam competir com eles em nada? Aquelas críticas eram complexos na mente do negro (Jesus, 1986, p. 43).

Os procedimentos fictícios funcionam no texto de modo a construir sentidos para a escritora Carolina Maria de Jesus, tornando suas escolhas coerentes e cabíveis. Constroem-se, por exemplo, os sentidos que resultaram na trajetória que a levou de Sacramento para a favela do Canindé. Na escrita ela reelabora este itinerário, organizando um enredo para sua vida. De fato, a promessa que a modernidade da metrópole representava se tornava utopia de liberdade e possibilidade de autonomia individual para Carolina:

Chorei pensando na quantidade de roupas que eu lavava e passava. Cuidar do quintal, olhar a casa quando ela estava ausente. Não roubava. Cuidava de tudo como se fosse meu. Decidi procurar outro emprego. Ou deixar o interior.

Pretendia encontrar um trabalho com melhor remuneração. Eu tinha que aprender a reagir, a exigir respeito nos contratos de trabalho. Mas não tinha casa e já estava cansando da minha vida andarilha.

A patroa era estrangeira, e eu nacional. Eu não podia competir com ela. Ela era rica, e eu pobre. Ela podia mandar prender-me. Continuei trabalhando.

A patroa sorria e dizia que tinha encontrado uma idiota que trabalhava quase de graça. Depois do jantar eu saía andando pela cidade, procurando emprego. Eu estava sã. Não havia obstáculo para vedar-me.

Indicaram-me uma professora que estava procurando uma criada para vir para São Paulo. Fui procurá-la, ela aceitou-me. Que alegria! Voltei correndo, fui preparar as minhas roupas. Não avisei a patroa que ia sair, ela já havia me despedido.

Até que enfim, eu ia conhecer a ínclita cidade de São Paulo! Eu trabalhava cantando, porque todas as pessoas que vão residir na capital do estado de São Paulo rejubilam como se fossem para o céu.

Quando cheguei à capital, gostei da cidade porque São Paulo é o eixo do Brasil. É a espinha dorsal do nosso país. Quantos políticos! Que cidade progressista. São Paulo deve ser o figurino para que este país se transforme num bom Brasil para os brasileiros (Jesus, 1986, p. 202, 203). 
Há no livro o agenciamento de vários discursos sociais para tratar da pobreza, o que confere à obra um estatuto de pluridiscursividade, mas isso apenas aprofunda a sensação de dificuldade em ultrapassar as desigualdades históricas, exposta no plano do conteúdo. De Rui Barbosa ao jornal Estado de São Paulo lido em voz alta pelo mulato Nogueira aos negros analfabetos, vai se criando um beco sem saída para a personagem (e para seu grupo), um não lugar, posteriormente ocupado pela utopia São Paulo cujo desfecho é o Quarto de despejo. Dessa forma, o leitor entende o lugar utópico projetado em São Paulo como a saída possível para Carolina.

Por eu ter tomado muitos remédios, minhas pernas estavam cicatrizando. Comecei a fazer projetos. 'Vou ficar boa. Hei de conhecer a cidade de São Paulo.' O povo dizia que era a cidade favo de mel. Em São Paulo tem um bairro que se chama Paraíso. E a cidade de São Paulo é um paraíso para os pobres. É o estado do Brasil que mais tem estradas de ferro (Jesus, 1986, p. 117).

Em Diário de Bitita lemos a engenhosidade literária com que Carolina Maria de Jesus desenhou sua trajetória da infância à juventude, empenhando recursos ficcionais elaborados. Por exemplo, a construção do narrador, que assume facetas diversas. O narrador-personagem posiciona os dramas coletivos narrados e os próprios da personagem-narradora de modo a ordenar um passado para Carolina, uma genealogia, um começo, que a diferencia da massa anônima dos que se desgarraram de suas terras de origem para se transformarem nos "migrantes favelados". Ao mesmo tempo, temos nessa narrativa de memórias um foco narrativo estruturado na opressão racial, que também é classista e patriarcal, desde um lugar onde as subjetividades não se completam, não formam cidadãos ou indivíduos plenos, pois as pessoas estão presas a uma sociedade de estruturas devastadoras. Isto, do ponto de vista da denúncia, deveria causar tanto furor quanto causou Quarto de despejo nos idos dos anos 60. 
CONSIDERAÇÕES FINAIS

É sabido que na década de 1960 o mundo passava por transformações sociais e culturais amplas que marcaram o século $X X$, as quais se podem lembrar através de eventos notáveis tais como a invenção da pílula anticoncepcional; o homem ter alcançado a lua; o surgimento do primeiro computador eletrônico; a construção do muro de Berlim. No Brasil, a TV Tupi faz a primeira transmissão em cores da televisão nacional; a capital do país foi transferida do Rio de Janeiro para Brasília, modificando definitivamente a configuração espacial do cerrado brasileiro; no final da década tem início o Tropicalismo.

O país passava por transformações agudas no plano político em decorrência da aceleração do processo de industrialização acentuada na década de 1950, cuja marca ficou sintetizada no famoso jargão do então presidente da república Juscelino Kubitschek: "avançar 50 anos em 5". A política econômica de JK incluía a substituição das importações, abrindo as portas do país para o investimento de capitais estrangeiros, o que assegurou a elevação dos índices de crescimento econômico e a instalação de diversas empresas multinacionais no país.

O período que abrange as décadas de 1950 e 1960 é comumente apontado, por estudiosos do processo de urbanização de São Paulo, como etapa decisiva na sua trajetória de cidade à metrópole (Meyer, 1991). Complexa e contraditória metrópole - celeiro do progresso para os mais otimistas, que (e)levaria o Brasil ao estatus de país desenvolvido:

O fato mais marcante e evidente da vida urbana paulistana no período de 19501960 é o crescimento. Dado essencial do processo de metropolização, este crescimento assume várias faces, manifestando-se em todos os aspectos da vida metropolitana, tornando-se o atributo preponderante e definidor dos demais. Forma e conteúdo da metrópole são diretamente determinados pelo crescimento. (...) Crescer deixou de ser naquele período um simples adjetivo assumindo feições de destino (Meyer, 1991, p. 25).

O desenvolvimento sempre almejado e completamente inconcluso marcou o destino de nossa modernização conservadora e, neste momento da história do país, a escritora Carolina Maria de Jesus tornou-se símbolo das contradições do projeto de modernidade nacional. O seu primeiro diário publicado, Quarto de Despejo, cobre principalmente os anos de 1958 e 1959. Inserida num contexto político de intensa crença na participação popular como instrumento de mudança social, Carolina rapidamente transformou-se em personalidade nacional: “A conjuntura política da época redimensionava a popularidade do 
diário, que passou a ser citado publicamente, pelas autoridades constituídas, em seus discursos sobre a necessidade de transformação econômica e social” (Perpétua, 2000, p. 48).

A indústria cultural tirou bastante proveito da desigualdade social estruturante do projeto desenvolvimentista moderno - no caso, o semianalfabetismo da mulher negra, as condições insalubres de moradia - e a transformou em mercadoria de consumo: uma espécie de Vênus Negra nacional. O sistema é inteligente: alimenta-se de suas próprias sobras. E autofagicamente macabro: marginaliza para incorporar, incorpora para marginalizar, mantendo sempre a desigualdade.

A valorização do texto como documento tinha um papel importante a cumprir: ante uma realidade tão perversa e violenta, ninguém poderia duvidar do testemunho do sobrevivente. Diz-se comumente que a vida imita a arte ou que a arte imita a vida. Mas quando o real parece inverossímil, quando o sobrevivente sobrevive porque narra, um vão entre o documentar o mundo e o construir a si se abre. Nessa fenda reside a obra caroliniana.

Obra que se quer artística, na qual o testemunho da história está entranhado. Mas desde quando a arte, para ser arte, precisa (ou pode) se desvencilhar da vida?

A escrita de Carolina Maria de Jesus atira aos leitores um tipo de experiência onde tudo é precário: o tempo, a cidade, as relações humanas, a política, as condições materiais. Se a elaboração estética é "falha", a falha não é defeito: é a forma possível dessa experiência, o que confere à obra a sua característica ímpar: a forma de narrar condiz com o narrado, e, portanto, mais relevante não são os procedimentos estéticos empreendidos na narrativa, mas de que maneira estão funcionando no texto e como respondem à matéria histórica. No caso dos diários, principalmente o uso de metáforas, o tom de oralidade, a plasticidade descritiva e a polifonia somam os recursos mais utilizados pela autora.

Manter-se viva em uma conjuntura institucional e social racista, patriarcal, elitista e classista e erigir uma obra centrada na escrita de si significa, em última análise, fazer-se sujeito diante de um mundo que a objetificava. Não apenas porque em Carolina Maria de Jesus a pobreza deixa de ser tema para tornar-se denúncia da ideia de progresso, mas porque a construção da própria subjetividade passa pela escrita. Porquanto, o caráter autobiográfico dos textos é legitimado na própria escritura e não na exterioridade, pois os índices de autoreferencialidade estão na camada interna do texto, que é metanarrativo: a escritora - a ideia de alguém que constrói uma narrativa - é uma dimensão do próprio texto. O "eu" construído na escrita é o "eu escritor" e a fronteira entre o que é vida e o que é escrita se rompe. 
Neste trabalho, procuramos relacionar cada capítulo ao outro conformando um todo analítico que correspondesse ao título da dissertação: "Os caminhos literários de Carolina Maria de Jesus: experiência marginal e construção estética". A experiência é o ingrediente principal da literatura desta brava mulher negra, mesmo quando se trata da escrita ficcional, como é o caso do romance Pedaços da Fome.

A margem de onde brota a experiência é política, pois Carolina Maria de Jesus viveu, como milhares, à margem das benesses que o desenvolvimentismo e o progresso traziam para o país, e mesmo quando passou a circular pelos espaços centrais citadinos, devido ao poder aquisitivo e à fama que conquistara, era mantida como "outro", como margem. A margem é social, pois sendo ela uma mulher negra de pouca escolaridade - no meio da intersecção de raça, gênero e classe - Carolina Maria de Jesus não passou ilesa pelas estruturas racistas de nossa sociedade. Ciente de que o poder tem cor, são dela as palavras: "Enfim, o mundo é como o branco quer. Eu não sou branca, não tenho nada com estas desorganizações" (Jesus, 1960, p. 70). A margem também é literária: se a autora angariou um sucesso editorial fantástico no início de seu percurso, isto remete à perversidade da indústria cultural, que como dissemos, a incorporou para marginalizá-la, e à curiosidade mórbida que a elite nutria sobre a miséria. Sendo margem, as dúvidas sobre sua escrita ser ou não literatura ainda reinam nos debates. A marginalidade literária também corresponde ao gênero dos escritos carolinianos: a escrita de si - diário, autobiografia e romance autobiográfico - são considerados gêneros "menores" para o cânone das letras. No Brasil, com exceção talvez para Pedro Nava, a escrita de si permanece como subliteratura.

A margem de onde brota a experiência caroliniana nada tem a ver com aquela que ficara conhecida pela frase de Oiticica: "seja marginal, seja herói". Para nossa autora, heróis são os que vivem até a hora da morte. Se a experiência autoral fala de um momento específico do tempo, sendo a escrita circunscrita contextualmente, a sua marginalidade permanece na contemporaneidade, por isso a leitura dos escritos de Carolina Maria de Jesus ainda hoje desafia, comove e encanta.

A experiência marginal é formalizada - no sentido de ganhar forma - no texto através do exercício estético. Carolina estetiza a si, cria para si identidade e alteridade, constrói um eu de palavras ou, constrói sua subjetividade na palavra, tornando-se autora, narradora e personagem de si mesma. 
Carolina Maria de Jesus escreve porque apenas o básico não é o suficiente para viver. Por isso, mais importante que tudo, era o seu ideal de poeta. Entre a luta incessante por mais um dia de sobrevivência - estando ela no espaço de semiescravidão onde vivera a infância e juventude; na favela do Canindé; na casa de alvenaria em Santana ou no sítio em Parelheiros - transgride as fronteiras do imponderável para afirmar-se e constituir-se humana. Sua arma: sua palavra. Que outra poderia caber-Ihe senão a literária? 
BIBLIOGRAFIA

- Obras de Carolina Maria de Jesus

1. JESUS, Carolina Maria de. Quarto de despejo: diário de uma favelada. São Paulo: Francisco Alves, 1960. Prefácio: DANTAS, Audálio. "Nossa irmã Carolina".

1. JESUS, Carolina Maria de. Quarto de despejo: diário de uma favelada. Rio de Janeiro: Ediouro, 1976.

2. JESUS, Carolina Maria de. Quarto de despejo: diário de uma favelada. Rio de Janeiro: Circulo do Livro, 1990.

3. JESUS, Carolina Maria de. Quarto de despejo: diário de uma favelada. São Paulo: Ática, 1993. Prefácio: DANTAS, Audálio. "A atualidade do mundo de Carolina".

4. JESUS, Carolina Maria de. Casa de Alvenaria: diário de uma ex-favelada. São Paulo: Francisco Alves, 1961. Prefácio: DANTAS, Audálio. "Casa de Alvenaria: História de uma ascensão social".

5. JESUS, Carolina Maria de. Pedaços da Fome. São Paulo: Áquila, 1963.

6. JESUS, Carolina Maria de. Diário de Bitita. Rio de Janeiro: Nova Fronteira, 1986.

7. JESUS, Carolina Maria de. Provérbios. São Paulo: Luzes, [196?]

8. JESUS, Carolina Maria de. Meu estranho diário. São Paulo: Xamã, 1996a. (Organizado por José Carlos Sebe Bom Meihy e Robert Levine).

9. JESUS, Carolina Maria de. Antologia Pessoal. Rio de Janeiro: UFRJ, 1996b. (Organizado por Meihy; revisado por Armando Freitas Filho).

10. JESUS, Carolina Maria de. Minha Vida. Prólogo. In: LEVINE, Robert; MEIHY, José Carlos Sebe Bom. Cinderela Negra: A Saga de Carolina de Jesus. Rio de Janeiro: UFRJ, 1994, p. 171-189.

11. JESUS, Carolina Maria de. O Sócrates Africano. In: LEVINE, Robert; MEIHY, José Carlos Sebe Bom. Cinderela Negra: A Saga de Carolina de Jesus. Rio de Janeiro: UFRJ, 1994, p. 190-196.

- Obras sobre Carolina Maria de Jesus

2. ANDRADE, Letícia Pereira de. O Diário como Utopia: Quarto de Despejo de Carolina Maria de Jesus. Dissertação de Mestrado, UFMS, 2008.

3. BAMISILE, Sunday Adetunji. Questões de gênero e da escrita no feminino na literatura africana contemporânea e da diáspora africana (Tese). Lisboa: Programa de Pós- 
graduação de Estudos de Literatura e Cultura e Estudos Comparatistas. Lisboa: Universidade de Lisboa, 2013.

4. CABRERA, Leonardo Piña. Calle y escritura como espacio y campo de acción. El testimonio de Carolina María de Jesús, mujer, negra y cartonera. In: Polis, Revista de la Universidad Bolivariana. Vol. 9, № 25, 2010, p. 487-513.

5. CASTRO, Eliana de Moura \& MACHADO, Marília Novais de Mata. Muito bem, Carolina! Biografia de Carolina Maria de Jesus. BH: C/Arte, 2007.

6. CORONEL, Luciana Paiva. Literatura de periferia e mercado: reflexões acerca do caso Carolina Maria de Jesus. Ipotesi, Juiz de Fora, v.15, №2, jul./dez. 2011, p. 63-71.

7. COSTA, Renata Jesus da. Subjetividades femininas. Mulheres negras sob o olhar de Maria Carolina de Jesus, Maria Conceição Evaristo e Paulina Chiziane. Dissertação. São Paulo: PUC, 2007.

8. DALCASTAGNÈ, Regina. A auto-representação de grupos marginalizados: tensões e estratégias na narrativa contemporânea. Letras de Hoje. Porto Alegre, v. 42, n. 4, p. 1831, dezembro 2007.

9. DANTAS, Audálio. O drama da favela escrito por uma favelada: Carolina Maria de Jesus faz um retrato sem retoques do mundo sórdido em que vive. Folha da Noite. São Paulo, ano XXXVII, N¹0.885. 9 maio de 1958.

10. DANTAS, Audálio. Retrato da favela no diário de Carolina. O Cruzeiro, Rio de Janeiro, № 36, p. 92-98, 20 jun. 1959.

11. DANTAS, Audálio. A atualidade do mundo de Carolina. In JESUS, Carolina Maria de. Quarto de despejo: diário de uma favelada. São Paulo: Ática, 1993.

12. FELINTO, Marilene. Clichês nascidos na favela. Caderno Mais. Folha de São Paulo. São Paulo: 29 de setembro de 1996. Arquivos Folha de São Paulo.

13. GODINHO, Marta T. O Serviço Social nas favelas - SP. Trabalho de Conclusão de Curso. São Paulo: Escola de Serviço Social, 1955.

14. LAJOLO, Marisa. A leitora no quarto dos fundos. Leitura: teoria e prática. Campinas, Mercado Aberto, ano 14, no 25, 1995.

15. LAJOLO, Marisa. "Poesia no quarto de despejo, ou um ramo de rosas para Carolina". In: Meihy (Org.) Antologia Pessoal, poemas de Carolina de Jesus. Rio de Janeiro: Ed. da UFRJ: 1996.

16. MACHADO, Marília Novais da Mata. Os escritos de Carolina Maria de Jesus: determinações e imaginário. Psicologia \& Sociedade; 18 (2), mai./ago. 2006, p. 105-110.

17. MAGNABOSCO, Maria Madalena. Reconstruindo imaginários femininos através dos testemunhos de Carolina Maria de Jesus: um estudo sobre gênero. Tese de doutorado não publicada, Programa de Doutorado em Literatura Comparada, FALE-UFMG, 2002.

18. MANFRINI, Bianca Ribeiro. A mulher e a cidade: imagem da modernidade brasileira em quatro escritoras paulistas. Dissertação. São Paulo: USP, 2008.

19. MARTINS, Wilson. Mistificação literária. Jornal do Brasil, 23 out. 1993. 
20. MEIHY, J. C. Sebe Bom \& LEVINE, Robert (Orgs.). Cinderela Negra: A Saga de Carolina de Jesus. Rio de Janeiro: UFRJ, 1994.

21. MEIHY, José Carlos Sebe Bom. Carolina Maria de Jesus: emblema do silêncio. São Paulo: Revista USP №. 37, maio 1998. Disponível em: <http://www.usp.br/revistausp/37/08josecarlos.pdf> Acesso em 12/05/2013.

22. MEIHY, José Carlos Sebe Bom. Subversão pelo sonho: a censura cultural nos diários de Carolina Maria de Jesus. IN: CARNEIRO, Maria Luiza Tucci.(Org.) Minorias Silenciadas História da censura no Brasil. SP: Edusp/ Imprensa Oficial do Estado/ Fapesp, 2002.

23. MEIHY, José Carlos Sebe Bom. O inventário de uma certa poetisa. In: JESUS, Carolina Maria de. Antologia Pessoal. Rio de Janeiro: UFRJ, 1996b. (Organizado por Meihy; revisado por Armando Freitas Filho).

24. OLIVEIRA, Eduardo de. Apresentação. In: Jesus, Carolina Maria de. Pedaços da Fome. São Paulo: Editora Áquila Ltda, 1963.

25. OLIVEIRA, Erica Cristina de. De Quarto de Despejo a Le dépotoir, o processo de refração na reescrita do diário de Carolina Maria de Jesus. Dissertação. São Paulo: USP, 2012.

26. PERPÉTUA, Elzira Divina. Traços de Carolina Maria de Jesus: gênese, tradução e recepção de Quarto de Despejo. Tese de doutorado não publicada, Programa de Doutorado em Literatura Comparada, Faculdade de Letras da UFMG: 2000.

27. PERPÉTUA, Elzira Divina. Produção e recepção do Quarto de despejo de Carolina Maria de Jesus: relações publicitárias, contextuais e editoriais. Revista Em tese. Belo Horizonte, vol. 5, 2002.

28. PERPÉTUA, Elzira Divina. Aquém do Quarto de despejo: a palavra de Carolina Maria de Jesus nos manuscritos de seu diário. Estudos de Literatura Brasileira Contemporânea, no 22. Brasília, janeiro/junho de 2003, p. 63-83.

29. RIBEIRO, Esmeralda. A narrativa feminina publicada nos Cadernos Negros sai do quarto de despejo. In: DUARTE, Eduardo e DUARTE, Constância (Org.). Gênero e representação na Literatura Brasileira. Vol. II. Belo Horizonte: UFMG, 2002.

30. ROCHA, Fernando de Sousa. Tudo cato: as formas do circular no diário Quarto de despejo, de Carolina Maria de Jesus. ArtCultura, Uberlândia, v. 13, № 23, jul/dez. 2011, p. 167-178.

31. SANTOS, Joel Rufino dos. Carolina Maria de Jesus: uma escritora improvável. Rio de Janeiro: Garamond, 2009.

32. SILVA, José Carlos Gomes da. Carolina Maria de Jesus e os discursos da negritude: literatura afro-brasileira, jornais negros e vozes marginalizadas. História \& Perspectivas, Uberlândia. № 39, jul. dez. 2008, p. 59-88.

33. SILVA, Mário Augusto Medeiros da. A descoberta do insólito: Literatura Negra e Literatura Periférica no Brasil (1960-2000). Tese de doutorado defendida no Departamento de Sociologia da UNICAMP, 2011.

34. SILVA, Mário Augusto Medeiros da. O povo e a cena histórica: Quarto de despejo e A integração do negro na sociedade de classes (1960-1964). Cadernos Cedec № 97, São Paulo: Cedec, jul. 2011. 
35. SILVA, Vera Regina Rodrigues da. Sob os olhos de Carolina: desigualdades, raça e território na cidade de São Paulo. In: Congresso da LASA - Associação de estudos latinoamericanos. Anais. Rio de janeiro, 2009.

36. SURIAN, Thais. Um estudo das práticas da escrita de mulheres (escritoras ou não). São Paulo: UNESP, 2009.

37. TOLEDO, Christiane Vieira Soares. O estudo da escrita de si nos diários de Carolina Maria de Jesus: a célebre desconhecida da literatura brasileira. Dissertação. Rio Grande do Sul: PUC, 2011.

38. XAVIER, Elódia. O corpo a corpo na literatura brasileira: a representação do corpo nas narrativas de autoria feminina. In: Refazendo nós: ensaios sobre mulher e literatura. Florianópolis: Editora Mulheres, 2003. Artigo Disponível em: <http://www.amulhernaliteratura.ufsc.br/artigo elodia.htm>. Acesso: 20/10/2011.

- Obras gerais:

1. ABDALA JR, Benjamin. Necessidade e solidariedade nos estudos de literatura comparada. In: Revista Brasileira de Literatura Comparada N. 3. ABRALIC. Rio de Janeiro, 1996. Disponível em: <http://www.abralic.org.br/download/revista/Revista_Brasileira_de_Literatura_Compara da_03.pdf>. Acesso: 11/03/2012.

2. ANDREWS, George R. Negros e brancos em São Paulo (1888-1988). São Paulo: EDUSC, 1998.

3. AVELAR, Idelber. Cânone Literário e Valor estético: notas sobre um debate de nosso tempo. Revista Brasileira de Literatura Comparada. № 15, 2009.

4. BASTIDE, Roger. A imprensa negra do estado de São Paulo. In: Bastide, R. Estudos Afrobrasileiros. São Paulo: Perspectiva, 1973.

5. BARTHES, Roland. Crítica e verdade. Trad. de Leyla Perrone-Moisés. São Paulo: Perspectiva, 1999.

6. BARTHES, Roland. O rumor da língua. Trad. Mario Laranjeira. São Paulo: Brasiliense, 1988.

7. BERND, Zilá. Negritude e literatura na América Latina. Porto Alegre: Mercado Aberto, 1987.

8. BERND, Zilá (org.). Poesia negra brasileira. Antologia. Porto Alegre: AEG Editora, 1992.

9. BERND, Zilá (org.). Antologia de poesia afro-brasileira. 150 anos de consciência negra no Brasil. Belo Horizonte: Mazza edições, 2011.

10. BOLLE, Willi. Fisiognomia da metrópole moderna: representação da História em Walter Benjamin. 2.ed. São Paulo: EDUSP, 2000.

11. BOSI, Ecléa. Memória e Sociedade: Lembranças de Velhos. São Paulo: Companhia das Letras, 1999.

12. BRAH, Avtar. Diferença, Diversidade, Diferenciação. In: Cadernos Pagu (26), Núcleo de 
Estudos de Gênero - Pagu/Unicamp, 2006.

13. CANDIDO, Antônio. Literatura e Sociedade. Rio de Janeiro: Ouro sobre azul, 2006.

14. CANDIDO, Antonio. Os olhos, a barca, e o espelho. In: Educação pela noite e outros ensaios. 3a edição, Ed. Ática, SP: 2003.

15. CANDIDO, Antonio. Poesia e ficção na autobiografia. In: Educação pela noite e outros ensaios. 3a edição, Ed. Ática, SP: 2003.

16. CANDIDO, Antonio. Poesia, documento e história. In: Brigada Ligeira e outros escritos. São Paulo: UNESP, 1992.

17. CAMARGO, Oswaldo de. O negro escrito. Apontamentos sobre a presença do negro na Literatura Brasileira. São Paulo: Secretaria de Estado da Cultura, Imprensa Oficial. 1987.

18. CARNEIRO, Sueli. Em legítima defesa. 2005. Fonte: http://www.geledes.org.br. Acesso em $13 / 09 / 2012$

19. COSTA, Sérgio. Dois Atlânticos. Teoria social, anti-racismo, cosmopolitismo. Editora da UFMG, 2006.

20. CUTI. Literatura negro-brasileira. São Paulo: Selo Negro edições, 2010.

21. DALCASTAGNÈ, Regina. Entre fronteiras e cercado de armadilhas. Problemas da representação na narrativa contemporânea brasileira. Editora UNB: 2005.

22. DALCASTAGNÈ, Regina. Uma voz ao sol: representação e legitimidade na narrativa brasileira contemporânea. Estudos de Literatura Brasileira Contemporânea, № 20. Brasília, julho/agosto de 2002.

23. DAMIÃO, Carla Milani. Sobre o declínio da "sinceridade". Filosofia e autobiografia de Jean-Jacques Rousseau a Walter Benjamin. São Paulo: Edições Loyola, 2006.

24. DANTAS, Audálio. O circo do desespero: coleção de reportagens. São Paulo: editora Símbolo, 1976.

25. DUARTE, Eduardo de Assis \& FONSECA, Maria Nazareth Soares. (Orgs). Literatura e Afrodescendência no Brasil: antologia crítica. Volume 4: História, teoria, polêmica. Editora UFMG, 2011.

26. EVARISTO, Conceição. Da grafia-desenho de minha mãe, um dos lugares de nascimento de minha escrita. In: ALEXANDRE, Marcos Antônio (Org.) Representações performáticas brasileiras: teorias, práticas e suas interfaces. Belo Horizonte: Mazza, 2007.

27. FERREIRA, Lígia Fonseca. "Negritude", "Negridade", "Negrícia": história e sentidos de três conceitos viajantes. Revista Via Atlântica № 9, Jun/ 2006. 
28. FERRÉZ. Manifesto de abertura: Literatura Marginal. In: Caros Amigos (Suplemento Literário) Literatura Marginal: a cultura da periferia: Ato I. São Paulo: 2001.

29. FERRÉZ. Literatura marginal: talentos da escrita periférica. São Paulo: Agir, 2005.

30. FERNANDES, Florestan. A integração do negro na sociedade de classes. São Paulo: Ática, 1978.

31. FERNANDES, Ronaldo Costa e LIMA, Rogério (Orgs.). O imaginário da cidade. Brasília: Editora Universidade de Brasília; São Paulo: Imprensa Oficial do Estado, 2000.

32. FONSECA, Maria Nazareth Soares. Literatura negra, literatura afro-brasileira. Como responder à polêmica? In: SOUZA, Florentina \& LIMA, Maria Nazaré (Orgs.). Literatura Afro-brasileira. Brasília: Fundação Cultural Palmares, 2006.

33. GONÇALVES, L. A. Negros e educação no Brasil. In: LOPES, E. M. et al. 500 anos de Educação no Brasil. Belo Horizonte: Autêntica,2000, p. 325-346.

34. GONZALEZ, Lélia \& HASENBALG, Carlos. Lugar de Negro. Rio de Janeiro: Marco zero, 1982.

35. HARVEY, David. A condição pós-moderna - uma pesquisa sobre as origens da mudança cultural. 3a edição. Trad. Adail Ubirajara Sobral e Maria Stela Gonçalves. São Paulo: Loyola, 1993.

36. HOLLANDA. Heloísa Buarque de. Impressões de Viagem: CPC, Vanguarda e desbunde. 1960/1970. Rio de Janeiro: Aeroplano. 2004.

37. LEITE, José Correia \& CUTI. ...E disse o velho militante José Correia Leite. São Paulo: Secretaria Municipal da Cultura, 1992.

38. LEJEUNE, Philippe. O pacto autobiográfico. De Rousseau a internet. Belo Horizonte: Ed. UFMG, 2008.

39. LISPECTOR, Clarice. A hora da estrela. Rio de Janeiro: Rocco, 1999.

40. MAIO, Marcos Chor. A História do Projeto UNESCO: Estudos Raciais e Ciências Sociais no Brasil, Tese de doutorado, Rio de Janeiro: IUPERJ, 1997.

41. MAIO, Marcos Chor. O projeto UNESCO: Ciências sociais e o "credo racial brasileiro". São Paulo: Revista USP, no 46, junho/agosto, 2000.

42. MELO MIRANDA, Wander. Corpos Escritos. São Paulo: Editora Edusp e Belo Horizonte: Editora UFMG, 1992.

43. MEYER, Regina Maria Prosperi. Metrópole e Urbanismo São Paulo anos 50. Tese de doutorado. São Paulo: Faculdade de Arquitetura e Urbanismo, USP, 1991.

44. MOTT, Luiz. Rosa Egipcíaca: Uma Santa Africana no Brasil. Rio de Janeiro: Bertrand Brasil, 1993.

45. NASCIMENTO, Érica Peçanha do. "Literatura marginal": Os escritores da periferia entram em cena. Dissertação de mestrado. Departamento de Antropologia social, Universidade de São Paulo, 2006.

46. PAIVA, V. Um século de educação republicana. Pró-Posições, Campinas, v. 1, n. 2, p. 7-21, jul. 1990. 
47. PAULINO, Jorge. O pensamento sobre a favela em São Paulo: uma história concisa das favelas paulistanas. Dissertação de Mestrado. São Paulo: FAU-USP, 2007.

48. PEREIRA, Carlos A. M. Retrato de Época: Poesia Marginal Anos 70. Rio de Janeiro: FUNARTE, 1981.

49. PEREIRA, Julio César. Sancas e Marimbas: A Saga do Terreirão. Sacramento-MG: Editora PrismaGraf, 2008.

50. PERRONE-MOISÉS, Leyla. Altas literaturas: Escolha e valor na obra crítica de escritores modernos. São Paulo: Cia. das Letras, 2003.

51. PINTO, Ana Flávia Magalhães. De pele escura e tinta preta: A imprensa negra do século XIX (1833-1899). Dissertação de mestrado. Departamento de História, Universidade de Brasília, 2006.

52. PINTO, R. P. A. Movimento negro em São Paulo: luta e identidade. Tese de Doutorado, São Paulo: FFCH/USP. 1994.

53. QUEIROZ, Vera. "Linhas de força femininas no cânone literário brasileiro". In BRANDÃO, Izabel (Org.). Boletim do GT A Mulher e Literatura, Vol. VIII, ANPOLL. UFA, maio de 2000.

54. REIS, Maria Firmina dos. Úrsula. (1859). Minas Gerais: Editora Mulheres - PUC/MG, 2004.

55. SCHWARZ, Roberto. Ao vencedor as batatas. Forma literária e processo social nos inícios do romance brasileiro. SP: Ed. 34, 2000.

56. SCHWARZ, Roberto (Org.). Os pobres na Literatura Brasileira. São Paulo: Brasiliense, 1983.

57. SCHWARZ, Roberto. Sequências brasileiras. São Paulo: Companhia das Letras, 1999.

58. SCHWARCZ, Lilia Moritz. Gilberto Freire: adaptação, mestiçagem, trópicos e privacidade em "Novo Mundo nos trópicos". IFCH - UFRGS: Mal-estar na Cultura. Novembro, 2010.

59. SEVCENKO, Nicolau. A capital irradiante: técnica, ritmos e ritos do Rio. In. SEVCENKO, Nicolau et al. História da vida privada no Brasil. Vol. 3. São Paulo: Companhia das Letras, 1998.

60. SIMMEL, Georg. A metrópole e a vida mental. In. VELHO, Otávio Guilherme. (Org.) O fenômeno urbano. São Paulo: Zahar, 1979.

61. SPIVAK, "Can the Subaltern Speak?". IN: Cary Nelson \& Lawrence Grossberg (Orgs). Marxism and the Interpretation of Culture. Macmillan: 1988.

62. SPIVAK, Gayatri Chakravorty. Pode o subalterno falar? 1a ed. Trad. Sandra Regina Goulart Almeida; Marcos Pereira Feitosa; André Pereira. Belo Horizonte: Editora da UFMG, 2010.

63. TEREZA, Maria. Negrices em Flor. SP: Edições Toró, 2007.

64. TRINDADE, Solano. Canto negro. São Paulo: Nova Alexandria, 2006.

65. VIANA, Maria José Motta. Do sótão à vitrine: Memórias de mulheres. Belo Horizonte: UFMG, 1995.

66. WILLIAMS, Raymond. O campo e a cidade na história e na literatura. Trad. Paulo Henriques Britto. São Paulo: Companhia das Letras, 1989. 
